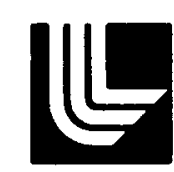

LAWRENCE LMERMORE LABORATORY University of Callomia/Livermore, Callomia/94550

\title{
UCRL-51926 \\ PRESENT STATUS AND FUTURE PROSPECTS FOR NONELECTRICAL USES OF GEOTHERMAL RESOURCES
}

J. H. Howard, Editor

MS. date: October 3, 1975

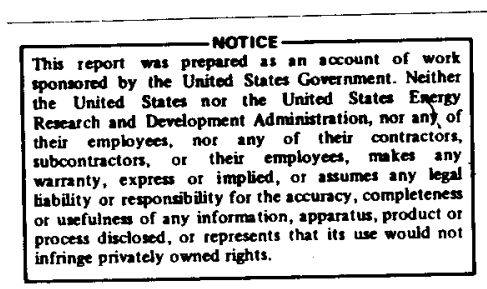




\section{Preface}

The purpose of this report is

to systematize and disseminate information about the non-electrical

applications of geothermal resources:

Planning for this report started in

October, 1973, at a meeting which led to the organization of a Geothermal

Pilot Study for the NATO Committee on the Challenges of Modern Society

(CCMS). Should this report serve as a useful introduction to the uninitiated, and should it be useful in directing an interested observer in a productive way, it will have served its purpose.

The following members of the cciMs Geothermal Pilot Study's Wồ̃ ing Subcommittee on Nonelectrical Uses of Geothermal Resources contributed to the writing and organization of this report:

J.H. Howard, Editor of the Report and Chatrman of the Subcommittee
A. Alcarez

S. Alpan

E. Barbier

C.C. Barton

J.C. Bresee
G.E. Brandvōid

G. Bodvarsson

L. Boersma

J.J. Cohen

N.B. Crow

G. Delísle

M. Faneli1

S.A. Gitterman

J. Guiza

F.A. Harris

F.S.M. Hodsol1

A.M. Jessop

o. Kappelmeyer

E."Krieps

J.F. Künze W.A.J. Mahon

B.C Marshail

A.S. Mendès

W.E. Ogle

K. Ragnars

G.M. Reistad

P. Sangnier

F. Studt

E. Tan

S. Thorhallson

E. Tongiorgi

$\mathrm{K} . \mathrm{B}$. Tonnésson

D.F. Towse

L.B. Werner 


\section{Contents}

Abstract . . . . . . . . . . . . . . . . . . . . . 1

Introduction (J.H. Howard) ..................... 2

Purpose of Report . . . . . . . . . . . . . . . . . . 2

History of Project . . . . . . . . . . . . . . . . . . 2

Importance of Nonelectrical Applications

of Geothermal Resources . . . . . . . . . . . . . . . . . 3

Nonelectrical Geothermal Systems Development . . . . . . . . . . . 5

Finding the Exploitable Resource (E. Barbier and M. Fanel11). . . . . 5

Inventory and Survey of Surface Manifestations . . . . . . . . 6

Hydrogeology . . . . . . . . . . . . . . . . . . . 7

Geochemistry . . . . . . . . . . . . . . . . . 8

Geophysical Methods . . . . . . . . . . . . . . . . . . 9

Exploratory Drilling of Wells . . . . . . . . . . . . . . 13

Cost of Exploration Program . . . . . . . . . . . . . . . 13

Drilling, Extraction and Distribution (G.E. Brandvold

and B.C. Marshall) . . . . . . . . . . . . . . . 14

Drilling ........................ . . . 14

Extraction ........................ 18

Distribution . . . . . . . . . . . . . . . . . . 21

Uses (J.H. Howard) . . . . . . . . . . . . . . . . . . 28

Disposal of Geothermal Fluids (J.F. Kunze) . . . . . . . . . . . 31

Applications . . . . . . . . . . . . . . . . . . 37

Residential and Commercial Applications (G.M. Reistad

and G. Bodvarsson) . . . . . . . . . . . . . . . . 37

Introduction ... . . . . . . . . . . . . . . . . 37

Geothermal Resources for Low-Temperature Utilization . . . . . . 37

Technoeconomics of Geothermal Space Heating . . . . . . . . . . 38

Survey of Existing Systems . . . . . . . . . . . . . . . 43

Future Trends . . . . . . . . . . . . . . . . . . . 58

Agricultural Applications of Geothermal Energy (C.C. Barton) . . . . 58

Introduction . . . . . . . . . . . . . . . . . . 58

Greenhouse Applications of Geothermal Waters . . . . . . . . . 59

Animal Husbandry . . . . . . . . . . . . . . . . . . 64

Aquaculture . . . . . . . . . . . . . . . . . . 64

Summary . . . . . . . . . . . . . . . . . . . . 65 
Industrial Applications of Geothermal Energy (G.M. Relstad) . . . . . . 65

Introduction . . . . . . . . . . . . . . . . . . . 65

Pulp, Paper and Wood Processing . . . . . . . . . . . . . . 66

Diatomaceous-Earth Plant . . . . . . . . . . . . . . . 73

Investigated Potential Uses . . . . . . . . . . . . . . . 76

Economic Considerations (D.F. Towse) . . . . . . . . . . . . . 80

Introduction . . . . . . . . . . . . . . . . . . . 80

Economic Analysis . . . . . . . . . . . . . . . . . . 80

Sources of Cost Estimates . . . . . . . . . . . . . . 80

Initial Capital Costs . . . . . . . . . . . . . . . . 81

Annual costs . . . . . . . . . . . . . . . . . 81

Générálizations . . . . . . . . . ......... 83

Savings ....................... . . 84

Summary . . . . . . . . . . . . . . . . . . . . . 84

Regulatory Considerations (N.B. Crow, J.J. Cohen and K.B. Tonnesson) . . 87

Introduction . . . . . . . . . . . . . . . . . . . 87

Regulatory Philosophy . . . . . . . . . . . . . . . . . 87

Environmental Impacts . . . . . . . . . . . . . . . . 88

Regulatory Practices (U.S.A.) . . . . . . . . . . . . . . 89

Control of Geothermal Drilling and Production Operations . . . . 89

Property Rights . . . . . . . . . . . . . . . . . . . 90

Conflict with Regulation of Other Resources . . . . . . . . . . 94

International Regulatory Practices . . . . . . . . . . . . . . . . . . 94

Introduction . . . . . . . . . . . . . . . . . . . . . 94

Representative Regulatory Practices . . . . . . . . . . . . 94

Problems . . . . . . . . . . . . . . . . . . . 100

Future Needs . . . . . . . . . . . . . . . . . . . . . 102

Problems and Possibilities (J.H. Howard) . . . . . . . . . . . 103

Introduction . . . . . . . . . . . . . . . . . 103

Problems . . . . . . . . . . . . . . . . . 103

Cultural Problems. . . . . . . . . . . . . . . . 103

Economic Problems. . . . . . . . . . . . . . . 103

Technical Problems . . . . . . . . . . . . . . . 104

Institutional/Legal Problems . . . . . . . . . . . . 104

Future Possibilities . . . . . . . . . . . . . . . . . 104

Further Project Phases . . . . . . . . . . . . . . . 105 -iv- 
Acknowledgements . . . . . . . . . . . . . 106

References . . . . . . . . . . . . . . . 107

Appendix A: Minutes of the CCMS Nonelectrical Project Pilot-Study

Meeting, Paris, France, June 25, 1975 . . . . . . . . . . 117

Appendix B: Italian Nonelectrical Uses of Geothermal Resources . . . . 124

Appendix C: Developments in Turkey ............ 134

Appendix D: Developments in New Zealand . . . . . . . . . 137

Appendix E: Developments in the Philippines ........... 141

Appendix F: Agricultural Applications of Geothermal Energy . . . . 144

Appendix G: Index of Contributors to This Report and Other Workers

in the Field of Geothermal Energy . . . . . . . . . . . . . . 157 


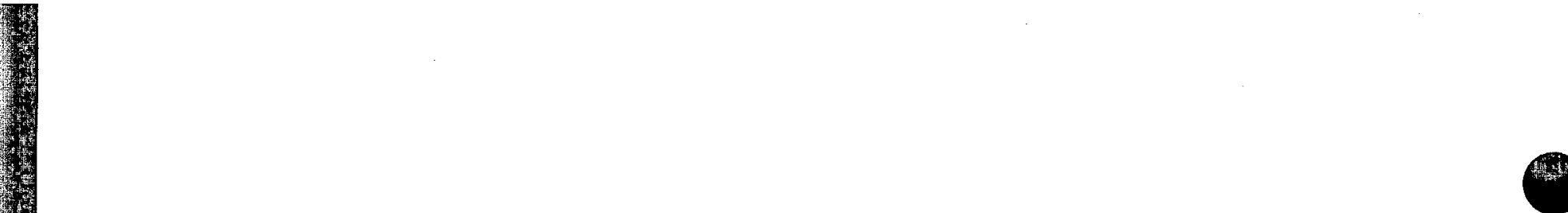

0

-

$$
\text { (1) }
$$
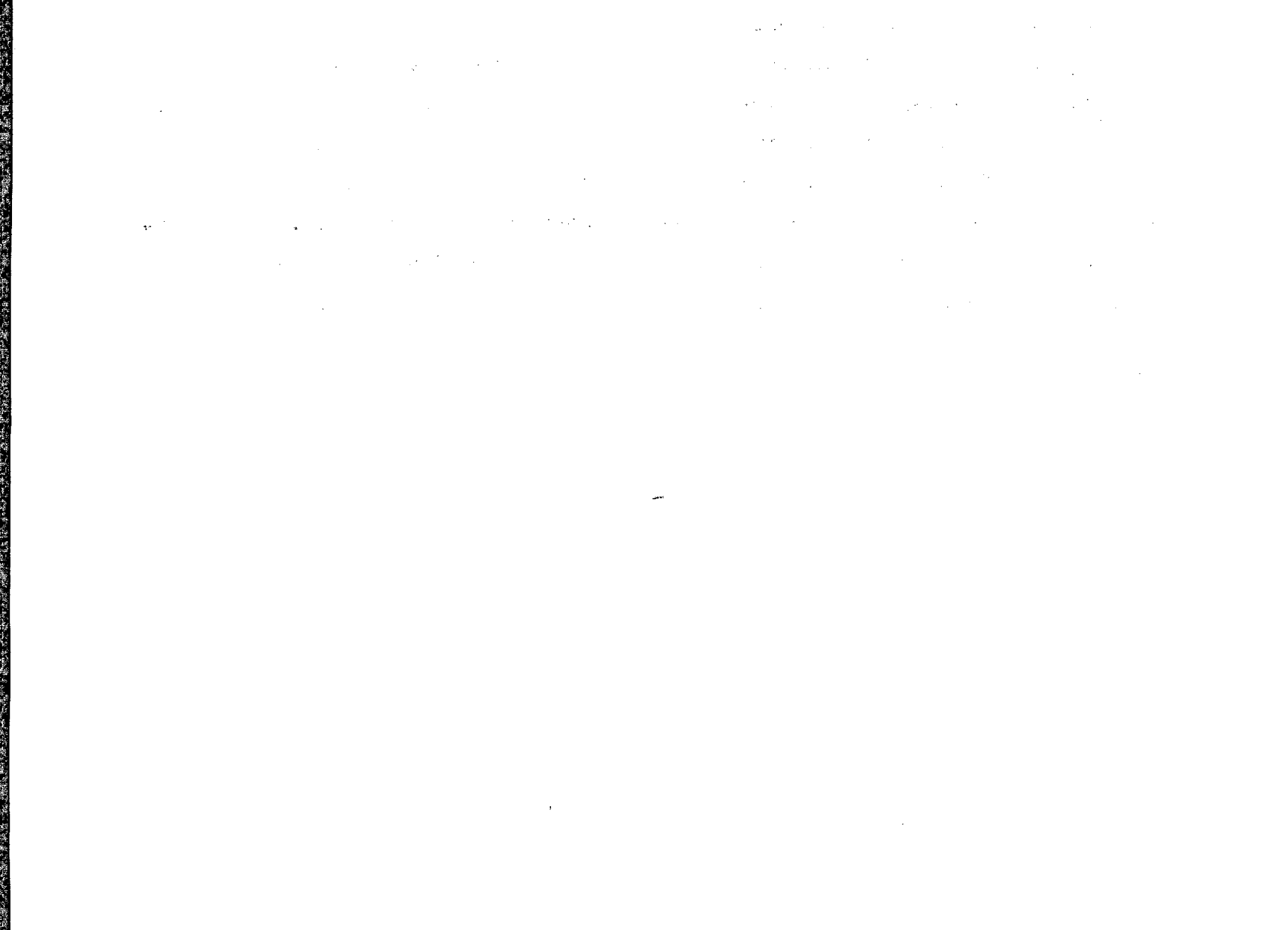

Cr

\section{.}




\title{
PRESENT STATUS AND FUTURE PROSPECTS FOR NONELECTRICAL USES OF GEOTHERMAL ENERGY
}

\author{
Abstract \\ This report, which is part of a \\ study initiated by the NATO Committee \\ on the Challenges of Modern Society \\ (CCMS), describes the current status \\ of nonelectrical uses of geothermal \\ resources. Such resources are defined \\ as geothermal fluids between the \\ temperatures of 50 and $160^{\circ} \mathrm{C}$. \\ Current and potentlal uses of these \\ resources including residential and \\ commercial, agricultural and indus- \\ trial applications are described. \\ Also discussed are exploration and \\ drilling; extraction and distribu- \\ tion; environmental impact; and \\ economic and regulatory problems. \\ Applications in a number of countries \\ are described. Among the report's \\ conclustons are: \\ - Geothermal resources are widely \\ distributed throughout the \\ wor1d. \\ - The extraction of these resources \\ presents no serious technical \\ problems. \\ - A wide variety of economically \\ viable applications for these \\ resources currently exists. \\ - Current nonelectrical applica- \\ $t$ Ions have a favorable economic \\ structure compared with those \\ of other energy sources. \\ - Disposal of spent fluids has a \\ significant ecological impact. \\ Reinjection appears to be the \\ most likely alternative. \\ - The legal and institutional \\ framework surrounding these \\ applications needs both clari- \\ fication and simplification.
}




\section{Introduction}

PURPOSE OF REPORT

This report has four basic purposes. These are:

- To summariźe what has thus far been done in the way of nonelectrical applications of geothermal energy.

In summarizing what has been done, sufficlent Information hàs beèn includéd to give the reader a good insight into the principles of an application. Detailed information, howêver, can be obtained from the réferences cited.

- To act as a source of reference information for those interested in possible development or exploitation of a geothermal resource for nonelectrical purposes.

This includes literature references, reports of current activity and leads such as the names and addresses of Individuals knowledgáble in various aspects of nonelectrical applications.

- To define the problems affecting the nonelectrical applications of geothermal resources.

This includes both technical and nontechnical (e.g., financing) problems. This report includes sections on geothermal systems development and on economics and regulations.

- To determine whether further nonelectrical geothermal development is warranted and, if so, to recommend a course of action.

This discussion evaluates economic, technical and geographic factors affecting continued development.

HISTORY OF PROJECT

In October, 1973 the North Atlantic Treaty Organization (NATO) Committee on the Challenges of Modern Society (CCMS) initiated a study of the nonelectrical uses of geothermal resources. This project; which has become known as the Geothermal Pilot Study, is currently being funded by the U.S. Energy Research and Development Administration (ERDA). Since the pubilication of its original charter, the nations participating in this study have come to include Canada, the Federal Republic of Germany, France, Iceland, Italy, Mexico, New Zealand, the Philippines; Portugal, San Sàlvador, Turkey and the United States. 
In April, 1974 Canadian, West German, French, Italian, Mexican, New Zealand, Turkish, and United States representatives met in New Zealand to discuss the preparation of a report on nonelectrical applications. Subsequent to the New Zealand meeting certain members of the Working Subcommittee toured sites of Italian and French applications and then convened in Iceland to see Icelandic applications. While in Iceland, the group formulated the general outline of the present report.

A draft of the final report was issued in April, 1975, and comments on it were discussed at the time of the Second United Nations Geothermal Symposium in May, 1975. A number of areas of concern were defined at the May meeting, e.g., financing of projects, and these served as the focus of a meeting held in Paris in June. The minutes of the June meeting are included as Appendix $A$ of this report and the essence of that meeting as well as other items bearing on the future of the nonelectrical project are summarized in the last section ("Problems and Possibilities").

The descriptive or current-status phase of the work of the Nonelectrical Uses Subcommittee comes to a close with the issuance of this report. It was agreed at the June meeting that leadership of the subcommittee would be assumed by the Government of France. They will lead the effort as the work changes emphasis from a review of status of existing applications to the possibility of carrying out new, nonelectrical applications.

IMPORTANCE OF NONELECTRICAL APPLICATIONS OF GEOTHERMAL RESOURCES

Note the following points:

- World-wide today, nonelectrical applications of geothermal resources are a significant fraction of electrical applications. Table 1 shows power currently available from geothermally fired electric generating plants. Total power amounts to approximately $1100 \mathrm{MW}$ with an additional $600 \mathrm{NW}$ planned. Tables 4,5 , and 6 show that the power associated with nonelectrical applications amounts to about $5500 \mathrm{NW}$. Note, however, that the comparison is not between like activities. The efficiency of use of geothermal resources for nonelectrical purposes is greater than for electric power production. Assuming, for example, a $10 \%$ conversion efficiency for electric power production and 85\% conversion efficiency for nonelectric applications, the 
Table 1. Current and planned world geothermal power production. (After Barbier; 1975)

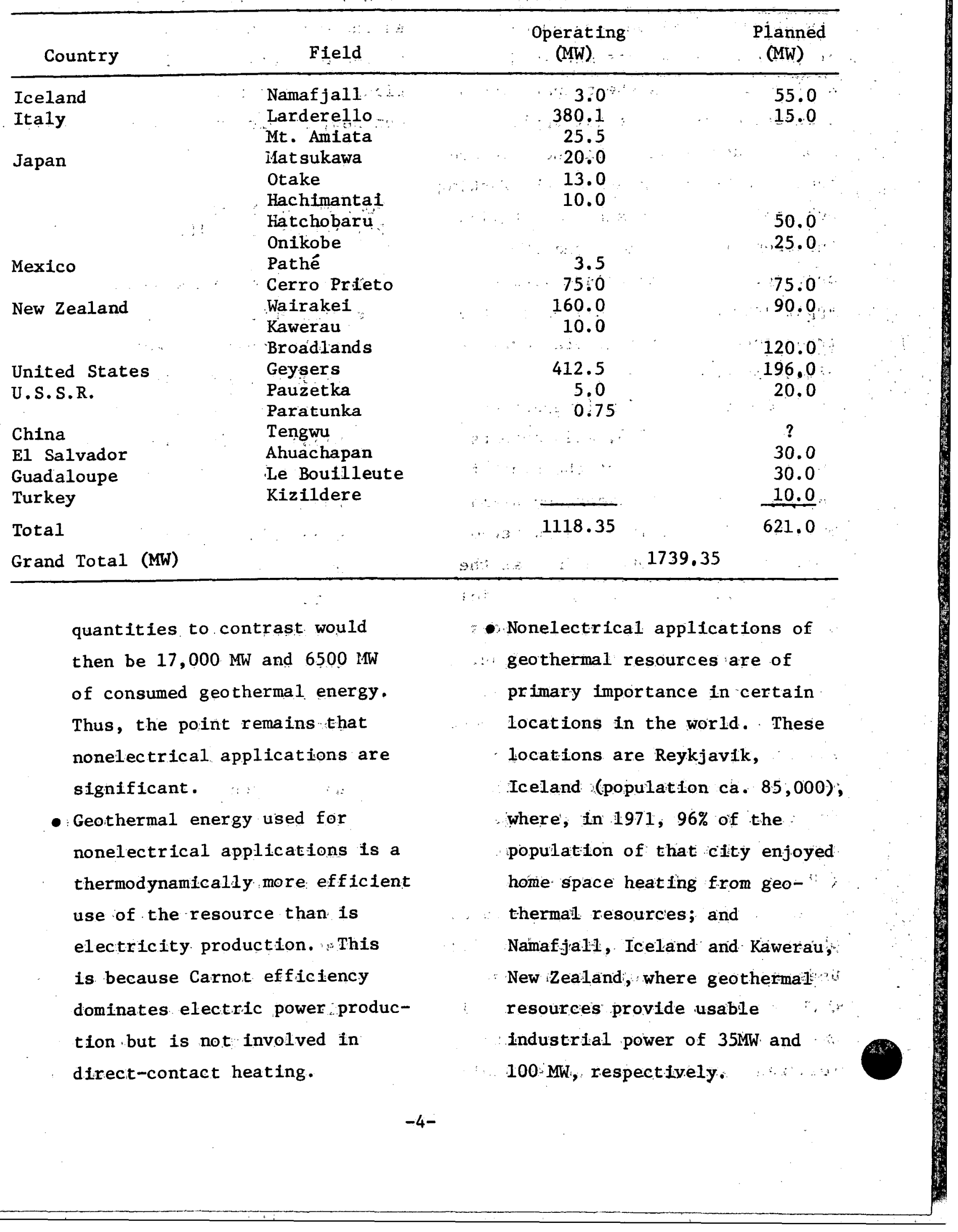


- It appears that the full potential of nonelectrical applications of geothermal resources has not been realized. Many nonelectrical applications have been carried out on a "doit-yourslef" basis. There has been no systematic development and promotion of the technology for such applications in most parts of the world. To date, only Iceland and New Zealand have endeavored to make nonelectrical geothermal applications a principal energy technology.

\section{Nonelectrical Geothermal Systems Development}

FINDING THE EXPLOITABLE RESOURCE

The exploitation of hot waters for nonelectrical uses of fers encouraging prospects for the future In that such use can lead to notable savings of high-quality (and consequently-high cost) energy. In this context "hot" waters means waters, confined or not, with temperatures between $50^{\circ}$ and $160^{\circ} \mathrm{C}$. These temperature limits are not arbitrary but have been determined by the following:

- $50^{\circ} \mathrm{C}$ represent the minimum temperature for greenhouse heating. Utilization of geothermal water with temperatures less than $50^{\circ} \mathrm{C}$ is quite limited and therefore of minor economic value. Such minor, limited uses include mushroom growing, heating of swimming pools, deicing, and fish hatching.
- $160^{\circ} \mathrm{C}$ represent the limit above which it may become more attractive to use the hot water in a binary-cycle system for the generation of electricity, with the heating of intermediate fluids such as isobutane. Power plants of this type have, in fact, an efficiency close to that of plants, already in operation, which use geothermal fluid directly (J.H. Anderson, 1973).

The exploitation of hot waters for nonelectrical uses in the range of temperatures mentioned above has an economic-feasibility 1imit. This limit depends on the depth of the reservoir containing these waters. Faca (1973) fixes this limit at 2000 m. Below $2000 \mathrm{~m}$, drilling costs rise exponentially (cf. Anderson, 1973, p. 164, Fig. 1) and become 
excessive when compared to the value

of the extractable energy.

Hot waters occur widely over all continents. For instance, Waring (1965) lists 1185 areas of hot springs in the United States. In Europe, the Paris and Hungarian basins are we11-known. Russian experts indicate that at least $50 \%$ of the Soviet underground contains fluids between 50 and $130^{\circ} \mathrm{C}$ which are industrially utilizable (Tikhonov and Dvorov, 1970).

Exploration for hot waters makes use of exploration techniques usually applied to the search for cold waters, as well as some of those used in locating steam fields. Techniques for finding hot waters can be 1isted under the following categories:

1. Inventory and survey of the surface manifestations

2. Hydrogeology

3. Geochemistry

4. Geophysical methods

5. Exploratory wells

Inventory and Survey of Surface Manifestations

A knowledge of the surface-heat manifestations and their physical and chemical characteristics is of fundamental importance. This information, which can usually be obtained simply and at a relatively low cost, is extremely useful for subsequent planning of exploration.
The surface-heat survey has two consecutive phases:

1. The collection; processing, and standardization of published and recorded data relative to: (a) the locales of existing hot springs and of fossil hot springs (e.g., travertine deposits);. (b) chemical analyses of water, and gas and/or hydrothermal alterations associated with these locations; and (c) temperatures, flow-rates, and their variations with time.

2. The gathering of new data, especially about heat manifestations for which no specific data exist in the literature, checking of existing data, and additional samp1ing.

The collecting of water samples to determine their major chemical components is not a complicated procedure and does not require highly specialized personnel, but must be carried out following directions of the laboratory. which will subsequently make the analyses. The cost of this operation lies mainly in the sample analysis. Experience has shown that spectal care, however, must be taken if sampling is directed towards research on the minor chemical. 
components as well as the trace elements.

Collecting gas samples from springs or fumaroles presents some difficulty. Although it is easy to make mistakes in sampling, especially through contamination of the sample with the air (shown by the presence of $\mathrm{O}_{2}$ in the sample), these can be avoided by careful field procedures. Speclal devices (e.g., the Dräger tube system) permit immediate and rapid field analysis of gas samples.

Temperature measurements of springs and fumaroles can be carried out with ordinary mercury thermometers or, with a greater accuracy and convenience, with electrical thermometers (using thermocouples, thermistors, and thermoresistances) (World lfeteorological Organization, 1965). In outof-the-way or inaccessible areas, the localization and evaluation of temperature can be achieved by using airborne infrared sensors.

\section{Hydrogeology}

This technique includes not only studies of ground water but also the strictly geological studies that lead to the stratigraphic and structural framework for so-called hydrogeological surveys. The latter permit the correlation of hydrothermal manifestations with faults, fractures and other tectonic features. The possi- bilities offered by photogeological techniques are also of interest. These are, in particular, able to provide rapidly and at a very low cost, valuable information on the surface geology, geomorphology and, by statistical analyses of fractures and lineations, a useful contribution to geophysics in locating buried structures that may be hot water reservoirs.

The study techniques applied in thermal hydrogeology are not appreciably different from those generally used in cold-water research. These techniques are aimed at revealing the primary elements of an aquifer so as to reconstruct the underground pattern by compiling maps of the piezometric levels.

These elements of an aquifer are:

- Recharge and outflow areas

- Hydraulic gradients

- Aquifer pressures and probable direction and velocities of water movement through the area

- Depth to water table and form of surface of water table from wells through the catchment area

- Presence of artesian aquifers For thermal aquifers, the element of temperature must also be included.

Temperature plays a very important role. Besides determining the economic value of the resource, it affects the 
existence of convective movements and their pattern. Information on temperatures is obtained in various ways; for instance, by measurements of surface thermal manifestations, by measurements in wells, and by geotherma1 prospecting. Such information permits the reconstruction of deep hydrothermal systems and hence the location of their hottest parts. The use of mathematical models, which have so far proved to be of great help in hydrogeological studies in general, is now also being attempted in hydrothermal systems; although, in this case, some difficulties arise from having to take the temperature parameter into consideration (Donaldson, 1970; Mercer and Pinder, 1973).

\section{Geochemistry}

Geochemical techniques are widely used as prospecting methods in the search for geothermal fluids. The chemical characteristics of hot springs represent an important guide in programing the later phases of exploration. Knowledge of the chemical content of the water permits deductions about the nature of the rocks forming the reservoir and about the flow pattern of the water. Geochemical methods are particularly important and useful in geothermal exploration because of their relatively low cost compared to the various geophysical methods.

As regards exploration some geochemical methods offer the interesting possibility of revealing the temperature of deep reservoirs from a study. of the surface manifestations and thus of evaluating the economic feasibility of continuing research. In order to make these evaluations, analysis is made of those chemical components in the heated water which are governed by temperature-dependent solution equilibria. These components or factors are as follows:

- Silica, whose content in a hot spring increases with a rise in temperature. Therefore, by comparing the silica content of the thermal water and the quartz solubility curve vs temperature we can deduce the reservoir temperature, if we assume that the silica remains in metastable equilibrium in solution through the temperature variations occurring between the reservoir and the surface (White, 1970).

- The $\mathrm{Na} / \mathrm{K}$ ratio, which decreases with an increase in temperature (White, 1970; Fournier and Truesde11, 1973).

- Other ratios such as the $\mathrm{Mg} / \mathrm{Ca}$; $\mathrm{Na} / \mathrm{Ca}, \mathrm{Cl} /\left(\mathrm{HCO}_{3}+\mathrm{CO}_{3}\right)$ and C1/F (White, 1970; Fournier and Truesde11, 1973). 
A further application of geochemistry is the use of hydrogen and oxygen isotopes for identifying recharge areas of the geothermal reservoirs (Craig, 1973). In fact, the $\mathrm{D} / \mathrm{H}$ and $0^{18} / 0^{16}$ ratios are affected by topographical altitude of condensation of meteoric waters which feed the thermal aquifers. Waters are poorer in heavy isotopes with an Increase in altitude (Craig, 1973). Also, tritium and $\mathrm{C}^{14}$ radioisotopes permit an evaluation of the age of the geothermal fluids, that is, the time taken from their absorption. Tritium and $\mathrm{C}^{14}$ analysis also leads to understanding of the eventual mixing phenomena between deep and surface waters (Craig, 1973; Begemann, 1963; White, 1970).

\section{Geophysical Methods}

The majority of classical geophysical techniques, namely, seismic, gravity and magnetic surveys as applied to geothermal research, can be defined as indirect methods. These methods are not directly associated with the properties of the hot fluids which are being sought. Rather, they yield information about the attitude and nature of the host rocks. Therefore, no particular information will be given on the application of these techniques, which, in exploration for hot waters, are only a support to geology.

In the search for hot waters, certain methods are considered to directly reveal variations in the physical properties of rocks due to the presence of thermal fluids. These include electrical-resistivity, electromagnetic and thermalmeasurement methods.

\section{Electrical-Resistivity Methods}

Electrical-resistivity methods of prospecting have been most widely used so far. Wide experience with the so-called DC-resistivity methods has shown that they effectively localize potentially productive horizons. Temperature, porosity and salinity of interstitial fluids and the clay content tend to be higher in geothermal reservoirs than in the surrounding rocks. Consequently, the resistivity of the geothermal reservoirs is relatively low. The contrast in resistivity between the hot-water-saturated rocks and the surrounding colder rocks can reach the ratio of $1: 100$, although it is usually on the order of 1:5 (Meidav, 1974).

There are several resistivity measurement techniques and each could be applied in successive exploration phases. These techniques are based on injection of current into the 
ground and measurement of voltage differences produced as a consequence over the surface of the ground. For reconnaissance surveys, the roving dipole technique is particularly useful, especially if applied over wide areas. (For details of this method, see Meidav, 1974.) . This method has the advantage of costing little per unit area, of being faster than the other methods and not requiring straight survey lines. It is therefore particularly suitable over rugged ground. Its disadvantage is that it provides only a general eyaluation of the area under exploration.

For semi-detailed surveys, the dipole-dipole technique may be used. The dipole-dipole technique gives a resistivity cross-section on the line of the dipole-dipole profile (Keller, 1966). It is a slower method than the roving dipole method. Although straight lines must be run, the method is nevertheless logistically simple. It is used advantageously to improve the details given by the roving dipole method. Depth measurements made by the dipole-dipole method require a complicated data analysis and great care in its interpretation.

For detailed surveys, the Wenner* or Schlumberger electrode arrangements are commonly used. They differ only in the spacing of the current and the voltage electrodes on a single line (Keller and Frischknecht, 1966). Electrode arrangements of this type are used to resolve some of the finer. details of a geological structure of an area. These methods have been used for some time now in every kind of mining research and an extensive documentation is therefore available (Ireidav and Furgurson, 1972).

Electric methods may not be the most suitable for measuring the low resistivities of the geothermal areas because of the very low level of the electric signal received by the instruments. Where this is the case, preference may be given to induction methods (electromagnetic) in which the signal increases as ground resistivity decreases, thus giving better results in the areas of greater interest. Furthermore, in geothermal areas, the surface resistivity is sometimes so high as to prevent current from entering into the ground, and thus to limit the efficacy of DC methods. The induction methods help eliminate the screen effect of very resistive surface rocks.

\footnotetext{
* Reference to a company or product name does not imply approval or recommendation of the product by the University of California or the U.S. Energy Research \& Development Administration to the exclusion of others that may be suitable.
} 


\section{Electromagnetic Methods}

Induction or electromagnetic methods are a means of determining the electrical resistivity distribution in the earth by means of surface measurements of transient electric and magnetic fields. These fields can be naturally or artificially generated. Among the methods used, the best results for thermal areas have come from the so-called two-loop method and from the magnetotelluric method (Keller, 1970). The two-1oop method is suitable up to depths of some tens of metres. The magnetotelluric method makes use of natural "noise" in the frequency range of about $8 \mathrm{~Hz}$ to as high as $20 \mathrm{kHz}$. A variation of the magnetotelluric method, is now being developed and shows very promising results so far. It is the so-called five-component magnetotelluric method (Musé, 1973). Three components of the magnetic field and two components of the electric field are measured. It renders possible prospecting based on a very close network of recording stations. Thus, it can reveal contrasts in resistivities regardless of depth. It facilitates the detection and interpretation of areas within a field that have different significance from a geothermal point of view. The disadvantage of induction methods for prospecting lies mostly in the greater complexity involved in determining the ground resistivity compared to the DC methods.

In addition to the geophysical methods that have already been mentioned and that are, moreover, in general use in mining research, there are techniques that are peculiar to geothermal research.

\section{Thermal-Measurement Methods}

Geotherma1-prospecting methods that measure the underground thermal conditions are very widely used. Through measurement of the temperature in the ground or a determination of geothermal gradients or heat flow, they reveal the location and intensity of thermal anomalies. Geothermal prospecting, therefore, can give:

1. Proof of the existence of hot fluids in areas without surface manifestations, but with geostructural and geohydrological characteristics that favor the occurrence of hydrothermal circuits.

2. Greater accuracy in siting exploratory drilling in areas that have already been recognized as being potentially productive.

3. A more precise delineation of previously localized thermal areas with subsequent saving in proposed exploitation wells 
in nonproductive, boundary areas.

Heat flow measurements for georthermal prospecting are carried out by drilling shallow wells. The :. density of drilling depends on local. conditions and the results required; but there is generally one hole for. every 5-25 $\mathrm{km}^{2}$ (Banwe11, 1970). They are usually a few inches in diameter. Their depth must be such as to avoid both the effects of annual surface thermal oscillation in the ground (negligible, below 20-25 m) and of thermal disturbances due to circulation of superficial ground waters.

The geothermal gradient is obtained from temperatures measured at various depths in the bottom part of the well by means of electric thermometers that give accuracies of the order of a hundredth of a degree centigrade. Heat conductivity of the rocks in the area of the well where the gradient was measured can be determined in the well itself by inserting a special probe or, more easily, in the case of most types of rock, by performing these tests on cores in the laboratory. The product of these two values, the gradient and conductivity, gives the heat flow.

Prospecting that involves drilling operations and core extraction is obviousily expensive. It is therefore preferably restricted to aquifers that are extensive and very hot and that, therefore, may repay the costs for this kind of program.

Sometimes gradient measurements alone are enough to provide the information required in geothermal prospecting. However, such an opportunity occurs only in areas that are lithologically homogeneous and where thermal conductivity can be regarded as constant. The same observations regarding cost of survey that were made for heat flow are valid in this case also.

Geothermal prospecting techniques that measure temperatures at depths of 1-2 metres have been tried (Dedkova, et al., 1970). These methods are affected considerably by the many sources of thermal disturbances (flow of superficial ground waters, vegetation effects, daily and seasonal thermal variations, topographical conditions, etc.) and require a long, complicated and sometimes uncertain job of correcting the measured data. Nevertheless, this type of prospecting (i.e., without drilling) represents a notable economic advantage compared to those described previously. The method has been experimented with and has been used with good results mainly in the eastern European countries for localizing hot waters at shallow. depths (a few hundreds of metres). 
Among the geothermal-prospecting techniques acquired most recently is that of the ground infrared radiation survey using a special receiving and recording device which can operate either directly on the ground or from an aircraft (Hodder, 1970; Hochstein and Dickinson, 1970). The spectral bands most commonly used are the

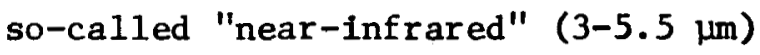
and "far-infrared" $(8-14 \mu \mathrm{m})$. . These are therefore well beyond the limit of visible radiation (which lies around $0.75 \mu \mathrm{m}$ ). The signals recorded and suitably processed are used for compiling thermal maps of the ground. The application of this method to geothermal research is, however, complicated by the fact that the ground surface temperatures, although recorded with sufficient accuracy, depend only in part on the deep thermal conditions, while they are affected by various surface conditions (vegetation, ground humidity, solar radiation, etc.). These techniques can nevertheless be helpful in the preliminary phase of exploration and, above all, in out-of-theway or inaccessible areas. They have been applied recently by the United Nations in Ethiopia and Kenya from a flying altitude of 900 metres. They easily revealed geothermal features of 4 square metres and with temperature differences of $10^{\circ} \mathrm{C}$ or even less compared to the surrounding environment (De Donato, 1974).

\section{Exploratory Drilling of Wells}

The final stage of an exploration survey, that is exploratory well drilling, presents no special features. Usually, the final diameters of such bores are on the order of 4 in., so as to carry out production tests. A pump may be inserted in the case of a shallow well of some hundreds of metres, and compressed air (gas lift) may be injected in deeper wells.

\section{Cost of Exploration Program}

The cost of an exploration program depends on:

- Local socio-geographical conditions. These weigh heavily on the budget of an exploration survey in the form of labor costs (whether or not it is specialized); transport costs in relation to site accessibility and the existing communication network; and the availability of service companies in the area.

- Existing knowledge of the local hydrological situation. The quantity and type of data available must be determined and that which is unavailable but necessary must be provided. 
- The objectives that define the total area of the zones to be explored.

These three different elements, which determine the cost of an exploration program, vary greatly from one country to another and even from place to place within a given country. Therefore, it is possible to express costs only in general terms.

To give some idea of these costs, the cost of prospecting in Europe using resistivity measurements (which are those most commoniy used in hotwater research among all the geophysical techniques) is as follows:

- One team of technicians; provided with instruments and equipment, costs between $\$ 350-$ $450 /$ day and can, on average, carry out three electric soundings with the distance between current electrodes $(A B)=1000 / 1500$ metres.

For longer $\mathrm{AB}$ and therefore for surveys at greater depths, efficiency obviously decreases as far as one electric sounding per day with $A B$ at 6000 metres: The cost of $4-$ inch exploŕtory wells fluctuates bétween \$200-250/meter for depths of not more than 500 metres, and reaches $\$ 400 /$ meter at depths of 2000 métres. These costs include completion of the we11.
DRILLING, EXTRACTION

AND DISTRIBUTION

\section{Drilling}

Vast quantities of low temperature geotherma 1 energy $\left(\mathrm{T}^{\prime} \leq 100^{\circ} \mathrm{C}\right)$ are avaliable at relátively shallow depths in the earth's crust. Although the average thermal gradient is $30^{\circ} \mathrm{C}$ per kilometer, gradients of 150 to $180^{\circ} \mathrm{C}$ per kilometer have been observed in geothermal areas. SuItable temperatures are found in sedimentary; igneous, and metamorphic terrain. Current drilling technology is cäpable of drilling into lowtemperature geothermal reservoirs with only minor problems. Presentday standard pêtroleum drilling tecthology can drill to $10 \mathrm{~km}$ and $250^{\circ} \mathrm{C}$. Drilling and completion of wells at temperatures no greater than $100^{\circ} \mathrm{C}$ is accomplished routinely.

The major difference between drilling for low temperature geothermal resources and drilling for hydrocarbons results when the geothermal resource is imbedded in non-porous, crystalline rock. The tat" drilling of crystalline rock is much more difficult than drilling sedimentary formations (Gätlin, 1960). The vibration and abrasive nature of the rocks cause extreme wear on both bits and drill pipe. In fact, in 
geothermal drilling in the Geysers area of California, drill strings are considered expendable (Cromling, 1973). Air drilling is often used to drill into the producing formation to avoid damage to the producing formation. Drilling in the crystalline rock closely resembles mineralexploration drilling in the western United States.

When the geothermal fluid lies in a sedimentary bed, drilling proceeds as in standard hydrocarbon drilling. In fact, zones of geothermal potential lie in regions of hydrocarbon accumulation. Large zones of hot mineralized water which are thought to contain large quantities of methane gas in solution occur, :for instance, in the Gulf Coast région of the United States (Whiting, 1974).

The technology required for drilling into low-temperature geothermal reservoirs is similar to that used in mineral and hydrocarbon exploration (Matsuo, 1973). The primary aspect of consideration in drilling into these reservoirs is economic. Present drilling technology is expensive, and the costs are rising rapidly. Drilling costs versus depth for ofl and gas wells are shown in Fig. 1. Costs increase exponentially with depth. Completion costs are given as the difference between a production well and a dry hole. Completion costs for low temperature geothermal fluids may vary somewhat from oil or gas wells but the main portion of costs is in drilling.

For the harder crystalline rocks the drilling costs increase dramatically. Fig. 2 gives the drilling rate versus bit loading for various rock types (Gatlin, 1960). Not only does the increased drilling time required for crystalline rock raise costs; but, as indicated before, expendable equipment costs increase significantly. "The cost estimates for various-depth wells of crystalline rock are given in Table 2. These costs are as much as 100 per cent higher than comparable-depth sedimentary wells.

The costs of drilling into most low-temperature geothermal fluids w111 mäke many reservoirs uneconomical for production. Also, added to the actual cost of drilling are the costs for land acquisition and geological survey. The costs of each phase; 1.e., acquisition, survey, and driliing are on the same order (Altseimer, 1974). The exact percentage of the total cost for each phase depends upon the particular project.

The primary problem of drilling and completing low-temperature geothermal wells is the fact that almost all the readily available techniques and equipment are designed specifically 


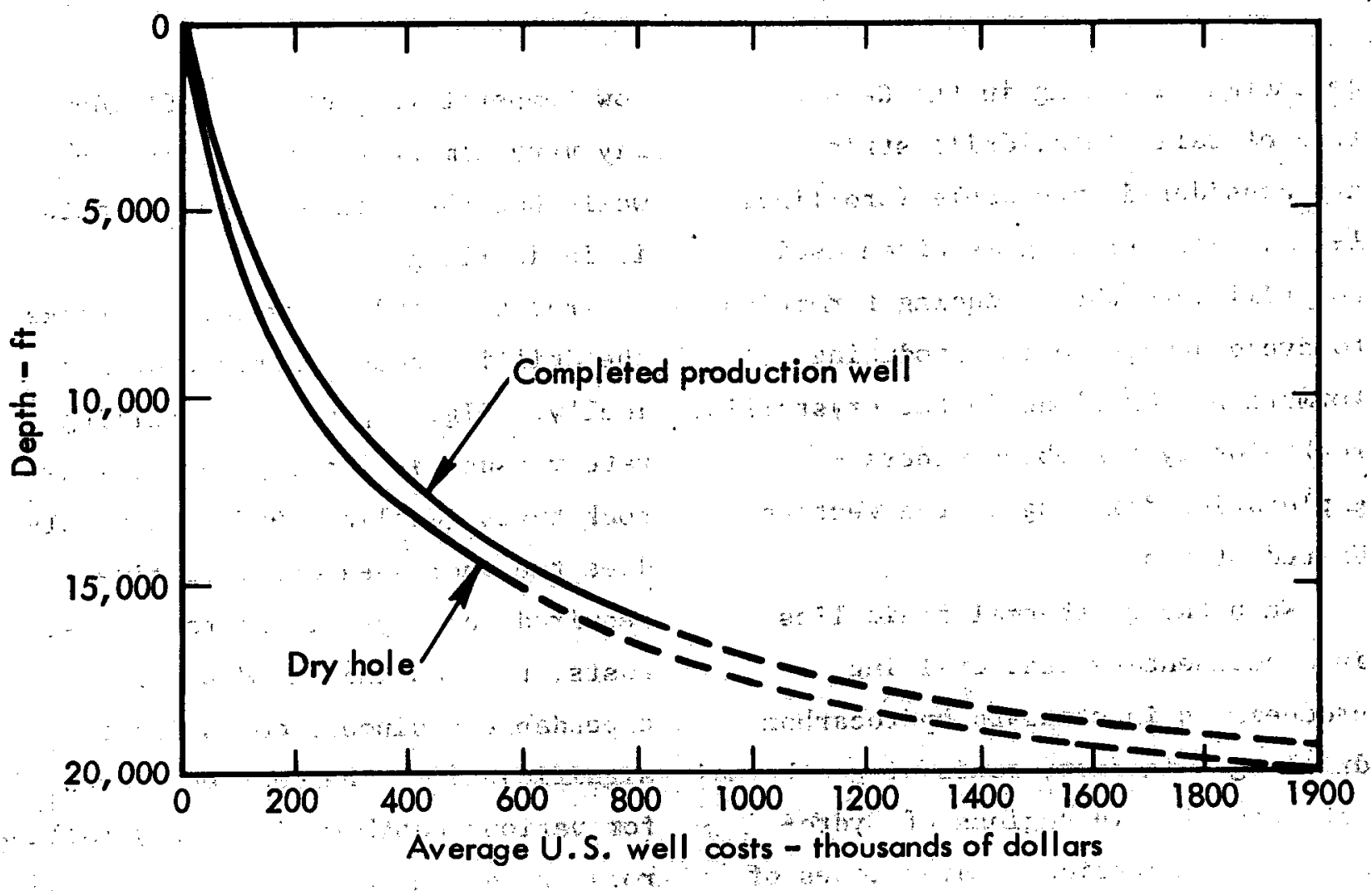

Fig. 1. Ayerage drilling costs for dry holes and for completed oil wells, as a function of depth. Difference between the two curves represents completion costs. These costs may be thought of as a guide to minimum costs of geothermal wells (Source: World Oil, Feb. . 197.4).

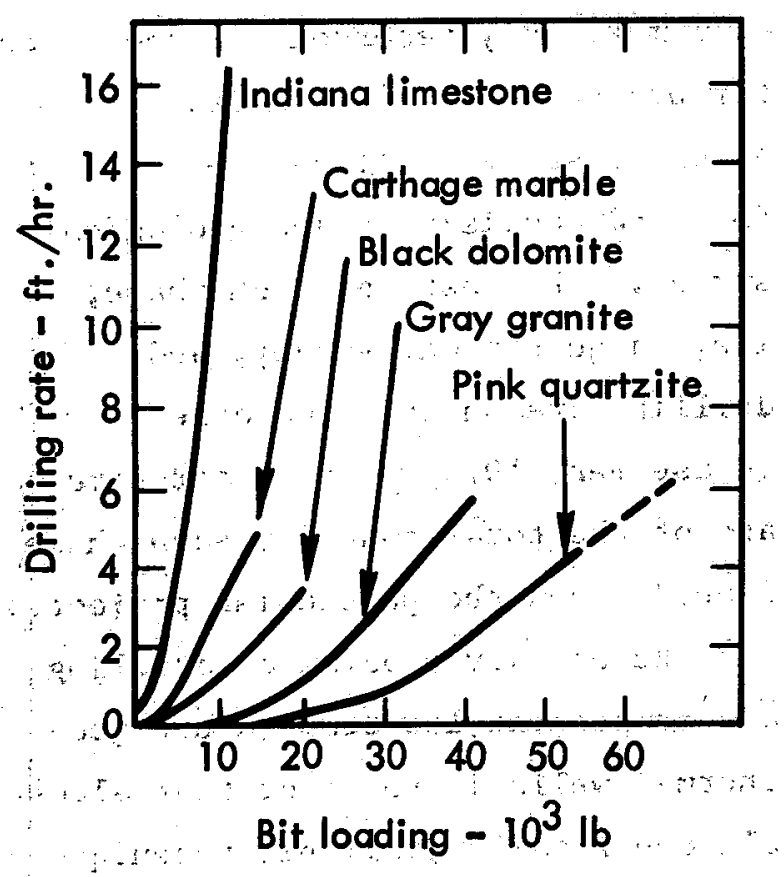

Fig. 2. Drilling rates as a function. of bit loading for various rock types, under atmospheric pressure confining conditions. The drilling rate for some rock types likely to be encountered in drilling of geothermal resources (e.g., Gray granite) is much lower than that for rocks representative of ordinary oil field conditions (e.g., Ind iana limestone). Consequently; costs of geothermal wells is expected to be greater (Gatlin, 1960). 
Table 2. Drilling costs and drilling time for various depths of drilling in crystalline rock.

\begin{tabular}{|c|c|c|}
\hline $\begin{array}{l}\text { Depth } \\
(\mathrm{ft})\end{array}$ & $\begin{array}{c}\text { Costs } \\
\text { Thousands of } \\
\text { (1973 Dollars) }\end{array}$ & $\begin{array}{l}\text { Drilling Time } \\
1973 \text { (Days) }\end{array}$ \\
\hline $\begin{array}{r}5,000 \\
10,000 \\
15,000 \\
20,000 \\
25,000 \\
30,000\end{array}$ & $\begin{array}{c}250-350 \\
475-750 \\
600-900 \\
900-2,000 \\
3,000-4,500 \\
4,000-10,000\end{array}$ & $\begin{array}{l}25-50 \\
75-150 \\
250-350 \\
200-350 \\
450-750 \\
750-1100\end{array}$ \\
\hline $\begin{array}{l}---\cdots \\
40,000 \\
50,000\end{array}$ & $\begin{array}{l}-\ldots-\text { PROJECTE } \\
15,000-20,000 \\
25,000-40,000\end{array}$ & $\begin{array}{r}-\ldots-\ldots-\ldots \\
1400 \text { (approximate) } \\
2500 \text { (approximate) }\end{array}$ \\
\hline
\end{tabular}

NOTE: The casing cost for petroleum wells can exceed $50 \%$ of the total cost. A probe hole in crystalline rock is expected to require much less casing.

arilling costs and times do not include coring and data measuring interruptions. This may add $20 \%-100 \%$ to costs.

for oll and gas production. While most such techniques and equipment may be adequate, modifications may be desired for drilling low temperature geothermal reservoirs. The cost of these modifications may be prohibitive unless sufficient quantities are consumed to allow mass production of the items. Certainly, completion techniques for these wells will require the greatest variation from practices of the oll and gas industry. Corrosion and scaling may create problems requiring special steels and descaling techniques. Conventional drilling mud should be adequate for this type drilling.
Cements available for petroleum app1ications will perform acceptably in most cases since the pressures and temperatures are in the range encountered in 011 and gas drilling. Chemical problems, especially with hydrogen sulfide gas, are encountered in the petroleum industry. Suitable techniques for enlarging slim exploratory holes for production need to be available for this application because the hole size in production will normally be larger than that required for the initial exploration. Although present-day drilling technology is capable of drilling into low-temperature geothermal 
reservoirs, significant reductions: in drilling costs must be made in order to make more sources economically feasible. With the high state of development of rotary drilling technology, 1t seems unlikely that major cost cutting improvements will be forthcoming in this area. Rather, new techniques must be devised and developed. At the present time, for instance, very little research into improved drilling techniques is being conducted in the United States. This situation must be changed if the required techniques are to be developed:

\section{Extraction}

The flow rate from and performance of a geothermal reservoir are functions of many parameters. Among, these are the volume of fluid in the aquifer, the permeability of the formation, the physical restrictions of the drilled well and piping, and the type of completion equipment utilized (e.g., pump). Further, depending on the characteristics of the particular reservoir, the fluid may exist at the surface as a liquid, a vapor, or a mixture of the two and may also include solid foreign material and various dissolved gases. Thus, the type of equipment necessary to extract the fluid from the reservoir will depend on the enthalpypressure characteristics of the fluid, its chemistry; and the entrained solids. For low-enthalpy fluids of interest in nonelectrical applications, it is expected that the fluid will generally be desired in the liquid phàse: Thưs, for fluid temperatures above $100^{\circ} \mathrm{C}$, specificpressure and therefore pump requirements are placed on the system to maintain the fluid in its liquid phase or a portion of the fluid enthalpy is dissipated by 'flashing'. If the aquifer is artesian and the fluid temperature is below $100^{\circ} \mathrm{C}$, pumping is not required if the artesian flow rate is sufficient. The permeability of the fluid-bearing formation and restrictions in the wellhead piping control the flow rate. If the flow rate without pump is insufficient for the intended use, pumps can be added to fincrease the flow rate, but the reservolr drawdown and anticipated lifetime may be äfected. In this case, pumps are necessary only to increase the flow rate and are not required to maintain the fluid in a liquid phase since its temperature is below boiling at atmospheric pressure. If the aquifer is not artesian, a pump is required to produce flow and the resulting flow rate is then a function of (1) the installed pump power, (2) the formation permeability, and (3) the weil-casing and plping-pressure losses. 
When the temperature exceeds $100^{\circ} \mathrm{C}$, the fluid can exist at the surface as a 1iquid, a mixture of vapor and liquid, or as a superheated vapor depending on the fluid pressure and temperature. As stated previously, the liquid phase is usually required for low enthalpy nonelectric uses and therefore a pressure above the saturation pressure corresponding to the fluid temperature must be maintained. It is possible that mixtures of vapor and liquid can be utilized directly in some cases, but in general the pressure must be elevated by pumps to maintain single-phase flow. If this is not practical, the two-phase flow can be directed through a separator from which water and steam are extracted separately and each phase may then be used for different applications.

In most geothermal sources the fluid contains dissolved gases such as nitrogen, hydrogen sulfide, and carbon dioxide, and in many instances these gases must be separated and removed. This can be accomplished by piping the fluid into a deaerator in which the fluld is allowed to boil slightly by a reduction in the pressure and the dissolved gases are thus removed. This procedure is also used to adjust the acidity of the water to minimize subsequent corrosion problems (Zoega and Kristinsson, 1970).
The most common type of pump used for completing geothermal wells is a shaft driven, deep-well pump. Many examples of the successful operation of these pumps can be found. Perhaps the most extensive low-temperature geothermal system is the Reykjavik District Heating System in Iceland (Zoega and Kristinsson, 1970). Numerous wells have been developed since 1928 and both artesian and pumped wells are in production. Conventional shaft-driven impellers are mounted from 110 to 120 meters down the drilled borehole and these impellers are connected by drive shafts to electric motors mounted on the surface.

Factors to be considered in the design and selection of a deep-well pump include the pressure drop in the formation and the well casing as well as the pump suction. In addition, sufficient static head to prevent cavitation is necessary. A study of deep-well pumps has suggested that suitable shaft-driven pumps can be designed to operate at depths as great as 335 meters (Holt, et al., 1973). A concept which would permit deeper pump operation has been suggested by Ben Holt Company, an engineering firm in the United States (Holt, et al., 1973). They propose a submersible, down-hole pump in which a high speed centrifugal pump 
is driven by a hydraulic turbine.

The turbine would be powered by high pressure brine pumped down the casing and the pump could, in theory, operate at any depth. However, general. knowledge of the operation of this type of pump is not as well developed as that for shaft-driven pumps and research is continuing on this technique.

For low-energy geothermal wells, a comparison of interest involves the energy required to pump the fluid to. the surface vs the energy available in the fluid as a function of depth. The power necessary to raise the fiuid to the surface is:

$$
E_{p}=\dot{w}\left\{h+h_{p}-h_{s}\right\} 9.804
$$

where

$$
\begin{aligned}
& \mathrm{E}_{\mathrm{P}}=\text { the pump power required }(\mathrm{J} / \mathrm{sec}) \\
& \dot{\mathrm{w}}=\text { mass flow rate }(\mathrm{kg} / \mathrm{sec}) \\
& \mathrm{h}=\text { depth to source (meters) } \\
& h_{p}=\text { pressure loss in well pipe }= \\
& \text { fhu }{ }^{2} / 2 D g \text { (meters) where } \\
& f \text { is pipe-friction factor; } D \text {; } \\
& \text { pipe diameter; h, pipe length; } \\
& \text { g, gravitational constant; and } \\
& u \text {, velocity } \\
& \mathbf{h}_{\mathbf{s}}=\text { static pressure in source } \\
& { }_{\mathrm{P}_{s}} / \rho \text { in meters, where } \rho \text { is } \\
& \text { density of the fluid. }
\end{aligned}
$$

As a conservative estimate, assume $h_{s}=0,1, e,$, standard atmospheric pressure in the source. Further, if we assume that $\mathrm{f}=0.02$, the diameter is 0.1524 meters, and the velocity in the well pipe is 1.8 meters per second, the pump. power becomes

$$
\begin{aligned}
E_{p}=\dot{w}\left\{h+0.02 \frac{h}{0.1524}\left(\frac{1.8^{2}}{19.6}\right)\right\} & \\
& =\dot{w h}\{1+0.0224\} 9.804
\end{aligned}
$$

The question becomes, what increase in fluid temperature as a function of depth is required to justify the addition of pump energy to flow the well. The useful energy in the fluid is

$$
E_{u}=\operatorname{wc} \Delta T
$$

where

$$
\begin{aligned}
\mathrm{E}_{\mathrm{u}}= & \text { useful energy }(\mathrm{J} / \mathrm{sec}) \\
\mathrm{C}= & \text { fluid specific heat }(\mathrm{J} / \mathrm{kg} \cdot \mathrm{K}) \\
\Delta \mathrm{T}= & \text { useful temperature drop }(\mathrm{K}) \text { In } \\
& \text { the fluid } \mathrm{i.e.} \text {, the difference } \\
& \text { in temperature of the fluid } \\
& \text { before and after its use. }
\end{aligned}
$$

If one assumes that fluid available at the surface must contain some 
minimum desired useful energy to justify its use based on the pumping, piping, and transmission costs on the surface, then for increasing depth the fluid temperature must increase at least an amount equivalent to the pump energy required. Thus the available energy must be, as a minimum,

$$
E_{a}=E_{u}+E_{p}
$$

Replacing the available energy $\left(E_{a}\right)$ by

$$
E_{a}=\dot{\dot{w}} C\left(T_{f}-T_{0}\right)
$$

where $T_{f}$ is the fluid temperature, and $T_{0}$ is the lowest temperature at which the fluid might concelvably be discharged, this expression becomes

$$
T_{f}-T_{o}=\Delta T+\frac{10.024 h}{C} .
$$

For $\mathrm{C}=4180 \mathrm{~J} / \mathrm{kg} \cdot \mathrm{K}$ and $\mathrm{T}_{\mathrm{o}}=28^{\circ} \mathrm{C}$,

$$
T_{f}-\Delta T=0.0024 h+28 .
$$

Therefore, neglecting the energy: (and cost) required to drill a well, the fluid temperature must increase Iinearly with depth in order to justify the pumping energy. However, the increase is a very nominal $2.4^{\circ} \mathrm{C}$ per kilometer and the normal thermal gradient more than meets this requirement. An additional factor which cannot be readily included in a quantitative manner in this comparison is the difference between the value of pump energy and of low grade thermal energy. Because of its higher potential, energy utilized to operate pumps has a greater value. Because of associated efficiencies, one could assume that up to ten times as much energy is consumed to produce the pump energy as is actually delivered to the fluid. In that case, the required increase with depth would be $24^{\circ} \mathrm{C}$ per kilometer - still within the normal gradient over much of the earth's land surface!

\section{Distribution}

Nonelectric use of geothermal energy implies that the low enthalpy fluid will be utilized directly as a thermal-energy source for applications such as space heating, greenhouse heat, and process heating. For any of these applications, a thermaldistribution network is required. Its cost can represent a major part of the total system cost. Data for Reykjavik, Iceland suggest the distribution system is $65 \%$ of the total energy costs (Zoega and Kristinsson, 1970). Among the factors which can influence the distribution cost are the source temperature, fluid velocity, soil and topographic conditions, accessibility for installing the 
network, load density within the distribution area, and distance 'of the source from the load area. The distribution of thermal energy in the form of steam or water by networks of insulated piping is called district heating. This it technique has been utilized for many years in several countries to provide thermal energy to individual and combined users. In most cases, the energy source has been fossil fuel. However, many of the operating practices are similar to those experienced in the relatively few instances where low-enthalpy geothermal energy is used. Among the countries where cities successfully utilize district heating are Austria; England, Finland, France, Germany, Iceland, Japan, New Zealand, Sweden; Switzerland, and the United States. As an example, in $1972 \mathrm{Malmo,} \mathrm{Sweden}$ had a total of 140-150 km of pipe in a two-pipe (supply and return) distribution system using fossil fuel as the energy source. The fluid is distributed at temperatures from $\mathbf{8 0}$ to $120^{\circ} \mathrm{C}$ in insulated pipe as largé as $800 \mathrm{~mm}$ in diameter and returns at 50 to $70^{\circ} \mathrm{C}$ : The energy is used for space heating in multi-story buildings and homes, in industry, and for ground heating and swiming pool heating. Sapporo, Japan; Bern, Switzerland; and Helsinki, Finland, are additional examples where thermal distribution systems have resulted in the successful use of low enthalpy water produced by fossil fuel to : provide space heating.

Iceland has an extensive district heating network, using low-enthalpy geothermal energy, operated by the Reykjavik District Heating Systém in and about the city of Reykjavik (Zoega and Kristinsson, 1970). This energy is ut1lized for space heating by a large majority of the city's approximately 80,000 residents and for greenhouse and multistory building heating. The system is primarily a single-pipe distribution network with the effluent discharged through the city drain system into the ocean. The climate in Reykjavik is very suitable for district heating since heating is required year around and the peak monthly load in January is only about 2.3 times the minimum monthly load in July. On the other hand, because of the large proportion of single-family homes, the load density of the system is rather low, being reported as $17 \mathrm{Gcal} / \mathrm{hr} \cdot \mathrm{km}^{2}$. Typical 1974 costs in Iceland sugge'st that a 14-inch insulated steel main costs about $\$ 150$ per metèr installèd and a single-house service line co'sts about $\$ 20$ per meter. The present "hook-up" charge is $\$ 600$ and typical héating cósts are approximately $\$ 200$ 
per year. At current (1974) oil prices, the corresponding heating costs would be approximately $\$ 800$ per year. Clearly, in this case, district heating systems using low-enthalpy geothermal energy are economically preferable. On a much smaller scale, cities in France and New Zealand successfully employ geothermal energy for space heating through distribution systems.

A thermal-distribution system is an assembly of piping which varies. in size throughout the system depending on the flow rates through the various branches. Also required are pumps, valves, regulators, meters, expansion joints, and controls necessary for reliable operation of the network. The system is generally thermally insulated (at least on the hightemperature supply line) to prevent excessive heat loss and temperature drop in the fluid. Due to viscous. friction losses, there is a continuous decline in the pressure along the: pipe; and, if the local elevation increases along the direction of flow, there is additional pressure decrease due to the loss of hydrostatic head. Conversely if the elevation degreases, the static head increases and tends to counteract the viscous pressure losses. In the majority of existing systems, therefore, pumps are necessary to maintain sufficient flow throughout the entire network and to prevent the pressure from dropping below a value which would result in local boiling. Surge tanks are generally necessary to prevent dramatic and potentially damaging changes in the pressure due to sudden changes or surges in the flow.

Because of the presence of certain impurities and entrained particulates, geothermal fluids can be corrosive and abrasive. The contents will vary from reservoir to reservoir, but $\mathrm{H}_{2} \mathrm{~S}, \mathrm{CO}_{2}$, chlorides, silica, bicarbonates, and entrained sand are among the impurities which have been observed in geothermal fluids. These impurities can cause any one or a combination of corrosion, erosioncorrosion, scaling, and erosion to occur, all of which can result in significant damage to pipe materials. Scaling will not necessarily cause leakage failure of the system but it can increase pumping requirements significantly as well as disrupt the performance of components such as heat exchangers. In contrast, chemical corrosion and/or mechanical erosion can cause actual pipe failure. In some areas, corrosion- and abrasionresistant materials may be necessary along with inhibitor additives, if their presence in the effluent is not prohibitive. Also, lining the pipe with special materials and placing 
hard, resistive materials in areas of high erosion may be considered. However, "since geothermal fluids are' typically in a réducing environment, corrosion has not proven to be as large an obstacle as might be expected. The Reykjavik district heating system uses steel pipe and it's performance has been satisfactory (Zoega and Kristinsson, 1970). The prectse corrosion problems which will be encountered in a future reservoir cannot be specified, but indications are that present technology can provide an acceptable solution.

Due to the elevated temperature of the fluid, allowance must also be made for axial expansions of steel pipe. Failure to do this can result in excessive stress which may cause failure in the pipe, anchors, or supports. Conventional expansion features such as bellows, slip-joints, and $\mathrm{U}$ - or Z-shape expansion joints have been shown to be adequate by practical experience. Conventionat. anchors, supports, and guides are also satisfactory.

Many different techniques for insulating and installing underground piping systems are utilized. These range from placing pipes within concrete trenches and conduits to the burial of prefabricated pipe. within a pipe with insulation between. Aväilable insulation such as calcium silicate, magnesia, polyurethane, mineral wool; and fiberglass can be used to reduce the heat loss to …"y acceptable limits, but consideration in selecting the type of installation and Insulation must be given to the particular terrain (e.g,, type of soil, local water table leve1) through which the piping passes. As a part of a solar total-energy study at Sandia Laboratories, Albuquerque, N.M., USA, a computer analysis to design and describe the operation of a distribution system for low-enthalpy water has' been performed. In this analysis the piping for a distribution system, which is of arbitrary size and which has a geometrically symmetric layout of the thermal load;' is designed using an allowable pressure drop and maximum pipe-velocity limitations. The pipe insulation type and thickness, and the geometry of the distribution network are specified. The heat loss, the temperature drop, the pressure drop, and the pump power are calculated for any specified thermal load. Cósts for all necessary components are included so that the distribution system costs can be determined.

The trends developed from these"; results illustrate the general type of application in which distribution systems may be economically acceptable 
for space heating. As expected, individual separated homes generally result in unfavorable economics compared to current fossil-fuel energy costs in the United States. This result can be attributed to two factors: first, the low energy density in the consumer area with a large amount of piping and the large associated heat loss, and second, the yearly load factor. If energy is required year around, as for example, in Iceland and other northernlatitude countries, the associated higher load factor results in lower costs per unit of energy. For latitudes in the United States, however, relatively constant highload factors are not typical of space heating requirements.

Multi-unit dwellings offer significant economic advantages, and results of analysis show that distribution systems can be similarly economically favorable. Units of 10 to 40 family-sized apartments were studied, and the larger units in particular can economically utilize distribution systems. In effect, these results show that energy cost is a strong function of the energy density in the area served. Similar results have been defined by others, in particular by Kohler (1973), for utilization of district heating in Sweden. For a community of individual homes in the U.S. in 1974, the distribution costs alone are calculated to add from $\$ 3$ to $\$ 4$ per MBtu to the energy costs, whereas multifamily units can be served by systems which will add less than $\$ 1$ per MBtu to the total energy costs. Other uses such as process heat for industrial use or greenhouse heating have not been investigated, but it seems reasonable to expect that the economics could be favorable because of the concentrated energy-use density and the expected high use load factor.

The heat losses through insulated distribution systems are generally only a small percentage of the useful heat which can be transmitted through the system. For a system of individual homes with a total piping length of approximately $50 \mathrm{~km}$, the energy loss from water initially at $100^{\circ} \mathrm{C}$ ranges from near $8 \%$ to approximately $20 \%$ of the energy available in the fluid, depending on flow rate and heat load. Also, the fluid temperature drops from 3 to $10^{\circ} \mathrm{C}$, again depending on the flow rate, while traversing approximately 3.2 kilometers of different sized, insulated piping from the source to the most distant user.

Likewise, the energy required to pump the fluid throughout the network is only a small percent of the thermal 
energy available in the fluid. For the $50 \mathrm{~km}$ distribution network referred to in the preceding paragraph, calculations show that the energy required to pump the fluid is on the average less than one percent of the thermal energy in the fluid. The Reykjavik system reports an installed pumping capacity of $1921 \mathrm{kw}\left(1.92 \times 10^{6} \mathrm{~J} / \mathrm{sec}\right)$ with a peak heating load of 2.21 $\times 10^{8} \mathrm{~J} / \mathrm{sec}$ and a total piping length of $289 \mathrm{~km}$. Thus, their peak pumping requirements represent on1y 0.87 percent of the energy which can be delivered on a peak basis. It seems clear, therefore, that properly designed thermal distribution systems can be operated routinely, with pump operation requiring no more than one percent of the energy which the system transmits.

There may be instances where the geothermal source is separated by several kilometers from a potential use. In that case, one is interested in knowing the thermal losses for different flow and temperature conditions as well as the costs. A typical supply main might be 18 inches in diameter and insulated piping of this size is estimated to cost in the U.S. in 1974 , from $\$ 200$ to $\$ 250$ per meter depending on the local installation conditions. For an 18inch diameter pipe insulated with 2-inches of urethane, the temperature drop as a function of length has been calculated for two flow rates and three inlet fluid temperatures with a soil temperature of $16^{\circ} \mathrm{C}$. For fluid velocities of 1.5 and 0.5 meters per second, representing full-load and partial-load flow conditions, inlet fluid temperatures of 150,100 , and $80^{\circ} \mathrm{C}$ were considered. Curves of fluid temperature as a function of length for these conditions are shown in Fig. 3. For 75 to $100 \mathrm{~km}$ of length, the fluid temperature undergoes significant reduction, particularly for the smaller flow rate. Thus consideration of the temperature required at the consumer and the varlation of load and flow rate must be given to determine the total length of piping main which can be satisfactorily utilized to transmit low-enthalpy fluid from a source to the consumer. In addition the pump power (which is linearly dependent upon length) required for the 1.5 meter per second flow would be $1200 \mathrm{kw}$ through a $100 \mathrm{~km}$ transmission system, whereas for the lower flow rate only $45 \mathrm{kw}$ are required. The larger pump requirements represent only about 5 percent of the energy which could be extracted from the flow with a $28^{\circ} \mathrm{C}$ temperature drop at the consumer. Pumping power is there- 


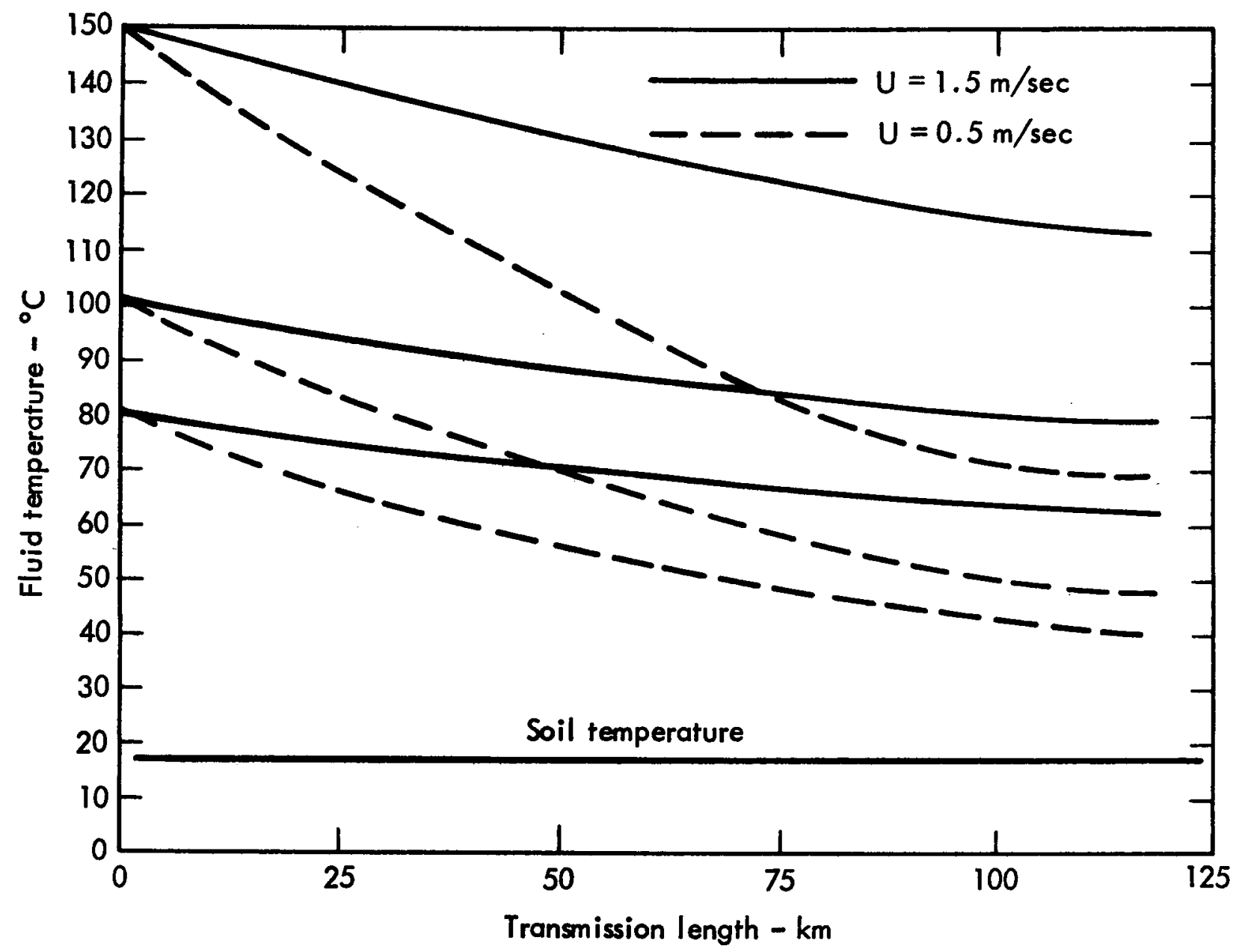

Fig. 3. Fluid temperature as a function of distance of transmission for an 18-in. diam pipe insulated with 2 in. of urethane. Soil temperature is $16^{\circ} \mathrm{C}$. For a flow rate of $1.5 \mathrm{~m} / \mathrm{s}$, which is thought to be representative of full load conditions, fluid-temperature fluid at $100^{\circ} \mathrm{C}$ at the starting point would drop to $80^{\circ} \mathrm{C}, 100 \mathrm{~km}$ downstream.

fore not excessive but several pumps spaced along the line would be required.

In summary, thermal distribution systems have been and are presently being successfully utilized. All of the technical and engineering experience necessary to design, construct, and install large insulated piping systems is available. All types of equipment necessary for reliable operation exist, and no technology innovations are necessary. Rather, the factors which have prevented a more widespread utilization of distribution systems are economic. In the past, most areas of the world have employed energy in a form which does not require thermal distribution systems, and energy in that form has 
been less expensive for space heating. However, in view of recent and. expected future changes in the world energy situation, in particular with regard to the availability and cost of fossil fuels, the prospect of utilizing thermal distribution systems in conjunction with basically inexhaustible energy forms such as geothermal appears much more promising,

USES

The wide variety of nonelectrical uses of geothermal energy can be seen from the following listing:

1. Residential and Commercial

a. Space heating and cooling

b. Water (potable, hot/cold utility, etc.)

c. Waste treatment (disposal, bioconversion, etc.)

d. Refrigeration

e. Deicing

2. Agriculture and Related Areas

a. Crops (greenhouses, hydroponics heated soil, etc.)

b. Animal husbandry (heating and cleansing needs of cattle, swine, chickens, etc.)

c. Aquatic farming (fish breeding, hatching, growing, etc.)

d. Processing of agricultural products (waste disposal or conversion, drying, fermentation, canning, etc.)
3. Industrial processes

a. Chemical próduction (ácids, fertilizer, fuel, etc.)

b. Pulp treatment

c. Mining (heat, water)

d. Drying (cement, clay, fish, etc.)

e, Water desalination/distillation

f. Mneral recovery from hydrothermal fluid

g. Waste treatment and disposal Note the following comments:

First, it is surprising, perhaps, to note that many nonelectrical applications throughout the world are the result of individual, not corporate, initiative. Many "do-it-yourselfers" are clever in appreclating the ways in which geothermal resources can be useful to them. There are numerous examples: New Zealanders sterilizing soil in order to realize increased success with horticultural hobbies; an automobile dealer in the United States heating his automobile agency from the "waste" discharge of a geothermally heated high school "upstream" of his agency.

Second, technologies which have been developed for other purposes may be transferred to certain nonelectrical applications of geothermal resources. There are numerous examples from the agricultural field. Studies which were organized to understand the effect of heating by fossil 
fuels on animal husbandry bear also on the use of geothermal resources. Likewise, understanding of adsorption refrigeration and freezing is applicable to any such system regardless of the heat source involved in that system. An awareness of these technologies on the part of those undertaking nonelectrical applications is called for.

Third, a comparison may be made between the heat energy used in a national energy budget and the temperature required for use of that heat. For the United States (and presumably for most other countries of the wor (d), many energy requirements can be satisfied, in principle, by geothermal resources of modest temperature. Figure 4 (Reistad, 1975) shows the amount of energy used in different segments of the U.S. national energy budget in 1968 as a function of temperature in $25^{\circ} \mathrm{C}$ increments. For the United States, $14.5 \times 10^{15}$ Btu of energy use can be satisfied by heat at temperatures less than $100^{\circ} \mathrm{C}$. Figure 5, which is a display of essentially the same information as Fig. 4 but in different form, shows cumulative energy use as a function of temperature. This figure shows that, were it available where needed, geothermal resources at temperatures less than $250^{\circ} \mathrm{C}$ could supply $50 \%$ of the total energy needs of the United States. Based on this sort of argument, it would appear that geothermal resources for nonelectrical uses have a promising future. However, the availability of the resource at places where it is needed or could be used is critical, and a comprehensive evaluation for this purpose for any nation has never been undertaken.

$$
\text { A final, general point about }
$$

geothermal resources and nonelectrical applications concerns a misconception. To date, geothermal resources have been available to users at very low costs. Some have felt, therefore, that if geothermal energy could be introduced into any manufacturing (e.g., tomato growing) service or system (e.g., freezing) requiring energy, the product so manufactured or service so supplied would be cheaper. This conclusion is true only if geothermal energy continues to be relatively inexpensive, and if the total value of the product or service is made up largely of energy costs. The latter qualification, i.e., large fraction of total cost lying in energy costs, is illustrated in Fig. 6. Certain nonelectrical uses for geothermal resources are energy intensive (e.g., district heating). Others are not (e.g., canning). Nonelectrical applications that are energy intensive should be 


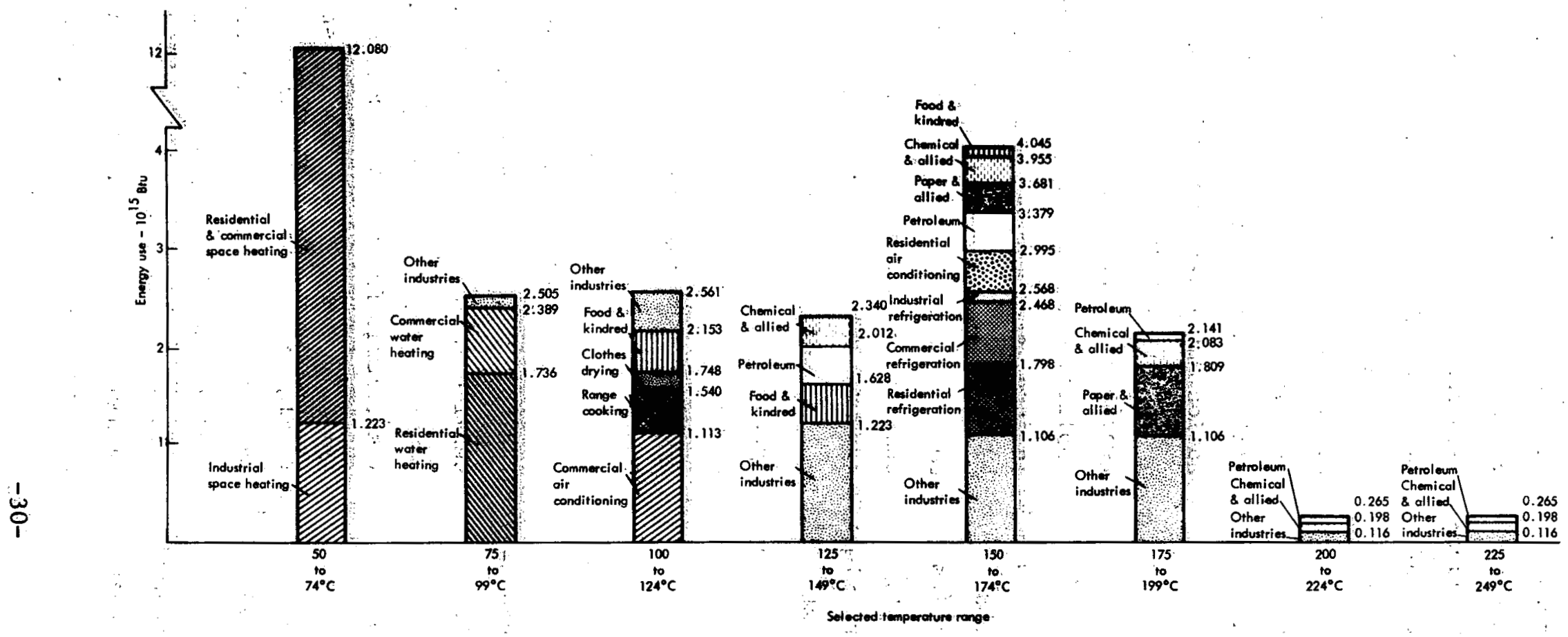

Fig. 4. Heating energy use in the United States in 1968. The number of BTU's of energy for different categories of use, e.g., industrfal space heating, is shown as a function of temperature. For example, 1.7 .36 $\times 10^{15} \mathrm{Btu}^{\prime} \mathrm{s}$ of energy in the temperature range of 75 to $99^{\circ} \mathrm{C}$ was used for residential water heating. The notation "chemical and allied," "food and kindred," etc. indicates process-steam usage in that sector. (Reistad, 1975) 


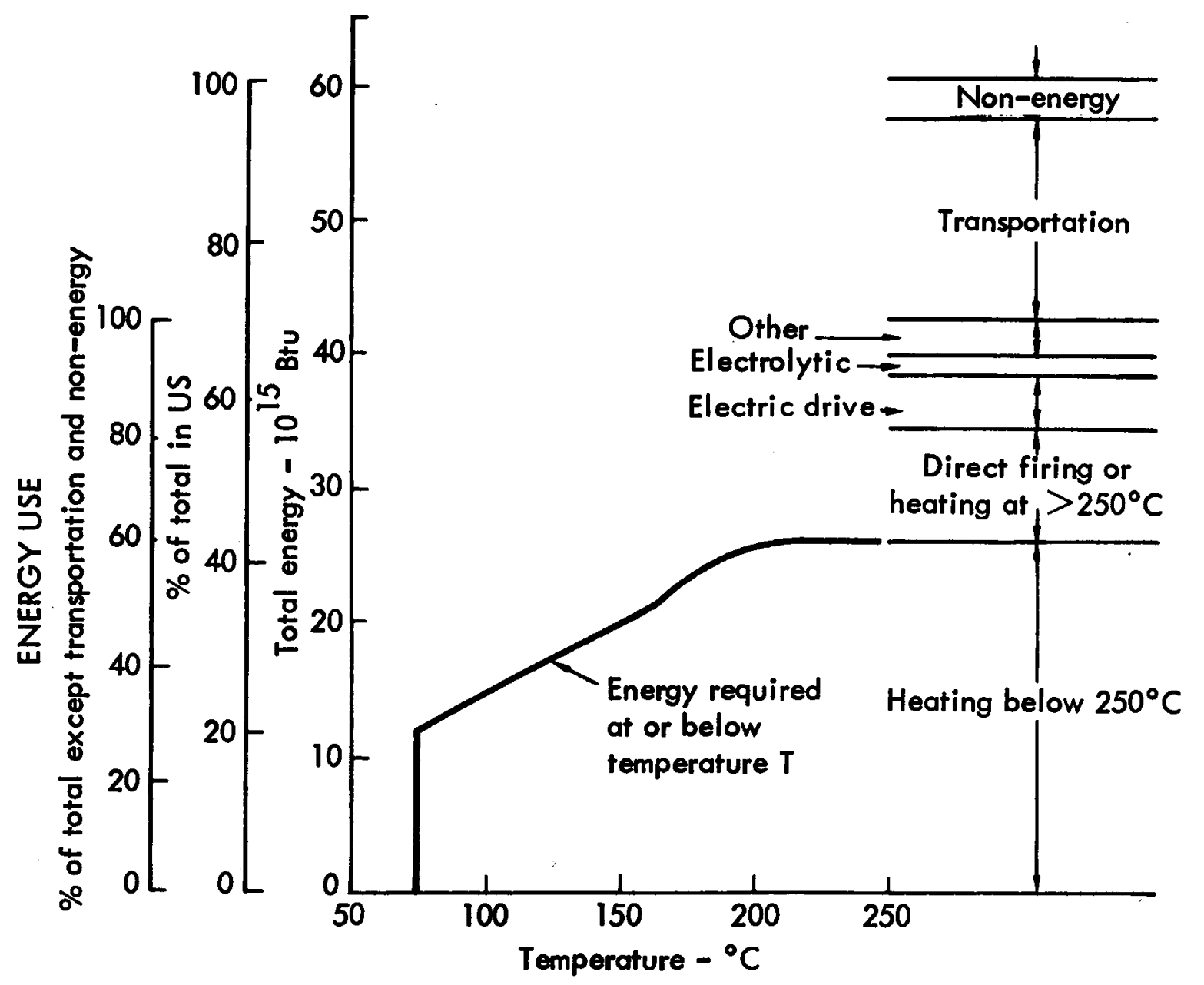

Fig. 5. Cumulative energy use as a function of temperature of heating, shown in relation to the total energy requirements in the Unites States in 1968. Energy at $100^{\circ} \mathrm{C}$ or less will satisfy, in principle, $25 \%$ of the total energy use and almost $40 \%$ of the total non-transportation energy use. Demand for energy in the range of $200^{\circ} \mathrm{C}$ to $<250^{\circ} \mathrm{C}$ is small. (Reistad, 1975)

advanced if geothermal is to become a significant component of the world's total energy budget.

\section{DISPOSAL OF GEOTHERMAL FLUIDS}

Disposal of geothermal fluids used in nonelectrical applications is not likely to be a trivial matter, owing to the sheer quantity of fluids
Involved in these applications. Unlike the production of electricity from high temperature steam (with its high calorific value), nonelectric applications will, for the most part, use the liquid form of water with its lower calorific value. Using $40^{\circ} \mathrm{C}$ as the nominal minimum practical discharge temperature and a typical 


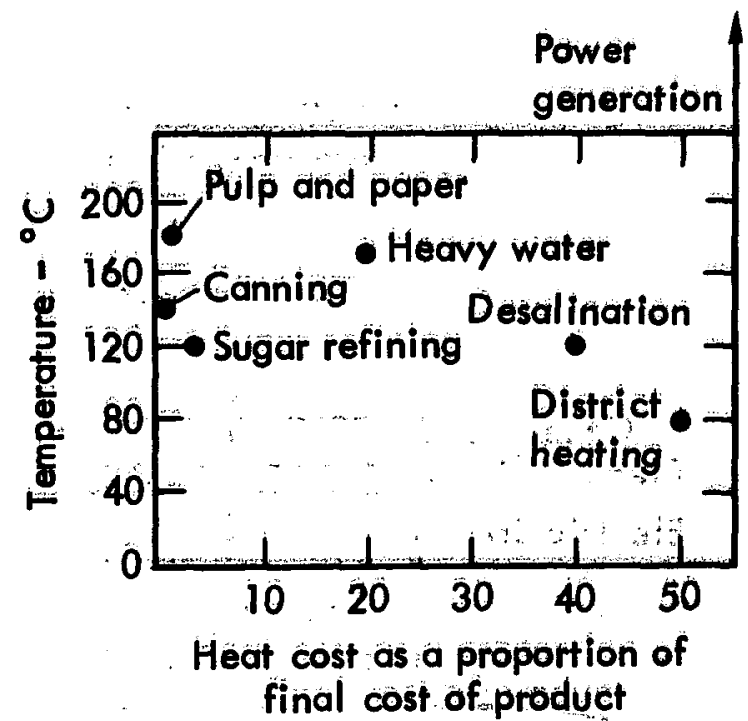

supply temperature of $100^{\circ} \mathrm{C}$, the calorific value of these flufds $1 \mathrm{~s}$ only about $12 \%$ that of steam. The quantity of fluid requiring disposal is hence a nominal order of magnitude greater than for many electric geothermal applications.

The effective disposal of geothermal fluids is a dual consideration: one of necessity and one of desirabil1ty. The necessity arlses because

\footnotetext{
* Those numbers should be considered only as giving a guide to the relative enormity of the disposal problem for nonelectric compared to electric applications. Considerable variation occurs in electric use. Wet cooling towers, for Instance, virtually eliminate the disposal problem (or substantially reduce its requirements) by evaporating much of the waste fluid. On the other hand, electric plants operating from hot water flelds (where flashing in the well is permitted) stlil bring large quantities of liquid to the surface.
}

Fig. 6. Heat-cost/total-cost ratio as a function of temperature for selected nonelectrical geothermal applications. The fraction of value of a product or service owing to cost of heat varies from a few percent (e.g., canning) to as much as 40 to $50 \%$ (e.g.,. desalination). District heating has relatively low temperature requirements but cost of heat represents $50 \%$ of the final cost of the servilce. (Lindal, 1973) the fluids are usually both too hot and too brackish for disposal in streams, estuaries or for agricultural use. The desirability arises because judiclous reinjection of fluid can minimize the problem of subsidence while also maintaining fluid pressure in the producing reservoir. The latter intention, however, has its concerns: namely, the possible cooling of the producing geothermal reservoir (Bodvarsson, 1972) and the possibility of activating faults.

For certain special cases, disposal may be, unnecessary or be ... relatively simple and environmentally acceptable. Down-hole heat exchangers are employed at Klamath Falls, Oregon, USA. In such cases, only the producing aquifer is affected. Abano; Italy, is an example in which both the salinity and the temperature are tolerable for environmentally 
acceptable surface disposal. Present environmental regulations in the United States, for instance, are such that the $\mathrm{H}_{2} \mathrm{~S}$ concentration, and the ambient stream discharge temperature requirements make the latter possibility a very rare option. The various aspects of geothermal fluid disposal are summarized in the following list:

1. Compatibility with Surface Waters

a. Salinity: Salinity exceeding $300 \mathrm{ppm}$ is undesirable; 1000 ppm considered tolerance limit for drinking water.

b. Temperature: Normal stream temperature plus a few degrees $C$ is often considered the limit in tightly regulated enviromental situation.

c. Gas content: $\mathrm{H}_{2} \mathrm{~S}$, high $\mathrm{CO}_{2}$, low oxygen are unacceptable depending on their levels of concentration.

d. Inadequate drainage capability: Is necessary if waste is to be rapidly carried to the ocean.

\section{Reinjection Advantages}

a. Helps to maintain fluid pressure in producing reservoir.

b. Helps to prevent subsidence.

c. Eliminates surface disposal concerns.
3. Reinjection Disadvantages

a. Cost of disposal wells.

b. Possible need for reinjection pumps and power to operate them.

c. Possibility of activating faults (Warner and Orcutt, 1973).

d. Possibility of cooling producing reservoir (Bodvarsson, 1972).

e. Possibility of chemical deposition blocking the pores of the formation in the reinjection region of the well (Otte, 1973).

The fluid as well as the heat should be considered a resource. It is implicit in this discussion that "disposal" is considered only after the resource is no longer "useful". If the water is pure enough to be desired by an irrigation district, for instance, then discharge of the water into the canals of that irrigation district is considered a use of the geothermal fluid, not disposal of it.

Methods used for disposal to date are varied. ilost commonly the nonelectrical applications have had tolerable salinity and temperature for surface disposal, consistent with local regulations. The consideration of gas content has often not 
been of major importance. Table 3 i.ists methods for disposal of fluids from a selected number of the major app1ications of geothermal energy worid-wide. One should not conclude that this ilsting impiles that similar approaches would be desirable or acceptable in different environmental settings.

Perhaps the most noteworthy example of disposal by reinjection is that being employed at a commercial

Tabie 3. Some methods currently in use for disposai of geothermal fluids.

\begin{tabular}{|c|c|c|}
\hline Locat lon & Disposal method & Comments \\
\hline \multicolumn{3}{|c|}{ Electric geothermal power plants } \\
\hline Geysers, U.S.A. & $\begin{array}{l}\text { Reinjection in less } \\
\text { productive steam } \\
\text { wells (Finney, 1973) }\end{array}$ & $\begin{array}{l}\text { About } 1 / 3 \text { of steam plant } \\
\text { condensate reinjected } \\
\text { (Budd, 1973) }\end{array}$ \\
\hline Lardarello, Itäly & Surface disposal & $\begin{array}{l}\text { Minimal disposal need; } \\
\text { steam condensate recycled }\end{array}$ \\
\hline Watrake1, New Zealand & Disposal to river & \\
\hline Japan & $\begin{array}{l}\text { Mostly by reinjection; } \\
\text { some disposai to steams } \\
\text { and ocean. }\end{array}$ & . . \\
\hline Cerro Prieto, Mexico & Surface pond & $\begin{array}{l}\text { Man-made pond with } \\
\text { natural, rapid evaporation }\end{array}$ \\
\hline \multicolumn{3}{|c|}{ Nonelectric geotherma 1 uses } \\
\hline Hungary: space heating & $\begin{array}{l}\text { Surface disposal to } \\
\text { streams or lakes }\end{array}$ & $\begin{array}{l}\text { Lake disposal recently } \\
\text { restricted. }\end{array}$ \\
\hline $\begin{array}{l}\text { New Zealand space } \\
\text { heating and cooling }\end{array}$ & $\begin{array}{l}\text { Surface disposal to } \\
\text { streams, lakes, and sea. }\end{array}$ & Most water of low salinity \\
\hline Reÿkjavik & $\begin{array}{l}\text { Via municipal sewerage } \\
\text { system to ocean. }\end{array}$ & . \\
\hline $\begin{array}{l}\text { Melun, France: space } \\
\text { heating }\end{array}$ & Reinjection & $\therefore:-$ \\
\hline $\begin{array}{l}\text { Abano, Italy: } \\
\text { spas, balneology }\end{array}$ & $\begin{array}{l}\text { Súrface stream } \\
\text { disposal }\end{array}$ & Low salinity fluid \\
\hline $\begin{array}{l}\text { Boise; Idaho, U.S.A.: } \\
\text { space heatIng }\end{array}$ & To municipal sewer & $\begin{array}{l}\text { Special sewer usage tax } \\
\text { assessed }\end{array}$ \\
\hline $\begin{array}{l}\text { Raft River, Idaho: } \\
\text { greenhouse space } \\
\text { heat lng : }\end{array}$ & $\begin{array}{l}\text { To agricultural } \\
\text { frigation canal } \\
\end{array}$ & $\begin{array}{l}\text { Some adverse mineral } \\
\text { degradation of land } \\
\text { observed. }\end{array}$ \\
\hline $\begin{array}{l}\text { Klamath Falls, } \\
\text { oregon: heat ing }\end{array}$ & $\begin{array}{l}\text { No fluid to be } \\
\text { disposed }\end{array}$ & Down-hole heat exchangers \\
\hline
\end{tabular}


geothermal heating installation of an apartment house complex $(3000$ units) at Melun, France (40 miles southeast of Paris). In this installation, the production and reinjection wells were drilled to approximately the same depth, starting from surface locations only a few meters apart. The drilling method involved application of "whipstocking" on both wells, so that in the producing strata the well bores were nearly at a 1000 meter separation distance. Well depth is approximately 1800 meters (P. Maugis, 1973).

Several experimental tests of reinjection have been conducted in the Imperial Valley of California. These have been designed to test the feasibility of reinjection of highly brackish waters. Most of the data are still proprietary (Otte, 1973).

For future major applications of geothermal fluids for nonelectric uses, it would seem that the following general conclusions might be valid:

1. Quantities of fluid to be handled will likely be in the range of 1000 liters/sec per $100 \mathrm{MW}$ of useful thermal energy.

2. Surface disposal may be considered if: a. The fluid is of low salinity $(<1000 \mathrm{ppm})$

b. The spent fluid is cool $\left(<40^{\circ} \mathrm{C}\right)$

c. The discharge reservoir (lake, pond, stream, or estuary) capacity or flow greatly exceeds the geothermal fluid flow

d. The $\mathrm{H}_{2} \mathrm{~S}$ content is negligible or the $\mathrm{H}_{2} \mathrm{~S}$ is first offgased and appropriately discharged to the atmosphere

e. The natural recharge capability of the geothermal reservoir is approximately the same as the rate that fluids are being withdrawn.

3. Reinjection of the fluid into deep wells will generally be the preferred or required mode of disposal. This involves technical and funding problems concerning the number of wells needed, the necessity of pumps, and the monicuring of the process for induced seismic activity, etc.

4. Extraction of heat directly from the reservoir could eliminate the disposal problem. Two such possibilities are down-hole heat exchangers and allowing only steam to reach 
the surface (the latter substantially minimizes the disposal problem).

Cost of disposal when reinjection is required is a major item of concern. The number of reinjection wells required will vary depending on the circumstances; and in general, one might anticipate the need for fewer reinjection wells than production wells, perhaps in a ratio of 1 to 2. Fluid can be forcibly reinjected using surface pumps, as needed. Certainly, where possible, one would utilize natural hydrostatic density differences of hot and cold legs to provide a major portion of the pumping power. Evien so, natural pressure differences for reinjection can certainly be enhanced by surface pumps less expensively than one can dr111 additional wells.

The depth and location of reinjection wells are another concern. There are at least five approaches that have been suggested or employed.

a. Reinjection into the same strata, but sufficiently "upstream" from the production wells to allow for natural heating of the water in the transit distance.

b. Reinjection in the same strata but "downstream" from the production wells. This method allows for the maintainence of fluid pressure but does not require that nature reheat the reinjected fluid for later withdrawal from production wells.

c. Reinjection at a lesser depth

.1: than the production wells, at the top of the reservoir, with little lateral displacement between wells.

d. Reinjection at a greater depth than the production wells. This method is perhaps more attractive than (c) above, because the deep wells need only be about half the number of the shallower wells.

e. Reinjection into an entirely different strata and reservoir. One must be certain the strata is not in close communIcation with a domestic water aquifer (Warner and Orcutt, 1973). This approach probably creates more geologicalhydrologlcal complexities than either of the four preceding methods.

In summary, the cost of disposing of the geothermal fluid for future nonelectric applications will generally be more than a trivial part of the project cost. Reinjection is 
the most 1ikely method to be employed, and also the most expensive. Though these statements are not meant to discourage the application of geothermal energy to nonelectrical uses, the potential user should be aware that environmental as well as practical considerations involved in a major geothermal project will generally require significant expenditures for reinjection or disposal of the waste geothermal fluid.

\section{Applications}

RESIDENTIAL AND COMMERCIAL APPLICATIONS

Introduction

In residential and commercial establishments, energy is consumed for a multitude of purposes such as space heating and cooling, water heating, lighting, refrigeration, cooking, clothes drying, etc. The uses requiring high-quality thermal energy, such as lighting, mechanical drives and fast-response cooking are best satisfied by electricity or by direct burning of fossil fuels. On the other hand, space and water heating as well as drying require relatively low temperature-levels and are therefore very suitable end uses for geothermal energy. Space cooling and some types of refrigeration are further promising end uses.

The amount of energy consumed in residential and commercial applications is a significant fraction of the total energy consumption. In the U.S.A. the energy consumed for space heating alone represents about $18 \%$ of the total national consumption, while water heating, space cooling and refrigeration consume an additiona1 $7.5 \%$. In some rather extreme cases such as Denmark, space heating accounts for about $43 \%$ of the total national energy consumption.

Recent substantial increases in the price of fossil fuels have prompted a growing interest in the application of geothermal energy wherever suitable sources and markets are available. Space heating and other residential uses are perhaps the most promising field for application of geothermal energy.

\section{Geothermal Resources}

for Low-Temperature Utilization

Practically any geothermal source can be utilized directly or indirectly for space heating and other low temperature uses provided fluids with temperatures above $40^{\circ} \mathrm{C}$ are available. It is convenient to refer 
to mainily two types of sources:

Those above $150^{\circ} \mathrm{C}$ (high temperature)

and those below $150^{\circ} \mathrm{C}$ (low

temperature)

The high-temperature sources are generaliy of volcanic assoctation and are found in active regions such as the Circum-Pacific Belt, the African Rift Zone and in Iceland: In some areas; source temperatures up to almost $400^{\circ} \mathrm{C}$ are available. Such sources are primárily coñsidered for the generation of electrical power, and space heating is mainly a byproduct utilizing effluent waters. Low-temperature sources are essentially of two types:

- Resources of direct or marginal volcanic association which are found in great numbers in the active regions mentioned in the previous paragraph. The many low-temperăture resources of Iceland (Bodvarsson and Einarsson, 1964) provide a very good example of the wide varlety of temperatures and potential available.

- Low-temperature resources of nonvolcanic origin of which the following are the most prominent cases: (1) The geopressured sources of the Northern Gulf of Mexico Basin (Jones, 1970) with temperatures of $100^{\circ} \mathrm{C}$ to $150^{\circ} \mathrm{C}$ and wellhead pressures up to
500 atmospheres. (2) The thermal resources of the porous sediment's of Hungary (Boldizar, 1970) with temperatures of $80^{\circ} \mathrm{C}$ to $100^{\circ} \mathrm{C}$.

(3) Sources of similar nature in the Soviet Union, that is, in southern Rúsía and western Siberia; which appear to be of imménse extent and magnitude (Tikhonov and Dvorovi, 1970). (4) Less extensive sources of this kind which are known in the Paris Basin in France (Maugls, 1969). The investigation of the non-volcanic sedimentary thermal water resources is in its very beginning. A great number of further sources of this kind càn be expected to be found.

Totally stimulated dry-hot-rock resources are likely to become of considerable importance as sources of low-temperature geothermal energy for space heating (Bodvarsson, 1974). The development of this field is of particular interest, since such resources are likely to be available in great abundance.

\section{Technoeconomics of Geothermal} Space Heating

The temperature range for comfort conditions is about $17^{\circ} \mathrm{C}$ to $25^{\circ} \mathrm{C}$ for most residential and commercial spaces. Although it is technically feasible to use geothermal fluids 
only slightly above this temperature for heating, both the heating equipment and flow rates of geothermal fluid become uneconomically large if this temperature range is too closely approached. llany present applications use waters in the range of $60^{\circ} \mathrm{C}$ to $90^{\circ} \mathrm{C}$ while some use waters at temperatures as $10 \mathrm{w}$ as $40^{\circ} \mathrm{C}$. In general, the higher the temperature the lower the transportation and distribution costs per unit of heat unless higher temperatures complicate the system design.

Economics and Load Characteristics.

The maximum power and the annual energy consumption are the two main design parameters of a given space heating system. The maximum heating power required for a unit surface area of a heated space depends mainly on the effective maximum insideoutside temperature differential, total wall conductance and heat losses due to ventilation and leakage. The yearly average power, and therefore the yearly energy consumption, depend on the yearly average inside-outside temperature differential, or, in other words, on the number of "degreedays" per year. The ratio between the maximum and the average temperature-differential gives a measure of the yearly load factor. The capital costs of a heating system depend primarily on the maximum power and type of system, whereas the annual fuel expenditures are given by the annual energy consumption. The total yearly costs are a sum of the fixed capital costs and the fuel costs.

The number of degree-days per year is to a considerable extent a function of the latitude. The effective maximum inside-outside temperature differential is also latitude dependent, but to a lesser extent. Data on degree-days per year for the U.S.A. and Canada are given in Fig. 7 .

From the economical point of view, the principal difference between conventional individualhouse fuel-fired heating systems and geothermal systems is that the latter type is usually operated on the basis of heat supply from large, fairly concentrated geothermal resources. The geothermal system is typically a district heating system with a large amount of therma.1-water or - steam-transmission equipment. Such systems are consequently considerably more capital intensive than the conventional individual-house heating systems. On the other hand, geothermal district heating systems have no, or only, minimal fuel expenditures. The economy of geothermal heating systems relative to individual fuel- 


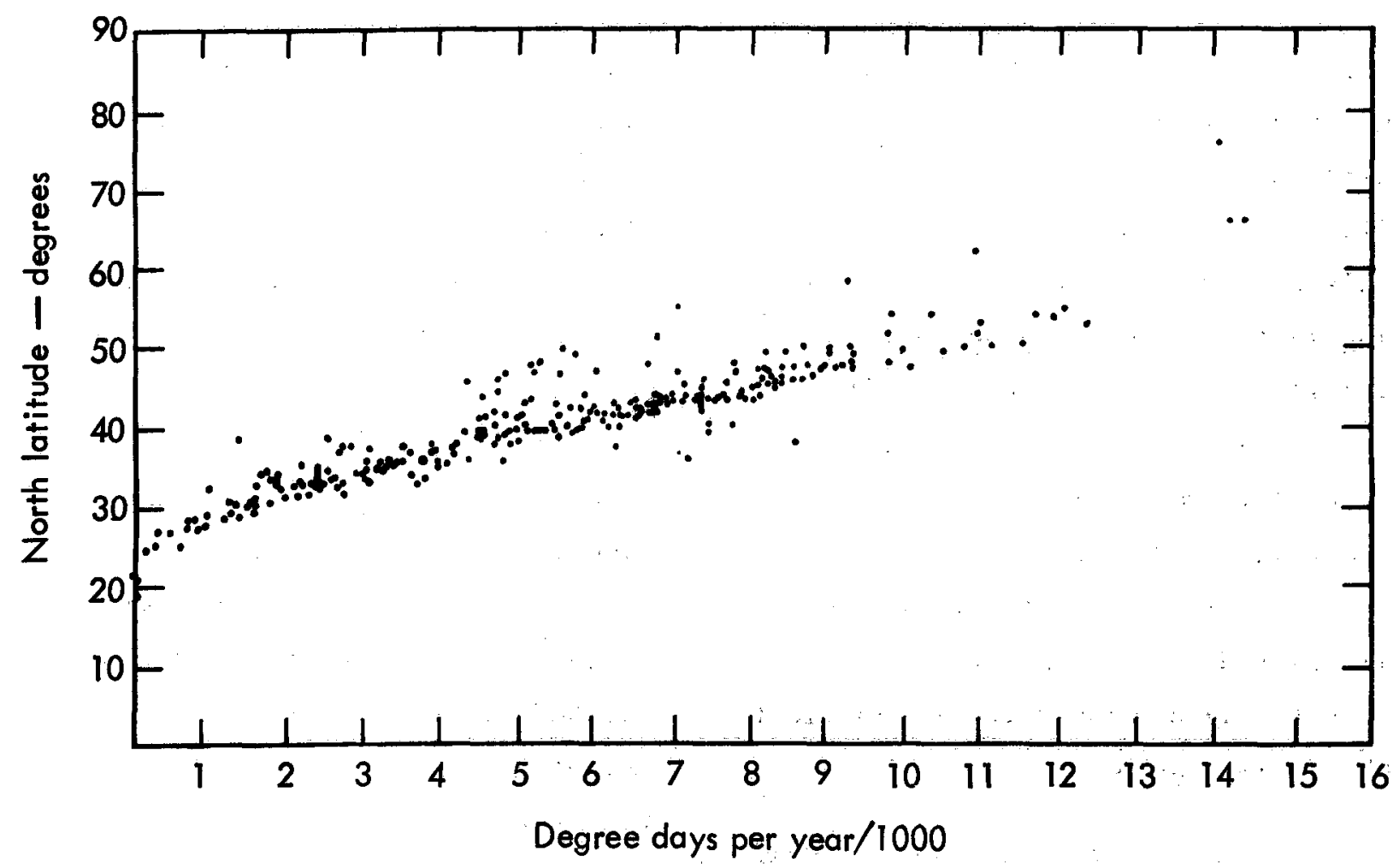

Fig. 7. Degree days per year as a function of latitude for the United States and Canada, Values from America Society of Heating, Refrigeration and Air Conditioning Engineers Handbook. Base temperature is $18.7^{\circ} \mathrm{C}$.

fired systems is therefore to a considerable extent dependent on the yearly number of degree-days, that is, latitude, and on local costs of fossil fuel. A qualitative comparison of the economics of the two types of heating systems is given in Fig. 8. Geothermal space heating systems are most economical in regions at high latitudes with high load factors and high costs of fossil fuel.

In designing geotherma1 heating systems, mainly in locations with highly varying ambient temperatures, it is of interest to enhance the yearly load factor by suppressing the required effective maximum temperature differential. This can be achieved by enhancing the thermal capacitance of buildings. Massive walls with insulation on the outside and the use of fuel-fired peak-load booster plants are of economical advantage.

Conversion to Geothermal Heating.

Since many potential applications are for existing cities, the ease of converting to a geothermal system within the buildings is an important 


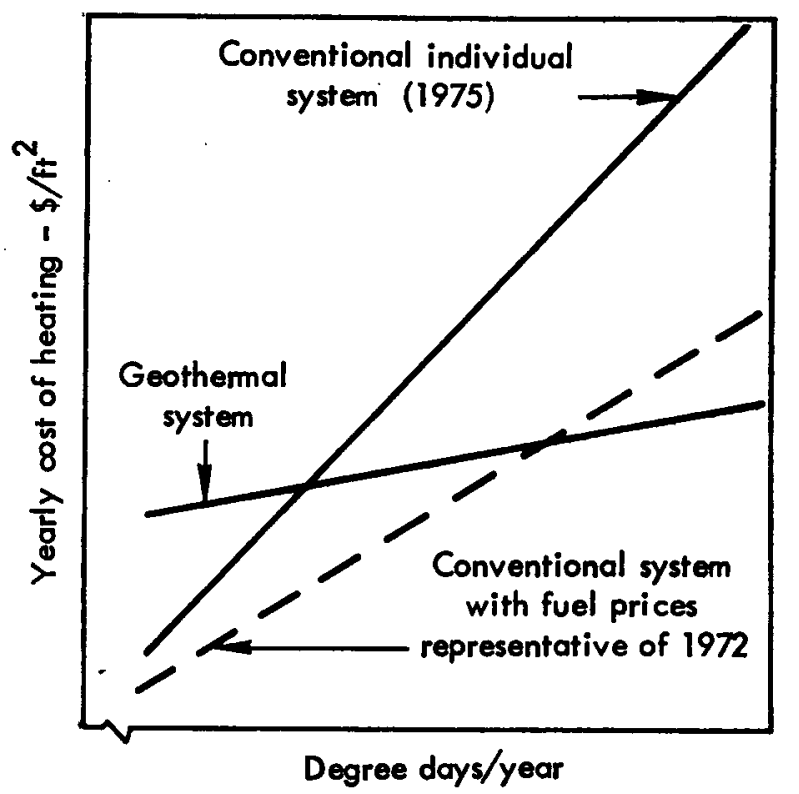

Fig. 8. Qualitative comparison of the economics of geothermal district heating systems and conventional individual systems, as a function of the number of degree days per year. Higher numbers of degree days per year and a higher fuel prices tend to make geothermal systems more economically appealing.

consideration. The two most common types of residential heating systems, warm or hot water systems and forced air systems can quite readily be adapted to the use of geothermal energy. The warm or hot water system that uses radiators or convectors can be adapted by (1) Using the geothermal fluid in the equipment, provided no corrosion or scaling problems are encountered, or (2) Using a binary-fluid surface heat exchanger system in which scaling and corrosion are controlled.

In forced-air systems, the temperature of the hot air leaving the heating equipment is usually around 55 to $60^{\circ} \mathrm{C}$. The air can thus be heated with the geothermal fluid in a surface heat exchanger provided geothermal fluids with temperatures at or above the 70 to $80^{\circ} \mathrm{C}$ are available. Thus, with the replacement of the furnace and present fan with a surface heat exchanger and possibly a somewhat larger fan, the adaptation would be complete. For lower temperature geothermal fluids, a heat pump may be required to yield temperatures that are high enough to allow use of the present air delivery system in the building.

Transportation and Distribution Costs.

This portion of the cost of the geothermal energy is primarily dependent on (1) The size of the market, (2) The temperature difference that can be effected in the fluid, (3) The load density of the market, (4) The distance from the geothermal field to the market, and (5) The complexity of the system required for distribution and disposal.

The size of the heating market is important because for large markets, advantage can be taken of economy of scale, particularly on the main pumping station and the transportation 
Iines between the geothermal field and the market. The temperature difference that can be effected in the fluid is inversely proportional to the required flow rate of fluid for a given market. A doubling of the temperature difference halves the flow rate, and for a constant velocity in the pipe, decreases the pipe diameter to 0.7 of its original value. The distance from the geothermal field to the market significantly affects the transportation cost and for distances greater than a few kilometers, this cost is directly proportional to the distance.

The density of the heating market is the major factor that determines the distribution costs per unit of area for a given type of system. 'In the U.S.A., single-family housing does not provide a dense enough heating requirement to economically permit district heating, while apartments (10 to 40 family units) do provide a dense enough market: On the other hand, single-family dwellings are being served economically by, for example, the district heating system in Reykjavik, Iceland," where the annual load factor is quite good and fuel costs have been somewhat greater than in the U.S.A.

The design of the system influences both the transportation and the distribution costs. For example; in the Reykjavik system, where some parts of the system are of a single-pipe design while others are two pipe, the single pipe system costs are only about $70 \%$ of that for the two pipe system (Zoega, 1974).

Zoega (1.974) presents costs of the Reykjavik system based on replacement cost in 1974 , as shown in following summary:

Production cost $\quad 0.080 \mathrm{c} / \mathrm{kWh}$

Transportation cost $\quad 0.101 \mathrm{c} / \mathrm{kWh}$

Distribution cost $0.350 \mathrm{c} / \mathrm{kWh}$

Total cost $0.531 \mathrm{c} / \mathrm{kWh}$

This total of $0.53 \mathrm{c} / \mathrm{kWh}$ compares very favorably with the following listing of costs for other energy sourcés (Zoega; 1974):

District heating (geothermai) $0.53 \mathrm{c} / \mathrm{kWh}$ Light fuel oil $2.18 \mathrm{c} / \mathrm{kWh}$ Heavy"fuel oil $1.04 \mathrm{c} / \mathrm{kWh}$ Electricity $1.44-2.91 \mathrm{c} / \mathrm{kWh}$

Surplus electricity (night rate)

$0.91 \% / \mathrm{kWh}$

In the U.S.A.; work In waste heat utilization (Reistad, et. al, , 1974) shows that a system which uses $150^{\circ} \mathrm{C}$ water heated with extraction steam from a thermal-electric power plant can economically provide heating and air conditioning to a city with 130,000 'residents in apartments'; located at distances up to a maximum. of $35 \mathrm{~km}$ from the power plant. 


\section{Scaling and Corrosion.}

The tendency of some geothermal fluids to cause scaling and corrosion of common heating equipment is a governing factor for the type of system that can be used. Generally, fluids with a low tendency for corrosion or scaling can be used directly in the heating equipment within buildings. Fluids that are more "aggressive" must be used in a surface-heat exchanger to heat a secondary fluid for circulation in the heating equipment. In extreme cases of scaling, the technology for economical ways in which to deal with the fluids is still lacking. Mashiko and Hirano (1970) report on the use of various types of pipes laminated with synthetic materials in order to avoid corrosion problems from mineralized water.

The composition of the geothermal waters is very dependent on the reservoir conditions where the fluids are generated. Furthermore, slight changes in minor consituents can significantly alter the corrosion and scaling rates. At this time, when a large development is planned, corrosion and scaling tests with the specific fluid are recommended. Experience in Iceland (Bodvarsson, 1950) has shown that scaling from siliceous materials is uncommon when reservoir temperatures are below $100^{\circ} \mathrm{C}$, but may present a major problem when the water is from high-temperature reservoirs. Also, exclusion of atmospheric oxygen from high temperature waters is a primary step in avoiding corrosion. Moreover, it was found that the resistivity of the water can be an indication of the aggressiveness of the fluid.

Hermannsson (1970) has recently reported on the scaling and corrosion in the Reykjavik system. Marshall and Braithwaity (1973) report on corrosion control in geothermal systems.

Environmental and Social Aspects. The overall influence that environmental constraints and social aspects will have on the use of geothermal energy for district heating are just beginning to be evaluated. The geothermal district heating developments to date have not been subject to the recent quite stringent environmental regulations such as exist in the U.S.A.; and new systems will face strict constraints. For instance, it is clear that single-pipe systems that use geothermal water and dump to a drain will meet with very little favor in such countries.

The task of finding the proper financing of district heating systems is a major obstacle to their development in some countries. In the U.S.A. for example, district heating systems 
Table 4 . Present residential and commercial applications of geothermal energy.

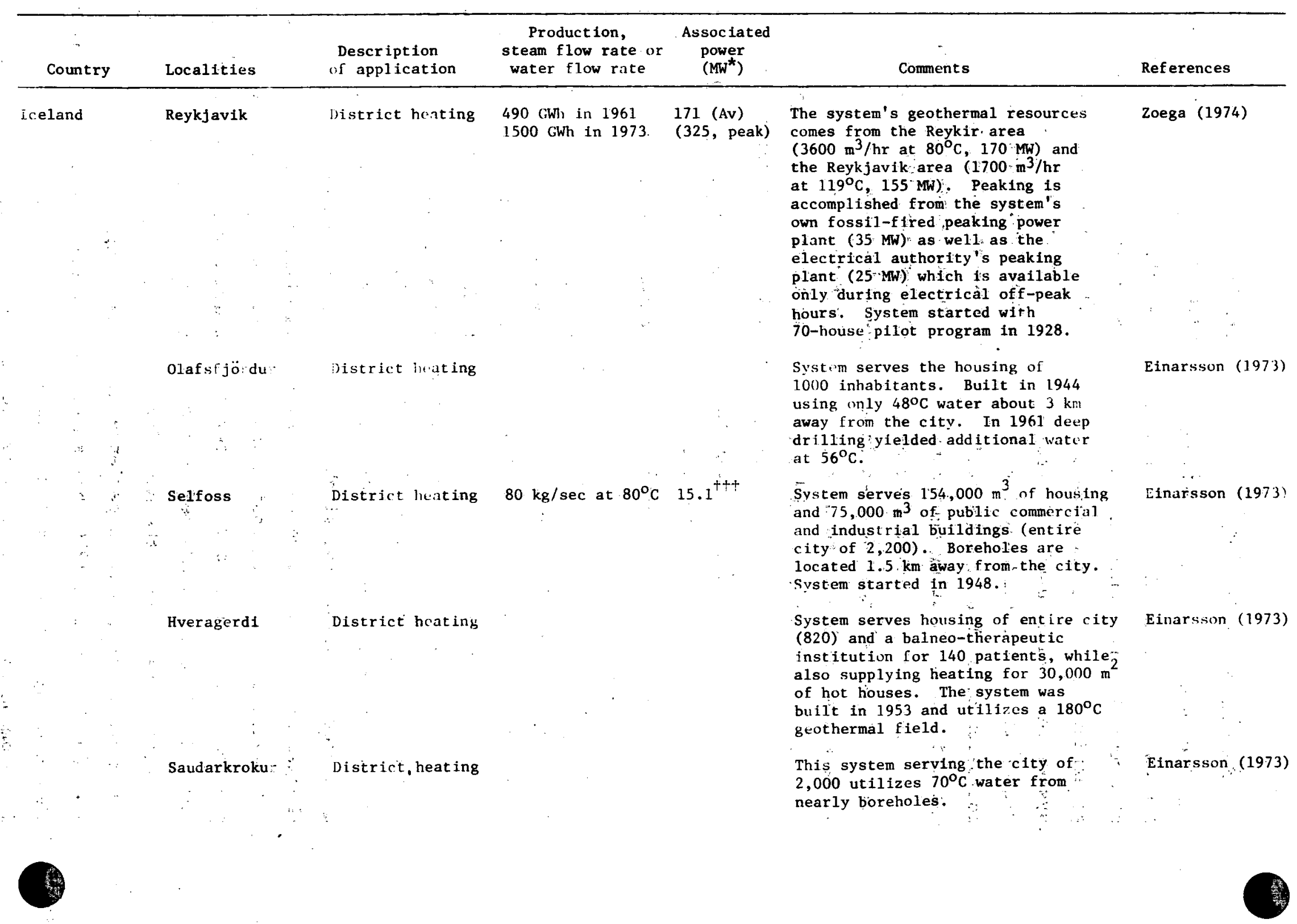


Table 4. (cont)

\begin{tabular}{|c|c|c|c|c|c|c|}
\hline Country & Localities & $\begin{array}{l}\text { Description } \\
\text { of application }\end{array}$ & $\begin{array}{l}\text { Production, } \\
\text { steam flow rate or } \\
\text { water flow rate }\end{array}$ & $\begin{array}{l}\text { Associated } \\
\text { power } \\
\left(M^{*}\right)\end{array}$ & Comments & References \\
\hline \multirow[t]{2}{*}{ United States } & Boise, Idaho & District heating & $\begin{array}{l}53 \mathrm{~kg} / \mathrm{sec} \text { at } 77^{\circ} \mathrm{C} \\
\text { (maximum capacity) }\end{array}$ & $9.2^{++t}$ & $\begin{array}{l}\text { This system, which continues to } \\
\text { serve about } 200 \text { houses and } 10 \text { to } \\
12 \text { businesses }(1970) \text {, is one of } \\
\text { the oldest district heating } \\
\text { systems. It was built during } \\
\text { the } 1890^{\prime} \text { s. }\end{array}$ & We11s (1971) \\
\hline & $\begin{array}{l}\text { Klamath Falls, } \\
\text { Oregon }\end{array}$ & $\begin{array}{l}\text { Individual space } \\
\text { heating of homes } \\
\text { and businesses }\end{array}$ & $49 \mathrm{GWh}$ & 5.6 & $\begin{array}{l}\text { Space heating of homes is generally } \\
\text { accomplished with several home- } \\
\text { owners sharing a well and using } \\
\text { downhole heat exchange systems. } \\
\text { Presently } 468 \text { residences are } \\
\text { heated geothermally. Some com- } \\
\text { mercial installations withdraw the } \\
\text { geothermal fluld, use it in heat } \\
\text { exchangers and discharge the waste } \\
\text { water to the sewer system or some } \\
\text { discharge area. }\end{array}$ & Lund et a1. (1974) \\
\hline \multirow[t]{5}{*}{ U.S.S.R. } & Makhach-Kala & & $\begin{array}{l}23 \mathrm{~kg} / \mathrm{sec} \text { at } 63^{\circ} \mathrm{C} \\
\text { plus } 70 \mathrm{~kg} / \mathrm{sec} \\
\text { plus others. }\end{array}$ & $=12.6^{t+\dagger}$ & $\begin{array}{l}\text { Several districts are supplied, } \\
\text { one of which has } 15,000 \\
\text { inhabitants. }\end{array}$ & $\begin{array}{l}\text { Lokchine and } \\
\text { Dvorov }(1970)\end{array}$ \\
\hline & $\begin{array}{l}\text { Zgoudidi town, } \\
\text { Georgia }\end{array}$ & District heating & $50 \mathrm{Gcal} / \mathrm{hr}$ & 58.1 & & $\begin{array}{l}\text { Lukchine and } \\
\text { Dvorov }(1970)\end{array}$ \\
\hline & Mend $j i$, Cieorgia & $\begin{array}{l}\text { Heating of } \\
\text { meteorologic } \\
\text { station and agri- } \\
\text { cultural uses }\end{array}$ & 2.0 Geal/hr & 2.3 & & $\begin{array}{l}\text { Lokihine and } \\
\text { Dvorov }(1970)\end{array}$ \\
\hline & Zalchl, Georgia & $\begin{array}{l}\text { Heating of } \\
\text { meteorologic } \\
\text { station, hot- } \\
\text { houses and baths }\end{array}$ & $2.1 \mathrm{Gcal} / \mathrm{hr}$ & 2.4 & & $\begin{array}{l}\text { Lokchine and } \\
\text { Dvorov }(1970)\end{array}$ \\
\hline & $\begin{array}{l}\text { Iserback town } \\
\text { Daghestan }\end{array}$ & District heating & $6(i c a l / h r$ & 7.0 & $\begin{array}{l}\text { Heating for } 7,500 \text { inhabitants and } \\
\text { industrial uses. }\end{array}$ & $\begin{array}{l}\text { Lokchine and } \\
\text { Dvorov }(1970)\end{array}$ \\
\hline
\end{tabular}


Table 4. (cont)

\begin{tabular}{|c|c|c|c|c|c|c|}
\hline Country & Localities & $\begin{array}{c}\text { Description } \\
\text { of application }\end{array}$ & $\begin{array}{l}\text { Production, } \\
\text { steam flow rate or } \\
\text { water flow rate }\end{array}$ & $\begin{array}{l}\text { Associated } \\
\text { power } \\
\left(\mathrm{MW}^{\star}\right)\end{array}$ & Comments & References \\
\hline \multirow[t]{3}{*}{ U.S.S.R. (cont) } & $\begin{array}{l}\text { Caspillsk town } \\
\text { Daghestan }\end{array}$ & $\begin{array}{l}\text { District heating } \\
\text { and hot water } \\
\text { supply. }\end{array}$ & $5 \mathrm{Gcal} / \mathrm{hr}$ & 5.8 & & $\begin{array}{l}\text { Lokchine and } \\
\text { Dvorov (1970) }\end{array}$ \\
\hline & $\begin{array}{l}\text { Para tounka } \\
\text { Ramchatka }\end{array}$ & $\begin{array}{l}\text { Heating of } \\
\text { apartments }\end{array}$ & $0.55 \mathrm{Gcal} / \mathrm{hr}$ & 0.64 & $\begin{array}{l}\text { Three apartment buildings of } 48 \\
\text { apartments each }\end{array}$ & $\begin{array}{l}\text { Lokchine and } \\
\text { Dvorov (1970) }\end{array}$ \\
\hline & $\begin{array}{l}\text { Cherkesk } \\
\text { Stavropol }\end{array}$ & $\begin{array}{l}\text { District heating, } \\
\text { industrial uses, } \\
\text { and hothouses. }\end{array}$ & $22 \mathrm{Gcal} / \mathrm{hr}$ & 25.6 & $\begin{array}{l}\text { Heating for } 18,200 \text { inhabitants, } \\
\text { plus industrial uses and hothouses. }\end{array}$ & $\begin{array}{l}\text { Lokchine and } \\
\text { Dvorov, (1970) } \\
\qquad\end{array}$ \\
\hline New Zealand & Rotorua & $\begin{array}{l}\text { Individual space } \\
\text { heating of homes } \\
\text { plus space cooling } \\
\text { of a business. }\end{array}$ & , & & $\begin{array}{l}\text { Over } 700 \text { geothermal bores serving } \\
\text { many individual applications. } \\
\text { City consists of seven areas, three } \\
\text { of which halve approximate } 1 \mathrm{y} 80 \text { bores } \\
\text { at a useful average of } 2 \times 10^{6} \mathrm{Btu} / \mathrm{hr} \text {; } \\
70 \text { bores at a useful average of } \\
2.5 \times 10^{6} \mathrm{Btu} / \mathrm{hr} \text {; and } 50 \text { bores at a } \\
\text { useful average of } 8 \times 10^{6} \mathrm{Btu} / \mathrm{hr}, \\
\text { respectively. }\end{array}$ & $\begin{array}{l}\text { Reynolds }(1970) \\
\text { Burrows }(1970) \\
\text { Burrows } \\
\text { (1974) }\end{array}$ \\
\hline \multirow[t]{2}{*}{ Japan $^{\dagger}$} & Towada & District heating & $14 \mathrm{~kg} / \mathrm{sec}$ at $70^{\circ} \mathrm{C}$ & $2.1^{\dagger+\dagger}$ & $\begin{array}{l}\text { System constructed in } 1963 \text { with } \\
11.5 \mathrm{~km} \text { transmission line from } \\
\text { Sarukuro springs. }\end{array}$ & $\begin{array}{l}\text { Mashiko and } \\
\text { Hirano (1970) }\end{array}$ \\
\hline & Okawa & District heating & $22 \mathrm{~kg} / \mathrm{sec}$ at $70^{\circ} \mathrm{C}$ & $3.2^{\dagger+\dagger}$ & $\begin{array}{l}\text { System provides heating for } 3,000 \\
\text { houses from a } 12 \mathrm{~km} \text { transmission } \\
\text { line. }\end{array}$ & $\begin{array}{l}\text { Mashiko and } \\
\text { Hirano (1970) }\end{array}$ \\
\hline . & Ukiyama & District heating & $12 \mathrm{~kg} / \mathrm{sec}$ at $40^{\circ} \mathrm{C}$ & $0.25^{\dagger+\dagger}$ & $\begin{array}{l}\text { Water is heated to } 55^{\circ} \mathrm{C} \text { in fossil } \\
\text { fueled boiler. }\end{array}$ & $\begin{array}{l}\text { Mashiko and } \\
\text { Hirano }(1970)\end{array}$ \\
\hline . & Aomor 1 & District heating & $22 \mathrm{~kg} / \mathrm{sec}$ at $60^{\circ} \mathrm{C}$ & $2.3^{++t}$ & $\begin{array}{l}\text { Provides heating for } 34 \text { hotels and } \\
140 \text { houses, with water from the } \\
\text { Asamushi hot spring area. }\end{array}$ & $\begin{array}{l}\text { Mashiko and } \\
\text { Hirano }(1970)\end{array}$ \\
\hline Hungary & Szeged & District heating & $\because \vdots: \quad:$ & & $\begin{array}{l}\text { University c1inics and } 1,200 \text { flats - } \\
226,000 \mathrm{~m}^{3}\end{array}$ & $\begin{array}{l}\text { Einarsson (1973) } \\
\text { Boldizar (1974) }\end{array}$ \\
\hline
\end{tabular}


Table 4. (cont)

\begin{tabular}{|c|c|c|c|c|c|c|}
\hline Country & Localities & $\begin{array}{l}\text { Description } \\
\text { of application }\end{array}$ & $\begin{array}{l}\text { Production, } \\
\text { steam flow rate or } \\
\text { water flow rate }\end{array}$ & $\begin{array}{l}\text { Associated } \\
\text { power } \\
\left(\mathrm{MW}^{*}\right)\end{array}$ & Comments & References \\
\hline \multirow[t]{2}{*}{ Hungary (cont) } & Hỏdmezövasàrhely & $\begin{array}{l}\text { Individual } \\
\text { space heating }\end{array}$ & & & Factory and hospital $-172,000 \mathrm{~m}^{3}$ & Einarsson (1973) \\
\hline & Mako & $\begin{array}{l}\text { Individual } \\
\text { space heating }\end{array}$ & & & Hospital $-80,000 \mathrm{~m}^{3}$ & Einarsson (1973) \\
\hline France & Melun & District heating & $28 \mathrm{~kg} / \mathrm{sec}$ at $70^{\circ} \mathrm{C}$ & $4.1^{t+t}$ & $\begin{array}{l}\text { Heating and hot water for } 3,000 \\
\text { housing units }\end{array}$ & Maugis (1969) \\
\hline
\end{tabular}

* This is an estimate of the rate at which energy is supplied to and available to be utilized by the application. If no other information is available, it is based on the wellbore flow rate.

The total quantity of water pumped from hot wells in Japan 18 reported to be $20,000 \mathrm{~kg} / \mathrm{sec}$ by Mashiko and Hirano (1970). Boldizar (1974) reports there are 131 geothermal wells in Hungary with a total output of $211 \mathrm{~kg} / \mathrm{sec}$. The total energy production at peak load 18 about $770 \mathrm{kN}$, much of which is devoted to agriculture at this time.

${ }^{t+\dagger}$ Where Power $=\left[\right.$ temperature of water ${ }^{\circ} \mathrm{C}$ - discharge temperature $\left.\left(35^{\circ} \mathrm{C}\right)\right][$ rate of $\mathrm{flow}(\mathrm{g} / \mathrm{sec})]\left[4.186 \times 10^{-6} \mathrm{Mw}-\mathrm{sec} / \mathrm{cal}\right]$. 


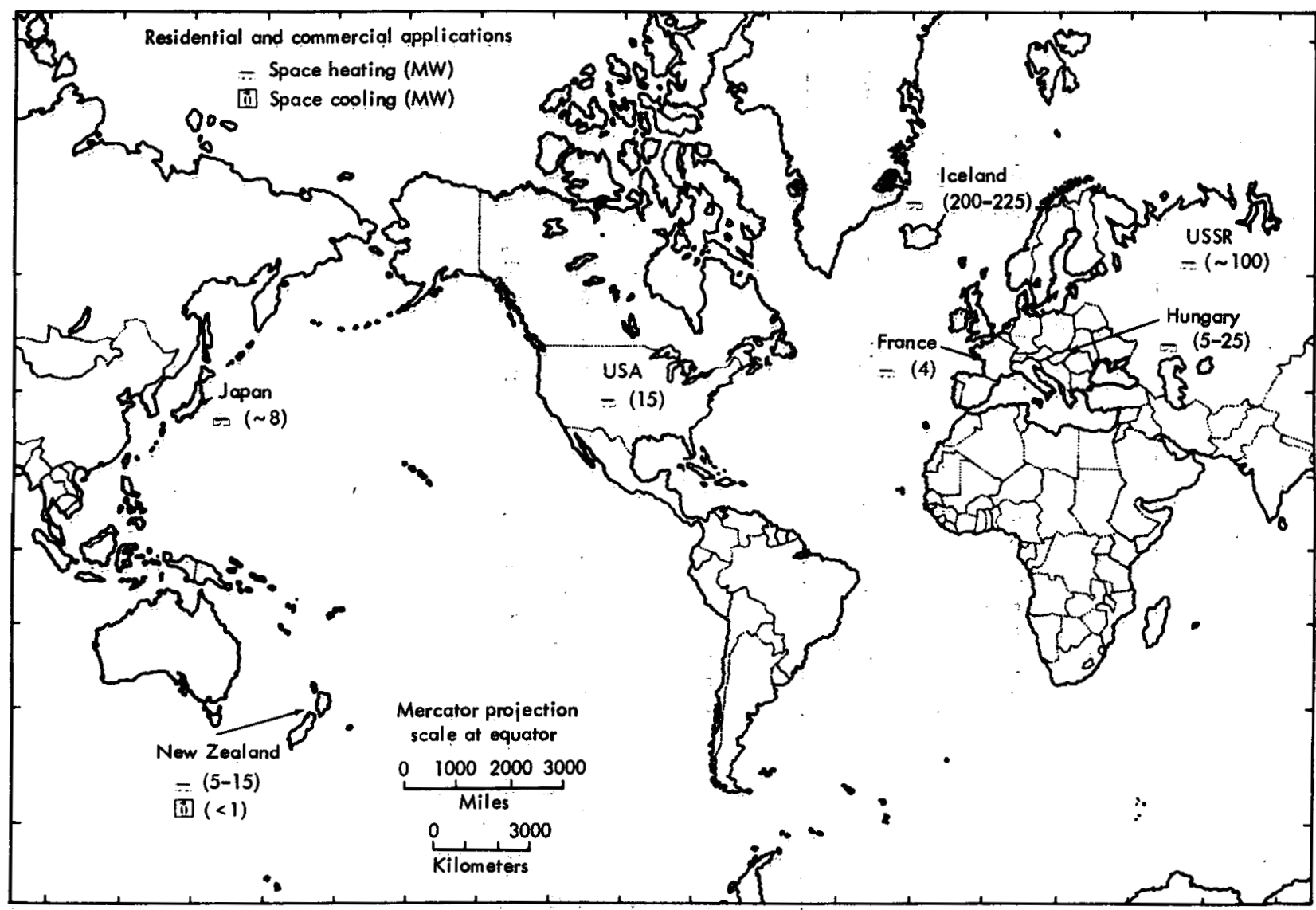

Fig. 9. Geothermal regions of the world, residential and commercial applications. Details of these applications can be found in Table 4. The leading user of geothermal resources for residential and commercial applications is Iceland, where almost all residences in the city of Reykjavik are heated geothermally.

have difficulty forming because they are not recognized as a public utility and have not had sufficient backing from government officials. District heating systems appear to nave the most promise for countries where the national government has or can have an extensive role in community planning.

\section{Survey of Existing Systems}

The present use of geothermal energy for residential and commercial applications is quite widespread and represents about $400 \mathrm{MW}$ average. energy consumption. Table 4 lists. the significant present applications. Figure 9 shows the distribution of these applications throughout the world.

The many applications represent a number of different types of systems. The systems can be classified as district heating or individual systems. Table 4 indicates that most of the significant applications are of 
the district-heating type, which is to be expected because district heating systems are the main way in which geothermal energy can economically supply large markets for space heating. The most significant district heating system is the wellknown system of Reykjavik, Iceland. This system accounts for well over half of the total geothermal power presently being used for space heating. The two significant applications which have individual systems are Rotorua, New Zealand and Klamath Falls, Oregon, U.S.A.

Several of the systems will be briefly described to illustrate the conceptual design of some presently operating large systems as well as some of the unique ways in which geothermal energy is being used for providing comfort. The discussion will not treat the details of the systems, which in most cases are available in the cited literature.

\section{Reykjavik System.}

The use and development of geothermal energy in Iceland has had numerous reportings: Bodvarsson (1954), Bodvarsson and Zoega (1961), Bodvarsson and Palmason (1961), Bodvarsson and Enarsson (1964), Sigurdsson (1961), Zoega and Kristinsson (1970), Palmason and Zoega (1970), Ragnars et al. (1970),
Einarsson (1973) and Zoega (1974). The following is taken mainly from Zoega (1974). The Reykjavik municipal district heating system which heats about 11,000 houses ( $99 \%$ of all houses in the city), and serves about 88,000 inhabitants obtains hot water from two geothermal areas. As of 1974, $3,600 \mathrm{~m}^{3} / \mathrm{hr}$ of $80^{\circ} \mathrm{C}$ water (170 i $\left.\mathrm{MW}\right)$ was available from the Reykir area located some $15 \mathrm{~km}$ east of the city and $1700 \mathrm{~m}^{3} / \mathrm{hr}$ of $119^{\circ} \mathrm{C}$ water (155 MW) was available from the Reykjavik area within the city. Work presently in progress will extend the system to another 26,000 inhabitants in three neighboring communities by 1976 . Figure 10 shows the system both before the end of 1974 and after the system extension that is to take place in 1975-76.

Figure 11 schematically shows the basic distribution system. The water is pumped out of the boreholes with deep-well pumps set at some $120-\mathrm{m}$ depth, through collecting pipelines to the area's main pumphouse. The - deepwell pumps lower the water level in tne borehole, thus increasing the inflow of water, and for waters at temperatures above $100^{\circ} \mathrm{C}$ provide sufficient pressure to avoid boiling in the systems. Waters at or above $100^{\circ} \mathrm{C}$, pass through a deaerator at the main pumphouse to remove gaseous nitrogen. The water is then pumped 


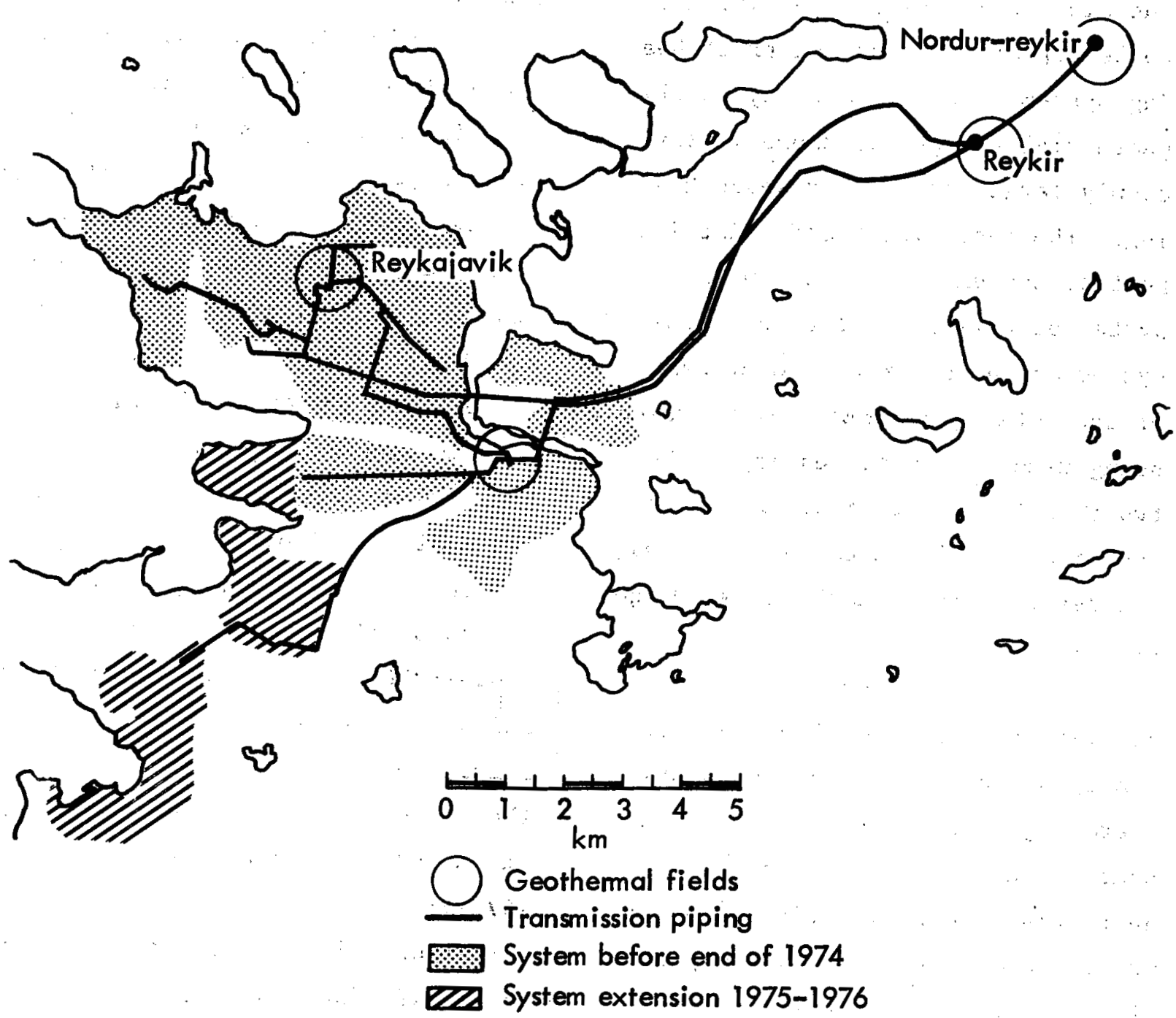

Fig. 10. Reykjavik municipal district heating areas and geothermal fields. Geothermal resources from within the city of Reykjavik and also from Reykir and Nordur-reykir service Reykjavik and will be extended to the southwest in 1975-76.' (Zoega, 1974)

through high-temperature mains to the various district stations in the city. Waters below $100^{\circ} \mathrm{C}$, are held in open clsterns at the main pumphouse before being pumped into distribution mains. Since the system uses two resources with quite different temperatures, two types of final distribution systems have developed. In the oldest part of the system, which was designed for the lower temperature waters of the Reykir area, a single-pipe design is used where the warm water is supplied to the house for heating and domestic use and then drained to the sewer. The availability of waters from the Reykjavik area at temperatures too high for safe direct use led to the two-pipe design whereby a sufficient quantity of cooled water from the houses is collected in return water 


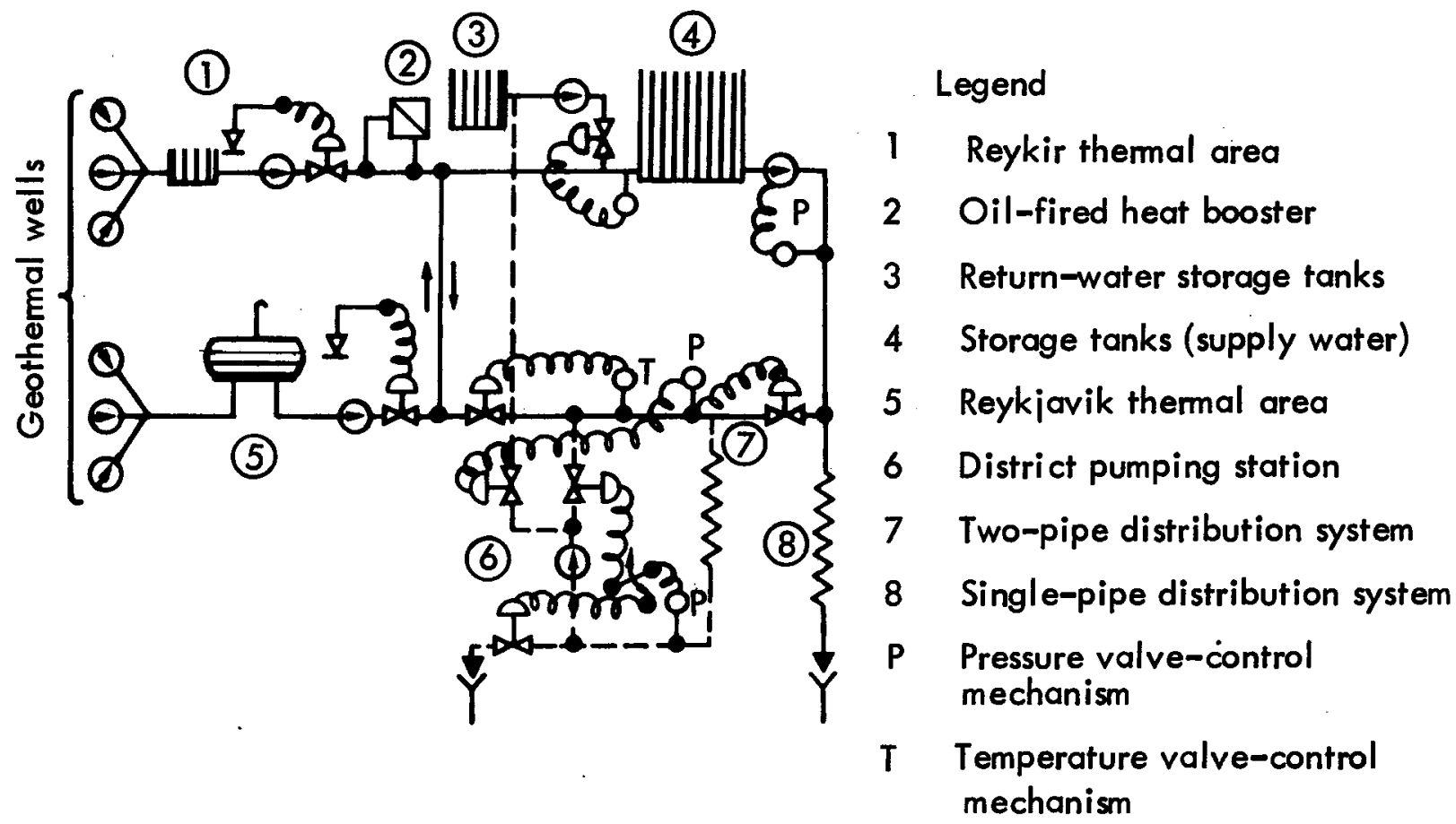

Fig. 11. Schematic diagram of Reykjavik geothermal heating system. Geothermal water from the high-temperature Reykjavik thermal area can be combined with cooler water, stored as appropriate, and finally used to service one- and two-pipe distribution systems. Cooler water from the Reykir thermal area is used directly in either one- or twopipe systems. An oil-fired heat booster can increase the temperature of the Reykir resource on cold days, as necessary. Cooled water from the two-pipe system can be returned to storage for combination with water from the Reykjavik thermal area that is too hot to use directly. (Zoega, 1974)

storage tanks for subsequent mixing with the high-temperature water in order to achieve the desired distribution temperature for heating and domestic use. A number of substations throughout the city are fed with hightemperature water and serve combinations of single- and two-pipe systems (illustrated as 6,7 ; and 8 of Fig. 11).

Standard house connections for a two-pipe system are shown in Fig. 12. The supply solenoid valve (6) is controlled by a room thermostat, and a high-temperature limit switch controls the solenoid valve (6) in the return line from the radiators. - Demand is limited by a sealed regulating valve, and consumption is measured with an integrating water meter. The piping is all-welded black steel pipe laid underground. Piping of $3^{\prime \prime}$ diameter or larger are laid in concrete channels and insulated with rock wool insulation as shown in Fig. 13. Smaller pipe is insulated 


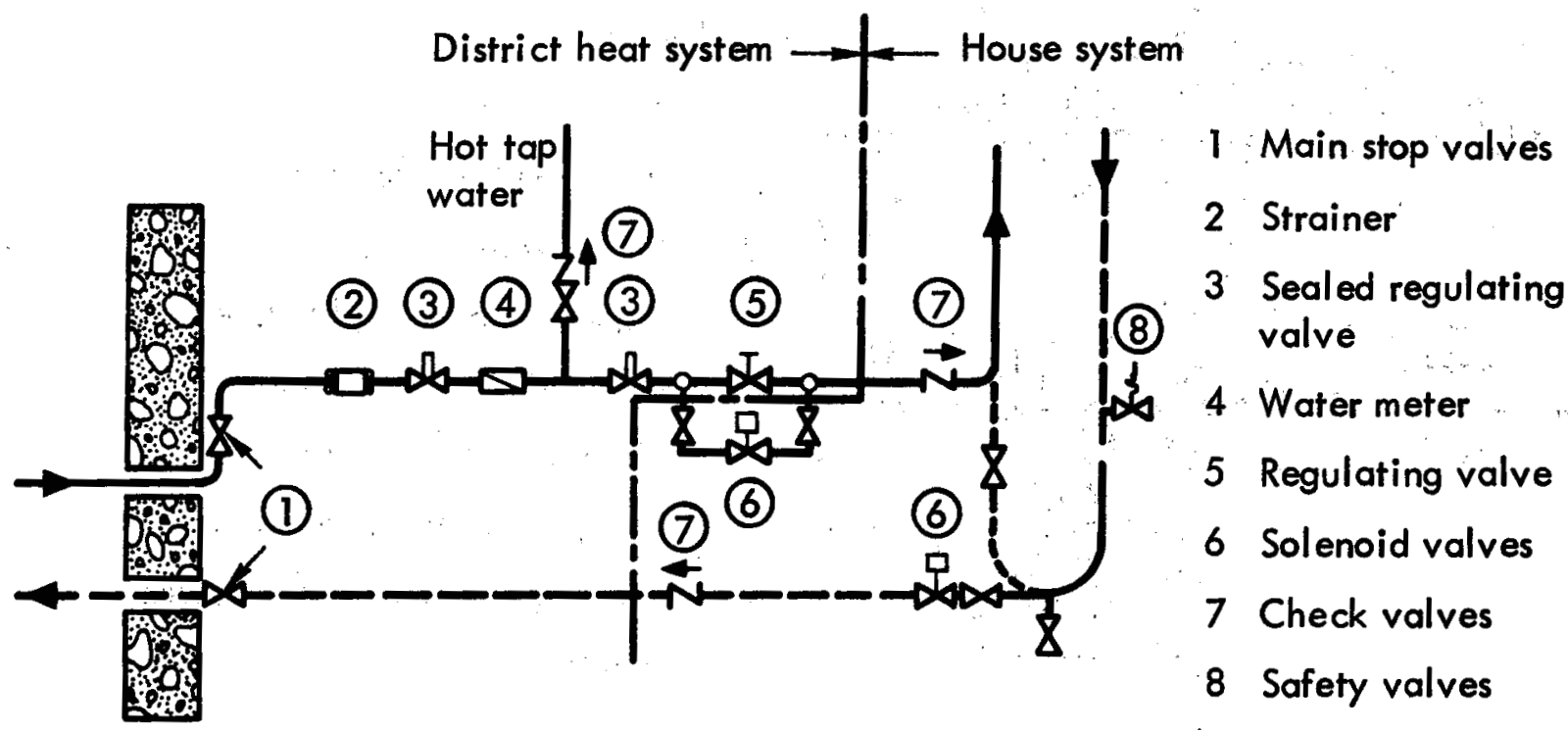

Fig. 12. House connection for two-pipe Reykjavik system. A thermostat controls the supply of hot water to and from radiators in order to achieve the desired room temperature. (Zoega, 1974).

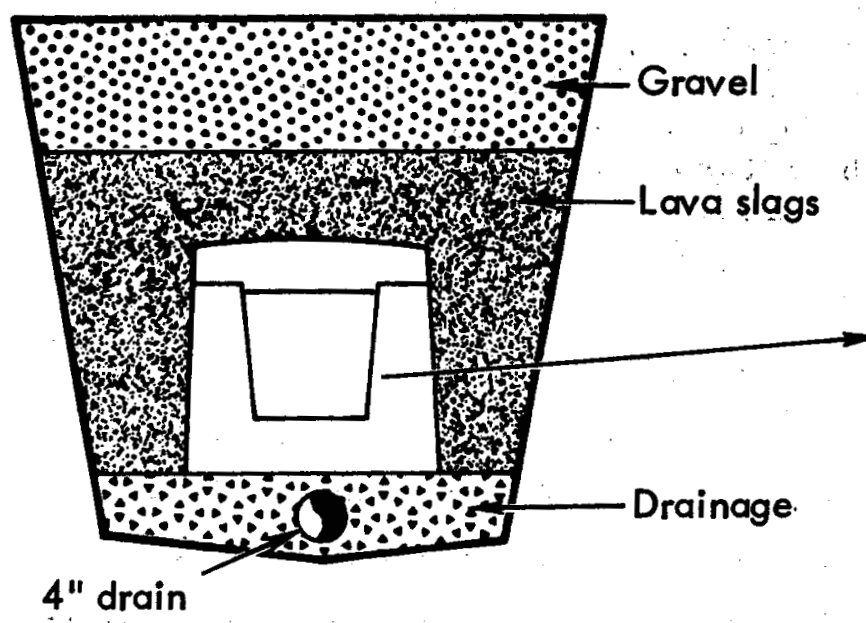

Buried channel

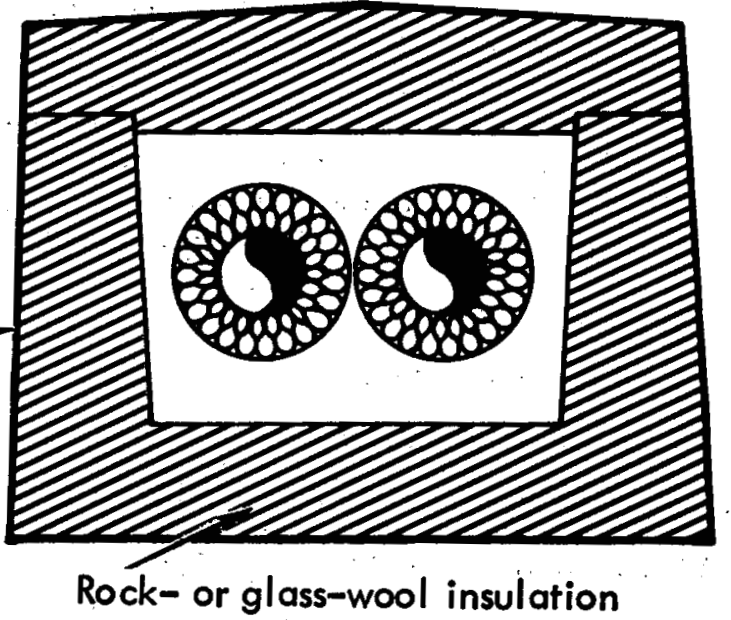

Street-main channels

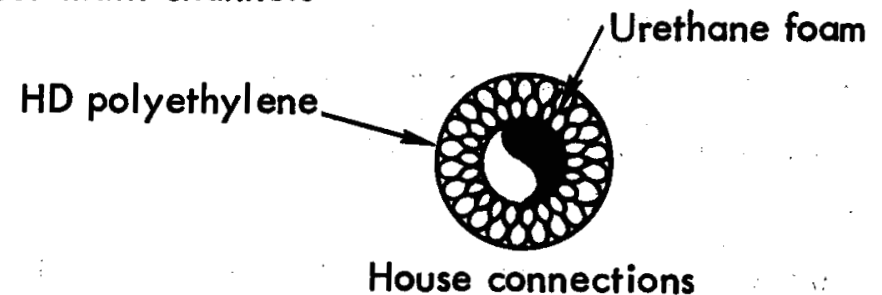

Fig. 13. Piping arrangement and insulation for Reykjavik systems, street main channels and house connections. Rock wool and/or glass wool and urethane foam are used as insulation. (Zoega, 1974). 
with polyurethane foam and has an outside protective coating of highdensity polyethylene pipe (Fig. 13). The peak heating requirements of this system are met by increasing the temperature of the supply water in an oil-fired boiler plant.

\section{District Heating Systems in the U.S.S.R.}

District heating from geothermal waters has received a substantial amount of attention in the U.S.S.R. See Kremnjov et al. (1970), Lokchine et al. (1970), Sukharov et al. (1970) and Tikhonov et al. (1970). A number of well thought out systems with unique aspects, all using waters in the 50 to $90^{\circ} \mathrm{C}$ range, have been reported. Apparently, the mineralization of the water is of ten too extensive to permit direct use in radiators and for tap water, so heat exchangers are widely applied. Items of special interest are:

a. The waste-water temperature is designed to be quite low through the use of two-stage heat exchangers for tap water and for heating of air.

b. Although peaking requirements are routinely met with fossil fueled bollers or electricity, at least one application (at Paratounka, Kamchatka) uses a heat pump for meeting peak requirements. During peak requirements, the return water leaving the building is split into two streams. One stream is cooled in the evaporator of the heat pump and then discharged while the other stream is heated in the condenser of the heat pump and is rerouted to the water supply pipe to provide additional heating capacity.

c. Frequently, industrial and/or agricultural (hot houses, soil warming, etc.) uses are combined with the district heating systems. Such efforts can significantly improve the annual load factor particularly if the additional requirement falls outside the period of maximum demand, which is usually the case for soil warming schemes.

Geothermal Heating in Hungary. In the early 1960's, there was considerable interest in using geothermal energy for residential and commercial heating in Hungary. However, the drilling for geothermal fluids led to the discovery of a very large oil and gas filed which greatly decreased the need for geothermal energy use for this purpose. Since that time, the emphasis on utilization 


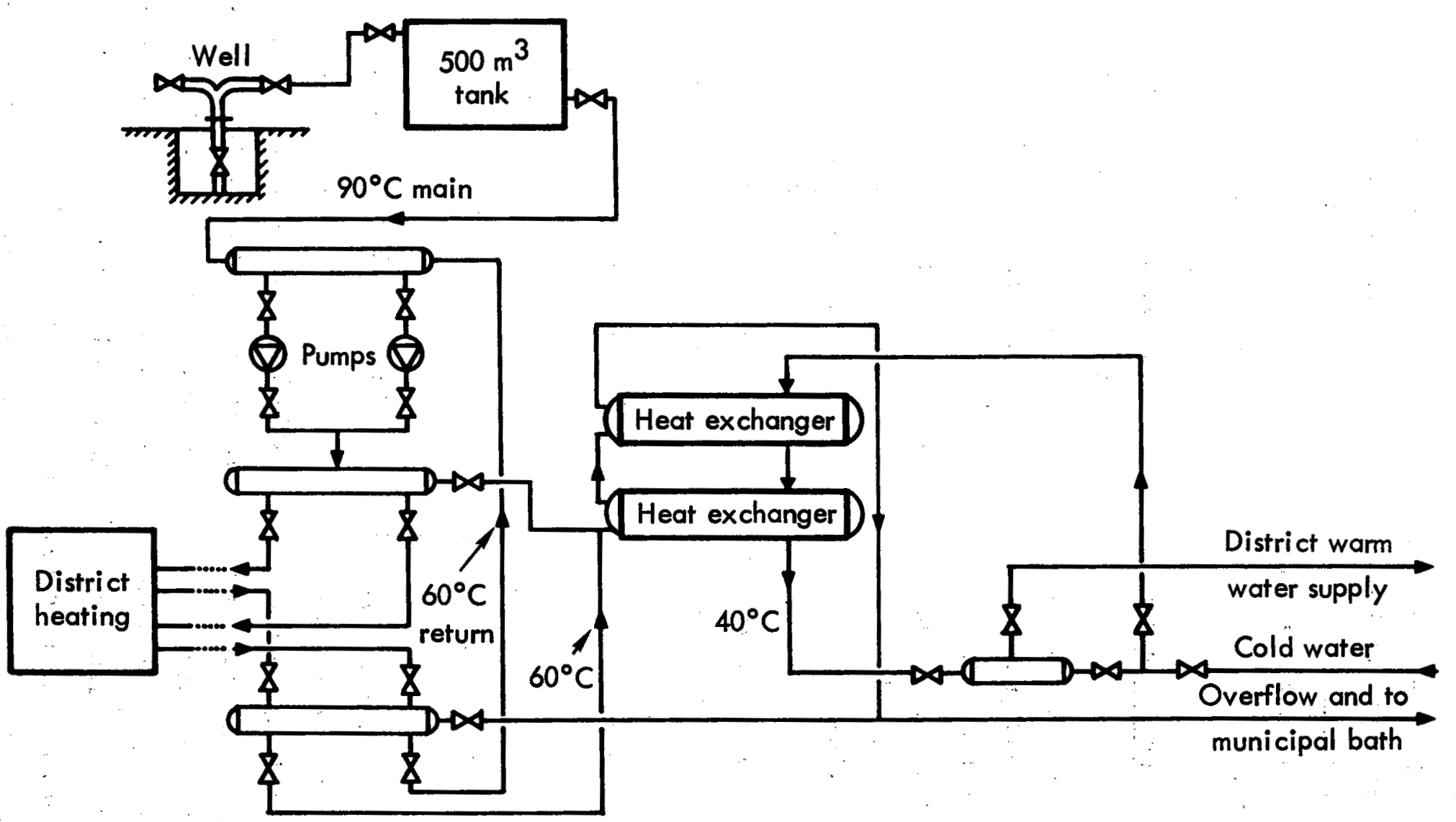

Fig. 14. First district heating system in Hungary. District heating, domestic warm water, and municipal bath needs are satisfied by this system. (Boldizsar, 1974). 
of geothermal energy in Hungary has been on agricultural applications, but several space heating projects have developed. Figure 14 shows the first district heating system in Hungary, which supplies a district of 1800 flats, several municipal buildings, school shops, and kindergartens. Not shown is a gas-fired boiler which carries the peak load (Boldizar, 1974 and 1970).

Individual Space Heating in Klamath Falls, Oregon, U.S.A.

Since about 1930, the predominant method of utilizing geothermal energy for space heating and domestic hot water heating in Klamath Falls has been a downhole heat exchange system. Figure 15 (Lund et al., 1974) shows the various types of systems that are presently in use. The systems depicted in A, B, and C of Fig. 15 are the most common. Circulation can usually be accomplished by thermosyphon although small circulation pumps are now almost standard. Some of the older systems discharge the water to the sewer after using it; but recent city ordinances have limited this practice, and the favored system is the downhole exchanger systems which have no water discharge. Most of the downhole heat exchangers are merely standard black iron pipe of sufficient length. These systems typically have minimal corrosion problems, the most common failure occurring after an average of 14 years and due to corrosion of the heatexchange pipe at the air-water interface.

Presently, the various systems serve about 500 locations with 400 wells at a yearly average heating rate of $5.6 \mathrm{MW}$. Because the well drilling costs are a large part of the costs of such systems, it is usual, and now almost necessary, for several homeowners to share a well.

Space Cooling in Rotorua, New Zealand.

There has been significant activity in the use of geothermal energy for heating around Rotorua, New Zealand (Kerr et al., 1961; Cooke, 1970; Reynolds, 1970; and Burrows, 1970 and 1974). The system of the Rotorua International Hotel is unique in that it is the only system designed for both comfort heating and cooling using geothermal resources. The system is schematically shown in Fig. 16. The system uses geothermal water at about $150^{\circ} \mathrm{C}$ and 6 atmospheres, gage (atg) in a heat exchanger to heat fresh water in a piping circuit to about $120^{\circ} \mathrm{C}$. The $120^{\circ} \mathrm{C}$ water is used in radiators, tap water heaters, and to drive the absorption unit. The peak heating requirements of each of the uses are (1) space heating $0.58 \mathrm{MW},(2)$ domestic water heating - 
Legend

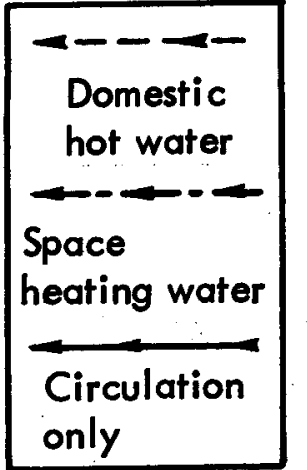

(a) 2-inch heat loop, no domestic use

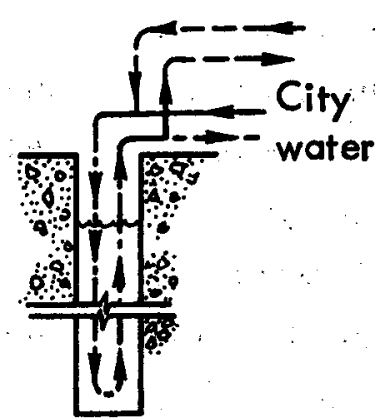

(b) 2-inch heat loop, 3/4" domestic line; turned off heat loop

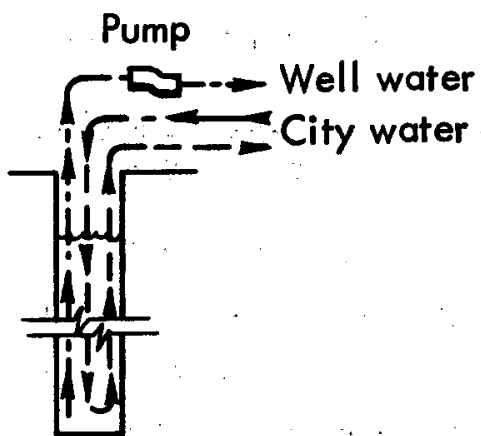

(d) 3/4" domestic loop; direct use (pumped) of well water for heating and then discharged

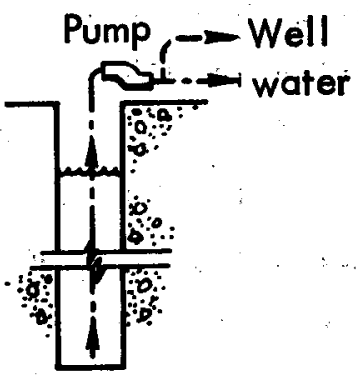

(f) Direct use of well water for heating and domestic use (optional)

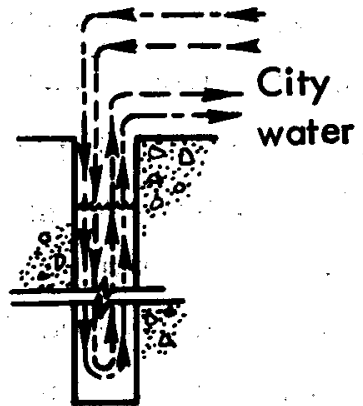

(c) 2-inch heat loop; 3/4" domestic loop

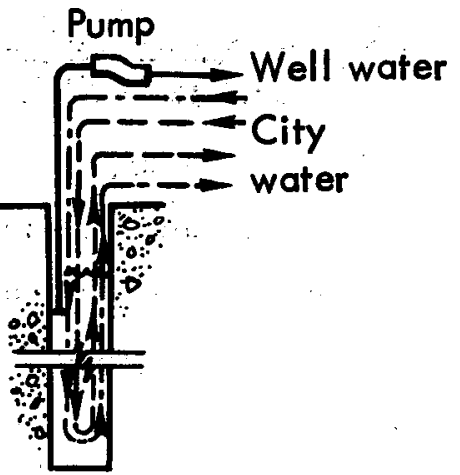

(e) 2- each heat loop 3/4" domestic loop; well water pumped to discharge line to increase temperature

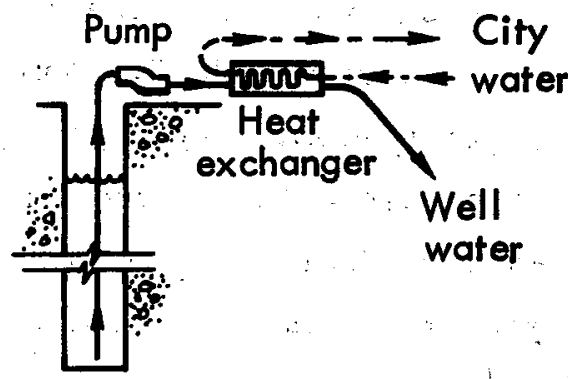

(g) Well water pumped through heat exchanger to waste or reinjection; city water used for heating and domestic use (optional)

Fig. 15. jown-hole heat exchanger systems in use in Klamath Falls, Oregon, USA. (Lund et a1., 1974). 


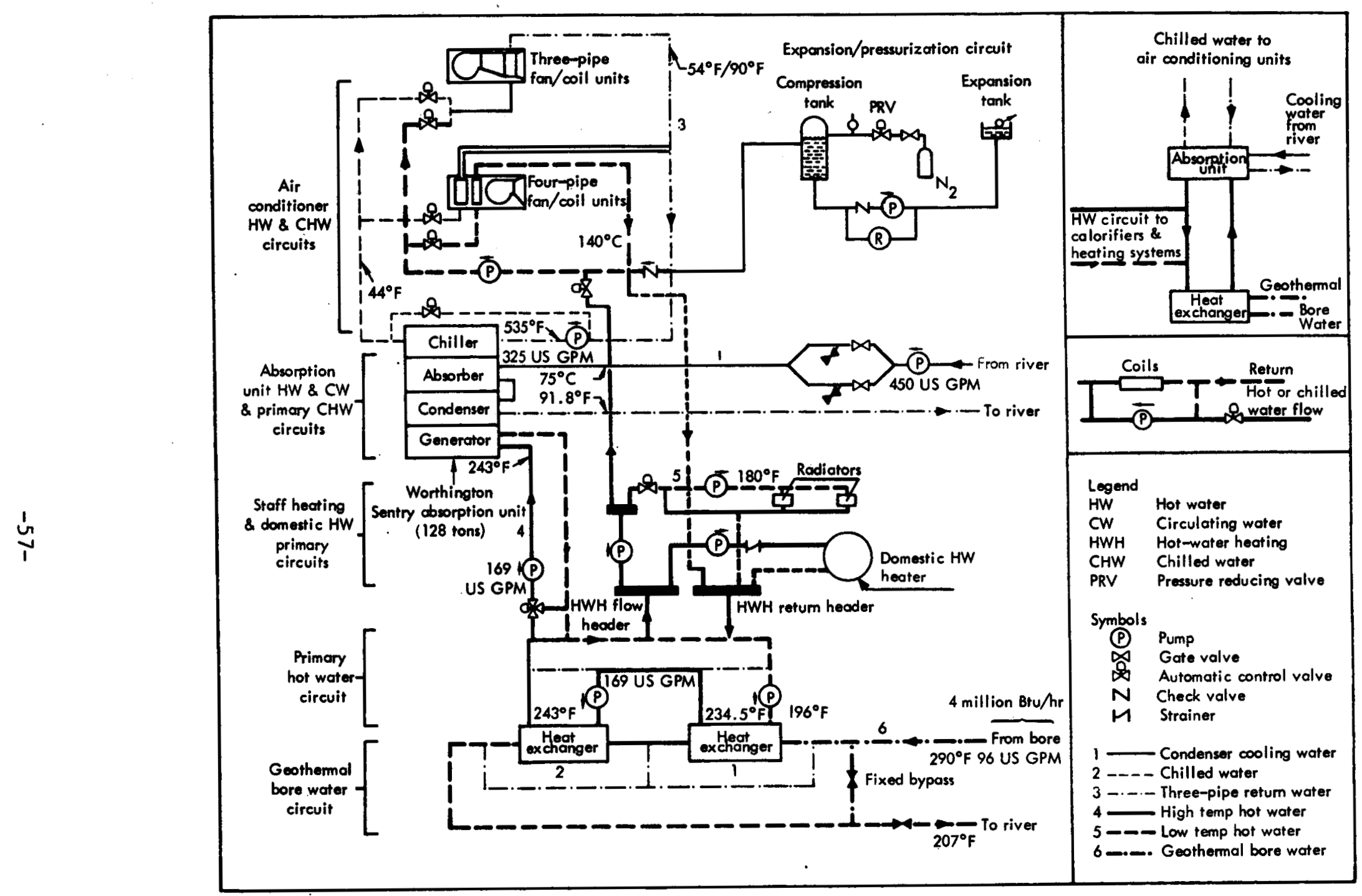

Fig. 16. Geothermal heating and air conditioning installation in the Rotorua International Hotel, New Zealand. The system uses geothermal water at about $150^{\circ} \mathrm{C}\left(290^{\circ} \mathrm{F}\right.$ ) and 6 atmospheres (guage) in a heat exchanger to heat fresh water. The hot fresh water is used in radiators, tap water heaters, and to drive an absorption refrigeration unit. (Reynolds, 1970). 
$0.58 \mathrm{MW}$, and (3) heating for the absorption unit $-0.67 \mathrm{MW}$.

\section{Future Trends}

The future for geothermal district heating appears good because of the apparently great number of resources with capability for meeting heating at the temperatures required and because of the continuing increase in alternative fuel prices. We feel that in many countries where the governmental structure permits the development of systems to serve large districts, geothermal-powered systems will prove to be very economical in comparison with those fueled from fossil fuels.

When the geothermal-resource temperatures permit it, industrial complexes can be integrated with district heating systems to improve the load factor as well as to take advantage of economies of scale. The possibilities here have not been significantly investigated, although some countries (notably the U.S.S.R. and Iceland) practice this to a limited extent. Applications in this area are expected to increase substantially in the future.

District heating is an efficient use of geothermal waters that exist at temperatures in the range of $40^{\circ} \mathrm{C}$ to $150^{\circ} \mathrm{C}$, allowing greater than $50 \%$ utilization of the available enthalpy. This type of use appears to represent the best long term use of lowtemperature resources, particularly when one considers that electricity generation at these temperatures would result in an overall efficiency of less than $7 \%$.

$$
\text { Perhaps the most interesting }
$$
future development will be in the field of utilizing totally stimulated dry-hot-rock resources to produce geothermal waters for space heating. Bodvarsson (1974) has investigated the possibility of total resource stimulation for space heating in regions in Iceland where natural geothermal resource systems are absent or have insufficient potential.

\section{AGRICULTURAL APPLICATIONS}

OF GEOTHERMAL ENERGY

\section{Introduction}

The use of warm waters to establish and maintain optimal temperature conditions for plant and animal cultivation has received increased attention from the scientific community in the last decade. This interest is due in part to increasing world-wide protein needs and most recently to the increased demand and cost for fossil fuels (see Appendix F). Intensive cultivation to produce foodstuffs at the most rapid and most efficient rate within a limited controlled area requires concentrated heat energy. Moreover, this energy 
must be concentrated in the most essential vehicle of the biologic process - water. The direct concentration of heat in water is not a very efficient process and requires increasingly costly fuels. Moreover, the growing processes themselves absorb only a small fraction of this heat, and most is discharged as waste.

The concept of utilizing waste heat, i.e. the warm water discharge from fossil fuel and nuclear electrical generating stations, has generated investigations of agricultural application for such low temperature waste heat. It is with the expectation of using these low-energy discharge waters that integrated greenhouse, agriculture and animal husbandry farm systems have been designed (Yarosh, et al., 1972). It is with the hope of using such waters that investigation of optimal plant and animal growth-temperature and other environmental parameters have been undertaken.

It is the purpose of this section, however, to discuss the agricultural application of geothermal waters. Such agricultural uses have the potential to produce vast quantities of food at great efficiency and reduced cost.

There are three primary agricultural applications of geothermal fluids. The world-wide distribution and extent of these three uses, $1 . e$. (1) greenhouses, (2) animal husbandry and (3) aquaculture, are summarized in Fig. 17. Table 5 provides a description of existing geothermal agricultural applications. The geothermal power associated with these applications is on the order of 5000 to $5500 \mathrm{MW}$.

Greenhouse Applications of Geothermal Waters

The most extensive agricultural use of geothermal waters is in greenhouses. This application is more common in higher latitudes where growing seasons are short and greenhouse agriculture is necessary to meet the local demand for vegetables.

The most intense use has been in Iceland, where the short growing season and low level of sunshine requires greenhouse agriculture. Iceland is located in a most favorable geologic position from the point of view of availability of geothermal resources. It is part of the midAtlantic-Rift System, and abounds with geothermal springs. Here the use of geothermal waters to heat greenhouses was logical and has proved successful. Most of their tomato, lettuce, cucumber and other vegetable needs are met by geothermally heated greenhouse agriculture. 


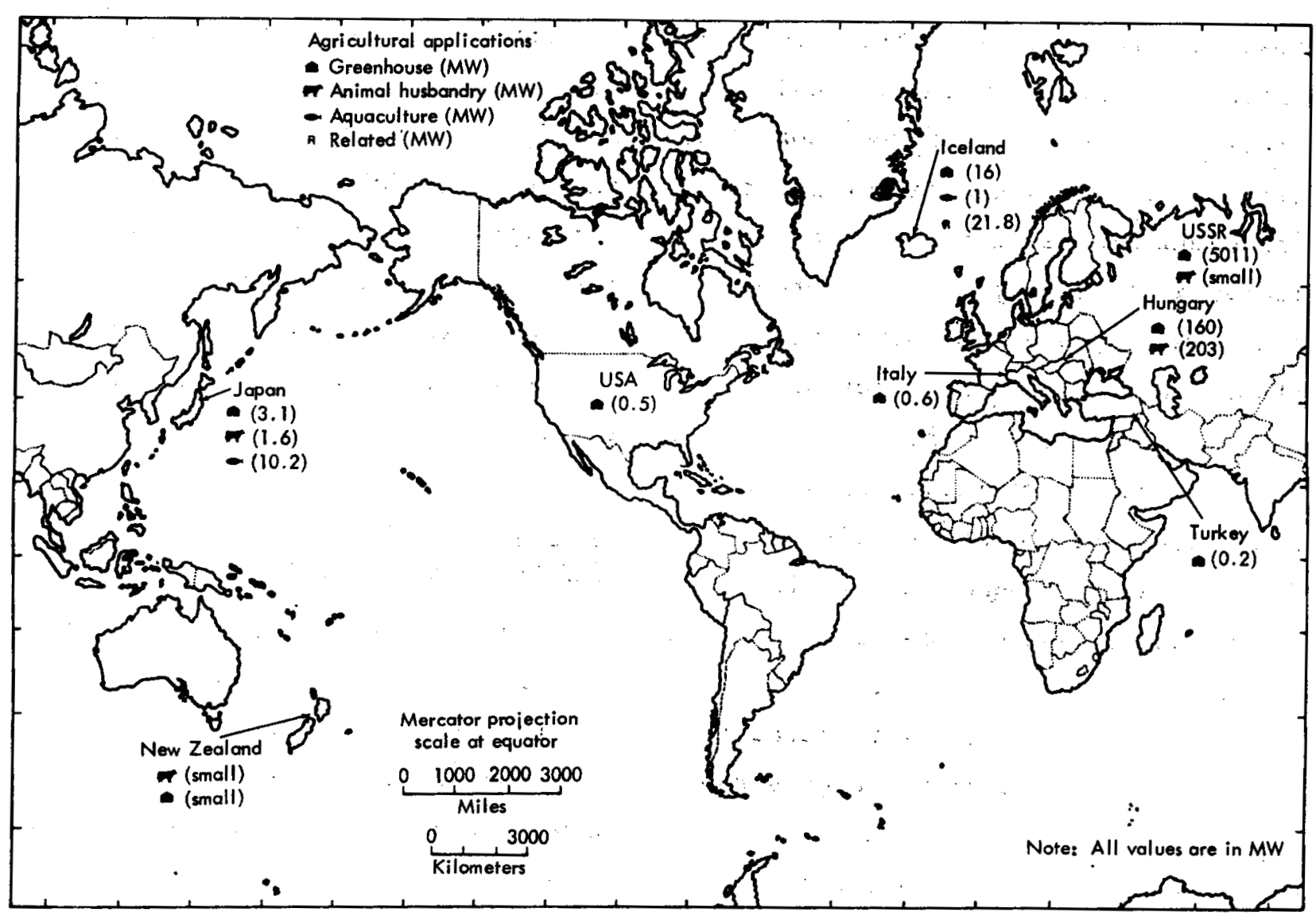

Fig. 17. Agricultural applications in various geothermal regions. Details of these applications can be found in Table 5. The leading user of geothermal resources for agricultural purposes is the Soviet Union, where over $5000 \mathrm{iW}$ are used in greenhouse operations.

The U.S.S.R. and Hungary have developed the most extensive geothermally heated greenhouses for vegetable and horticulture (Tikhonov, 1970). In Italy, New Zealand and the United States, the milder climates, extended growing season, the accessibility of low-cost fossil fuels, (at least in the past!), and the low level of current exploitation of geothermal resources have limited the application of geothermal resources for greenhouse agriculture.
A critical factor affecting the application of geothermal waters to greenhouse heating is the purity of the water required for direct soil heating operations. Most geothermally heated greenhouses use geothermal waters directly either on the soil alone or mixed with cool potable or irrigation water. Therefore, acceptably pure geothermal water is required even if some mixing takes place. The increasing development and application of heat exchangers will allow the use 
Table 5. Agricultural applications of geothermal energy

\begin{tabular}{|c|c|c|c|c|c|c|c|}
\hline Application & Country & Localfties & $\begin{array}{l}\text { Description of } \\
\text { application }\end{array}$ & Power output & $\begin{array}{l}\text { Assoc. power } \\
\text { intitiated (MW) }\end{array}$ & Comments & Reference \\
\hline \multirow[t]{9}{*}{ Greenhouses } & Iceland & $\begin{array}{l}\text { Various } \\
\text { localities }\end{array}$ & . & $120 \mathrm{~T} \mathrm{cal} /$ year & ${ }^{\star} 15.9$ & $\begin{array}{l}\text { Glass greenhouses heated by } \\
\text { natural steam and/or hot } \\
\text { water. Heat use elther direct } \\
\text { or heat exchangers. }\end{array}$ & $\begin{array}{l}\text { Palmason, G. } \\
\text { and Zoega, J. } \\
(1970)\end{array}$ \\
\hline & & & & & & $\begin{array}{l}1 / 3 \text { Flowers } \\
2 / 3 \text { Vegetables - tomatoes, } \\
\text { cucumbers, lettuce } \\
\text { Cost }-\$ 3.80 / \mathrm{G} \mathrm{Cal.} \mathrm{(1970)}\end{array}$ & $\begin{array}{l}\text { Dragone, G. } \\
\text { and Rumi, } 0 . \\
(1970)\end{array}$ \\
\hline & USSR & $\begin{array}{l}\text { Makhach-Kala } \\
\text { and other } \\
\text { localities }\end{array}$ & & $\begin{array}{l}25,000,000 \mathrm{~m}^{2} \\
56,000 \mathrm{~m}^{2} \text { of } \\
\text { greenhouse }\end{array}$ & $t_{5011.2}$ & $\begin{array}{l}1,002,240 \text { tons of tomatoes, } \\
\text { cucumbers and other } \\
\text { vegetables per year. }\end{array}$ & $\begin{array}{l}\text { Tikhonov, A. N. } \\
\text { and Dvorov, } \\
\text { I. M. (1970) }\end{array}$ \\
\hline & Italy & Castelnuovo & & $\begin{array}{l}3,000 \mathrm{~m}^{2} \text { of } \\
\text { greenhouse }\end{array}$ & +0.6 & & Barbler (1975) \\
\hline & & $\begin{array}{l}\text { Galzignano } \\
\text { (Padua) }\end{array}$ & & $\begin{array}{l}20,000 \mathrm{~m}^{2} \text { of } \\
\text { greenhouse }\end{array}$ & $t_{4.0}$ & & \\
\hline & Hungary & $\begin{array}{l}\text { Szentes and } \\
\text { various other } \\
\text { localities }\end{array}$ & & $\begin{array}{l}800,000 \mathrm{~m}^{2} \text { of } \\
\text { greenhouse }\end{array}$ & ${ }^{+} 160$ & $\begin{array}{l}\text { Typical greenhouse vegetables } \\
\text { plus paprika. Typical } \\
\text { horticulture. }\end{array}$ & $\begin{array}{l}\text { Boldizsar, } T \text {. } \\
(1970)\end{array}$ \\
\hline & & - & & & & & $\begin{array}{l}\text { Belteky, L. } \\
(1972)\end{array}$ \\
\hline & Japan & $\begin{array}{l}\text { Vartous } \\
\text { localities }\end{array}$ & & $\begin{array}{l}15,528 \mathrm{~m}^{2} \text { of } \\
\text { greenhouse }\end{array}$ & $t_{3.1}$ & $\begin{array}{l}\text { Horticulture - varlous } \\
\text { species. Vegetables - } \\
\text { tomatoes, cucumbers, papayas, } \\
\text { melons, ganana, eggplant. } \\
3 \text { types of graenhouse: glass, } \\
\text { plastic, vinyl. }\end{array}$ & $\begin{array}{l}\text { Komagata, s. } \\
\text { et al., } \\
(1970)\end{array}$ \\
\hline & USA & Oregon & & $\begin{array}{l}26,000 \mathrm{ft}^{2} \text { of } \\
\text { greenhouse }\end{array}$ & ${ }^{\dagger} 0.48$ & $\begin{array}{l}\text { Steel framed ftherglass } \\
\text { greenhouse. } 70^{\circ} \mathrm{F} \text { year round - } \\
\text { automatic environmental con- } \\
\text { trol system. Heat exchanger. } \\
\text { Tomatoes. }\end{array}$ & $\begin{array}{l}\text { Head, J., } \\
(1970)\end{array}$ \\
\hline
\end{tabular}


Table 5. (cont)

\begin{tabular}{|c|c|c|c|c|c|c|c|}
\hline Application & Country & Localities & $\begin{array}{l}\text { Description of } \\
\text { application }\end{array}$ & Power output & $\begin{array}{l}\text { Assoc. power } \\
\text { initiated (MW) }\end{array}$ & Comments & Reference \\
\hline \multirow[t]{2}{*}{$\begin{array}{l}\text { Greenhouses } \\
\text { (cont) }\end{array}$} & New Zealand & $\begin{array}{l}\text { Various } \\
\text { localities }\end{array}$ & & Not mentioned & & $\begin{array}{l}\text { Mushrooms-soil is sterilized } \\
\text { and heated by using geothermal } \\
\text { fluids directly. Tree nursery- } \\
\text { seedlings. Tomatoes. }\end{array}$ & $\begin{array}{l}\text { Cooke, W. L. } \\
(1970) \\
i \because \\
\text { Burrows, W. } \\
(1970)\end{array}$ \\
\hline & Turkey & Kizildere & & $\begin{array}{l}8.8 \times 10^{11} \mathrm{cal} \\
\text { per } 6 \text { months }\end{array}$ & ${ }^{\star} 0.2$ & $\begin{array}{l}\text { Hot water passes through } \\
\text { radiator. Air forced through } \\
\text { radiator heats greenhouse. }\end{array}$ & $\begin{array}{l}\text { See } \\
\text { Appendix E }\end{array}$ \\
\hline \multirow[t]{5}{*}{$\begin{array}{l}\text { Anima1 } \\
\text { Husbandry }\end{array}$} & USSR & $\begin{array}{c}\text { Lorinsk } \\
\qquad \\
\cdots\end{array}$ & Fow1 runs & $\begin{array}{l}\text { Small } \\
\qquad, \\
\cdots\end{array}$ & Sma11 & $\begin{array}{l}\text { Part of the Chukotsk } \\
\text { collective farm }\end{array}$ & $\begin{array}{l}\text { Tikhonov, } \\
\text { A. N. and } \\
\text { Dvorov, I. } \\
(1970) \text {. }\end{array}$ \\
\hline & & $\begin{array}{l}\text { Various } \\
\text { localities }\end{array}$ & $\begin{array}{l}\text { Needs of cattle } \\
\text { breeding }\end{array}$ & $\begin{array}{l}\text { Smal1 } \\
\therefore \quad 1+\infty\end{array}$ & Sma11 & & \\
\hline & Hungary & $\begin{array}{l}\text { Various } \\
\text { localities }\end{array}$ & $\begin{array}{l}\text { Heating and } \\
\text { cleaning animal } \\
\text { shelters }\end{array}$ & $\begin{array}{l}25 \text { wells at } \\
7 \times 10^{6} \mathrm{xcal} / \mathrm{hr}\end{array}$ & ${ }^{*} 203$ & $\begin{array}{l}\text { Heating and cleaning milk } \\
\text { rooms, cattléstalls, pigsties, } \\
\text { chicken houses }\end{array}$ & $\begin{array}{l}\text { Boldizsar, T. } \\
(1970)\end{array}$ \\
\hline & Japan & $\begin{array}{l}\text { Minami-Izu } \\
\text { Shizuoka }\end{array}$ & $\begin{array}{l}\text { Heating poultry } \\
\text { houses, drying } \\
\text { droppings }\end{array}$ & $\begin{array}{l}115^{\circ} \mathrm{C} \text { water at } \\
300 \mathrm{l} / \mathrm{min}\end{array}$ & $t_{1.6}$. & $\begin{array}{l}\text { Yoshisawa poultry yard - } \\
\text { heating below floor with pipes. } \\
8000 \text { chickens - drying } \\
\text { droppings }\end{array}$ & $\begin{array}{l}\text { Komagata, S. } \\
\text { et al. (1970) } \\
\therefore\end{array}$ \\
\hline & & $\begin{array}{l}\text { Ueda, Beppu, } \\
\text { Oita. }\end{array}$ & Do & Small & & $\begin{array}{l}\text { Nakamura poultry yard - Do. } \\
\text { l600, chickens }\end{array}$ & \\
\hline \multirow{5}{*}{$\begin{array}{l}\cdots \\
\cdots \\
\cdots\end{array}$} & . & $\begin{array}{l}\text { Minami-Izu } \\
\text { Shizuoka }\end{array}$ & $\begin{array}{l}\text { Alligator croco- } \\
\text { dile breed ing }\end{array}$ & $\begin{array}{l}105^{\circ} \mathrm{C} \text { water at } \\
2000 \mathrm{\ell} / \mathrm{min}\end{array}$ & $+\dagger 9.7$ & $\begin{array}{l}\text { Alligators and crocodiles }- \\
20 \text { species. Geothermal water } \\
\text { mixed with cold to attain }\end{array}$ & $\therefore$ \\
\hline & & & & $\because$ & & $28^{\circ}-32^{\circ} \mathrm{C}$ & \\
\hline & New Zealand & Taupo & $\begin{array}{l}\text { Pig farm-heating- } \\
\text { sterilizing }\end{array}$ & $\begin{array}{l}\text { Unknown but } \\
\text { small }\end{array}$ & & $\begin{array}{l}\text { Geothermal steam: cook and } \\
\text { sterilize garbage feed; warm } \\
\text { piggery floors at } 85^{\circ} \mathrm{F} \text {; hose }\end{array}$ & $\begin{array}{l}\text { Kerr, R. N. } \\
\text { et al. (1961) }\end{array}$ \\
\hline & & & $\begin{array}{l}\text { Dry sheep } \\
\text { crutchings }\end{array}$ & $\begin{array}{l}\text { Unknown but } \\
\text { sma11 }\end{array}$ & & $\begin{array}{l}\text { pens; ; sterilize and concentrate } \\
\text { waste manure; drying of sheep } \\
\text { crutchings; boiling of sheep }\end{array}$ & \\
\hline & & & Dry wool cuttings & $\begin{array}{l}\text { Unknown but } \\
\text { smal1 }\end{array}$ & & cuttings & \\
\hline
\end{tabular}


Tab1e 5. (cont)

\begin{tabular}{|c|c|c|c|c|c|c|c|}
\hline Application & Country & Localities & $\begin{array}{l}\text { Description of } \\
\text { application }\end{array}$ & Power output & $\begin{array}{l}\text { Assoc. power } \\
\text { initiated (MW) }\end{array}$ & Comments & Reference \\
\hline \multirow[t]{3}{*}{ Aquacul ture } & Japan & $\begin{array}{l}\text { Hokkaido and } \\
\text { Kogashima } \\
\text { prefectures }\end{array}$ & Eel breeding & $\begin{array}{l}\text { Unknown but } \\
\text { sma11 }\end{array}$ & & $\begin{array}{l}\text { Utilizing water from hot } \\
\text { springs }\end{array}$ & $\begin{array}{l}\text { Komagata, S., } \\
\text { et al. (1970) }\end{array}$ \\
\hline & & $\begin{array}{l}\text { Shikabe, } \\
\text { Hokkaido }\end{array}$ & $\begin{array}{l}\text { Experimental } \\
\text { breeding station }\end{array}$ & $70 \mathrm{l} / \mathrm{sec}$ at $70^{\circ} \mathrm{C}$ & ${ }^{t+} 10.2$ & $\begin{array}{l}\text { Hot water Hokkaido hatching } \\
\text { center. Eels and Carp. }\end{array}$ & \\
\hline & Iceland & $\begin{array}{l}\text { Various } \\
\text { localities }\end{array}$ & $\begin{array}{l}\text { Experimental } \\
\text { salmon breeding } \\
\text { station }\end{array}$ & $7 \mathrm{\ell} / \mathrm{sec}$ at $70^{\circ} \mathrm{C}$ & ${ }^{++} 1$ & $\begin{array}{l}\text { Kollafjord experimental fish } \\
\text { farm. Rearing young salmon } \\
\text { to the smolt stage }\end{array}$ & $\begin{array}{l}\text { Matthiasson, M. } \\
(1970)\end{array}$ \\
\hline \multirow[t]{2}{*}{ Related } & Japan & $\begin{array}{l}\text { Kannawa, } \\
\text { Bappu, Oita }\end{array}$ & Drying rice & Unknown & & $\begin{array}{l}\text { Datly rice processing } \\
\text { capacity }=180 \mathrm{Kg} .\end{array}$ & $\begin{array}{l}\text { Komagata, S. } \\
\text { et al. (1970) }\end{array}$ \\
\hline & Iceland & Reykholar & Drying seaweed & $80 \mathrm{R} / \mathrm{sec}$ at $100^{\circ} \mathrm{C}$ & $={ }^{t+} 21.8$ & Drying seaweed for export & $\begin{array}{l}\text { Matthiasson, M. } \\
(1970)\end{array}$ \\
\hline
\end{tabular}

* Where $1 \mathrm{MW}=238.9 \times 10^{3} \mathrm{cal} / \mathrm{sec}$.

+ Where $2 \times 10^{-4} \mathrm{MW}$ of power are required $/ \mathrm{m}^{2}$ of greenhouse.

${ }^{+\dagger}$ Where $\mathrm{MW}=\left(\right.$ temp of water ${ }^{\circ} \mathrm{C}-$ Discharge temp $\left.\left(35^{\circ} \mathrm{C}\right)\right)\left(\right.$ rate of flow $(\mathrm{ml} / \mathrm{sec})\left(4.186 \times 10^{-6} \mathrm{MW}-\mathrm{sec} / \mathrm{ca} 1\right)$ 
of somewhat saline geothermal waters via transfer of heat to water to be used directly on the crops. Heat exchangers used in this way do require a supply of fresh water and do perform with a low heat-exchange efficiency. Nevertheless, an increasing number of heat exchanger operations are being planned for areas where hothouse agriculture is needed, but pure geothermal waters are not available, e.g., Hungary.

Little has been written about the design, construction and operation of geothermally heated greenhouses. However, Yarosh et al. (1972), have published conceptual designs for hothouses heated by the waste-heat discharge from conventional source generating plants. Such designs should be consulted in planning a geothermal operation.

Animal Husbandry

The application of geothermal waters in animal husbandry is not as extensive as for greenhouse operations. However, this use is more diverse in that the geothermal fluids are not used exclusively for heating, but rather also for cleaning, sanitizing and drying of animal shelters and wastes. Poultry, swine and cattle respond to an optimal thermal environment with increased production, growth rate and feeding efficiency (Yarosh, et al., 1972).

Only recently have the optimum thermal-environmental conditions for these species at various stages of growth been determined. Therefore, the adoption of such techniques is limited, and such specific technical geothermal applications are minimal. Nevertheless, in Hungary, 203 MW of geothermal energy is currently being used to increase the production of these species. In Japan, a most exotic use of geothermal waters for animal husbandry is in the maintenance of optimal temperature condition for alligator and crocodile breeding.

\section{Aquaculture}

Much of the world protein requirements are filled by the consumption of aquatic species, most particularly fish. It is recognized that current conventional gathering methods and practices will result in smaller future yields because of currently increasing harvests, and the extended period of time required for wild species to attain marketable size. Therefore, attention is currently focussed on development of techniques for aquaculture. Aquaculture is the practice of cultivating aquatic species under controlled environmental conditions in order to establish and 
maintain optimal environmental conditions year-round for increased rate of growth and feed efficiency. Such cultivation of a large density of fish, for instance, in a limited area, is made possible by a continuous flow of water which carries in fresh oxygen and food and carries out waste material. Aquatic species respond extremely well to optimal environmental condition as evidenced by studies showing that under such circumstances, growth and feeding efficiency increase by as much as ten times (Marcello and Strawn, 1972).

\section{Summary}

\section{Experimental investigations of} optimum environmental conditions for greenhouse, animal husbandry and aquaculture operations has been underway for less than a decade. The motive for such studies has been to find suitable application for the low temperature thermal waste discharge. A report by Yarosh, et al., (1972) summarizes the extent and implementation of the investigation of the agricultural and aquacultural uses of wasted heat energy.

\section{INDUSTRIAL APPLICATIONS OF GEOTHERMAL ENERGY}

\section{Introduction}

Industry requires energy in a wide variety of forms. Three major categories of energy uses in the industrial sector are electrical energy, direct heat, and process steam. Electrical energy is required for electric-mechanical drives, electrolysis, and high-temperature heating, among other applications. Direct heating refers to the application of heat to a process without intermediate energy conversion. Typically, directheat applications require high temperatures - above $300^{\circ} \mathrm{C}$ and sometimes as high as $1000^{\circ}-1500^{\circ} \mathrm{C}$. Process steam applications include both direct use of steam in a process and the use of steam for heating.

\section{Geothermal-energy sources have} the potential to contribute substantially to these industrial needs. While it is not likely that geothermal sources will satisfy the requirements of many direct-heat applications, there is much current interest in the development of geothermal sources to provide electrical energy. These are discussed fully elsewhere. There is still another area in which geothermal sources have a large contribution to make: they can provide substantial amounts of process steam for industrial applications. Applications include simple process heating, evaporation, drying, distillation, refrigeration by absorption machines, sterilization, washing, and de-icing (as for mining operations). 
In addition to the potential. applications of the supply of energy to industry, geothermal resources may also have great importance to industry because of the raw materials they contain. Salts and other valuable chemicals are contained in geothermal waters, and some useful volatile substances may accompany the geothermal steam in the form of non-condensible gases.

While there are many potential industrial applications for the use of geothermal energy, the number of industrial applications presently using geothermal energy is relatively sma11. Table 6 lists the reported examples of the use of geothermal resources in industry. Figure 18 shows the distribution of these examples throughout the world. Although the total number is quite small, the power assoclated with these applications is not insignificant, representing a total utilization of about 150 to $200 \mathrm{MW}$ of geothermal energy. Table 6 illustrates that although there are relatively few current industrial applications, they represent a fairly wide range of uses, from drying of fish, earth, and timber, to pulp and paper processing, and to chemical recovery and processing from the geothermal fluids. The two largest present industrial applications are a diatomaceous earth plant in Iceland and a pulp, paper and wood processing plant in New Zealand. These systems provide the best present examples of industrial geothermal energy use.

There are several excellent reports discussing tnese applications. Iindal (1973) reviews the highlights of both the pulp mill and the diatomaceous earth plant. Lindal (1970a), and Ragnars (1970) and Wilson (1969) include thorough discussions of the pulp mill. The accounts of these operations in this report have been taken largely from Lindal (1973, 1970), Ragnars (1970), and Smith (1970). The accounts are presented here to (1) illustrate how some major geothermal developments have proceeded in the past, (2) to serve as a partial guide of what might be expected, particularly in lead time, if a large industrial use is contemplated, and (3) to show how versatile geothermal energy can be. Pulp, Paper and Wood Processing

The pulp, paper and wood processing plant of the Tasman Pulp and Paper Company, located in Kawerau, New Zealand, was the first major industrial development to utilize geothermal energy. The plant site was selected because of the availability of geothermal energy. Geothermal exploration at Kawerau started 


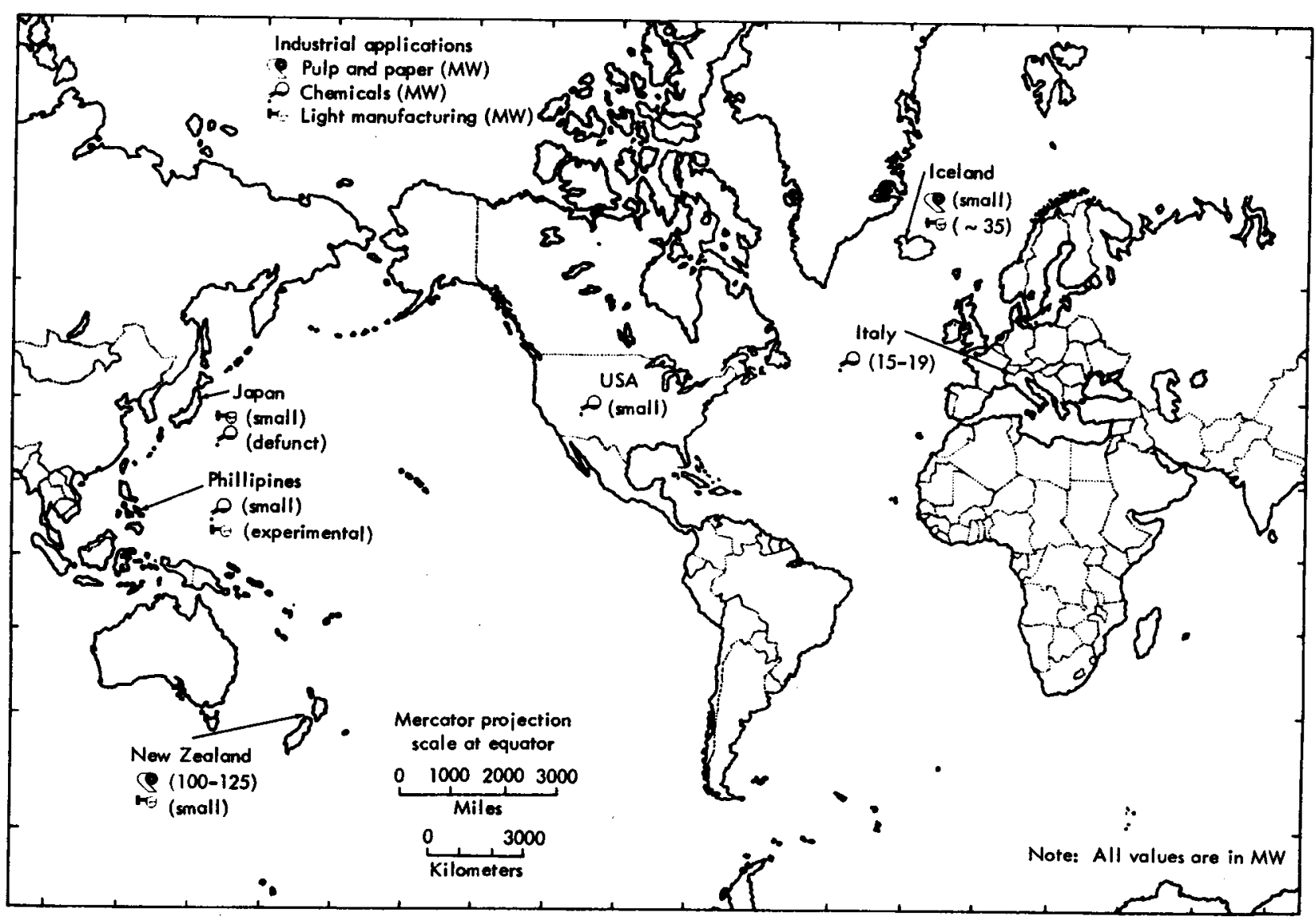

Fig. 18. Industrial applications in various geothermal regions. Detalls of these applications can be found in Table 6 . The present major industrial uses of geothermal resources are at the Tasman Pulp and Paper Mill, Kawerau, New Zealand and at the Kisilidjan h/f Diatomaceous Earth Plant, Lake liyvatn, Iceland.

in 1952 with the main purpose of locating and developing the geothermal resource for use in a projected pulp and paper mill. Preliminary drilling was done between 1952 to 1955, and in 1956 and 1957, seven wells were drilled that had good initial outputs. One of the wells was harnessed in 1957 to supply steam for timber drying in kilns and for use in the woodpreparation plant, with the remaining wells planned to serve pulp- and paper- mill use intended to begin in 1960. During testing by continuous discharge in the period 1958 to 1960, the outputs of the wells decreased substantially due to calcite deposits on the casing walls and, probably more important, due to the invasion of cooler water at production horizons. During the same period the steam mains and equipment for utilizing the output from the wells was nearing completion. In 1960, it was decided 
Table 6. Present industrial applications of geothermal energy.

\begin{tabular}{|c|c|c|c|c|}
\hline Application & Country & Localities & $\begin{array}{l}\text { Description of } \\
\text { application }\end{array}$ & $\begin{array}{l}\text { Production, } \\
\text { steam flow rate, } \\
\text { or water flow rate }\end{array}$ \\
\hline \multicolumn{5}{|c|}{ Wood \& Paper Industry } \\
\hline Pulp \& Paper & New Zealand & Kawerau & $\begin{array}{l}\text { Processing and a } \\
\text { small amount of } \\
\text { electrical power } \\
\text { generation. Kraft } \\
\text { process used. }\end{array}$ & $\begin{array}{l}\sim 400,000 \mathrm{lbs} / \mathrm{hr} \\
\text { of steam. }\end{array}$ \\
\hline
\end{tabular}

\section{Associated}

power
$(\mathrm{MW})^{\star}$

\section{Neweer Zealand Rotorua}

Washing \& Iceland

Hveragerdi Drying of Wood (Hengill area)

Steam drying

Mining

$\begin{array}{lll}\begin{array}{l}\text { Diatomaceous } \\ \text { Earth Plant }\end{array} & \text { Iceland Namafjall } & \begin{array}{l}\text { Production of } \\ \text { dried diatoma- } \\ \text { ceous earth } \\ \text { recovered by } \\ \text { wet-mining } \\ \text { techniques. }\end{array} \\ \therefore & \end{array}$

$\therefore$

Chemicals

\begin{tabular}{|c|c|c|c|}
\hline Salt Plant & Japan & $\begin{array}{l}\text { Shikabe, } \\
\text { Hokkaido }\end{array}$ & $\begin{array}{l}\text { Production of } \\
\text { salt from sea } \\
\text { water. }\end{array}$ \\
\hline
\end{tabular}

\begin{abstract}
Up to 50 tons per hour of steam at

$183^{\circ} \mathrm{C} / 10$ atg.

Total steam consump-

tion 40 to 50 tons/

hr according to the

season. Wellbore

flow - $184.8 \mathrm{Gcal} /$

hr. Utilized -

$30.5 \mathrm{Gcal} / \mathrm{hr}$.
\end{abstract}

-150 tons salt/year
100 to 125

Geothermal energy delivered to mills by $80,000 \mathrm{lb} / \mathrm{hr}$ o $200 \mathrm{psig}$ steam and 320,000

$\mathrm{lb} / \mathrm{hr}$ of $100 \mathrm{psig}$ steam

which are obtained by

flashing wet steam at the wellbore.

No details given.

Burrows (1970)

No details given.

Burrows (1970)

No details furnished. Reported to occur in other places.

Linda1 (1961a)

Dredging in the lake is done only in the summer while the plant runs throughout the year. The reported $30.5 \mathrm{Gcal} / \mathrm{hr}$ reported $30.5 \mathrm{Gcal} / \mathrm{hr}$ superheated steam at 10 atg.

Lindal (1973), Ragnars et a1. (1970), Linda

(1970b)
No longer in operation.
Komagata, et al. (1970) 
Table 6. (cont)

\begin{tabular}{|c|c|c|c|c|c|c|c|}
\hline Application & Country & Locallties & $\begin{array}{l}\text { Description of } \\
\text { application }\end{array}$ & $\begin{array}{l}\text { Production, } \\
\text { steam flow rate, } \\
\text { or water flow rate }\end{array}$ & $\begin{array}{l}\text { Associated } \\
\text { power } \\
(M W)^{\star}\end{array}$ & Comments & Reference. \\
\hline \multicolumn{8}{|c|}{ Chemicals (cont) } \\
\hline Sa1t Plant & Phlllipines & Tiwi, Albay & $\begin{array}{l}\text { Production of } \\
\text { salt from sea } \\
\text { water. }\end{array}$ & & $<2.5$ & $\begin{array}{l}\text { Sea water brought } 3 \mathrm{~km} \text { to } \\
\text { plant. Three grades of } \\
\text { salt produced. }\end{array}$ & $\begin{array}{l}\text { See } \\
\text { Appendix E }\end{array}$ \\
\hline $\begin{array}{l}\text { Sulphur } \\
\text { Mining }\end{array}$ & Japan & & $\begin{array}{l}\text { Sulfur extraction } \\
\text { from the gases } \\
\text { issuing from a } \\
\text { volcano. }\end{array}$ & & & $\begin{array}{l}\text { Unsophisticated operation } \\
\text { that has become uneconomic. }\end{array}$ & $\begin{array}{l}\text { Komagata, et al. } \\
(1970)\end{array}$ \\
\hline $\begin{array}{l}\text { Calcium } \\
\text { Chloride }\end{array}$ & $\begin{array}{l}\text { United } \\
\text { States }\end{array}$ & $\begin{array}{l}\text { Imperial } \\
\text { Valley, CA }\end{array}$ & $\begin{array}{l}\text { Recuvery of } \\
\text { potassium } \\
\text { chloride from } \\
\text { the geothermal } \\
\text { brine. }\end{array}$ & $\begin{array}{l}\text { Uncertain but } \\
\text { small. }\end{array}$ & & & Muffler (1973) \\
\hline Boric Actd & Italy & Larderello & $\begin{array}{l}\text { Geothermal steam } \\
\text { is used for pro- } \\
\text { cessing imported } \\
\text { ores. }\end{array}$ & 30 tons steam $/ \mathrm{hr}$ & -15 to 19 & & Lindal (1973) \\
\hline $\begin{array}{l}\text { Boric Actd, } \\
\text { Ammonium } \\
\text { Bicarbonate, } \\
\text { Ammonium } \\
\text { Sulphate, } \\
\text { Sulphur }\end{array}$ & Italy & Lardere110 & $\begin{array}{l}\text { Includes recovery } \\
\text { of substances } \\
\text { from the volatile } \\
\text { components which } \\
\text { accompany the } \\
\text { geothermal steam. }\end{array}$ & $\begin{array}{l}\text { No longer in } \\
\text { operation. Large } \\
\text { production before } \\
1966 .\end{array}$ & & & $\begin{array}{l}\text { Muffler }(1973) \\
\text { Mazzoni }(1948) \\
\text { Garlado }(1961) \\
\text { Lenzi }(1964)\end{array}$ \\
\hline Dry Ice & $\begin{array}{l}\text { United } \\
\text { States }\end{array}$ & $\begin{array}{l}\text { Imperial } \\
\text { Valley, CA }\end{array}$ & $\begin{array}{l}\text { Production of dry } \\
\text { ice from } \mathrm{CO}_{2} \text { in } \\
\text { the Salton Sea } \\
\text { geothermal area. }\end{array}$ & & & & Muffler (1973) \\
\hline
\end{tabular}


Table 6. (cont)

\begin{tabular}{|c|c|c|c|c|c|c|c|}
\hline Application & Country & Localities & $\begin{array}{l}\text { Description of } \\
\text { application }\end{array}$ & $\begin{array}{l}\text { Production, } \\
\text { steam flow rate, } \\
\text { or water flow rate }\end{array}$ & $\begin{array}{l}\text { Associated } \\
\text { power } \\
(M W)^{*}\end{array}$ & Comments & Reference \\
\hline \multicolumn{8}{|l|}{ Miscellaneous } \\
\hline $\begin{array}{l}\text { Confectionary } \\
\text { Industry }\end{array}$ & Japan & $\begin{array}{l}\text { Kannawa, } \\
\text { Beppu, Oita }\end{array}$ & & $\begin{array}{l}\text { Daily rice processing } \\
\text { capacity } 180 \mathrm{~kg} \text {. }\end{array}$ & & $\begin{array}{l}\text { Few details given, uses } \\
98^{\circ} \mathrm{C} \text { water, spring source. }\end{array}$ & $\begin{array}{l}\text { Komagata, et al. } \\
(1970) \text {. }\end{array}$ \\
\hline Grain Drying & Phillipines & Tiwi, Albay & $\begin{array}{l}\text { Geothermal steam } \\
\text { heats rotary kiln } \\
\text { dryer. }\end{array}$ & & -2.5 & $\begin{array}{l}\text { Palay drying time cut to } \\
10 \text { minutes from } 4-8 \mathrm{hrs} \text {. } \\
\text { Model under test. }\end{array}$ & See Appendix E \\
\hline $\begin{array}{l}\text { Brewing \& } \\
\text { Distillation }\end{array}$ & Japan & Ibusuki & $\cdot$ & Uncertain but small & & $\begin{array}{l}\text { No details given. One } \\
\text { well used. }\end{array}$ & $\begin{array}{l}\text { Komagata, et al. } \\
(1970)\end{array}$ \\
\hline $\begin{array}{l}\text { Stock Fish } \\
\text { Drying }\end{array}$ & Iceland & Reykjavik & $\begin{array}{l}\text { Fish drying in } \\
\text { shelf dryers. }\end{array}$ & : & & $\begin{array}{l}\text { Uses excess water from } \\
\text { commercial heating system } \\
\text { in keykjavik during summer } \\
\text { in local stock fish pro- } \\
\text { cessing center. }\end{array}$ & Lindal (1961a) \\
\hline $\begin{array}{l}\text { Curing Cement } \\
\text { Building Slabs }\end{array}$ & $s^{\text {Iceland }}$ & & $\begin{array}{l}\text { Curing of light } \\
\text { aggregate cement } \\
\text { building slabs }\end{array}$ & $\cdot$ & & $\begin{array}{c}\text { No dutails given. } \\
\vdots \\
\text {. }\end{array}$ & Lindal (1973) \\
\hline $\begin{array}{l}\text { Washing } \& \\
\text { Drying of } \\
\text { Wool }\end{array}$ & v & & & & & $\begin{array}{l}\text { No details given. Reportid } \\
\text { to occur in two or more } \\
\text { countrics. }\end{array}$ & Lindal (1973) \\
\hline Seaweed & Iceland & Reykholar & $\begin{array}{l}\text { Drying seaweed } \\
\text { for export. }\end{array}$ & $\begin{array}{l}80 \mathrm{~s} / \mathrm{sec} \text { at } 100^{\circ} \mathrm{C} . \\
\text { Production of } 3600 \\
\text { tons of dry seaweed } \\
\text { per year. Each ton } \\
\text { requires } \$ 3.40 \text { worth } \\
\text { of energy per ton of } \\
\text { seaweed if the energy } \\
\text { costs } \$ 0.45 \text { per Gcal. }\end{array}$ & 3 to 4 & $\begin{array}{l}\text { Description of proposed } \\
\text { system given; there is only } \\
\text { word-or-mouth indication } \\
\text { that system is presently } \\
\text { in operation. }\end{array}$ & $\begin{array}{l}\text { Matthiasson } \\
(1970)\end{array}$ \\
\hline
\end{tabular}

* The "associated power (MW)" entry is an estimate of the rate at which energy is supplicd to and available to be utilized by the process, usually not the energy flow rate from the wellbore. 
to drill some of the wells to a greater depth (Dench, 1962). The deepening was quite satisfactory for three of the four holes and these along with one of the other wells which had not been deepened, were put into immediate service in the pulp and paper operation. Except for variable flow due to periodic exhaustion of the local reservoir in one of the wells and calcite deposits in all of the wells, these wells have provided a good source of energy to the plant, and as of 1969 , supplied about $60 \%$ of the geothermal steam. In 1967, additional wells were drilled much further away from the mills. These new wells account for the remaining $40 \%$ of the geothermal steam production. Figure 19 shows the layout of the Kawerau steam field and the pulp, paper, and wood processing plant. Table 7 lists the steam production of the various wells that were supplying steam as of August, 1969.

The plant receives steam from the geothermal wells in two lines. A 12-inch pipeline, with a capacity of $80,000 \mathrm{lb} / \mathrm{hr}$., delivers steam at a pressure of 200 psig from well KA8. A 24-inch pipeline, operating at a pressure of $100 \mathrm{psig}$, has a capacity of $320,000 \mathrm{lb} / \mathrm{hr}$. It serves two purposes: it delivers steam obtained by flashing the hot water at well
Table 7. Steam production from wells at Kawerau (August, 1969). (Smith, 1970)

\begin{tabular}{lcc}
\hline Well no. & $\begin{array}{c}\text { Pressure } \\
\text { (psig) }\end{array}$ & $\begin{array}{c}\text { Steam } \\
\text { out put } \\
\left(10^{3} \text { lb/hr) }\right.\end{array}$ \\
\hline $7 \mathrm{~A}$ & 100 & 30 \\
8 & 200 & 130 \\
8 (flash) & 100 & 30 \\
14 & 100 & 24 \\
16 & 100 & 125 \\
17 & 100 & 30 \\
\hline
\end{tabular}

Due to pressure drop in the pipelines, wellhead pressures are somewhat higher than shown.

KA8, and it collects steam from all the other producing wells. Present operations at all wells involve flashing the wet steam at the well bore and transmitting only the dry steam.

The high-pressure steam at 200 psig is used directly for timber drying and for the operation of log-handling equipment. It is also used to generate 150 psig clean steam in a $55,000 \mathrm{lb} / \mathrm{hr}$ steam generator. The clean steam is primarily used in the pulp-digestion process. Any surplus high-pressure steam is fed into the low-pressure line.

The low-pressure steam at 100 psig is used in another steam generator for producing a $45,000 \mathrm{lb} / \mathrm{hr}$ capacity of 50 psig clean steam and for several direct uses, with the surplus going 


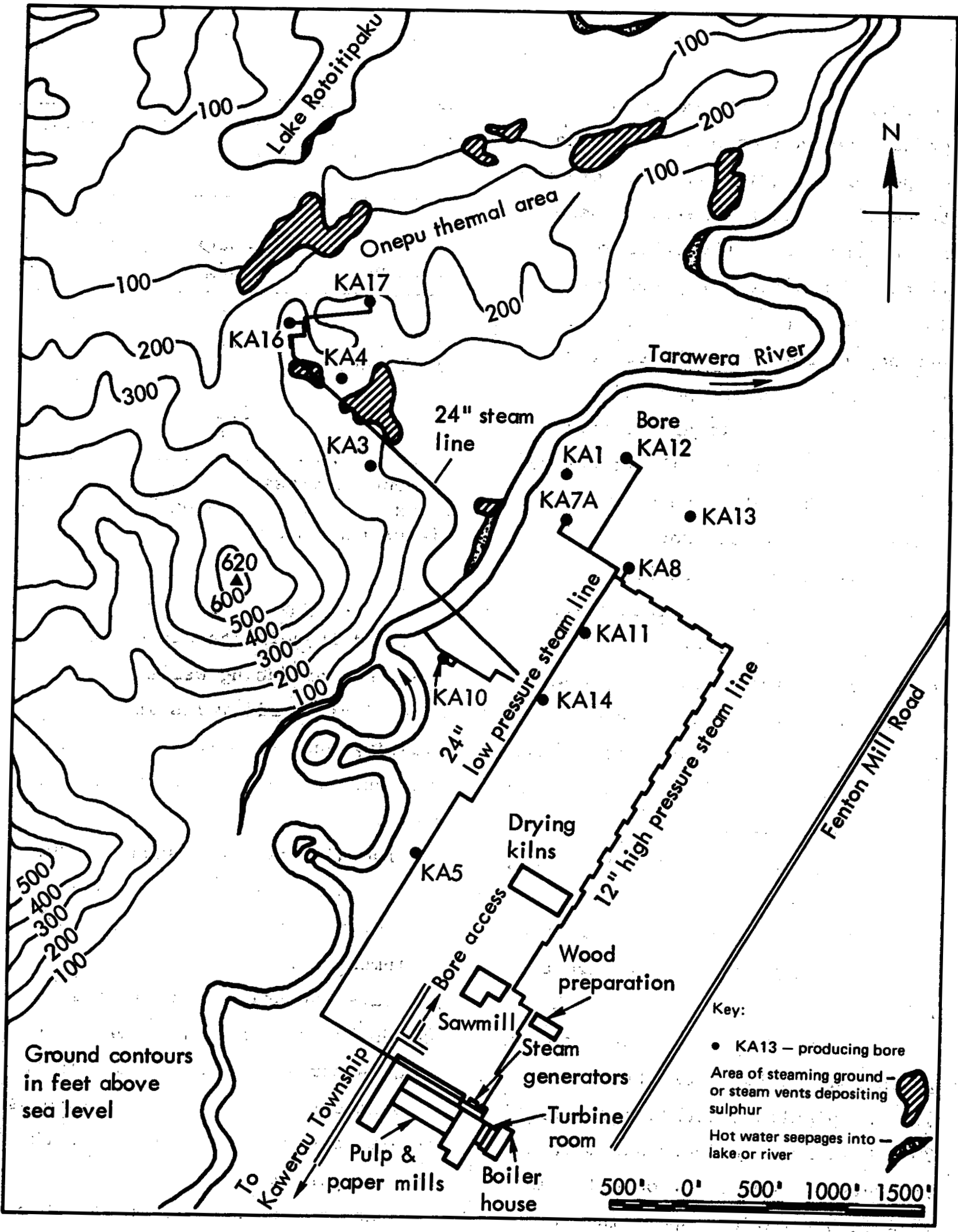

Fig. 19. Kawerau geothermal field layout; illustrating plant location, main steam piping and well locations. Geothermal steam via a high pressure line is used for timber drying, log handling equipment; and to generate through heat exchange $150 \mathrm{psig}$ of 'clean steam. Lowpressure geothermal steam is used to generate clean steam also (50 psig) and to drive a $10 \mathrm{KW}$ non-condensing turbo-alternator. 
to a $10 \mathrm{MW}$ non-condensing turboalternator exhausting the atmosphere. Up to $100,0001 \mathrm{~b} / \mathrm{hr}$ of this exhaust steam is used in the black 1iquor preevaporator. This turbo-alternator operates in parallel with other units fed with boiler steam and, also, with the external power supply. If the external power supply fails, the geothermal turbine takes preference in the demand for steam, which may be as much as $319,000 \mathrm{lb} / \mathrm{hr}$ while the turbine is generating its rated output.

In addition to the use of geothermal steam, conventional boilers burning either black liquor from the kraft pulp process, wood waste and/or coal or oil supply $350,000 \mathrm{lb} / \mathrm{hr}$ of high pressure steam at 650 psig and $400^{\circ} \mathrm{C}$. The bulk of the firing is from the black 11quor and wood waste, with the coal or oil being merely used as a supplement and for emergencies. Most of the electricity used within the mills is produced from this high-pressure steam.

The pulp and paper industry appears to be one of the more desirable potential geothermal applications because this industry has large requirements for steam in the range of 30 to 150 psig yet has relatively small electricity requirements. Note, however, that the pulp and paper industry cannot obtain the major portion of its steam in the manner of, for example, such industries as those producing chlorinecaustic soda and synthetic soda ash, which generate most or all of their electricity and can obtain their lowpressure steam efficiently from either extraction or waste-heat recovery units.

\section{Diatomaceous-Earth Plant}

The production of diatomaceous earth at Namafjall, Iceland, utilizing geothermal energy is an important development for geothermal energy in industrial applications, not only because it is a currently operational larger scale application, but also because it serves as an example of the way in which cheap geothermal energy can make a process economic when, with conventional energy resources, the process could not be just if ied.

Following the discovery of rich deposits of high-grade diatomite on the bottom of Lake Myvatn, technical and economic studies indicated that only by the use of potentially cheap geothermal energy from the nearby Namafjall high-temperature geothermal field could the recovery and drying of the diatomite be competitive with conventional diatomite production from comparatively dry land.

Earlier exploration in the Namafjall area was confined to shallow 
wells drilled between 1947 and 1953, when there was interest in sulfur separation from geothermal steam. In 1963, exploratory geothermal drilling began. While the first two exploratory wells were not very satisfactory, development continued and in 1966 the first producing well was brought in. In late 1967, Kisilidjan h/f began operation of their diatomaceous earth plant, with a production rate of 12,000 tons/yr. Additional producing geothermal wells were drilled in 1968 and 1969. Iceland's first geothermal power plant (a pilot unit of $3 \mathrm{MW}$ capacity) was brought into operation in 1969, using steam from this field. In 1970, the diatomaceous earth plant was expanded, production increasing to 24,000 tons/yr. Figure 20 shows the layout of the wells, diatomaceous earth plant, main steam lines, and the pilot power plant. The geothermal fluid at the well bore has an average enthalpy of $260 \mathrm{kcal} / \mathrm{kg}$ which corresponds to saturated water at $250^{\circ} \mathrm{C}$ and a pressure of at least 579 psia. The fluid is flashed to provide saturated steam at 10 atg pressure that is transmitted to the earth plant and the power plant.

Figure 21 illustrates where geothermal steam is used at the diatomaceous earth plant. The drying process uses the greatest amount of steam, about 30 tons per hour at the present production rate. The drying

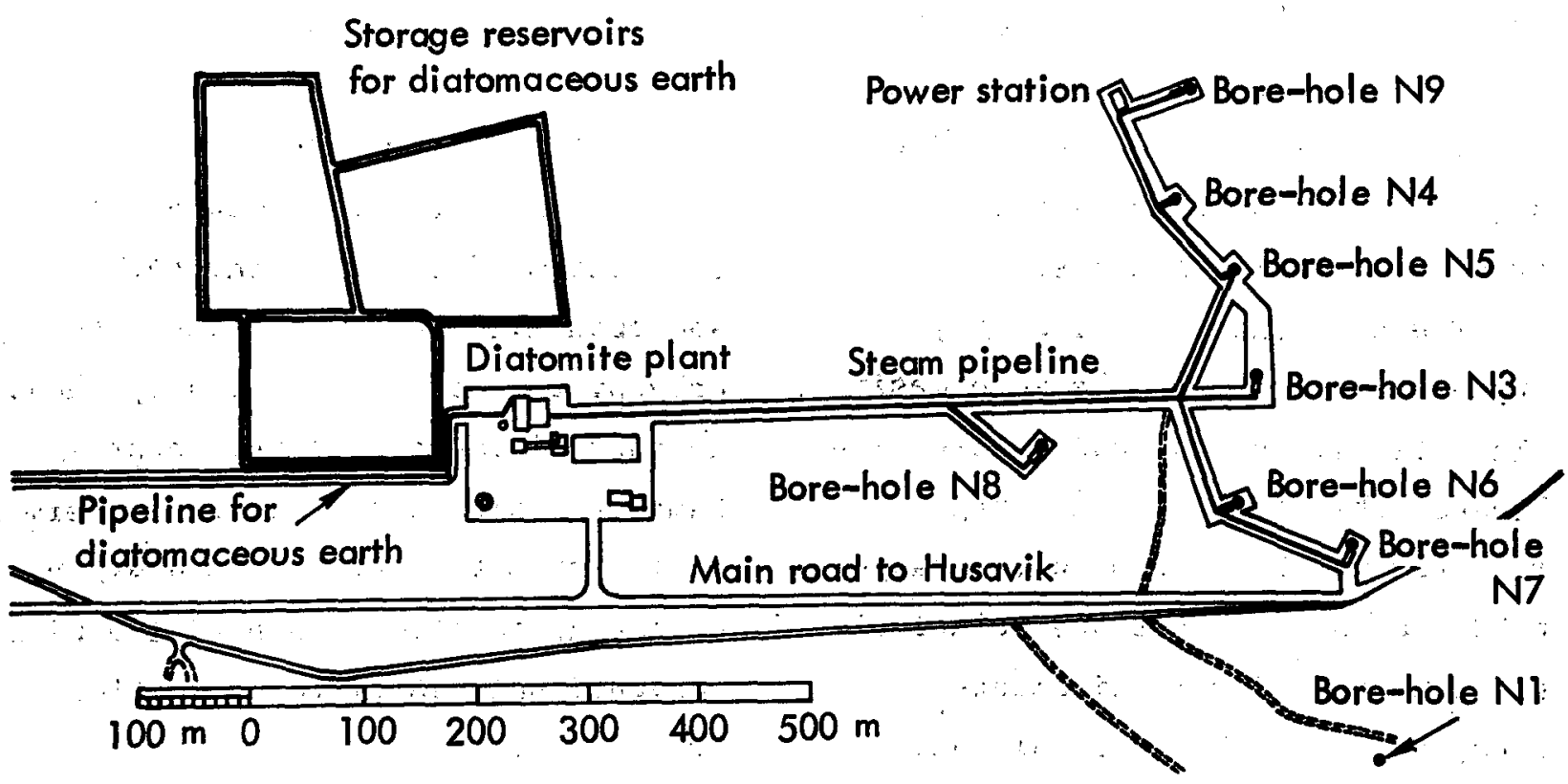

Fig. 20. Layout of the boreholes, diatomite plant and power station in the Namafjall geothermal area of Iceland. (Lindal, 1970b) 


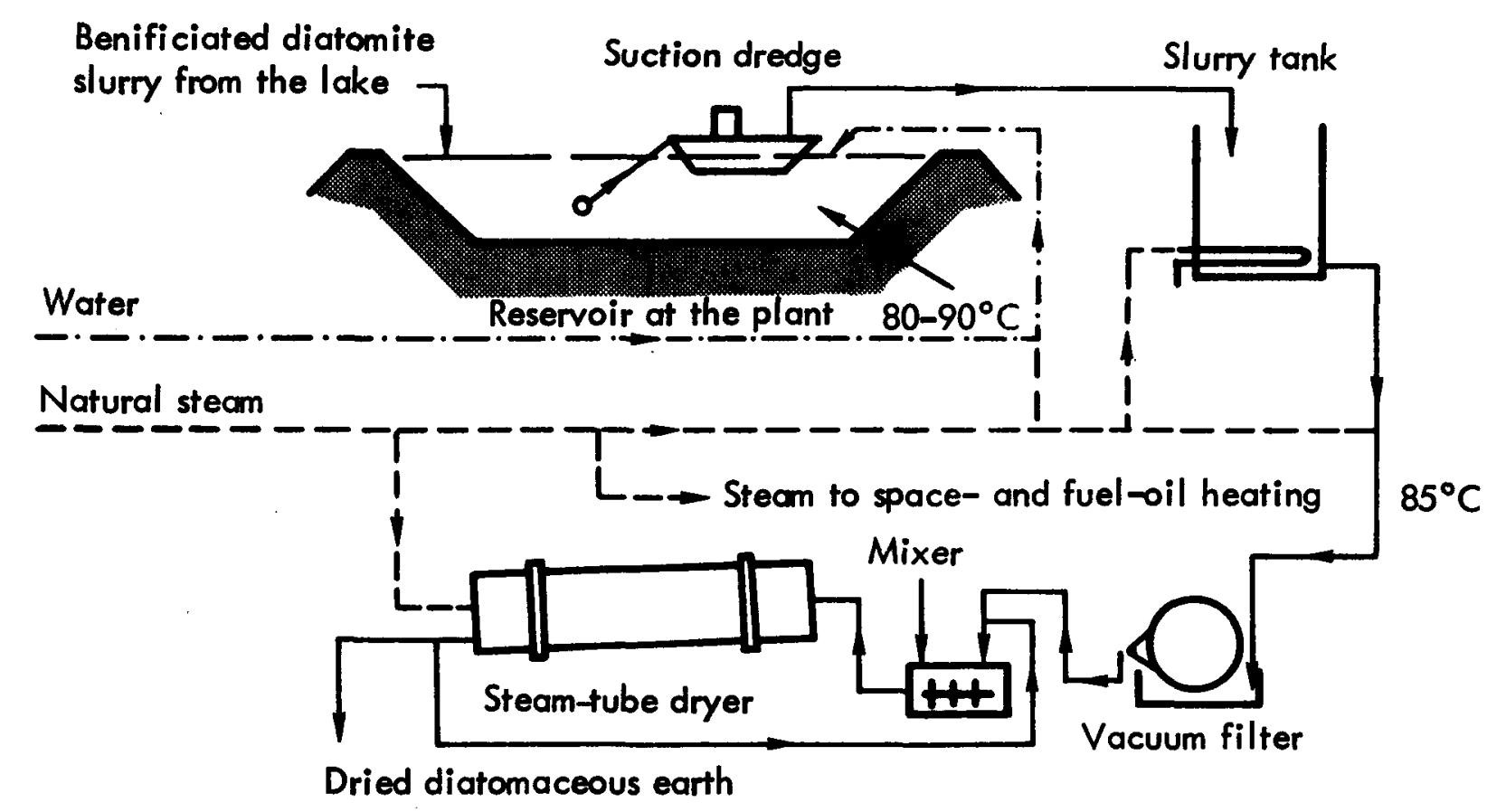

Fig. 21. Flow diagram of the "wet end" of a diatomaceous earth plant illustrating where geothermal steam and water are used. Hot water keeps the beneficiated diatomite slurry reservoir from freezing during operations in winter. Steam is used for keeping the slurry tank from freezing, for space- and fuel-oil heating and, for the most part, in drying the diatomite slurry in steam tubes.

process is also the process which dictates the minimum allowable steam conditions for the delivery from the single main steam line, demanding about $10 \mathrm{atg}$ for the dryers that were added in the 1970 expansion. Because dredging in Lake Myvatn cannot take place throughout the entire year, reservolrs are located at the plant for holding beneficiated diatomite slurry from the lake. The daily supply to the plant comes from a suction dredge which operates in the local reservoir. To permit operation of the dredge throughout the year, geothermal steam is used to heat warm water available at the plant site at $30^{\circ} \mathrm{C}$ to 80 or $90^{\circ} \mathrm{C}$ which is then discharged around the dredge and floating pipeline during the winter. This use requires about 7 tons/hr during the winter. Steam is also used to keep the slurry from freezing in the slurry tank and for heating the slurry by direct injection of geothermal steam. The heating requirement amounts to about 8 tons/hr of steam use. Additional requirements for space heating, heating of heavy fuel oil required for calcination, 
and miscellaneous uses amount to about 5 tons/hr during winter operation. Table 8 summarizes the usual winter use of steam In the diatomaceous earth plant.

Apparently, the only troubles associated with the use of geothermal energy for this application were the clogging of steam traps and bleed vents, and the silica deposition on the heat-exchange surfaces of the dryers and on steam valves. A11 problems have been solved, primarily by small redesigns and keeping the water content of the steam to a minimum.

This plant consumes about 50 tons/ hr of 10 atg steam during winter operations. About 273 tons/hr of

Table 8. The use of geothermal steam in the diatomite plant at Namafjal, Iceland (Lindal, 1970b).

For the dryers

Slurry heating

Deicing of reservoirs in the winter

Slurry tank, fuel oil heating and space heating

For extra use Total supply

Note: 'Value's represent approximate winter use. Summer requirements maybe as low as 40 tons/hour. $183^{\circ} \mathrm{C}$ water are also produced at the wellhead and are discarded after flashing of the steam. As much as $10-15$ tons/hr of the steam requirement could be satisfied by use of this hot water if it were possible to transport it to the application site. Although it is not economic to build a pipeline solely to bring the hot water to the plant, such a project should be considered at the time of any future expansion as an alternative to additiona $1_{\text {, steam }}$ lines. Another option would be to transport the twophase fluid, both steam and hot water, to the plant. Such a system is being studied in New Zealand (James et al., 1970).

\section{Investigated Potential Uses}

Table 6, which indicates the present industrial applications of geothermal energy, does not really do justice to reporting the activity in exploring industrial applications for geothermal energy. To give a more realistic view of this activity, Table 9 is presented to show the industrial applications that have been studied but are not presently. in production. Some of the applications have received substantial and detailed study while others have only had cursory consideration.

In closing this discussion of industrial applications of geothermal 
Table 9. Potential industrial uses of geothermal energy which have been investigated but are not presently in commercial production.

\begin{tabular}{|c|c|c|c|}
\hline Application & Description & Comment & References \\
\hline Heavy water production & $\begin{array}{l}\text { Production of heavy water by } \\
\text { the hydrogen sulphide-water } \\
\text { isotope exchange process. }\end{array}$ & $\begin{array}{l}\text { Good process for geothermal energy use since huge } \\
\text { quantities of steam are required per dollar of } \\
\text { product value and appears economic under proper } \\
\text { conditions. }\end{array}$ & $\begin{array}{l}\text { Valfells }(1970) \text {, Valfells } \\
\text { et al. }(1969) \text { and } \\
\text { Valfells }(1959) \text {. See } \\
\text { Appendix D. }\end{array}$ \\
\hline Fresh water production & $\begin{array}{l}\text { Production of fresh water from } \\
\text { either seawater or geothermal } \\
\text { flulds. }\end{array}$ & $\begin{array}{l}\text { Promising process because of large quantities of } \\
\text { energy required, but requires geographlc colncidence } \\
\text { of need for fresh water and geothermal sources. } \\
\text { Use of geothermal fluid itself is interesting } \\
\text { because of the already high enthalpy of the liquid. }\end{array}$ & $\begin{array}{l}\text { Bodvarsson (1961), Wong } \\
\text { (1970), Rex (1968, 1971). } \\
\text { Barnes (1971), Guiza } \\
(1974) \text {. }\end{array}$ \\
\hline \multirow[t]{5}{*}{ Recovery of chemicals } & $\begin{array}{l}\text { Recovery of salt from seawater } \\
\text { using geothermal energy. }\end{array}$ & $\begin{array}{l}\text { Found uneconomic. Also, novel scheme using glacial } \\
\text { ice. }\end{array}$ & Lindal (1961b), (1967). \\
\hline & $\begin{array}{l}\text { Multiproduct recovery from } \\
\text { seawater. }\end{array}$ & $\begin{array}{l}\text { Reference is largely a review of the possibilities } \\
\text { and points out the more prominent candidates for } \\
\text { recovery. }\end{array}$ & $\begin{array}{l}\text { Ludviksson and Linda } 1 \\
(1966)\end{array}$ \\
\hline & $\begin{array}{l}\text { Multiproduct recovery from } \\
\text { seawater and/or geothermal } \\
\text { brine. }\end{array}$ & $\begin{array}{l}\text { Reference discusses a sea-chemical complex and } \\
\text { emphasizes extraction of common salt, calcium } \\
\text { chloride, potassium chloride, and bromine from } \\
\text { geothermal brine in the Reykanes peninsula of } \\
\text { Iceland. Also considers magnesium chloride and } \\
\text { soda ash production. }\end{array}$ & Linda1 (1970a) \\
\hline & $\begin{array}{l}\text { Multiproduct recovery from } \\
\text { geothermal brine. }\end{array}$ & $\begin{array}{l}\text { Production of minerals and fresh water from the } \\
\text { geothermal brines in the Imperial Valley, U.S. }\end{array}$ & $\begin{array}{l}\text { Wong }(1970) \text {, Werner } \\
(1970)\end{array}$ \\
\hline & $\begin{array}{l}\text { Multiproduct recovery from } \\
\text { geothermal brine. }\end{array}$ & $\begin{array}{l}\text { References discuss the possibilities of future } \\
\text { chemical extraction from geothermal fluids in the } \\
\text { U.S.S.R. - bromine and iodine emphasized but } \\
\text { some reference is also given to alkaline metals, } \\
\text { boron, lithlum, and a few trace elements. }\end{array}$ & $\begin{array}{l}\text { Shcherbakow and Dvorov } \\
(1970), \text { Tikhonov and } \\
\text { Dvorov (1970), Makorenko } \\
\text { et a1. (1970), Sukharev } \\
\text { et a1. (1970) }\end{array}$ \\
\hline Alumina production & $\begin{array}{l}\text { Production of alumina from } \\
\text { bauxite via Bayers process. }\end{array}$ & $\begin{array}{l}\text { Not put in practice at time of study due to } \\
\text { unfavorable market and raw material conditions. }\end{array}$ & Lindal (1961a) \\
\hline
\end{tabular}


Table 9. (cont)

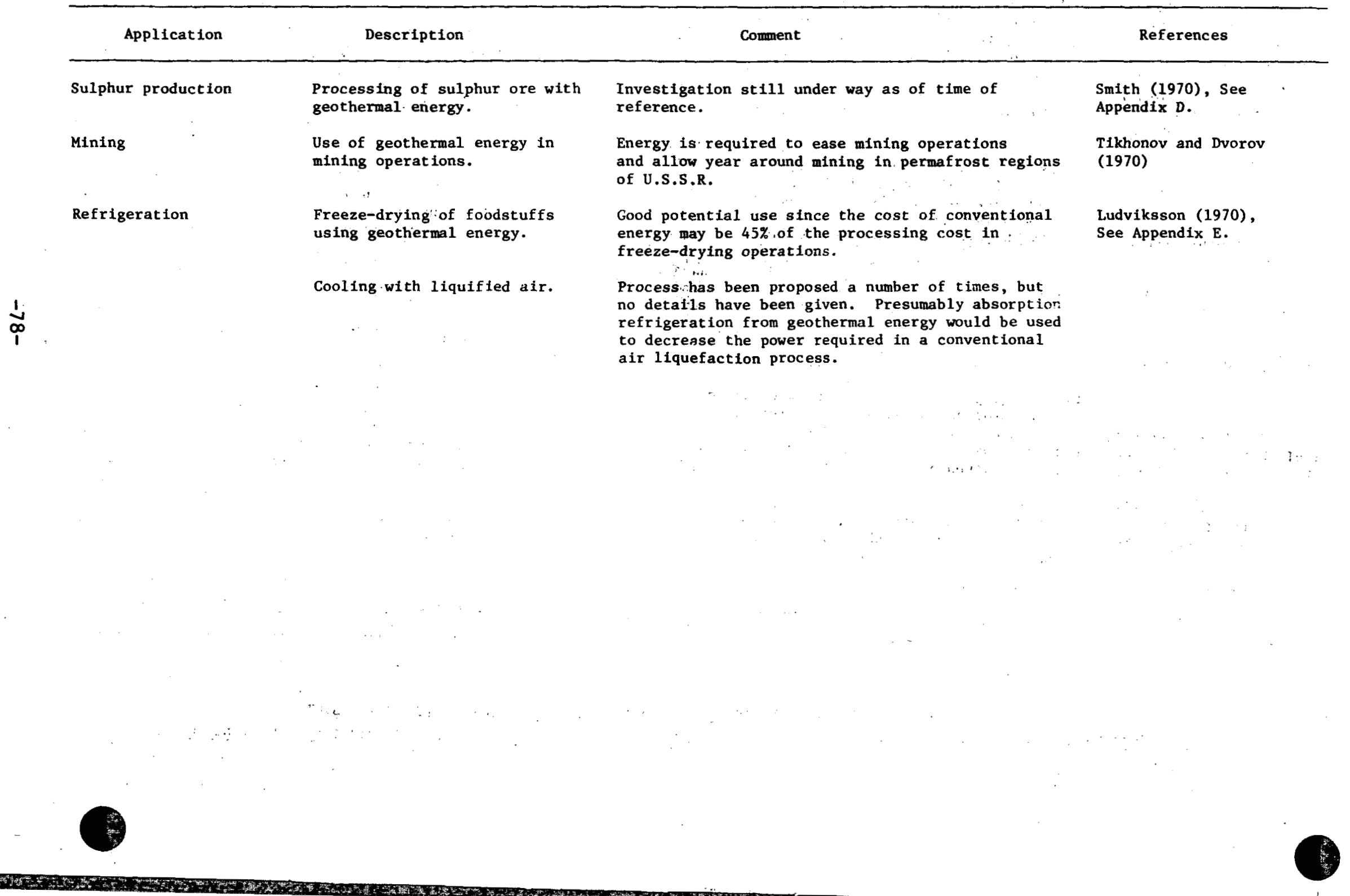


energy, let us consider the relative efficlencies associated with classes of potential applications. Ragnars et al., (1970) report that on the average the enthalpy in the Namafjall field is $260 \mathrm{kcal} / \mathrm{kg}$ and that the production of $110 \mathrm{ton} / \mathrm{hr}$ of steam at 10 atg pressure requires a total mass flow of 710 ton/hr at the wellhead. He then determines efficiencies of a number of potential applications; these are shown in Table 10 together with some typical fossil-fuel efficiencies. Two things are apparent from this table: (1) significantly

Table 10. Efficiency of utilization of geothermal energy in the Namafjall area of Iceland for some existing and potential processes

District heating (utilizing both steam and water) about $80 \%$

Industrial heating (utilizing the steam only)

about $35 \%$

Condensing turbines (utilizing the steam only)

about $12 \%$

Noncondensing turbines (utilizing the steam only)

about $4 \%$

Notes

1. Steam use is at 10 atg pressure.

2. Source: Ragnars et al., (1970).

Fossil fuel efficiencies for comparison: (1) process heating: $\sim 85 \%$; (2) electric power production: $36 \%$. greater efficiencies can be had if direct process heat can be used (primarily by avoiding the conversion losses inherent in cycles operating with low source temperatures); and (2) a very large amount of the total energy content is present in the water phase, i.e. the efficiency of heating using both steam and water is $80 \%$; using steam alone, it is $35 \%$. Clearly, applications where the geothermal energy can be used directly, and those where the total flow can be used have great promise for effective use of the resource.

Nonelectrical uses of geothermal energy of the type discussed in this report are inherently a more efficient use of the resource than energy conversion, which suffers from the low efficiency of the conversion machinery. Until the present time, relatively little has been done about utilization of geothermal steam and hot water directly in industrial processes; the rapid increase in fuel price and the increasing availability of geothermal energy sources should combine to spur further development along the lines outlined here.

Finally, many of the currently operational geothermal fields are using only the steam from the twophase systems of steam and hot water produced from the fields. A large fraction of the heat content of the 
systems is resident in the water, as exemplified by Namafjall. Thus, in each area where the water is not being used, there are excellent prospects for greater energy efficiency if a use can be found for this hot water.

\section{Economic Considerations}

\section{INTRODUCTION}

The purpose of this chapter is to present some generalizations about the economics of nonelectrical applications of geothermal resources. Costs of a series of hypothetical appilcations are illustrated and then compared with costs for satisfying the same application with fossil fuel energy resources.

Low-temperature (1.e., less than $250^{\circ} \mathrm{C}$ ) geothermal resources may have a major impact on the supply of energy espectally for residential commerical, and perhaps industrial users. Reistad (1975), for instance, notes that about $15 \times 10^{15} \mathrm{Btu}(25$ to $30 \%$ ) of total U.S. energy consumption is used in heating and cooling residences and commercial buildings. In addition, nearly half this amount of energy is used in low-temperature process steam industry. Furthermore, residential and commercial applications are expected to continue to be a significant user of energy in the future. By 1980, such uses are estimated to require roughly
$20 \times 10^{15}$ Btu. About three quarters of this energy is expected to be provided by natural gas and petroleum (Austin and Winter, 1973) and substitution of geothermal energy for fossil fuels frees these fossil fuels for uses that only they can satisfy, e.g., transportation, feedstock, etc. The possibility of such substitution for fossil fuels may become a very important consideration in efforts to balance supply and demand of energy resources in the future.

\section{ECONOMIC ANALYSIS}

\section{Sources of Costs Estimates}

A few cases for which cost data or estimates are readily avaliable have been selected in order to illustrate the economics of known or hypothetical nonelectrical geothermal applications. Possible uses and rates of energy use in residential and commercial applications have been guided by experience reported from Klamath Falls, Oregon, by Culver et al., 
(1974). Their experience is similar to that reported for Iceland (Zoega, 1974). Cost estimates of smaller shallow wells (In the range of $\$ 7000$ to $\$ 40,000$ per we11) are from Klamath Falls, also, as is the general estimated cost of distribution, namely, $\$ 2500$ per user. Distribution costs are estimated on the average per user as $\$ 2000$ for 100 feet of main line and $\$ 500$ per individual user service line. Cost estimates for an intermediate-depth resource are based on experience in the Imperial Valley, California, (U. S. Department of Interior, Bureau of Reclamation, 1974). Costs of deeper wells are those used by DSS Engineers, Inc. (1975) in their analysis of the possibility of using the geopressuregeothermal resource to service some of the energy needs of a pulp and paper mill located in the Gulf Coast of the United States. Their example is also used as an example of an industrial application based on a hot water resource.

\section{Initial Capital Costs}

Estimates of initial capital costs, including production and disposal wells and any associated distribution system, are listed in Table 11 . Well costs are high when the resource is deep (Table 11, examples 1 through 7). Furthermore, reinjection wells double the costs of a well system in the U.S. Gulf Coast and in the Imperial Valley (Table 11, examples 1 through 7). Reinjection wells are expected to be required in these areas and under similar circumstance in general. They are needed in the Imperial Valley so that effluent does not contaminate the agricultural environment, which is the basis of the economy there. They are needed in the Gulf Coast in order to dispose of the large flows needed to service a hypothetical pulp and paper mill. (Estimated flow rate is $3,500,000$ pounds per hour; cf. 400,000 pounds per hour for steam at the Kawerau, New Zealand, mill, see Fig. 19.) Distribution costs can also be significant (see Table 11, examples $5,7,10,11$, and 13).

\section{Annual Costs}

Annual costs include costs to amortize the original capital costs, operations and maintenance costs, taxes, and insurance. Amortization is assumed to take place over 30 years at a $10 \%$ interest rate. Annual amortization costs are equal to initial capital costs times the factor 0.1061 . Operating and maintenance costs are based on actual experience for Klamath Falls, and by arbitrarily using $5 \%$ of initial capital costs elsewhere. Pumping power costs are based on 
Table 11. Costs of geothermal systems.

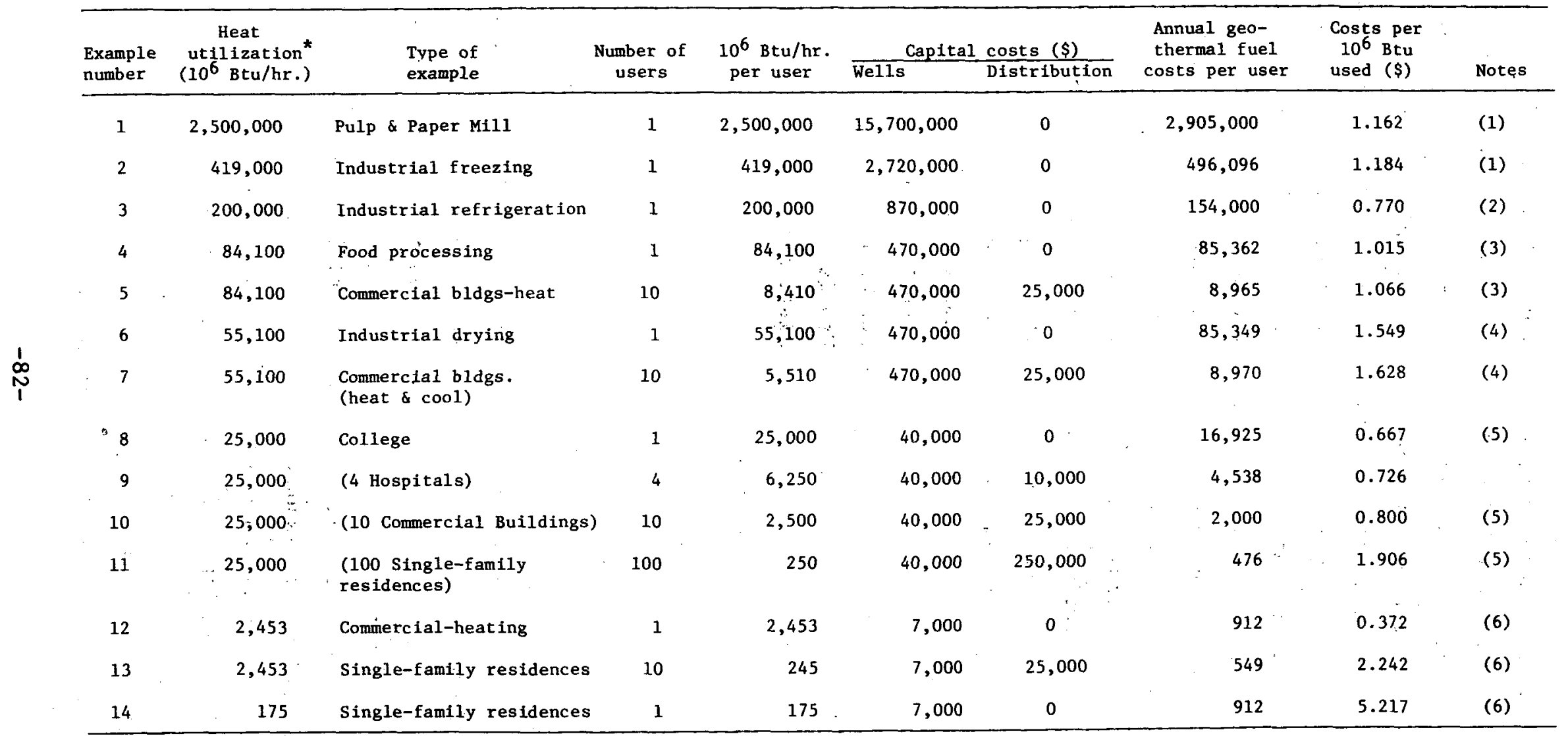

NOTES (1) ' $13,000^{\prime}$ ' deep $250^{\circ} \mathrm{F}$ U.S. Gulf Coast

(2) $8,500^{\prime}$ deep $180^{\circ} \mathrm{F}$ U.S. Gulf Coast

(3) $6,000^{\prime}$ deep $225^{\circ} \mathrm{F}$ Imperial valley

(4) 6,000' deep $225^{\circ} \mathrm{F}$ Imperial Valley

(5) Large System, Klamath Falls, Oregon $-\sim 190^{\circ} \mathrm{F}$

(6) Small System, Klamath Falls, Oregon $-190^{\circ} \mathrm{F}$

* Nôt to be confused with capacity of the system to produce heat energy; 1.e., this expresses heat actually used, rather than potential for providing heat. 
estimates from the Gulf Coast. Taxes are taken as $\$ 27$ per $\$ 1000$ of assessed valuation with assessed value set at $25 \%$ of initial cost. Annual insurance premiums are taken as $1 \%$ of initial capital costs. Costs per million Btu used is equal to annual costs divided by heat utilization. Heat used may not necessarily represent the heat that could be extracted from the well system. (This difference is important in considering the economics of nonelectrical applications, as noted below.)

In order to be compared to the costs of fossil fuels, which are quoted on a heat-of-combustion basis, fossil fuel prices must be inflated by an efficiency factor to approximate cost per heat unit used. Burning of fossil fuel is considered to be $2 / 3$ efficient, although it is often less. Accordingly, the equivalent cost of fossil fuel is equal to the quoted cost times the factor (1.5). Fuel costs are those quoted for Klamath Falls, in September, 1974. Costs shown are per million Btu, which is the approximate heat value of one MCF (standard thousand cubic feet) of natural gas. They vary from a low value of $\$ 0.372$ to $\$ 5.217$ as a high value and are listed in Table 11.

\section{Generalizations}

Some generalizations about the economics of nonelectrical applications are further illustrated in Table 11. First, underutilized well systems lead to higher per-unit heat costs when using geothermal resources for nonelectrical purposes. Assuming that the well systems in example pairs 4 and 6 and 12 and 14 have the same capacity, respectively (because the well systems for each pair cost the same), it should be noted that, quite obviously, those examples using less of the potentially available heat have higher per-unit heat costs (\$1.549 vs. 1.015 and $\$ 5.217$ vs. $\$ 0.372$ respectively). Second, distribution costs add to the per-unit heat cost of using geothermal resources for nonelectrical applications (examples 8 to 11 ). For small users, distribution costs can make a big difference (examples 11 and 13). In the examples ( 8 vs 11 ), the capital cost of the distribution is high and the per-user share of this cost is such as to increase the unit heat cost to $\$ 1.906$ whereas it could be only 0.677 for a user who did not require a major distribution system.

In examples 13 and 11 the cost of the distribution system is more than three times the well system. Even with large systems, distribution costs may tend to offset economies of scale (cf. examples 8 and 11). Third, costs for geothermal heating are 
below fossil fuel costs of $\$ 1.73$ per million Btu's except in three examples (examples 11, 13, and 14). "In one example, (14), the well is considered to be underutilized. In the other examples the costs of distribution dominate the unit heat costs (11 and 13). Finaliy, it appears that moderate capacity, shallow wells which are fully utilized lead to the cheapest costs (Example 12).

\section{Savings}

Table 12 emphasizes the savings that can be realized by using relatively less expensive geothermal resources in nonelectrical applications. Savings vary from a few hundred dollars per year to almost a million. It should be noted, however, that these savings are hypothetical and that investment in these uses will have to be justified in a way that includes the size of the capital costs and the risk associated with uncertainty in assessing the resource.

Should 'low-temperature' uses be possible downstream from an industrial user, multiple use of the same resource could improve the savings noted already.

For the industrial example cited: by DSS-Engineers, Inc. (1975), some electricity generation may be possible. The value of this energy over and above the costs to generate it should also be noted in calculating savings.

Finally, it should be pointed out that geothermal steam should be much more economical than hot water in terms of capital costs. For the geopressure geothermal example, heat content is $117 \mathrm{Btu} / \mathrm{lb}$ (DSS Engineers; Inc., 1975). Geothermal steam would have nearly 10 times this heat content and would require less than onetenth the disposal capacity.

The concept of a community modeled around a geothermal energy resource has been considered by a number of workers. Table 13 summarizes the possible benefits, and this table serves to further illustrate the savings possible with nonelectrical applications. They include annual replacement of $4.45 \times 10^{12} \mathrm{Btu}$ of fossil fuel and a dollar saving of over $\$ 1,250,000$.

\section{SUMMARY}

Geothermal heat is competitive with the lowest priced fossil fuel (natural gas) in residential and commercial heating applications and in industries where low temperature process heat is required. The : calculated potential savings are 23 to $86 \%$ of the cost of natural gas. :

Initial capital costs are quite high in single-family residential applications (as much as $10 \%$ of the 
Table 12. Typical costs and savings.

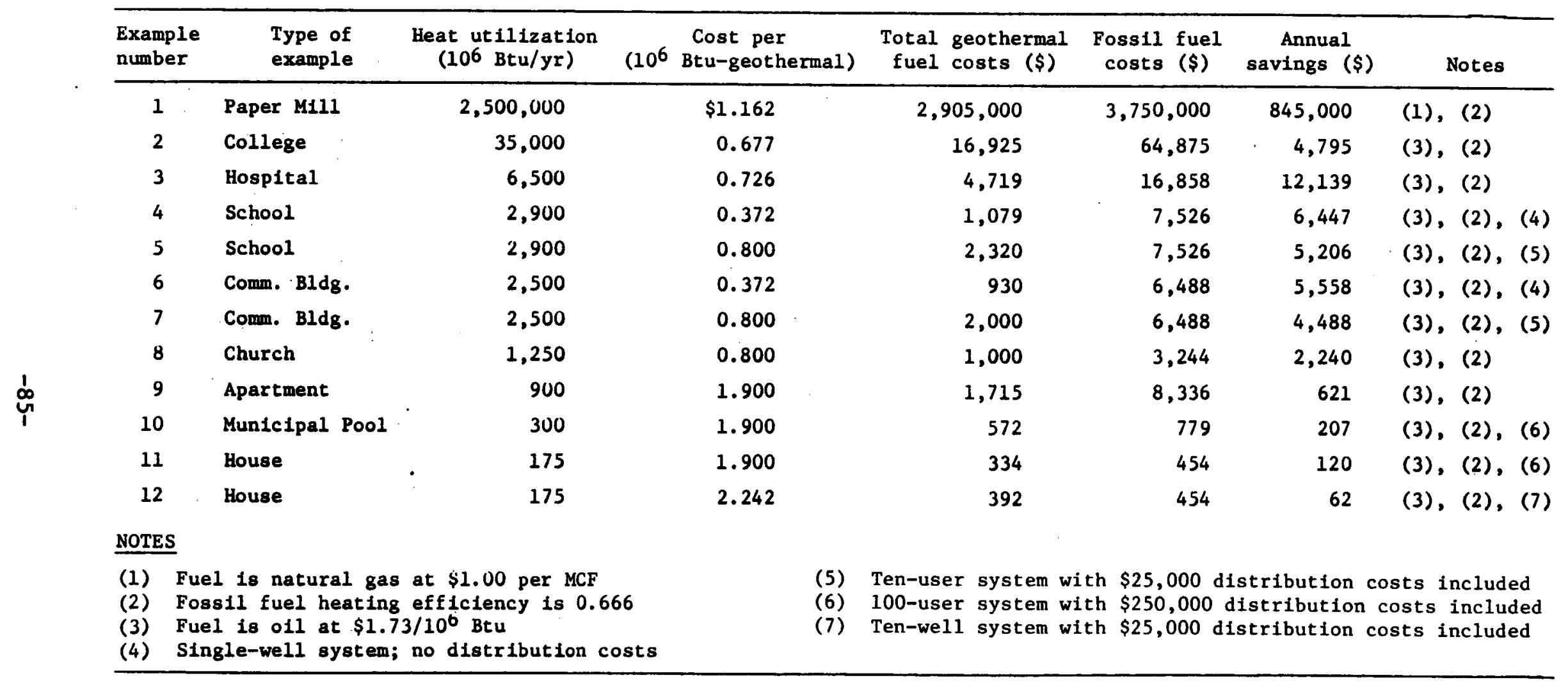


Table 13. Model geothermal town-site (population 100,000)

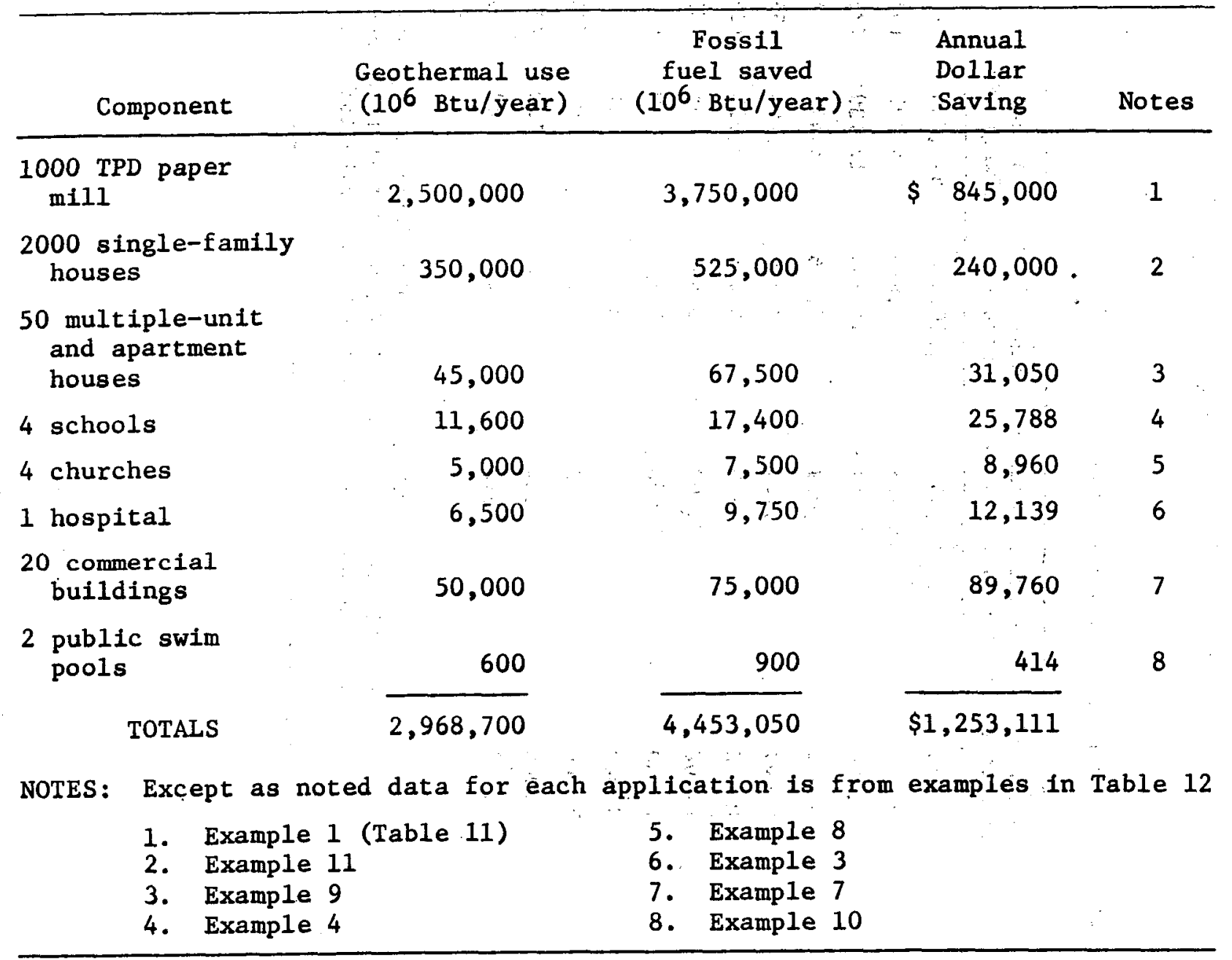

total construction cost), but they are quite reasonable for larger structures. For large users of higher temperature $\left(250^{\circ} \mathrm{F}\right)$ water, such as paper milis, the initial investment is very high but might be justified as an investment on fuel economy measures.

As low-temperature geothermal deposits adapted to these uses are expected to be the most common of the geothermal deposits, private and public planning should be almed to direct growth and industrialization so that these can be utilized and not removed from possible production by competing uses of the land, particularly near population centers in developing areas. 


\section{Regulatory Considerations}

INTRODUCTION

Concern over world-wide energy insufficiency has stimulated increasing interest in the development of geothermal resources. These resources may be broadly defined as any geologic occurrence from which geothermal energy may be economically extracted and applied to useful purposes. To be economically useful, a geothermal reservoir should possess the following characteristics:

a. It should operate at relatively high temperatures.

b. Be located at depths shallow enough that drilling costs are not prohibitive.

c. Have sufficient permeability in the rock medium to allow the heat transfer fluid (water, brine, steam) to flow at adequate rates.

d. Have sufficient recharge capability to allow prolonged production at economically acceptable rates.

Geothermal energy has generally been considered to be a natural resource and as such is subject to control and regulation by governmental bodies within whose jurisdiction it exists. The rules and regulations governing geothermal development have varied greatly between different governments and governmenta1 levels. In many instances these laws have been confusing, conflicting or even contradictory. It is the purpose of this section to present a general review of geothermal regulations from the standpoint of the philosophy behind them, the goals they are designed to achieve, and current regulatory practices. It is not our intent to discuss specific laws and their effect in any detail; such discussion more properly rests with the legal profession.

REGULATORY PHILOSOPHY

Aside from those laws intended to regulate the fair and orderly collection of taxes and revenues from the commercial exploitation of geothermal resources, the regulation of geothermal development is intended:

a. To prevent unsafe practices which might result in harm to individuals, the public, or to the physical environment.

b. To regulate and to protect property rights.

c. To regulate potential effects upon other natural resources, such as fresh water or minerals. 
d. To promote the economic, efficient and orderly development of this valuable resource.

To gain an understanding of regulatory needs and objectives, it is useful to review those items which might be of concern to the public and to governmental legislative and regulatory bodies.

\section{ENVIRONMENTAL IMPACTS}

The exploitation of géthermal resources may be roughly dividèd tnto developmental and production phases. The developmental phase consists of those activities required to define the resource. These include geo-tent logical, geophysical and geochemical exploration to find potentially. productive areas, followed by exploratory drilling and flow testing to quantitatively establish the production potential of specific wells and fields. Determination of the economic potential of a given geothermal field is followed by the production phase, during, which steam or hot water is produced and utilized.

Both phases may present a set of definable experimental problems, each subject. to regulatory controls under either general environmental or publichealth statutes: 1 For example, in the United States, such activities are regulated by the National Environmental Protection Act; or by sets of regulations specifically intended to regulate geothermal development, such as the Geothermal Steam Act of 19:70:

Environmental problems subject to regulatory control would include:

\subsection{Developmental Phase}

1.1. Aesthetic impact of the presence of drilling equipment.

1.2. Disruption of land surface by roads and by movement: of heavy equipment.

1.3 Noise of drilling operations

int. and possible blowouts.

1.4 Disposal and handling of drilling muds and slurries.

1.5 Air pollution resulting from possible blowouts.

1.6 Improper cleanup operations at abandoned we1ls.

1.7 Disturbance of local fauna.

1.8 Non-optimal land use, which involves the question of whether geothermal operations at a given site might preclude utilization of that area for more beneficial activities.

\subsection{Production Phase}

2.1 Waste disposal, including safe, proper management of condensates and brines, which might contain toxic and corrosive materials.

$2: 2$ Thermal pollution of waterways resulting from the direct

disposal of insufficient $1 y_{1}$ cooled fluids 
2.3 Subsidence. Land subsidence due to large scale withdrawal of underground fluids has been observed in certain geothermal areas, such as Wairakei, New Zealand. Differential subsidence could result in serious disruptions. For example, in areas utilizing gravity-flow irrigation systems, such as in the Imperial Valley of California, subsidence could pose a very serious problem.

2.4 Seismic Effects. Removal of geothermal fluid and pressurized reinjection of condensate or other spent fluids might possibly trigger seismic activity. Injection of fluids has caused microseismic events in areas near active fault zones.

2.5 Nolse. Exceedingly high noise levels can result from unrestricted flow of large volumes of pressurized steam.

2.6 Air pollution. Geothermal steam production inevitably results in the release of certain non-condensable gases through the atmosphere. These may include hydrogen sulfide, carbon dioxide, radon, methane and ammonia. Although observed release levels have generally been well within existing guidelines, concern has been expressed in this regard (State of California, 1974).

2.7 Ecological disruption. Introduction of almost any activity into a wilderness area may have an adverse effect on local flora and fauna.

2.8 Surface and aesthetic effects. Construction and other human activities associated with geothermal production in some circumstances can change the natural setting of a given 1and area in a detrimental manner by disfuguring the terrain with roads, pipelines, and equipment installation.

\section{REGULATORY PRACTICES (U.S.A.)}

Control of Geothermal Drilling and Production Operations

Most geothermal exploration and production involves the drilling of moderately deep wells. The potential exists for hazardous conditions surrounding the drilling rig, the drill site and the well bore itself. Geothermal wells share such potentials with both water wells and with oil and gas wells. Regulatory authorities have adapted the rules governing these activities to geothermal conditions. 
The physical dangers of hightemperature, high-pressure fluids and gases are perhaps more closely related to the conditions in ofl and gas weils and, indeed, geothermal drilling and completion rules are very often taken from oil well practicés (State of California, 1974; Anderson, D.N., 1973; Geothermal Resources Council, 1974). The geothermal requirements usually regulate such things as protection of fresh-water aquifers, well-abandonment procedures, provision of blowout prevention equipment when high pressures can reasonably be expected, production-well casing design, and construction of productionwellhead equipment. Examples of special rules for unique conditions are California's requirement for the following: (a) Heavy bracing of wellhead equipment to withstand the severe vibration associated with high flows of superheated water and steam; and

(b) steam-1ine sound mufflers, which control the very high noise levels associated with steam production (State of California, 1974). Oregon, concerned with possible contamination of fresh water aquifers, requires the vet: : wat aquer presence of a water-well driller on the drilling rig when aquifers are the drilling rig when aquifers are encountered (Anderson, D.N., 1973).

\section{Property Rights}

Because of its unusual nature, definition of a geothermal resource for the purpose of determining its ownership is often difficult. Whether geothermal energy should be considered as a mineral, fuel, water, or as unique in character (1egally, oui generis 1.e., "distinctive unto itself") has been the subject of much debate where individual ownership of such resources is legally recognized. In the United States, for example, such determinations have been made by the individual states (Table 14). (Anderson, D.N., 1973; Geothermal Resources Council, 1974 ; Aldiin, 1974). As one might expect, determination by individual states has produced wide varlations in definition of the resource. However, in this very variety of definitions, it is positible to appreciate the problem that jurisdictions have faced in defining a "geothermal resource". There is a fairly general acknowledgment that the resource is unique in character, but this acknowledgment includes a strong - sometimes overriding - concern for potential impact on other natural resources, particulariy fresh water supplies.

In those states where the resource is defined as unique, a legal problem arises." In many cases, land has been sold to which the mineral rights - oll, "gás, coal, etc. - have been retained by the original 
Table 14. Geothermal regulatory practices In the United States.

\begin{tabular}{|c|c|c|c|c|}
\hline State & $\begin{array}{l}\text { Legal character } \\
\text { of resource }\end{array}$ & Regulatory agencles & Regulations & Comments \\
\hline Mlaska & Unique & $\begin{array}{l}\text { Dept. of Matural Resources, } \\
\text { Div. of ofl \& Gas }\end{array}$ & $\begin{array}{l}\text { Geothermal Iw (1971). No } \\
\text { regulations at this cine. }\end{array}$ & $\begin{array}{l}\text { Used for' greenhouses, space } \\
\text { henting. }\end{array}$ \\
\hline Arizona & Unique & 011 and Gas Comisetion & $\begin{array}{l}\text { Ceothermal law (1972). Field regulations } \\
\text { to be eatablished as necessary. Leasing } \\
\text { of state lands by state Lands Department; } \\
\text { regulations due in near future. }\end{array}$ & $\begin{array}{l}\text { Arleona Power Authoritv may } \\
\text { purchase energy. Severance } \\
\text { tax enaeted. }\end{array}$ \\
\hline Callfornia & $\begin{array}{l}\text { Unique; water } \\
\text { posestbly by-product }\end{array}$ & $\begin{array}{l}\text { Dept. of Conservation, Div. } \\
\text { of oil and Gas. Environ- } \\
\text { wental regulations by } \\
\text { numerous state and local } \\
\text { agencies }\end{array}$ & $\begin{array}{l}\text { Ceothermal law (1965). Very comprehensive } \\
\text { operating regulat lons. Extensive environ- } \\
\text { mental requirements; county where a field } \\
\text { is locaced is the lead agency. Leasing } \\
\text { of state lands by state Lands comission. }\end{array}$ & $\begin{array}{l}\text { Operating fleld at the } \\
\text { Geysers, } 1 \text {. Callf. and } \\
\text { potential operations in } \\
\text { Imperial Valley and else- } \\
\text { where. Nonelectrical } \\
\text { applications in } \mathrm{ME} \text { Calif. }\end{array}$ \\
\hline Colorado & $\begin{array}{l}\text { Unique; state vater } \\
\text { law is also ef fective. }\end{array}$ & $\begin{array}{l}011 \text { and Gas Conservat ton } \\
\text { comisesion }\end{array}$ & $\begin{array}{l}\text { Geotherwal law (1974). Operating } \\
\text { regulations in preparation. Stace lands } \\
\text { leaged by state Board of Land Comisstoners. } \\
\text { Geotherwal rights ceparated from mineral } \\
\text { rights. }\end{array}$ & $\begin{array}{l}\text { Some exploration; no } \\
\text { operations at this time. }\end{array}$ \\
\hline Hawa 11 & $\begin{array}{l}\text { Mineral resource; } \\
\text { reserved to state. }\end{array}$ & $\begin{array}{l}\text { Dept. of Land and Katural } \\
\text { Resources. Environmental } \\
\text { regulat Lons by Dept. of } \\
\text { Planning and Econ. Develop- } \\
\text { ment, and county government. }\end{array}$ & $\begin{array}{l}\text { Geothermal law (1974); anendwents expected } \\
\text { in 1975. As atneral resource, geothermal } \\
\text { energy is reserved to the state. }\end{array}$ & $\begin{array}{l}\text { Exploratory operations near } \\
\text { R1lauea volcano, Island of } \\
\text { Hawail. }\end{array}$ \\
\hline Idaho & $\begin{array}{l}\text { Ualque; acknowledged } \\
\text { to affect ground water. }\end{array}$ & Dept. of Water Resources & $\begin{array}{l}\text { Geothermal law (1972). Operational } \\
\text { regulations include permits and regulation } \\
\text { of drilling practice. State Board of Land } \\
\text { Commissioners lease state lands. }\end{array}$ & $\begin{array}{l}\text { District heacing in Boise } \\
\text { area for many years. Raft } \\
\text { River exploratory project. }\end{array}$ \\
\hline Montana & $\begin{array}{l}\text { Unique; also under } \\
\text { water and mining law. }\end{array}$ & $\begin{array}{l}\text { Dept. of Natural Resources } \\
\text { and Conservation; State } \\
\text { Land Dept. }\end{array}$ & $\begin{array}{l}\text { Geothermal law (1974). Regulated as } \\
\text { appropriated ground water and under } \\
\text { Ut1lities Siting Act. No regulations } \\
\text { yet on leasing of state lands. }\end{array}$ & $\begin{array}{l}\text { Marysville exploratory } \\
\text { project permitted under } \\
\text { mining law. }\end{array}$ \\
\hline
\end{tabular}


Table 14. (cont)

\begin{tabular}{|c|c|c|c|c|}
\hline state & $\begin{array}{l}\text { Legal character } \\
\text { of resource }\end{array}$ & Regulatory agencies & Regulations & Comments \\
\hline Nevada & $\begin{array}{l}\text { Ground water } \\
\text { (appropriative use) }\end{array}$ & $\begin{array}{l}\text { Office of State Engineer, } \\
\text { Div. of Water Resources. }\end{array}$ & $\begin{array}{l}\text { Operates under Attorney General's opinion } \\
\text { (1965), which considers geothermal waters } \\
\text { to be ground water. Operations subject to } \\
\text { ground water appropriation permit and } \\
\text { drilling regulations. }\end{array}$ & $\begin{array}{l}\text { Extensive leasing and some } \\
\text { exploratory operations in } \\
\text { Northern Nevada. }\end{array}$ \\
\hline $\begin{array}{l}\text { New Mexico } \\
\therefore \quad \therefore .\end{array}$ & $\begin{array}{l}\text { Unique } \\
\vdots \\
\vdots\end{array}$ & $\begin{array}{l}\text { Oi1 Conservation Commission } \\
\therefore\end{array}$ & $\begin{array}{l}\text { Geothermad law (1973) Tentative regula- } \\
\text { tions formulated Permit required for } \\
\text { appropriative water use; drilling regula- } \\
\text { tions patterned on oil well rules. }\end{array}$ & $\cdots \quad \because \quad \therefore \quad \cdots \quad \cdots$ \\
\hline$\therefore \quad \therefore$ & $\begin{array}{l}\text { High temperature } \\
\left(+250^{\circ} \mathrm{F}\right) \text { resource } \\
\text { classed as unique; } \\
\text { below } 250^{\circ} \mathrm{F} \text {, consi- } \\
\text { dered as ground water. }\end{array}$ & $\begin{array}{l}\text { Dept. of Geology and Mineral } \\
\text { Industries; al so state } \\
\text { Engineer for low-temperature } \\
\text { resources } \\
\begin{array}{lll} & \end{array}\end{array}$ & $\begin{array}{l}\text { Geothermal law (1971) covers high temper- } \\
\text { ature source. Lower-temperature water } \\
\text { regulated by state engineer as well; } \\
\text { requires water-we11 driller on rig. } \\
\end{array}$ & $\begin{array}{l}\text { District heating in } \\
\text { klamath Falls area. } \\
\begin{array}{lll} \\
0\end{array}\end{array}$ \\
\hline Utah & $\begin{array}{c}\text { Water resource } \\
, \quad\end{array}$ & $\begin{array}{l}\text { Office of State Engineer, } \\
\text { Div. of Water Rights }\end{array}$ & $\begin{array}{l}\text { Geothermal law (1973) defined resource as } \\
\text { water subject to appropriative use. } \\
\text { Regulations in preparation. Divis of } \\
\text { State Lands leases state lands. Some } \\
\text { question about ownership of geothermal } \\
\text { rights on state lands. }\end{array}$ & 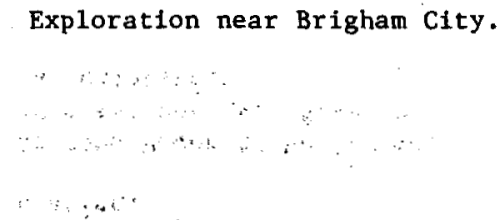 \\
\hline Washington & Unique & Dépt. of Natural Resources & $\begin{array}{l}\text { Geothermal láw (1974). Regulations not } \\
\text { yet completed. }\end{array}$ & $\therefore+\cdots \quad+\cdots+\infty \quad=$ \\
\hline Wyoming & $\begin{array}{l}\text { Water resource } \\
\text { (appropriative use) }\end{array}$ & State Engineer & Geothermal law (1973) & . \\
\hline
\end{tabular}

Note: Compiled in large part from D. N. Anderson (1973), Geothermal Resources Council (1974), Aidlin (1974). 
owner. If geothermal energy is not a mineral right, who owns it in such cases? Surface rights to much U.S. federal land have been sold to individuals, with the mineral rights being retained by the federal

government. Since the status of the resource is not clear, the Geothermal Steam Act of 1970 authorized, among other things, the filing of a suit in Federal court to establish the law about this case. The case is now in litigation, and the results should clarify the situation.

In a number of states, geothermal waters have been defined as ground water or, if recognized as unique, still have been subjected to water law. The concern exhibited for ground water resources centers in the semiarid American West, where fresh water has long been in short supply. In fact, Utah and Nevada, perhaps the most arid of the States, do not recognize geothermal water as being unique, but consider it as ground water. This leads to a problem if production of large quantities of geothermal water is contemplated. Western water law permits beneficial use of water under a "water right", which is controlled by the state. The laws generally recognize prior appropriation, where a priority is established by the seniority of the claim. Thus, a geothermal use of water would be controlled under the system of water claims, and if a conflict developed it might well be necessary to purchase pre-existing water rights. However, if the geothermal water were highly saline or mineralized and would thus not be useful as fresh water, as very frequently is the case, presumably there would be no conflict.

The reservoir characteristics of a geothermal fluid system have much to do with the economics of geothermal development. The reservoir may have a sufficient recharge/inflow of waters to replace the heated fluids removed and thus to support a high production rate. Or, there may be no recharge at all to the reservoir. In this case, when the heated fluid is removed, the deposit is simply exhausted. Far more common is the intermediate case, where there is some recharge, but it is not sufficient to maintain the reservoir in a steady state when large quantities of fluid are removed. In this case, there is some depletion of the geothermal resource, and thus of its property value.

If it is determined to be good public policy to produce a reservoir where some depletion occurs, a question arises as to compensation for depletion of the resource. Mining and oil law have long recognized depletion, and techniques have been 
devised to compensate the owrier for the destruction of his capital. Typicaliy, this is done by:a depletion allowance on taxes, al though other ... devices süch as tax forgiveness and . direct subsidy have been used. $\mathrm{Tn}$ the United States, depletion allowances for hydrocarbon resources have recently (1975) been almost totally eliminated. This elimination will undoubtedly. influence the legal treatment of geothermal resources.

\section{Confilct with Regulation of Other Resources}

A number of jurisdictions are concerned with any potential impact of the withdrawal of geothermal waters upon fresh water supplies and have made rules to control geothermal uses. There is also a potential conflict with mineral rights. Many geothermal waters are highly mineralized. In perhaps the most interesting case, the highly saline waters encountered in the Salton Sea area of California contain high levels of such minerals as manganese, copper, and silver (Helgesen, 1968; Elders, 1972). If it is considered desirable to extract these minerals, then there is a clear possibility of conflict with mineral extraction law.
INTERNATIONAL :REGULATORY PRACTICES

\section{Introduction}

Regulation of geothermal resources is in its early stages, and many problems remain to be resolved. Information is available on regulatory systems from Canada, Iceland, Itầy, New Zealand, the Phillippines, and the United States. Table 14 shows details of these regulatory practices for the United States. In the United states, much of the regulatory authority is vested in the individual states. These variations are most instructive in displaying the range of legal and technical problems which concern the regulators. A discussion of the approach to regulatory practices in other countries follows:

\section{Representative Regulatory Practices} Canada- According to the wording of Bill No. 77, the Geothermal Resources Act of 1973 (Second: Session), In the Legislative Assembly of the Province of British Columbia; $a$ geothermal resource is defined as:

"the natural underground reservoirs of heat that may be exploited, developed, or used for the production of heat energy, including, without limiting the generality of the foregoing, any minerals that may be obtained by means of a geothermal resource or by a 
natural or artificial injection of fluid, brine, gas, or steam in any form; but does not include petroleum resources, or water that is less than two hundred and fifty degrees Fahrenheit measured at its lowest location underground". Presumably, this definition implies a unique resource.

No regulation has been necessary to date since no exploration or development has taken place, except for a very small effort by British Columbia Hydro, which is a Provincial Utility (Jessop, 1975). Responsibility lies with the Provinces within their boundaries and with the federal government for the Territories and offshore areas.

\section{Iceland- Ownership and use of} geothermal resources in Iceland is generally vested in the owner of the land (Torfason, 1975). These resources are regulated under the Energy Act of 1968. Some of the provisions of this Act are that geothermal resources may not be separated from the land without spectfic State approval, that local municipalities or the State have preemptive right-of-purchase when a property comes up for sale, and that the State may expropriate geothermal resources for public use, subject to appropriate compensation of the owner. The Act also provides that when a geothermal fleld crosses property lines, the case shall be settled by proration established by expert appraisal.

At the present time, a proposal in the Icelandic legislature, the Althing, states that the State should assume ownership of all hightemperature geothermal fields temperatures over $200^{\circ} \mathrm{C}$, at depths down to 1000 meters. This proposal has been under discussion for a long time; meanwhile, for all practical purposes the main point of the proposed legislation has been achieved. Through ownership of the land, the State and local municipalities have control of many of the known hightemperature geothermal fields.

The national Energy Authority has been as established as the State agency to carry out the national interest in the exploration of geothermal resources and the supervision of their conservation and development. The Authority also assists the Government in policymaking and planning for geothermal matters. The State has the right to explore for geothermal resources in any location; the National Energy Authority operates a drilling division to carry out such exploration. 
There are 1imitations on the utilization of geothermal resources for electrical power plants of over $2000 \mathrm{~kW}$ capacity, and for municipal heating. A concession from the State is necessary to construct and operate an electrical power plant. The granting of such concessions is reserved to the Althing, with special legislation required for each case. In practice, electrical power development by public agencies has been favored. Through the years, the production and distribution of electrical power has been handled by utility corporations owned by the State and/or major municipalities. Production of electrical power for heavy Industry has been undertaken by the largest of these corporations, Landvirkjun (the National Energy Company).

Development of geothermal power for other purposes has not been as extensively regulated. Hortlcultural use is already widespread. In a recent case where a major supply of geothermal steam for use in a diatomaceous earth plant was required, the steam was supplied by an independent division of the National Energy Authority.

Italy- Geothermal resources, both steam and thermal waters, are considered minerals under legislation of
1927 (Barbier, 1975). Treatment of the two kinds of resource is somewhat different. Geothermal steam is considered a mineral of national interest and therefore is regulated by the national government. The Ministry of Industry controls leasing grants. Development of geothermal steam for electrical power production is granted exclusively to NEEA (National Electrical Energy Agency). Other parties may be granted leases for other purposes. Thermal waters are regulated by regional authorities, who grant leases for utilization and regulate operations.

\section{New Zealand- In New Zealand,} (Dench, 1975) jurisdiction over geothermal resources is vested in the national goverment under the Geothermal Steam Act. Geothermal energy is defined as belng derived from the earth's natural heat at a temperature greater than $70^{\circ} \mathrm{C}$. Development by both government agencles and private individuals is allowed. The Ministry of Works and Development controls development and utilization of geothermal resources. Heat for domestic use drawn from wells having a depth of less than $61 \mathrm{~m}$ ( $200 \mathrm{feet}$ ) is excluded from the licensing requirements; the Intent is to exempt minor users from the controls of the national law. Most such use is in 
the town of Rotorua, which has muntcipal laws covering geothermal we11s.

The Ministry of Works and Development may issue an exploration permit to any competent person to engage in geothermal exploration and drilling. If the search is successful, ut 1lization of the geothermal energy is a separate issue, subject to more comprehensive provisions incorporated in a license to use the energy. Additionally, the use of geothermal waters is dependent upon permission from regional water boards, which are espectally concerned with the chemical quality of water and the heat contained in it in relation to the capability of natural waterways to absorb these effluents.

The license includes a rental charge for the use of geothermal heat. At present, the rate is quite low, 1.e., 0.3 U.S. cents per thousand millions Btu's (terajoules) used. This fee was set in 1966 in order to encourage the use of geothermal energy rather than oil, electricity, or coal. Since that time, energy costs have increased. generally and the rate is currently being reconsidered. .

Compensation is payable to the owner of the surface rights whose property values have depreciated; this does not include payment for the value of the energy that has been extracted.

The Geothermal Steam Act also regulates the construction of deep geothermal wells, principally being concerned with surface blowouts and uncontrolled wells. Approval of the casing-string design and the cementing program are required before a permit is issued. Drilling records are maintained and well samples kept; these may be inspected by geologists and other scientists. Safety regulations governing surface operations are part of the general industrial safety law.

Environmental issues are covered under the Town and Country Planning Act, and by the requirement that proposals for tax-funded work be reviewed by an independent commission; in both cases, there is opportunity for public comment. The Clean Air Act and the Water and Soil Conservation Act also cover specific aspects of the environment.

The Philippines- In the Philippines, (Alcarez, 1975) geothermal energy is considered a unique resource. Repub11 c Act No. 5092 of 1967 defines geothermal energy as energy derived from the earth or produced within it by natural phenomena. All steam, hot water and their mixtures are included. 
The Director of Mines is charged with carrying out the provisions of the Act. The Act is separate and distinct from similar acts covering petroleum and minerals, also under the jurisdication of the Director of Mines.

\section{United States- Except for Federal} operations: on federally-owned land, the individual states establish : : regulations for development of geothermal resources. Only the State of California has had extensive exploratory drilling and large-scale production of geothermal heat. As a natural result, it is the only: jurisdiction which has really detailed regulations : Federal regulations are primarily concerned with operation on federa1ly-owned: land or by federal agencles; however, nationwide environmental controls have been established in recent years and their enforcement has been mandated upon the states.

Federal activities are regulated under the Geothermal Steam Act of 1970, and the National Environmental Protection Act (NEPA). The federal government has exclusive control over operations carried out on federally owned iands. These activities are not subject to local controls, though usually these are honored in a spirit of cooperation. The Geothermal Steam
Act of 1970 defined the geothermal resource, made provision for judicial determination of the ownership of geothermal rights on lands sold by the Federal government where the mineral rights were retalned, and gave authority to establish procedures for leasing and development of Federally-owned lands. A rather complex procédure for granting leases has been developed; basic responsibilIty for administration rests with the U.S. Geological Survey (Stone, 1974). Under the National Environmental Prótection Act, any major Federal action must be preceded by the issuance of an Environmental Impact Statement (EIS). "This document; which Is intended to compel some degree of technological forecasting, is required to predict the effects of the proposed action on a number of things, including air and water pollution, nolse, aesthetics, population changes, fish and wildife, and histortcal sites. These statements tend to be encyciopedic and represent a major effort. Among kinds of Federal actions for which such statements are required is leasing of large tracts of land for exploration or development.

Federal pollution-control standard must be met by all activities, both public and private. These standards are concerned with alr and water pollution, and excessive noise. 
Enforcement of the standards is

mandated upon the states.

The American states have a variety of approaches to the regulatory problems of geothermal activity, and available information about them is tabulated in Table 14. As mentioned earlier, California was the first to establish detailed regulations, and many of the other states have modeled their approach more or less after the California example.

Most of the states define the geothermal resource as unique, with a recognition of the potential impact on ground water resources. Two states, Nevada and Utah, consider geothermal waters to be a water resource and not unique. Hawail, in recent legislation, defined any geothermal energy resource as a mineral (Kamins, 1974) in order to reserve it to the state; public development is intended. All the states where actual geothermal drilling has taken place have regulations on drilling and completion practices, adapted from oll well or water well rules. Such things as protection of fresh water aquifers, abandonment practices, and production operations are matters of concern.

Environmental, laws have generated a new and of ten complex set of regulations. The situation in California is an excellent example. There are extensive environmental requirements, which are probably more a function of the advanced state of development of geothermal energy and the newness of environmental laws in the state than any special tendency of the state government towards regulatory zeal. Controls on drilling and production are vested in the State Conservation Department's Division of $0 i 1$ and Gas. There is a State Geothermal Officer and a staff specializing in the geothermal area. Recently passed state laws give authority over various environmental aspects of geothermal development of a number of agencies. Table 15 is a list of such agencies for California with some jurisdiction over geothermal operations, indicating their particular responsibilities.

California has an Environmental Quality Act. The state courts have held that any significant action requiring a license, public or private, must be preceded by an Environmental Impact Report (EIR). ThIs report is similar to but not identical with the Federal Environmental Impact Statement, which is required only on Federal lands. In addition, an environmental statement may be required by the county. As a result, a potential developer may face the preparation of as many as three extensive and dissimilar environmental reports before commencing any activity. 
Table 15. California regulatory agencles and their responsibilities relative to development of geothermal resources

\begin{tabular}{|c|c|}
\hline Agency & Responstbility \\
\hline $\begin{array}{l}\text { Conservation Dept., Div. of 0il } \\
\text { and Gas }\end{array}$ & $\begin{array}{l}\text { Drilling, production and abandonment } \\
\text { of geothermal wells }\end{array}$ \\
\hline Regional Water Quality Control Board & $\begin{array}{l}\text { Federally mandated water pollution } \\
\text { controls }\end{array}$ \\
\hline $\begin{array}{l}\text { Regional Alr Quality Control Board } \\
\text { (There is one Air and Water } \\
\text { Quality Control Board for each of } \\
\text { a number of designated geographic } \\
\text { regions of the state) }\end{array}$ & $\begin{array}{l}\text { Federally mandated air pollution } \\
\text { controls } \\
\end{array}$ \\
\hline State Air Resources Board & Air pollution \\
\hline Dept. of Fish and Game & Fish and wildlife \\
\hline State Resources Board & Environmental impact report \\
\hline County in which resource is located & $\begin{array}{l}\text { Controls a11 development in county. } \\
\text { May impose environmental require- }\end{array}$ \\
\hline$\therefore \quad:$ & $\begin{array}{l}\text { ments. Designated as lead agency } \\
\text { in meeting environmental } \\
\text { requirements. }\end{array}$ \\
\hline
\end{tabular}

In practice, getting clearance from the involved agencies has been extremely time-consuming, with lead times of over a year for field development wells in The Geysers field of Northern California (Anderson, D.N., 1974b). A first response to the problem has been the designation of the county in which the development is located as the lead agency responsible for the accomplishment of the regulatory process. This has improved the situation, but the process is still slow. The entire process is shown graphically in Fig. 22, a flow chart prepared by D.N. Anderson, State Geothermal officer of California.
PROBLEMS

Considering its potential availability, low cost, and low environmental degradation relative to alternate energy sources, geothermal energy could make a signiflcant contribution to the alleviation of energy shortages. For this reason, it would seem reasonable that the development of this resource should be allowed to proceed as expeditiously as possible. Yet there are several factors limpeding this development. Many of the problems are technological In nature and amenable to solution by scientific and engineering research. 


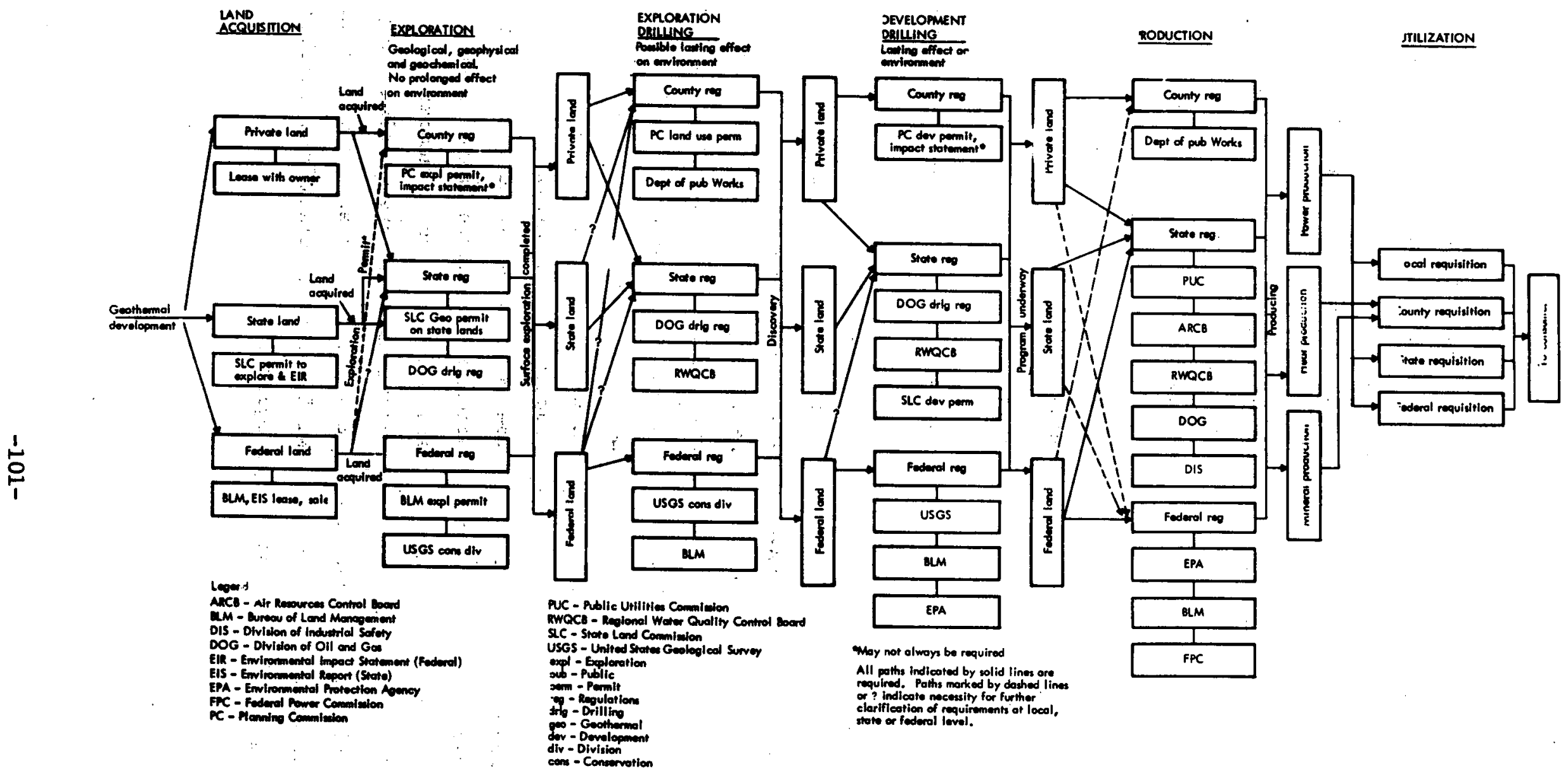

Fig. 22. Flow chart of critical path in geothermal resource development in California, USA. (Anderson, 1975). The path to utilization of geothermal resources is awkward to traverse owing to the maze of regulatory agencies. A company developing a resource situated on a combination of private, state and federal land would have to interact with all groups listed on the figure. 
Solving these problems will, in turn, contribute to minimizing difficulties in financing projects by reducing the levels of risk and uncertainty.

Certain regulatory practices also hinder the orderly and expeditious development of geothermal energy. The developer of a potential geothermal area is often faced with the need for compliance with a series of laws and regulations which are ponderous, confusing and sometimes in conflict with each other. We have discussed the regulations operative in the state in Californta where, for example, two substantial environmental statements may have to be prepared. Thus, assuring compliance with regulations can, in itself, absorb a substantial amount of time and resources which a developer might otherwise be able to devote to the actual development and production of geothermal energy.

Another impediment facing the geothermal developer is the need for compliance with often unreasonable interpretations of environmental regulations. Clearly, the intent of environmental legislation is to prevent serious degradation of the environment by developments. It would seem reasonable to suit the degree of control to the seriousness of the environmental hazard to be controlled. The need for dispassionate and quantitative cost-benefit analyses as a tool for decisionmaking is apparent. Such analyses would enable balancing of economic and social imperatives with environmental considerations.

\section{FUTURE NEEDS}

To proceed with the development of geothermal energy in an orderly and expeditious manner, an urgent objective is clarifying the confusion and inconsistencies in current regulatory practice. One study in this direction is in progress at the Universtty of California School of Law (at Berkeley)... Headed by S. Sato, this group is looking into the legal problems of geothermal resources. The work is sponsored by the National Science Foundation (Sato, 1974), and a report about a number of legal questions is in preparation. Hopefully, this work and similar studies will assist In clarifying geothermal regulations. 


\section{Problems and Possibilities}

INTRODUCTION

The purposes of this section are (1) to state the problems that appear to affect the continued development of nonelectrical applications and (2) to list the recommendations agreed upon by the Subcomnittee. Also, it should be noted that while the statement of problems represents the Editor's own viewpoint, the recommendations in the chapter represent the concensus of the Subcommittee. Appendix A (Minutes of the CCMS Nonelectrical P1lot Study Meeting, Paris, France, June 25, 1975) gives a more complete plcture of the views and recommendations of others.

PROBLEMS

There are four kinds of problems affecting the use of geothermal resources for nonelectrical applications. These are, in order of importance, (1) cultural, (2) economic, (3) technical, and (4) institutional/ legal.

Cultural Problems

The cultural problem may be termed "cultural inertia". Energy demands throughout the industrial parts of the world have been satisfied largely by oil, gas, coal, and nuclear fuels.
These fuels have been dependable and have been available at reasonable prices. Everyone is well aware, however, of the changes that have occurred in the energy markets of the world in the last few years. Geothermal resources used for nonelectrical applications can satisfy some of the demand for energy but the transition necessary to realize this potential (and that of other "exotic" energy forms) must overcome a considerable amount of inertia. The concerted effort by the French to overcome this inertia (BRGM, 1975) should be noted. Geothermal energy is new to most of the world, and its "place" has yet to be established.

\section{Economic Problems}

Economics is a concern of all who have considered investment in a nonelectrical geothermal project. Generally speaking, to date, the economics of nonelectrical applications have been good (e.g., Iceland, New Zealand). Although some projections for the future also generally appear good (see the section on Economics in this report), the group which met in Paris was uncertain on this point, especially when the question of the economics of alternative energy sources was raised. 
There is clearly a need to standardize the methods of economic analysis. (A proposal for this kind of work was presented to the group by C.H. Bloomster of Battelle Northwest Laboratories, Richland, Washington, U.S.A. See Appendix 1). Not al1 analysts, for instance, include exploration costs in the economics of nonelectrical applications. Also, some carry out discounted cash-flow analyses and others focus on the assigned interest rate of the unpaid balance of a loan and its comparison with current interest in order to judge the economics of an appication. There is thus a need for standardization of analyses, and it was recommended that this be undertaken in the next phase of the project.

\section{Technical Problems}

There are, perhaps, three outstanding technical problems associated with nonelectrical applications of geothermal resources. Heat exchangers capable to handling "aggressive" fluids need to be more fully evaluated. Direct-contact exchangers have been reviewed only in Iceland, for instance (Arnorsson, et a $q$, 1975). . The role of heat pumps has not been defined, although the French are working on this problem (Duminil, 1975). Finally, a majox problem is definition of the resource. More

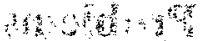

could be done in analyzing the strategies of resource definition in order to plan an investment to exploit that resource." The concept of a "resource Indemificàtion program" was not mentioned in any of the official nonelectrical subcomittee : : meetings but it is an intriguing idea that sums up the essence of the problem of resource definition.

\section{Institutional/Legal Problems}

- Institutional and legal questions do not appear to be holding up nonelectrical applications of geothermál resources at this time. Indeed, there are problems, e.g., pre-emptive use for balneological purposes, uncertain jurisdiction and status of low temperature water, but these do not seem to be as significant as cultural inertia and economics. Positive moves to aid the development of nonelectrical applications such as tax incentive programs would be welcome, nevertheless. sitios.

FUTURE POSSIBILITIES

At the Paris meeting, guidance for future work on the Project included the following First, there was a strong expression of interest (as already noted) in more clearly understanding the economics of nonelectrical applications. The 
consensus of the group was that the next phase of the Project should definitely address this topic. Second, there was no call for a hardware-centered activity during the next phase of the Project. Third, by way of offering guidance to future efforts, the group endorsed a general policy statement, with the thought that this statement would ultimately be accepted and endorsed by the governments represented by those present. This statement can be summarized as follows:

General Recommendations - CCMS Geothermal Pilot Study

1. Support efforts to inventory national geothermal resources suitable for nonelectrical applications.

2. Encourage demonstration of both simple and advanced applications under monitored conditions.

3. Support research and development of new applications.

4. Encourage government financlal support of demonstrations.
5. Encourage interfacing of electrical and nonelectrical applications.

6. Advocate reasonable changes in the law favorable to development of nonelectrical uses.

7. Encourage free exchange of information.

8. Seek maximum effective use of internationally available technology through joint projects.

FURTHER PROJECT PHASES

Publication of this report concludes the first phase of the CCMS Geothermal Pilot Study Nonelectrical Applications Project. The next phase of this Project will be led by the government of France. French workers have shown a great deal of interest in nonelectrical uses of geothermal resources (de Marsily and Delhome, 1975). All who have an interest in this important topic wish them success during their tenure. 
Acknowledgments

$\because$ Thanks are due to those who carried out speclal projects for

Bressee, Mr.F.S.M. Hodso11, Dr. Lawrence Livermore Laboratory, and to the authors of sections of the various appendixes. These include

A. Alcarez, E. Barbler, L.L. Boersma, G.C: Culver, C.D. Hònburg, J.W. Lund, o.J. Morin, W.B. StIlwell, L.S. Svanevik, and E. Tan. Also, a special note of appreciation is due Professor Gunnar Bodvarsson, Dr. James C.

William E. Ogle, and Professor Ezio Tongiorg1, all of whom did a great deal to concelve and guide the work on which this report is based.

Finally, special thanks are due to C.A. Be11, V.D. Caswell, I.M. Morvay and K.M. Young who showed a great deal of patience in the face of a very difficult research, editing and production task. 


\section{References}

J. W. Aldlin, "Development of Geothermal Laws and Regulations," in Preliminary Study Guide, California Dept. of Oil and Gas/Geothermal Resources Council, Short Course No. 2, May 1974 (Geothermal Resources Council, P. 0. Box 1033, Davis, CA, 95616) (1974).

A. Alcarez, National Power Corporation, Republic of the Philippines, Private Communication (1975).

J. H. Altseimer, Geothermal Well Technology and Potential Applications of Subterrene Devices, - A Status Review, Los Alamos Scientific Laboratory, Rept. LA-5689-MS (1974).

H. C. H. Armstead, "Geothermal Heat Costs," Energy International (Brussels, 1969) p. 28.

D. N. Anderson, "Geothermal laws and regulations in the Western United States," in Calif. Dept. of 011 and Gas/Geothermal Resources Council, Short Course, (P. 0. Box 1033, Davis, CA, 95616) (1973).

D. N. Anderson, "Flow chart of critical path in geothermal exploration," in Proceedings, National Conference on Geothermal Energy, (Univ. of California, Riverside; National Sclence Foundation/RANN, 1973), pp 141-143.

J. H. Anderson, "The vapor-turbine cycle for geothermal power generation," in P. Kruger and C. Otte, eds., Geothermal Energy (Stanford, Stanford University Press, Palo Alto, 1973) pp 163-175.

S. Arnorsson, K. Ragnars, S. Benediktsson, G. Glslason, S. Björnsson, K. Grönvold, and B. Lindal, "Exploitation of saline high temperature water for space heating," in Proc. Second United Nationals Symposium on the Development and Use of Geotherma1 Resources, (San Francisco, California, Paper No. VIII-1) (1975) (In preparation)

A. L. Austin, S. D. Winter, U. S. Energy. Flow Charts for 1950, 1960, 1970, 1980, 1985, and 1990, Lawrence Livermore Laboratory, Rept. UCRL-51487 (1973).

C. J. Banwe11, "Geophysical Techniques in Geothermal Exploration," in Proc. U. N. Conf. on New Sources of Energy, Rome, 1961 (United Nations, New York, 1964), Part 1 (1970) pp 32-57.

C. J. Banwe11, "Geophysical Methods In Geothermal Exploration," in Geothermal Energy: Review of Research and Development (UNESCO, Paris, 1973) pp 4148.

E. Barbier, Italian National Research Council; PIsa, private communfcation (1975).

J. Barnea, "Multipurpose exploration and development of geothermal resources," Natural Resources Forum 1, 1 (United Nations, New York, 1971) p. 55-58. 
F. Begemann, "The tritium content of hot springs in some geothermal areas," in E. Tongiorgi, ed., Nuclear Geology in Geothermal Areas, (Lab. Geologia Nucleare, Pisa, 1963), pp 55-70.

L. Belteky, "Development and Utilization of Thermal Waters in Hungary," Geothermics, 1, 3 (1972) pp 103-112.

G. Bodvarsson, "Oxygen in Thermal Waters and Corrosions of Heating Systems," J. Eng. Assn. Iceland, 35, 6 (1950) pp 70-72.

G. Bodvarsson, "Laugarhitun og rafhitun," in Geothermal and Electrical Heating, Timarit Verkfraed. Islands, 39, 1. (In Icelandic) (1954).

G. Bodvarsson, "Utilization of Geothermal Energy for heating purposes and combined schemes involving power generation, heating and/or by-products," in Proc. U. N. Conf. on Néw Sources of Energy, Rome, 1961 (United Nations, New York, 1964), Paper GR/5(G).

G. Bodvarsson and J. Zoëga, "Production and distribution of Natural Heat for Domestic and Industrial Heating in Iceland," in Proc. U. N. Conf. on New Sources of Energy, Rome, 1961, (United Nations, New York, 1964), Vo1. 3, Paper G/37.

G. Bodvarsson and S. S. Einarsson, "Geothermal energy for domestic and industrial heating," in Proc. Conf. of Icelandic Engineers, Reykjavik, 1964 (Reykjavik, Verkfraedingafelag Islands, 1964). (In Icelandic)

G. Bodvarsson and G. Palmason, "Exploration of subsurface temperature in Iceland," in Proc. U. N. Conf. on New Sources of Energy, vo1 2, Paper G/24, Rome 1961, (United Nations, New, York, 1964).

G. Bodvarsson, "Thermal problems in the siting of reinjection wells," Geothermics, 1, 2 (1972) pp 63-66.

G. Bodvarsson, "Dikes as fluid conductors in the extraction of terrestial heat," Geotherma1 Energy 2, 9 (1974) pp 42-50.

T. Boldizsar, "Geothermal energy production from porous sediments in Hungary," Symposium on the Development and Utilization of Geothermal Resources, PIsa, Geothermics, Special Issue No. 2, vo1. 2, part 1 (1970) pp 99-109.

T. Boldizsar, "Geothermal energy use in Hungary," in Proc. International Conf. on Geothermal. Energy for Industry Agricultural and Commercial-Residential Uses, 1974 (Oregon Institute of Technology, Klamath Falls, Oregon, U.S.A., 1974).

BRGM, "La Geothermie en France," Bulletin du Bureau de Recherches Geologiques et Minieres, Deuxieme Series, Section 2, (I. Delbois, Ed., 74, rue de la Federation, 75739, Paris, France 1975).

C. F. Budd, Jr., "Steam production at the Geysers Geothermal Field," in P. Kruger and C. Otte, Eds., Geothermal Energy (Stanford University Press, LC 72-85700, 1973) pp 129-144. 
W. Burrows, "Geothermal energy resources for heating and associated applications in Rotorua and surrounding areas," UN Symposium on Development and Utilization of Geothermal Resources, Pisa (Geothermics, Special Issue No. 2, vol 2, part 2, paper X/3, 1970) pp 1662-1669.

W. Burrows, "Utilization of Geothermal Energy in Rotorua, New Zealand," in Proc. Internat. Conf. on Geothermal Energy for Industry, Agriculture, and Commercial-Residential Uses (Oregon Institute of Technology, Klamath Falls, Oregon, U.S.A., 1974).

State of California, Dept. of Conservation, Div. of 0il and Gas, Proposed Geothermal Regulations, Final Draft (Revision of Public Resources Code, Chapter 4, Div. 3, Subchapter 4, "Geothermal Operations," 1974).

W. L. Cooke, "Some methods of dealing with low enthalpy water in the Rotorua area of New Zealand," UN Symposium on the Development \& Utilization of Geothermal Resources, Pisa (Geothermics, Special Issue 2, vol. 2, part 2, 1970) pp 1600-1675.

H. Craig, "The isotopic geochemistry of water and carbon in geothermal areas," in E. Tongiorg1, Ed., Nuclear geology on geothermal areas (Lab. Geologia Nucleare, Pisa, 1973) pp 17-53.

J. Cromling, "How geothermal wells are drilled and completed," World 0i1, 177, 7, 1973) pp 57-63.

G. Culver, J. W. Lund, and L. Svanevik, Klamath Falls Hot Water Wel1 Study, Lawrence Livermore Laboratory, Rept. UCRL-13614 (1974).

D. Dedkova, J. Halousek, B. Kercmar, and K. Prihoda, "Geothermal prospecting in shallow holes and its limitations," $U$. $N$. Symposium on the Development and Utilization of Geothermal Resources, Pisa (Geothermics, Special Issue, 2, vol. 2, part 2, 1970) pp 1244-1250.

G. De Donato, "Airborne thermal infrared scanning used for geothermal energy exploration," Geothermal Energy, 2, 4; 1974) p. 56.

G. De Marsily and M. Delhomme, Journees sur L'Emploi de la Geothermie dans le Chauffage Domestique et Industriel, (Centre d'Informatique Geologique, Ecole des Mines des Paris, 35 rue Saint-Honoré, 77305-Fontainbleu, 1975).

N. D. Dench, "Reconditioning of steam bores at Kawerau," N. Z. Engineering, 17, 353 (1962).

N. D. Dench, "The Law and Geothermal Development in New Zealand," in Proc. U. N. Conf. on the Development and Uses of Geothermal Energy, (San Francisco, Ca11fornia, 1975). (In preparation)

I. G. Donaldson, "The simulation of geothermal systems with a simple convective mode1," U. N. Symposium on the Development and Utilization of Geothermal Resources, No. 22, Pisa (Geothermics, Special Issue No. 2, vo1. 2, part 1, 1970) pp 649-654. 
G. Dragone and 0. Rume, "Pilot greenhouse for the utilization of lowtemperature waters, United Nations Symposium on the Development and Utilization of Geothermal Resources, Pisa (Geothermics, Special Issue No. 2, vol 2, part 1, 1970) pp 918-920.

DSS Engineers, Inc, Geothermal Resource Utilization-Paper and Cane Sugar Industries, Lawrence Livermore Laboratory, Rept, UCRL-13633 (1975).

M. Duminil, "Considerations sur les Cycles Thermodynamics des Pompes de Chaleur a Compression," in Journees sur L'emploi de la Geothermie dans la Chauffage Domestique et Industriel, M. de Marsily and M. Delhomme, Eds., (Ecole des Mines de Paris, Fontainbleau, France, 19.75).

S. S. Einarsson, "Geothermal District Heating," in Geothermal Energy: Review of Research and Development, (United Nations Education, Scientific and Cultural Office (UNESCO), Paris, 1973) pp. 123-134.

W. A. Elders, R. W. Rex, T. Meridan, P. T. Robinson and S. Biehler, "Crusta1 Spreading in Southern California," Science, 178 (1972) pp 15-24.

G. Facca, "The structure and behavior of geothermal fields," in Geothermal Energy: Review of Research and Development, (UNESCO, Paris, 1973) pp 61-72.

J. P. Finney, "Design and Operation of the Geysers Power Piant", in P. Kruger and C. Otte, Eds. Geothermal Energy, (Stanford University Press, LC $72-85700,1973)$.

R. O.. Fournier and A. H. Truesde11, "An Empirical Na-K-Ca Geothermometer for Natural Waters", Geochim.. cosmochim. Acta, 37 (1973) pp 1255-1275.

C. Gatlin, Petroleum Engineering, (Prentice-Ha11, Englewood Cliff, N.J,, 1960).

Geothermal Resources Council, Spectal, Short Course No.. 2, "Geothermal Regulations, Preliminary Study Guides", (Calif. Dept. of Oil and Gas/ Geothermal Resources Council, Davis, CA, 1974).

J. Guiza, Commission Federal de Electricidad, Mexico, Personal Communication (1974).

H: C. Helgeson, "Geologic and Thermodynamic Characteristics of the Salton Sea Geothermal System", Am. Jour. Science, 266, (1968) pp 129-166.

S. Hermannsson, "Corrosion of Metals and the Forming of Protective Coating on the Inside of Pipes in the Thermal Water Used by the Reykjavik Municipa1 District Heating Service, United Nations Symposium on the Development and Utilization of Geothermal Resources, Pisa (Geothermics, Specia1 Issue No : 2, vol. 2, part 2 , 197.0) pp 1602-1612."

J. Head, "Geothermal Energy for Greenhouse Heating", Ore Bin 32, 9. (1970) pp 182-183. 
M. P. Hochstein and D. J. Dickinson, "Infrared remote sensing of thermal ground in the Taupo region, New Zealand", United Nations Symposium on the Development and Utilization of Geothermal Resources, Pisa (Geothermics, Special Issue No. 2, vol. 2, part 1, 1970) pp 420-423.

D. T. Hodder, "Application of remote sensing to geothermal prospecting", United Nations Symposium on the Development and Utilization of Geothermal Resources, Pisa (Geothermics, Special Issue No. 2, vol. 2, part 1, 1970) pp 368-380.

B. A. Holt, S. L. Hutchinson and D. S. Cortez, "Geothermal Power Generation Using the Binary Cycle", Geothermal Energy, August 1973, pp 45-57.

R. James, G. D. McDowell and M. D. Allen, "Flow of steam-water mixtures through a 12-inch Diameter Pipeline, Test Results", United Nations Symposium on the Development and Utilization of Geothermal Resources, Pisa (Geothermics, Special Issue No. 2, vol. 2, part 2, 1970) pp 1581-1587.

A. M. Jessop, Earth Physics Branch, Seismology Division, Ottowa, Canada, Private Communication (1974).

P. Jones, "Geothermal Resources of the Northern Gulf of Mexico Basin", United Nations Symposium on the Jevelopment and Utilization of Geotherma1 Resources, Pisa (Geothermics, Special Issue No. 2, vol. 2, part 1, 1970) pp 14-26.

R. M. Kamins, "Legal and Public Policy Setting for Geothermal Resource Development in Hawaif", in Proc. Conf. on Research for the Development of Geothermal Energy Resources, September 23-25, 1974, (National Science Foundation, Pasadena, CA., Report No. NSF-RA-N-74-159, 1974) pp 115-121.

G. V. Keller, "Dipole method for deep resistivity studies", Geophysics, v. 31 (1966) pp 1088-1104.

G. V. Keller, "Induction methods in prospecting for hot water", United Nations Symposium on the Developnent and Utilization of Geothermal Resources, Pisa (Geothermics, Special Issue No. 2, vol. 2, part 1, 1970) pp 318-332.

G. V. Keller and F. C. Frischknecht, Electrical Methods in Geophysical Prospecting, (New York, Pergamon Press, 1966).

R. N. Kerr, R. Bangma, W. L. Cooke, F. G. Furness, G. Vamos, "Recent Developments in New Zealand in the Utilization of Geothermal Energy for Heating Purposes", in Proc. U. N. Conf. on New Sources of Energy, Rome, 1961, (United Nations, New York, 1964) Vol. 3, Paper G/52.

B. Kohler, "The Economic and Environmental Aspects of District Heating in Sweden", District Heating, October-November 1973, pp 22-25. 
S. Komagata, H. Nakamura and Y. Minokara, "The status of geothermal utilization in Japan", United Nations Symposium on the Development and Utilization of Geothermal Resources, Pisa (Geothermics; Special-Issue No. 2, vo1. 2, part 1, 1970) pp 185-196.

O. A. Kremnjov, V. Ja. Zhuravlenko, A. V. Shurtshkov, "Technica1-Economic Estimation of Geothermal Sources", Inited Nations Sympósium on the Development and Utilization of Geothermal Resources, Pisa (Geothermics, Special Issue No. 2, vol. 2, part 2, 1970) pp 1688-1696.

D. Lenzi, "Utilisation de 1 'energie geothermique pour la production de 1 'acide boriquet et des sous-produits contenus dans les 'soffione'", in Proc. U. N. Conf.. on New Sources of Energy, Rome, 1961 (United Nations, New York, 1964), Paper G/39.

B. Lindal, 1961a, "Geothermal Heating for Industrial Purposes In Iceland", in Proc. U. N. Conf. on New Sources of Energy, Rome, 1961 (United Nations, New York, 1964), Paper G/5S.

B. Lindal, 1961b, "The extraction of salt from seawater by nultiple effect evaporators using natural steam", in Proc. U. N. Conf. on New Sources of Energy, Rome, 1961 (United Nations, New York, 1964), (Paper A 3/G, p. $27 f f$. )

B. Lindal, 1970a, "The Production of Chemicals from Brine and Seawater Using Geothermal Energy", United Nations Symposium on the Development and Utilization of Geothermal Resources, Pisa (Geothermics, Special Issue No. 2, vol. 2, part 1, 19.70), pp 910-917.

B. Lindal, 1970b, "The Use of Natural steam in a Diatomite Plant", United Nations Symposium on the Development and Utilization of Geothermal Resources, Pisa (Geothermics, Special Issue No. 2, vol. 2, Paper IX/11 (1970).

B. Lindal, "Industrial and other Applications of Geothermal Energy", in Geothermal Energy: Review of Research and Development (LC No.'72-97138, UNESCO, Paris, 1973) pp 135-148.

B. A. Lokchine and I. M. Dvorov, "Applications Experimentales et Industrielles de 1'Energie Geothermique en URSS", United Nations Symposium on the Development and Utilization of Geothermal Resources, Pisa (Geothermics, Special Issue No. 2, vo1. 2, part 2, 1970) pp 1079-1085.

V. Ludviksson and $B$. Lindal, Tillogur vardandi rannsoknir a sjoefnavinnslu. (Reykjavik, 1966).

V. Ludviksson, "The application of natural heat", The National Research Council of Iceland, Reykjavik, Iceland, (Report 70-3, in Icelandic, 1970). 
J. Lund, G. Culver and L. Svanevik, "Utilization of Geothermal Energy in Klamath Falls", in Proc. International Conference of Geothermal Energy for Industrial, Agricultural and Commercial-Residential Uses, Oregon Institute of Technology, Klamath Falls, Oregon, USA, 1974).

F. A. Makarenko, B. F. Mauritsky, B. A. Lokshin and V. I. Knonov, "Geothermal Resources of the USSR and Prospects for their practical use", United Nations Symposium on the Development and Utilization of Geothermal Resources, Pisa (Geothermics, Special Issue No. 2, vo1. 2, part 2, 1970) PP 1086-1091.

R. A. Marcello Jr. and R. K. Strawn, The cage culture of some marine fishes in the intake and discharge canals of a steam-electric generating station, Galveston Bay, Texas, National Technical Information Service, Springfielc, VA, Rept. COM-73-10140 (1972).

T. Marshall and W. Bralthwaite, "Corrosion control in geothermal system", in Geothermal Energy, Review of Research and Development, (UNESCO, Paris, 1973) pp 151-160.

Y. Mashiko and Y. Hirano, "New Supply Systems of Thermal Springs to Wide Areas in Japan", United Nations Symposium on the Development and Utilization of Geothermal Resources, Pisa (Geothermics, Special Issue No. 2, vol. 2, part 2, 1970) pp 1592̂-1595.

M. Matthiasson, "Beneficial uses of heat in Iceland", in Proc. Conf. on Beneficial Uses of Thermal Discharges, (New York State Department of Environmental Conservation, 1970).

K. Matsuo, "Drilling for Geothermal steam and Hot Water", in Geothermal Energy: Review of Research and Development (LC No. 72-97138, UNESCO, Par1s, 1973) PP 73-83.

P. Maugis, Societé Technique de Geothermie (France), Private Communication (1969).

A. Mazzoni, "The Steam Vents of Tuscany and the Larderello Plant", Bologna, Amonina Arts Grafiche, in English (1948) pp 59-75.

T. Meidav, "Electrical resistivity techniques in geothermal exploration", Geothermal Energy, 2, 4, (1974) pp 27-32.

T. Meidav and.R. Furgerson, "Resistivity studies of Imperial Valley geothermal area, California", Geothermics, 1, 2, (1972) pp 47-62.

J. W. Mercer Jr., and G. F. Pinder, "Galerkin finite-element simulation of a geothermal reservoir", Geothermics, 2, 3-4 (1973).

$i$ i:

L. J. P. Muffler, "Geothermal Resources", in U.S. Minera1 resources, U.S.G.S, paper No. 820, (1973) pp 251-261.

L. Muse', "A five-component magnetotelluric method in geothermal explorations, the M.T.-5-E.X.", Geothermics, 2, 2, (1973) pp 41-50. 
c. Otte, Drilling, Production, and Disposal Technology in Salton Sea, Calif. Dept. of Oil and Gas/Geothermal Resources Council, Short Course, Section $1, P$ O Box 1033, Davis, CA (1973)

G. Palmason, and J. Zoega, "Geotherma1 Energy Development in Iceland "1960-1969", United Nations Symposium on the Development and Utilization of Geothermal Resources, Pisa (Geothermics, Special Issue No. 2 , vol. 2 , part 1,1970 ) pp $73-76$.

K. Ragnars, K. Saemundsson, S. Benediktsson, and S.' S. Einarsson, "Development of the Namafjall Area, Northern Iceland", United Nations Symposium on the Development and Utilization of Geothermal Resources, Pisa (Geothermics, Special Issue No, 2 , vol: 2 , part 1, 1970) pp $925-935$.

G. M. Reistad, 1975, Analysis of Potential Nonelectrical Applications of Geothermal Energy and thetr Place in the National Economy, Lawrence Livermore Laboratory,-Rept. UCRL-51747, (1975)

G. Reistad, L. Boersma, L. Davis, J. Ringle, and W. Schmisseur, A Systems Analysis of the Economic Utilization of Warm Water Discharge from Power Generating Stations Oregon State Unfversity Englineering Experiment Station Bulletin 48, (1974)

R. W. Rex, "Investigation of the geothermal potential of the lower Colorado River basin, Phase 1--the Imperial Valley project", Inst. Geophys: Planetary Physics (University of California (Riverside), 1968).

R. W. Rex, Geothermal resources in the Imperial Valley, in Seckler, David, ed., California Water--a study in resource management, (University of California (Berkeley) Press, 1971).

G. Reynolds, Cooling with Geothermal Heat, United Nations Symposium on the Development and Utilization of Geothermal Resources, Pisa (Geothermics, Special Issue No. 2, vol. 2, part 2, 1970) pp 1658-1661.

S. Sato, "Selected Legal Aspects of Geothermal Development", presented at Conference on Research for the Development of Geothermal Energy Resources, Nationa1 Science Foundation/RANN, Pasadena, CA., Sept. 1974, Report No. NSF-RA-N-74-159 (1974).

A. V. Shcherbakow and V. I. Dvorov, "Thermal Waters as a source, for extraction of chemicals", United Nations Symposium on the Development and Utilization of Geothermal Resources, Pisa (Geothermics, Special

ic. Issue No. 2, vo1? 2, paper V/10 (1970).

H. Sigurdsson, "Reykjavik Municipal District Heating Service and Utilization of Geothermal Energy for Domestic Heating", In Proc. U. N. Conf. on New Sources of Energy, Rome, 1961. (United Nations, New York, 1964), vo1. 3, paper G/45. 
J. H. Smith, "Geothermal Development in New Zealand", United Nations Symposium on the Development and Utilization of Geothermal Resources, Pisa (Geothermics, Special Issue No. 2, vol. 2, part 1, 1970) pp 232-247.

Stanford Research Institute, Patterns of Energy Consumption in the United States, (1972).

R. Stone, "Leasing of Federal Geothermal Resources", in Proc. Conf. on Research for the Development of Geothermal Energy Resources, Sept. 1974, (National Science Foundation/RANN, Pasadena, CA, Rept. No. NSF-RA-N-74-159, 1974) Pp 122-127.

G. Sukharov, S. Vlasova, and Y. Taranukha, 1970, "Utilization of Thermal Waters from 011 Deposits of the Caucasus", U. N. Symp. on Development and Utilization of Geothermal Resources, Pisa (Geothermics, Special Issue No. 2, vol. 2, part 1, 1970) pp 1102-1115.

A. N. Tikhonov and I. M. Dvorov, "Development of Research and utilization of geothermal resources in the USSR", United Nations Symposium on the Development and Utilization of Geothermal Resources, Pisa (Geothermics, Special Issue No. 2, vol. 2, part 2; 1970) pp 1072-1078.

H. Torfason, "The Law of Iceland as it Affects Geothermal Development", In Proc. Second U. N. Conference on the Development and Uses of Geothermal Energy, San Francisco, CA, (1975). (In preparation).

U. S. Department of the Interior, Bureau of Reclamation, Geothermal Resource Investigations, East Mesa Test Site, Imperial Valley, CA, status report, November, 1974 .

A. Valfells, "Heavy water production. with geothermal steam", (in Icelandic) Nuc1. Sc1. Comm., Reykjavik, (1959).

A. Valfells, "Heavy water production vith geothermal energy", United Nations Symposium on the Developnent and Utilization of Geothermal Resources, Pisa (Geothermics, Special Issue No. 2, vol. 2, part 1, 1970) p. 896-900.

A. Valfelis, B. Lindal, and V. Ludviksson, An estimate of heavy water manufacturing costs in Iceland (Iceland National Research Council, Reykjavik, (1969).

G. A. Waring, Thermal Springs of the United States and Other Countries of the Wor1d, A Summary, U.S. Geo1. Surv. Prof. Paper, No. 492 (1965).

D. L. Warner and D. H. Orcutt, "Industrial Waste Water-Injection Wells in United States, States of Use and Regulation, Underground Waste Management and Artificlal Recharge vol. 2, 1973. p. 691.

M. Wells, "Early Development of Western Geothermal Resources", Journal of the West, X, 1, 1971. pp 53-71. 
H. H. Werner, "Contribution to the mineral extraction from supersaturated " geotherma1 brines, Salton Sea Area, Californial, United Nations Symposium on the Development and Utilization of Geothermal Resources, Pisa (Geothermics, Special Issue No. 2, vol. 2, 1970).

D. E. White, "Geochemistry applied to the discovery, evaluation and exploitation of geothermal energy resources", United Nations Symposium on the Development and Utilization of Geothermal Resources, Pisa (Geothermics, Special Issue No. 2, vo1., 2, part 1,1970 ) pp 58-80,

R. L. Whiting, "Drilling and production of geothermal resources, in Proc. Soc. Petrol, Eng. Deep Drilling and Production Symposium, Amarilio, Texas, Sept. 1974, SPE Paper No. 5169, IIb, (American Institute of Mechanical Engineers, Da11as, 1974).

R. D. Wilson, The Develópment ôf Geóthermal Steam Resourcés, J. Tech. Ass. Austral. New Zealand Pulp Paper Indus. 23,28 (1969).

C. M. Wong, "Geotherma1 energy and desalination partners 1n progress", United Nations symposium on the Development and Utilization of Geothermal Resources; Plisa (Geothermics, Special Issue No. 2, vo1. 2, part 1, 1970) pp 892-895.

World Meteorological Organization, Instruments and methods of observations Water temperatures. Guide to hydrometeorological practices; No. 168, (1965) pp 44-52.

M. M. Yarosh, B. L. Nichols, E. A. Hirst, J. Michel, and W. C. Yee, Agricultural and Aquacultural Uses of Waste Heat, Oak Ridge National Laboratory, Rept. ORNL-4797 (1972).

J. Zoega, "The Reykjavik Municipal Heating System", In Proc. International Conf. on Geothermal Energy for Industrlal, Agricultural, and Commercia1-Residential Uses, 1974 (Cregon Institute of Technology, Klamath Falls, Oregon, 1974).

J. Zoega and G. Kristinsson, "District Heating for Old and New Town Development", in Proc. First International District Heating Convention, London, 1970 . 


\section{Appendix A: Minutes of the CCMS Nonelectrical Project Pilot-Study Meeting, Paris, France, June 25, 1975}

MINUTES

The meeting was called to order at 9:00 a.m. by Dr. J. H. Howard of Lawrence Livermore Laboratory, Chairman of the Non-electrical Project. The announced agenda for the meeting is given in Attachment 1. A list of those attending the meeting is given in Attachment 2.

Dr. Howard, who is also editor for the Status Report on Non-electrical Applications of Geothermal Resources, explained the current situation regarding the report. In brief, all sections of the report have been written (see Attachment 3). All but the sections on Legal and Institutional Considerations and on Economics are ready to be passed on to a technical editor at Lawrence Livermore Laboratory for editorial rewrite in preparation for printing of the report.

Dr. Howard explained what he thought were the principal conclusions of the study as welli as the needs made apparent by the study. Inasmuch as these conclusions and needs have been explained in the Lawrence Livermore Laboratory Report* which was distributed to all CCMS GPS

(Geothermal Pilot Study) representatives, they w111 not be restated in these minutes. A major topic of the agenda was consideration of a statement of general recommendations. It was agreed that, in view of the comments made during the meeting about the draft of this statement, that Dr. Howard would revise the statement. Following revision, the statement would be returned to all GPS Non-electric Project Representatives. Presumably they would accept the minor revisions made and would then pass this general statement on to their respective governments with the expectation that participating governments would vote to affirm the statement when presented to the CCMS Plenary. A copy of the revised statement is attached (Attachment 4), and it serves in a sense as "policy" framework for future actions by the CCMS GPS Non-electrical Project. The chairman called for consideration of a number of topics, and a summary of the discussion of these topics is summarized below.

\section{Economics of Non-electrical}

Applications: A topic of major interest

*J.H. Howard, Principal Conclusions of the Committee on the Challenges of Modern Soclety Nonelectrical Applications Project, Lawrence Livermore Laboratory, Preprint UCRL-76408 (1975). 
to the delegates was the economics of non-electrical applications of geo-

thermal resources. Major factors affecting economics are the interest rates that are paid on funds borrowed to carry out a project and the sales price of energy sold. In some, if not most countries of the CCMS GPS, government decisions control both of these factors.

The group present called for exploring more fully the general problem of the economics of nonelectrical applications of geothermal resources to heating and cooling of residences. Following the meeting, C. H. Bloomster (U.S.A.) presented a written statement of such a project. It is included as Attachment 5 . Two points emphasized by

0. Kappelmeyer (FRG) were as follows: Geothermal energy is not always as inexpensive as many assume, especially when the enthalpy of the resource is low, and its value must always be compared with other sources of energy, e.g., coal, nuclear, etc. Furthermore, waste industrial heat may be of quality as good as that recoverable from geothermal resources in some geographic areas.

\section{Government Participation in} Non-electrical Applications Projects. The extent of government participation in non-electrical applications pro- jects varies from minimal involvement, as In the United States, to strong participation as in the case of France and Hungary. Where government participation is strong, such participation is clearly guided by a desire to encourage evaluation and development: of geothermal resources. The pattern appears to be that government will work in partnership with the private sector and 'will take the initial risks' and absorb any losses that might develop should the venture fail. Should a ? venture prove out, however, the private sector, which worked cooperatively with government, is called upon to assume responsibility for the project and to pay back through sales of geothermal energy the investment cost of the project plus some agreed to amount of interest.

3. Possibility of a Review Pane1 for Proposed Geotherma1 Non-electrical Projects. The possibility of assembling an ad hoc group of experts on non-electrical applications to review, evaluate, and perhaps, endorse proposals for non-electrical applications was discussed. Although no vote was taken, it seemed to be the consensus of the group that review and evaluations by such a group were acceptable procedures but that outright endorsement exceeded the purview of the CCMS GPS: 
4. Publicity. The question of publicity for non-electrical applications was raised. It was agreed that restrained, realistic statements about the prospects for non-electrical uses of geothermal resources should be encouraged and that poorly supported claims should be avoided. Those' present seemed to feel that publicity to date for non-electrical geothermal applications had been appropriate.

5. Discussion of a Specific Task for the Next Phase of the Non-electrical Project. There was no specific hardware-centered task that the group felt might be the focus of the next phase of the project. Work on heat exchangers showed signs of becoming such a topic; but, as noted below (paragraph 7), economics studies emerged as the problem of major concern. Mention was made of the possibility of underground storage of waste industrial heat and of work on heat exchangers.

Speaking for the United States, Dr. Howard stated that he would urge that the U. S. try Independently to direct some of its effort on normalgradient geothermal resources into: non-electrical applications.

6. Miscellaneous Comments. In response to a question by $\mathrm{Dr}$. Barbier (Italy), it was explained that the final Status Report would be distributed to all representatives of the CCMS GPS, to members of the Nonelectrical Project, and to all others who had expressed an interest in the project.

7. Future Course of the Project. Acting on behalf of the Director, CCMS GPS, Dr. James C. Bresee, Dr. Howard asked Dr. Paul Sangnier, Head of the French delegation if France would assume the lead role for the Non-electrical Project for the next year or two or until it seemed appropriate for some other country to play the lead role. Dr. Sangnier said that he would investigate the possibility of this role for France and would confirm a decision shortly.

Dr. Howard also announced that he would be leaving the Non-electrical Project toward the end of this summer, and that his responsibilities as Head of: the U. S. Non-electrical Project would be taken over by Dr. Jay F. Kunze of Idaho National Engineering Laboratory ("INEL"), Idaho Falls, Idaho.

There was an expression of interest in more clearly understanding the economics of non-electrical applications, and the consensus of the group was that a new phase of the project which would address this topic should be undertaken. French, German, and U. S. representatives were particularly 
concerned, and as noted above, Bloomster submitted the plan given in Attachment 5 .

It was agreed that Howard would summarize the proceedings of this meeting as well as the informal session in San Francisco in order to prepare the last chapter of the status report.

It was also agreed that the group would try to meet again, possibly using a workshop mode within six months in order to define more clearly the tasks of evaluating the economics of non-electrical applications.

ATTACHMENT 1: AGENDA FOR CCMS GEOTHERMAL PILOT STUDY NON-ELECTRICAL PROJECT, PARIS, JUNE 25, 1975

\section{9:00 Review of Status of Non-electrical Report}

10:15 Discussion of unresolved technical and institutional problems

11:15 Discussion of draft statement of general recommendations

$2: 15$ Continuation of discussion of general recommendations

3:15 Consideration of last chapter of status report and projects for future work.

\section{ATTACHMENT 2: .. LIST OF ATTENDEES}

Oskar Kappelmeyer

Director of Subsection

Exploration Geophysics

Geological Survey of Germany

3 Hannover

Buchholz, Germany

John D. Garnish

B1dg. 10-28

A.E.R.E., Harwell

Didcot

Oxon, England

Mario Fane11i

International Institute for

Geothermal Research

Pisa, Italy.

Enrico Barbier

International Institute for Geotherma1 Research

Pisa, Italy

Jay F. Kunze

Aerojet Nuclear/Idaho Nat1.

Engr. Laboratory

550 2nd Street

Idaho Falls, Idaho 83401

J. H. Howard

Lawrence Livermore Laboratory

Untversity of California

P. O. Box 808

Livermore, California 94550

Cameron Sanders

Delegation of the United States

NATO

Brussels

Paul Sangnier

D.G.R.S.T.

35 Rue Saint-Dominique

75007 Paris, France 


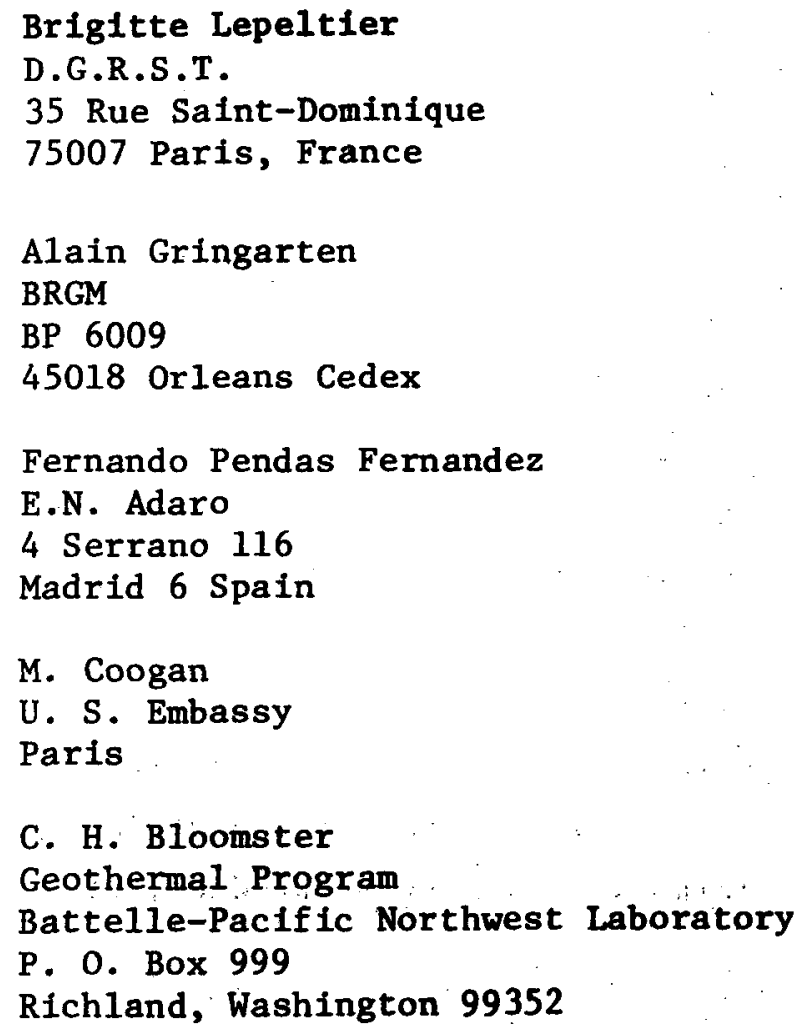

ATTACHMENT 3: CONTENTS OF THE CCMS GEOTHERMAL PILOT STUDY REPORT ${ }^{*}$ ON THE STATUS OF NON-ELECTRICAL APPLICATIONS OF GEOTHERMAL RESOURCES

\section{Preface and Acknowledgments}

I. Introduction

A. Purposes of the Report

B. Short History of the Project

C. Importance of Non-electrical Applications of Geothermal Resources

\footnotetext{
${ }^{\star}$ As of June 25,1975
}

II. Non-electrical Geotherma1

Systems Development
A. Finding the Explitable Resources
B. Drilling, Extraction and Distribution
C. Uses
D. Disposa1

III. Applications
A. Residential and Commercial Applications
B. Agricultural and Related Topics
C. Industrial Applications

IV. Economics and Regulation

A. Regulatory Considerations in the Development of Geothermal Resources

B. Economics of the Production and Use of Geothermal Heat for Non-electrical Uses.

V. Present Problems and Future Possibilities

VI,. References and Other Information

VII. Appendix of Special Contributions

A. Developments in Italy

B. Developments in Turkey

C. Developments in New Zealand

D. Developments in the Phillippines

E. Agricultural Applications of Geothermal Energy 
ATTACHMENT 4: CCMS GEOTHERMAL PILOT STUDY NON-ELECTRICAL PROJECT STATEMENT OF GENERAL RECOMMENDATIONS

The Non-electrical Project Subcommittee of the CCMS Geothermal Pilot Study recommends that governments of countries participating, in the project and those of other nations interested in non-electrical applications of geothermal resources whole-heartedly and constructively support efforts in the following areas:

\section{Geotherma1 Exploration.} Programs to inventory national geothermal resources that are suitable for non-electrical applications should be supported. Programs directed at the definition of the qualities of specific resources at a level of detail necessary for purposes of successful exploitation for non-electrical uses should also be supported, The latter program should include not only efforts at definition of specific geographic resources using known technologies but should also include work on improved geological and geophysical techniques of definition:

\section{Demonstration of Applications.} The demonstration, even if seemingly technologically simple, of nonelectrical applications using available indigenous resources in an appropriate and techically sound:manner should be carried out under instrumentally monitored conditions.

3. Research and Development on New Applications. The evaluation of experimentally untested ideas for the application of geothermal resources should be supported beyond conceptüal analyses through at least a phase of small-scale experiments. Examples of such applications include the development of improved and less costly heat exchangers, protein farming, freezing of produce, etc.

\section{Financing. Support by} government entities for financing favorable to the development of geothermal resources for non-electrical purposes is necessary. Such support might include guarantees of loans and interest rates and vartous forms of governmental financial participation in relatively high risk applications and in applications which are apparently simple but are being done for the first time.

\section{Interfacing Electrical and} Non-electrical Applications of Geotherma1 Resources. Programs to advantageously combine in series and in parallel electrical and nonelectrical applications of the same geological resource should be encouraged. 
6. Improvement of Legal Framework. Non-electrical applications of geothermal resources are affected by existing laws. Although it is recognized that laws governing geothermal resources vary from country to country, it is proposed that reasonable changes in laws, that is, changes that are not in violation of the spirit of fair play, should be advocated so as to enhance the growth of non-electrical applications. Examples, which are believed to be applicable only to the United States, would be repeal of ad valorem taxes on identified resources and treatment with respect to taxation on income that is consistent with the risks involved with new ventures and with the concept of depletion of natural resources.

\section{Educational and Information} Aspects. The exchange of information relative to non-electrical uses should be encouraged. Such information exchanges include: publications; symposia, workshops intended to provide an in-depth review of newly developing projects; programs of exchange of estabilished scientif ic and academic personnẹ l and students; and public information services directed at lay individuals who have an interest in non-electrical applications of geothermal resources.
8. Joint Projects. Ef forts should be made to maximize effective use of internationally available technology and experience in the overall area of non-electrical uses through joint development and demonstration-project activity.

ATTACHMENT 5: STATEMENT OF A PROJECT ON THE ECONOMICS OF NON-ELECTRICAL APPLICATIONS OF GEOTHERMAL RESOURCES *

1. This project would undertake a systematic analysis of the value of geothermal energy for district heating and cooling as a function of: (1) climate, (2) population density, (3) population size, (4) resource quality (including enthalpy and physical/chemical properties), depth, (6) location relative to population, and (7) interest rates. These values would be compared with the costs of alternative sources of energy: The project would: (1) define key technical factors, (2) key economic assumptions and would (3) endeavor to clarify financial analysis procedures and techniques. The result of the project would be a statement of the relative value of geothermal resources available for non-electrical applications under ${ }^{*}$ By C: H. Bloomster, Batelle NorthWest Laboratories, Richland, Washington, U.S.A., with slight modification by J. H. Howard for purposes of these minutes. 
various conditions and locations and also a clear understanding of the

procedures whereby these evaluations were carried out.

\section{Appendix B: Italian Nonelectrical Uses of Geothermal Resources}

APPLICATIONS

\section{Galzignano (Padua).}

Location: Long $11^{\circ} 43^{\prime} \mathrm{E}$ and Lat $45^{\circ} 17^{\prime} \mathrm{N}$

Artesian water: $65^{\circ} \mathrm{C}$ at the wellhead Salinity (at $180^{\circ} \mathrm{C}$ ): on average

$3 \mathrm{~g} / 1$, essentially $\mathrm{NaCl}$ and secondarily sulfates.

Reservoir: Cretaceous Iimestones Depth of we11 (one): 320 metres : Diameter: 6"'

Output: $\quad 10 \mathrm{l} / \mathrm{s}$

Use: Hëating of greenhouses for ornamental plants

Surface covered: $\quad 20,000 \mathrm{~m}^{2}$

Constructed in iron and glass.

Próperty of Euganea Floriculturists.

Driven by pumps, the water (at about $65^{\circ} \mathrm{C}$ ) circulates through a network of pipes which pass externally under huge cement tubs, raised above ground-level, in which the plants are cultivated: (Fig. B-1). The water partially cools and then passes (at about $40^{\circ} \mathrm{C}$ ) to other plant tubs which are at ground-1evel. (Fig. B-2). In winter, when the air temperature

*By Dr. Eririco Barbier in the greenhouses drops below $5^{\circ} \mathrm{C}$, supplementary air-heating is provided using hot water in thermoconvectors (Fig. B-1, near the roof). This water is heated in boilers using oil.

There are about $28 \mathrm{~km}$ of pipeline in the greenhouses; those on the outside of the tubs are in common iron whereas those on the inside of the tubs resting on the ground are in PVC plastlc." The various plants cuitivated are Diffenbachia, Ficus, Philodendron, Sansevieria. and is. Discharge: The used hot water is discharged into a ditch without any preliminary process being carried out.

Economics: A saving of $30 \%$ compared to oil-heating.

Ownership: It is the private enterprise of a floricuitural cooperative called the Euganea Floricultorl, with financial backing from the European Economic Community.

\section{Larderello area (Tuscany).}

Location: Castelnuovo Val, Di Cecina Long $10^{\circ}-34^{\prime}$ E and Lat $43^{\circ} 13^{\prime}, \mathrm{N}$ Source: The greenhouses are located in the area of Larderello geothermal steam field. They are heated. 


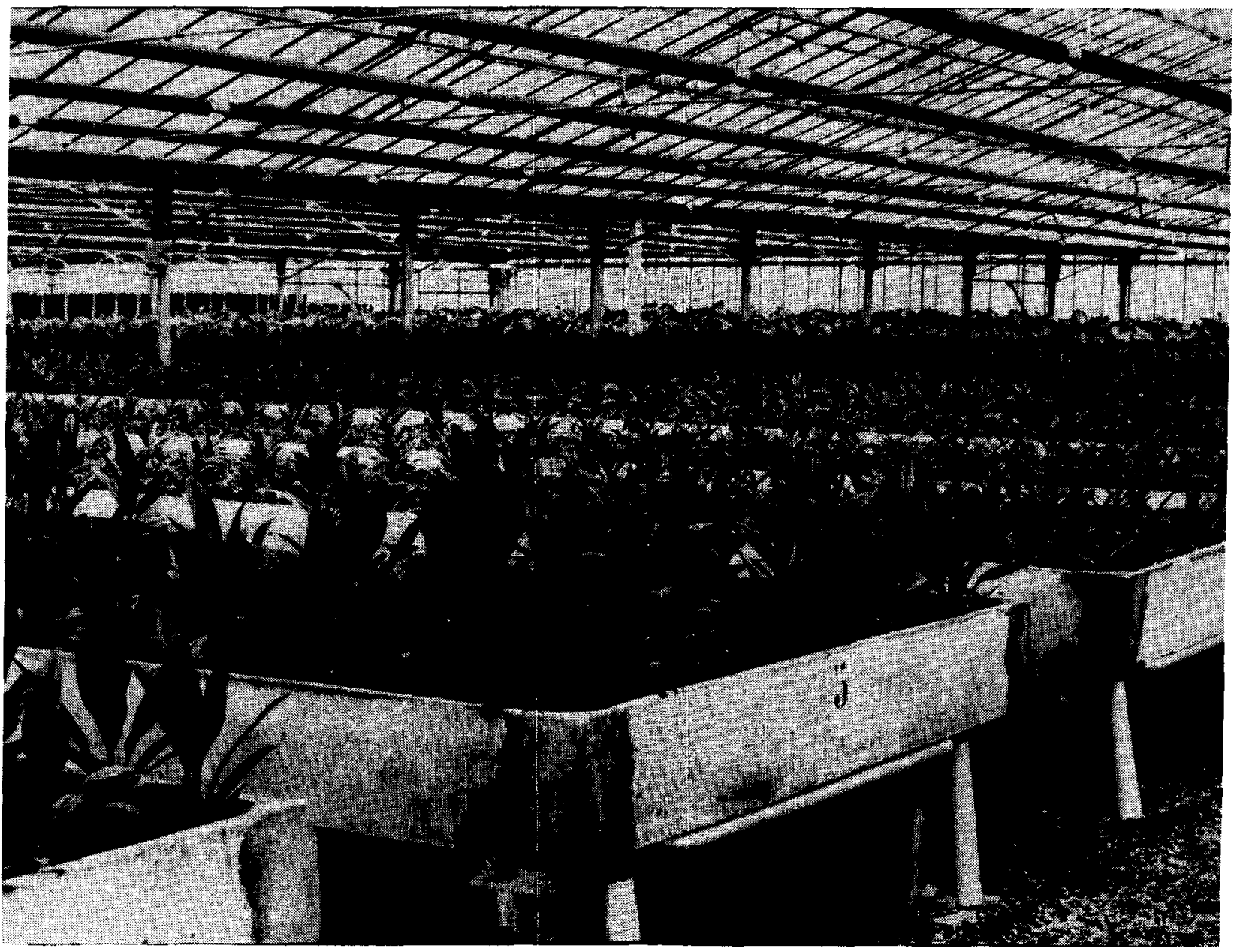

Fig. B-1. Italy - Galzignano (Padua): View of cement tubs heated by thermal waters in a greenhouse.

directly by steam at a low pressure and temperature originating in the

'Rossi V.' well. This steam is at saturation limit and carries water. The greenhouses take all the production of this well (Fig. B-3). Pressure: 1.13 absolute at, $103^{\circ} \mathrm{C}$. Steam consumption is on average $1.3 \mathrm{~kg} / \mathrm{h} / \mathrm{m}^{2}$.

Surface covered: $4792 \mathrm{~m}^{2}$.

Construction: Greenhouses con-

structed in teakwood, glass and metal and glass. Property of ENEL (National
Electric Energy Agency). The steam circulates in thermoconvectors placed along the inside edge of the glass surface (Fig. B-4). The pipes are in 3" iron (Fig. B-5).

3. Lago (a few kilometres from Castelnuovo)

Source: The greenhouses are heated directly by high quality steam, which feeds the Lago power plant (33.5 MW). This steam comes from Carboli A. and Capannini (2 wells). Surface covered: $1950 \mathrm{~m}^{2}$. 


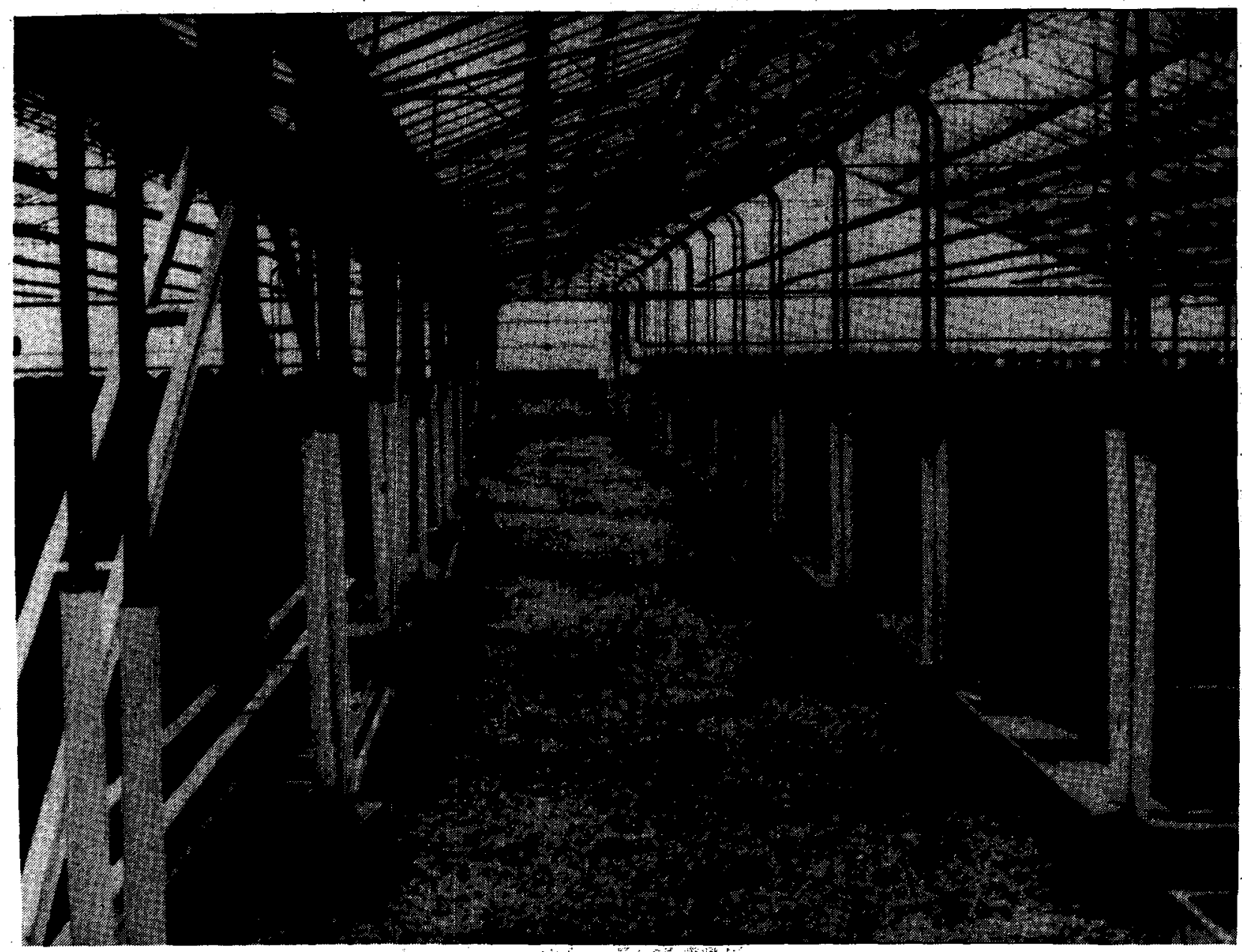

Fig. B-2. Italy - Galzignano (Padua): Plant tubs at ground level heated by thermal water at $50^{\circ} \mathrm{C}$.

Construction: Greenhouses constructed in metal and glass, showing obvious signs of corrosion due to the strong C1 atmosphere at Lago (Fig. B-6). Property of ENEL.

Notes: The steam circulates in thermoconvectors as in the greenhouses of Castelnuovo. The greenhouses in operation at Castelnuovo and Lago produce an average of $4000 \mathrm{t} / \mathrm{yr}$ of tomatoes, $1600 / 1000 \mathrm{t} / \mathrm{yr}$ of baby marrows, $1000 / 1200 \mathrm{t} / \mathrm{yr}$ of green beans, and some basil.

The ground is disinfected by heat exchangers, a series of pipes at a depth of $30 \mathrm{~cm}$, all of them lined and placed at about $20 \mathrm{~cm}$ distance from one another. These pipes are $3 \mathrm{~m}$ long. Heating generally takes place from December to April. 


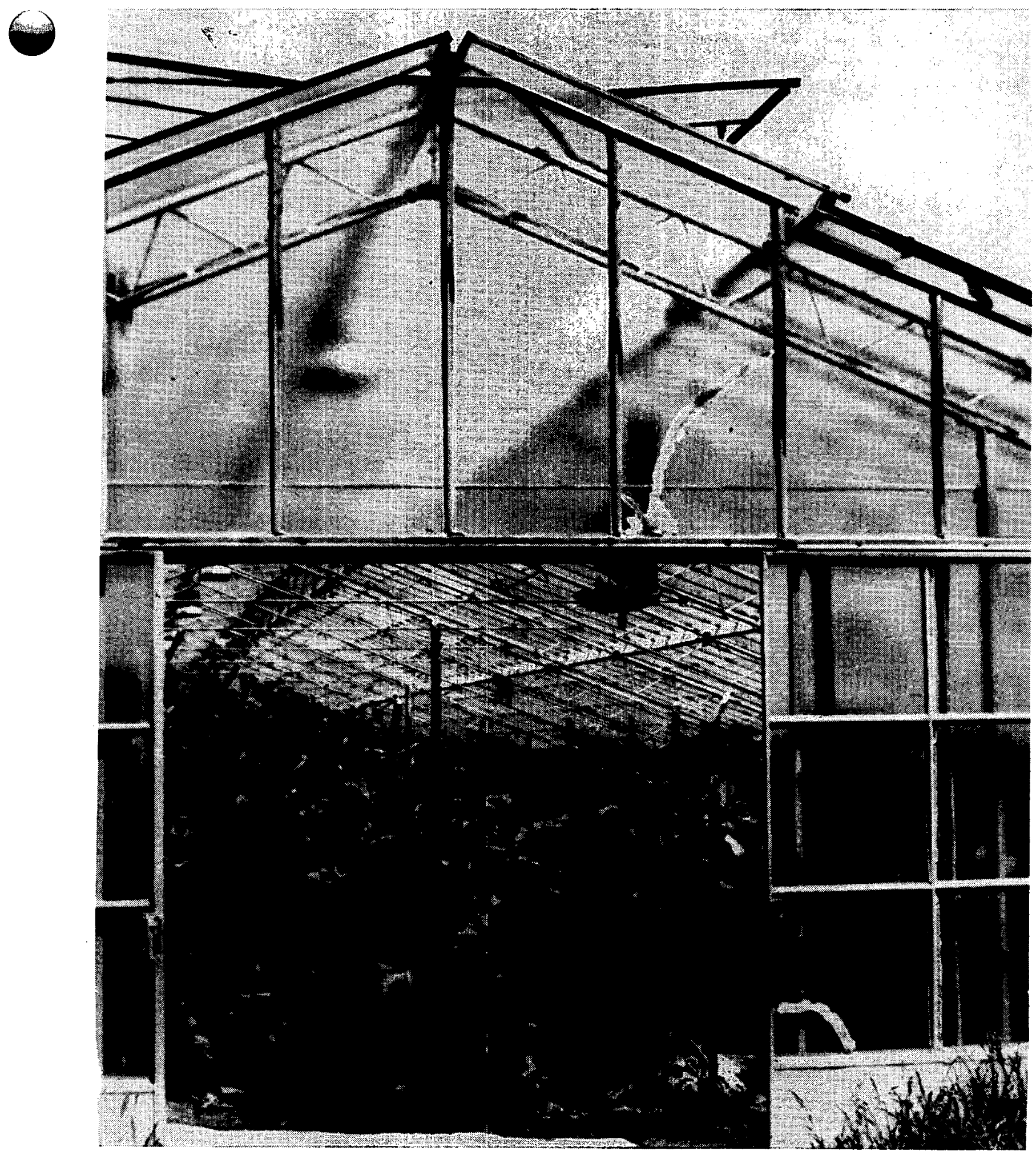

Fig. B-3. Italy - Castelnuovo Val di Cecina (Larderello Area, Tuscany): Greenhouse heated by geothermal steam. 


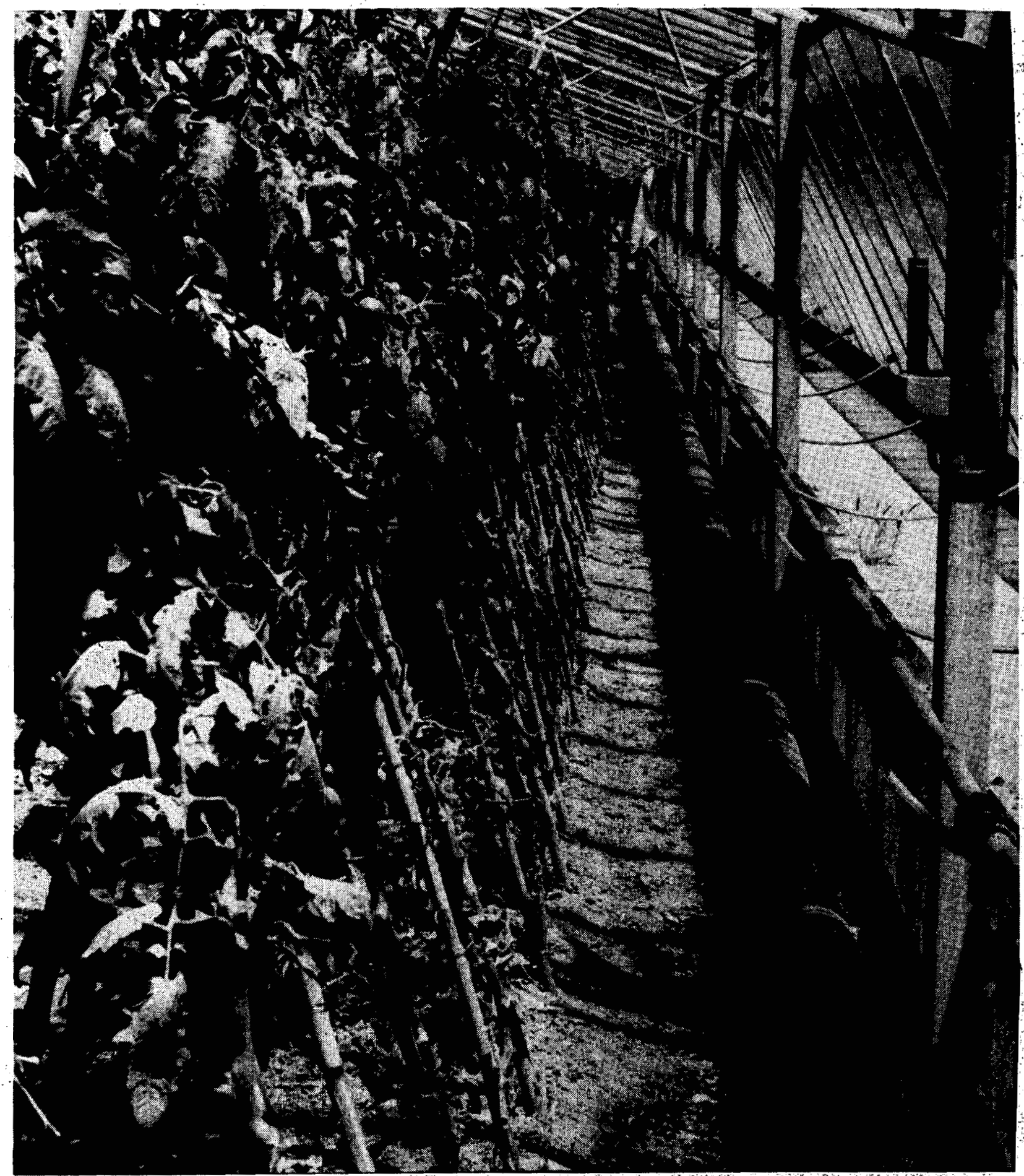




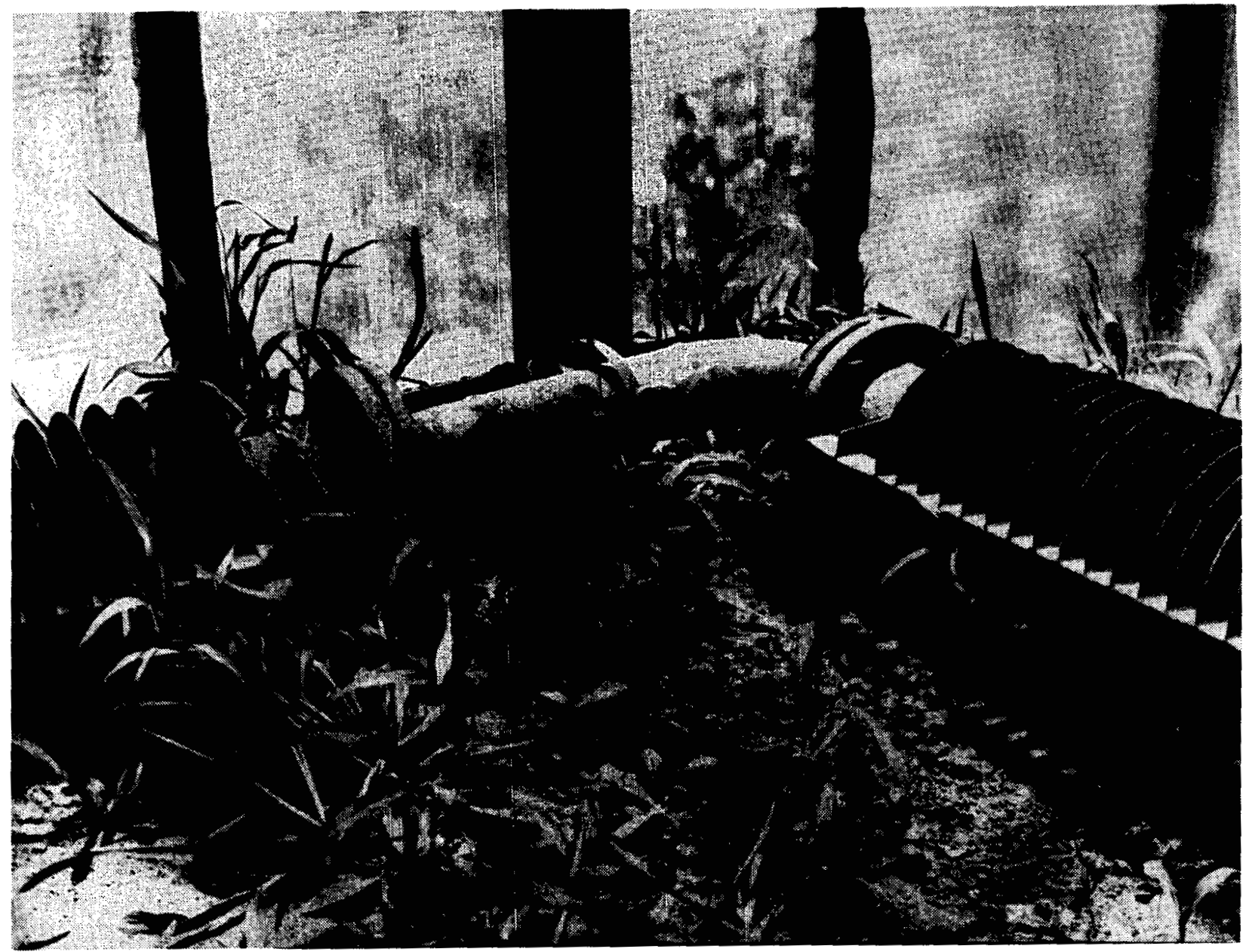

Fig. B-5. Italy - Castelnuovo Val di Cecina (Larderello Geothermal Area, Tuscany): Close up view of thermoconvector in a greenhouse.

DOMESTIC HEATING

4. Abano Terme (Padua).

Lacation: Long $11^{\circ} 47^{\prime}$ and Lat $45^{\circ}$ $20^{\prime}$.

Source: Thermal waters from 113 active wells.

Temperatures: from 65 to $87^{\circ} \mathrm{C}$ Salinity: from 2.3 to $6 \mathrm{~g} / 1$, essentially $\mathrm{NaCl}$ and secondarily sulfates.
Depth of wells: from 250 to $400 \mathrm{~m}$, average.

Output: $4501 / \mathrm{s}$, with peaks of $6001 / \mathrm{s}$ and minima of $250 \mathrm{l} / \mathrm{s}$.

Use: Heating of 74 hotels-spas and severa1 private houses, using heat exchangers (Fig. B-7).

Discharge: The cooled water is discharged in drains without any previous processing.

Costs: The cost of the heating is due only to the maintenance of the 


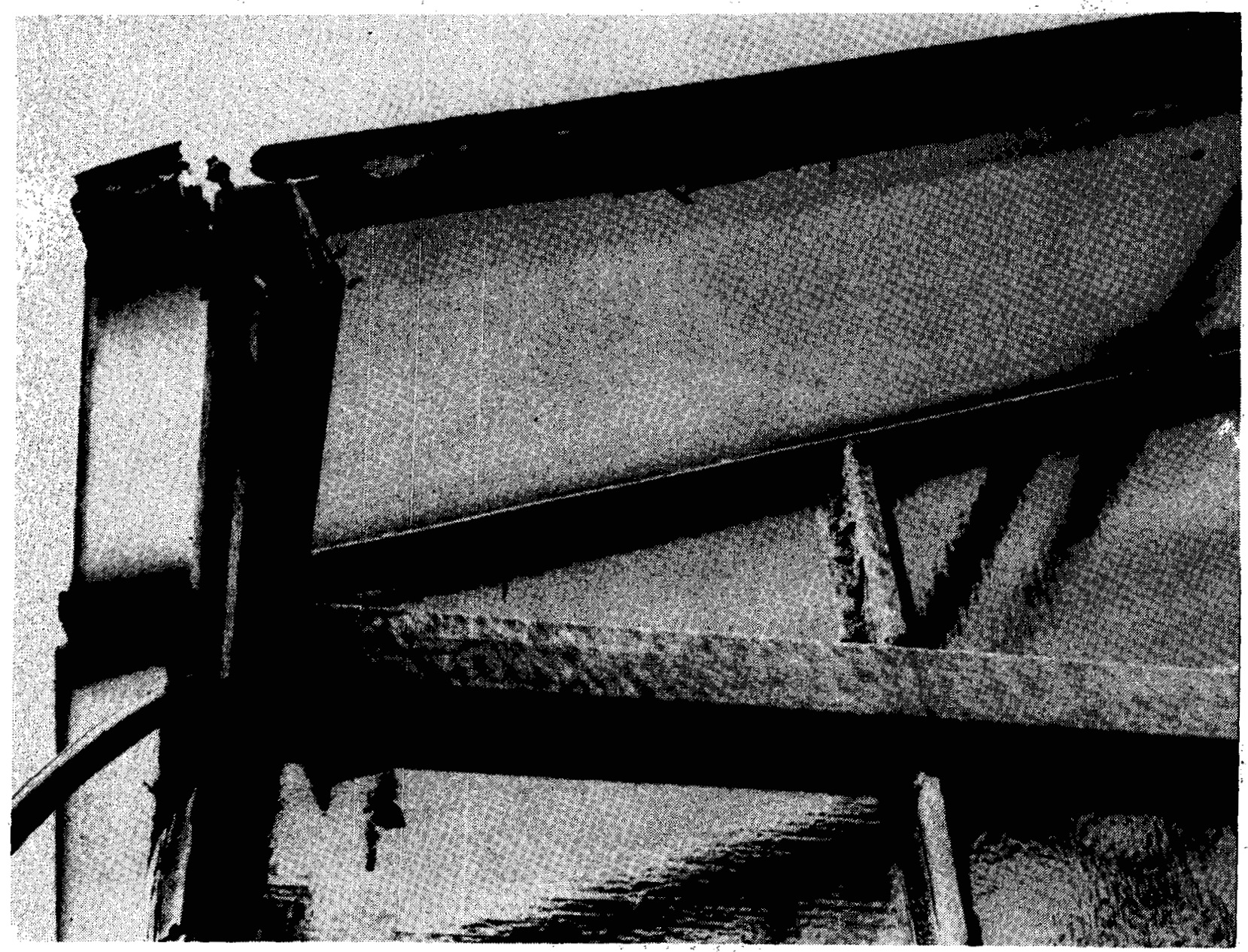

Fig. B-6. Italy - Lago (Larderello Geothermal Area, Tuscany): Signs of corrosion due to the strong chlorine atmosphere in a glass/metal greenhouse.

heat exchangers; the thermal waters used for this purpose are then utilized in the spas.

Ownership: This is a private enterprise and all expenses are paid by the proprietors of the hotels-spas.

5. Lardere1lo area (Tuscany). General: Since the 1920's the geothermal steam in the boraciferous zone of Larderello has been used for spaceheating (by means of thermoconvectors) and for providing hot water to the houses (with heat exchangers) (Fig. B-8).

Use: At the moment 501 flats $(85,500$ $\mathrm{m}^{3}$ ) as well as churches, cinemas, theatres, clubs, schools, etc. $\left(9,000 \mathrm{~m}^{3}\right)$ are heated using heat exchangers and low quality steam at $3.0 \mathrm{~atm}, 132^{\circ} \mathrm{C}$. Temperature at the outlet of the heat exchangers is about $70^{\circ} \mathrm{C}$. Consumption of steam (on average) is $0.12 \mathrm{~kg} / \mathrm{h} / \mathrm{m}^{3}$. There 


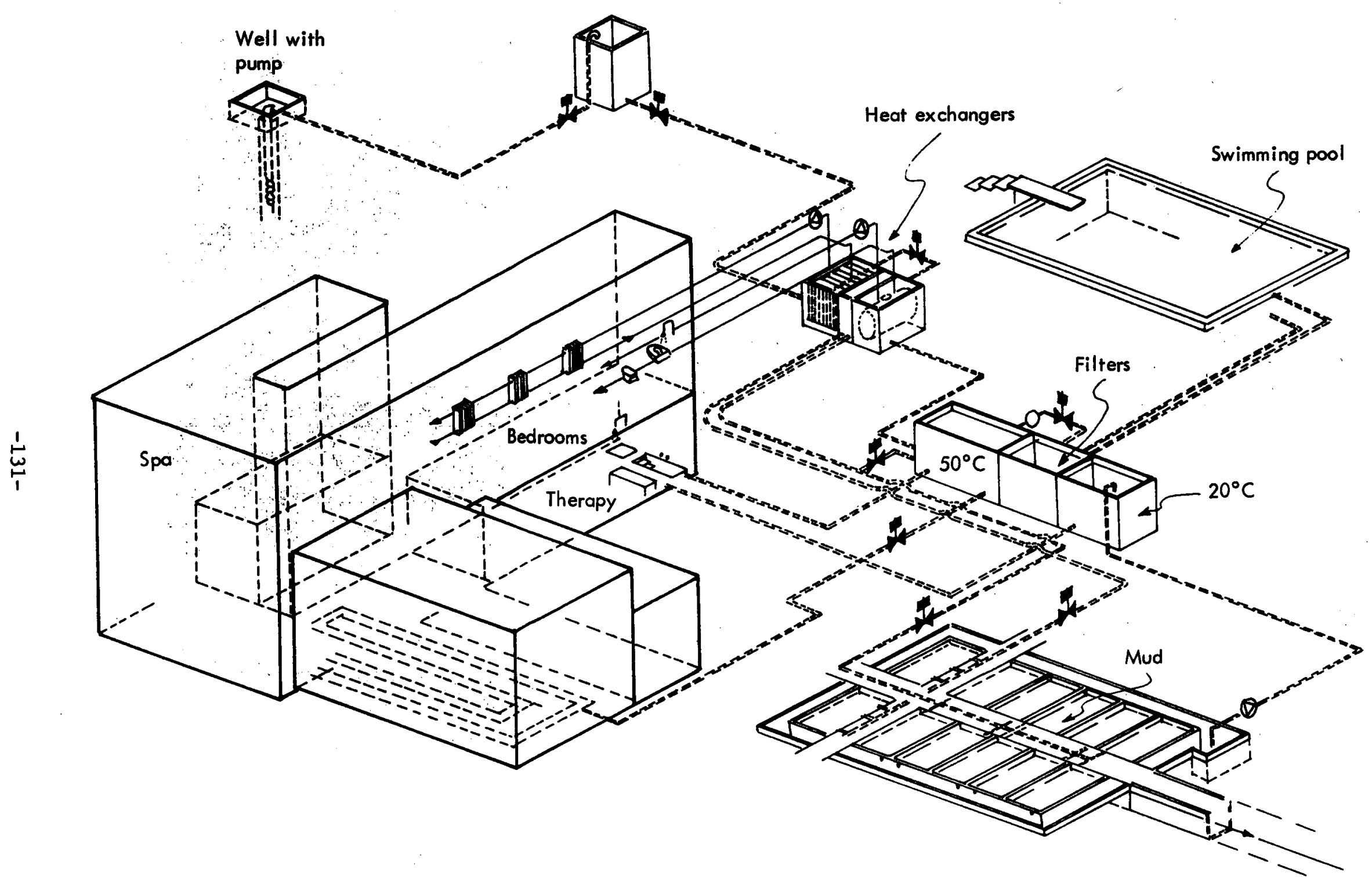

Fig. B-7. Sketch of a spa where thermal waters are also used for central heating, laundry, and toilet facilities. 


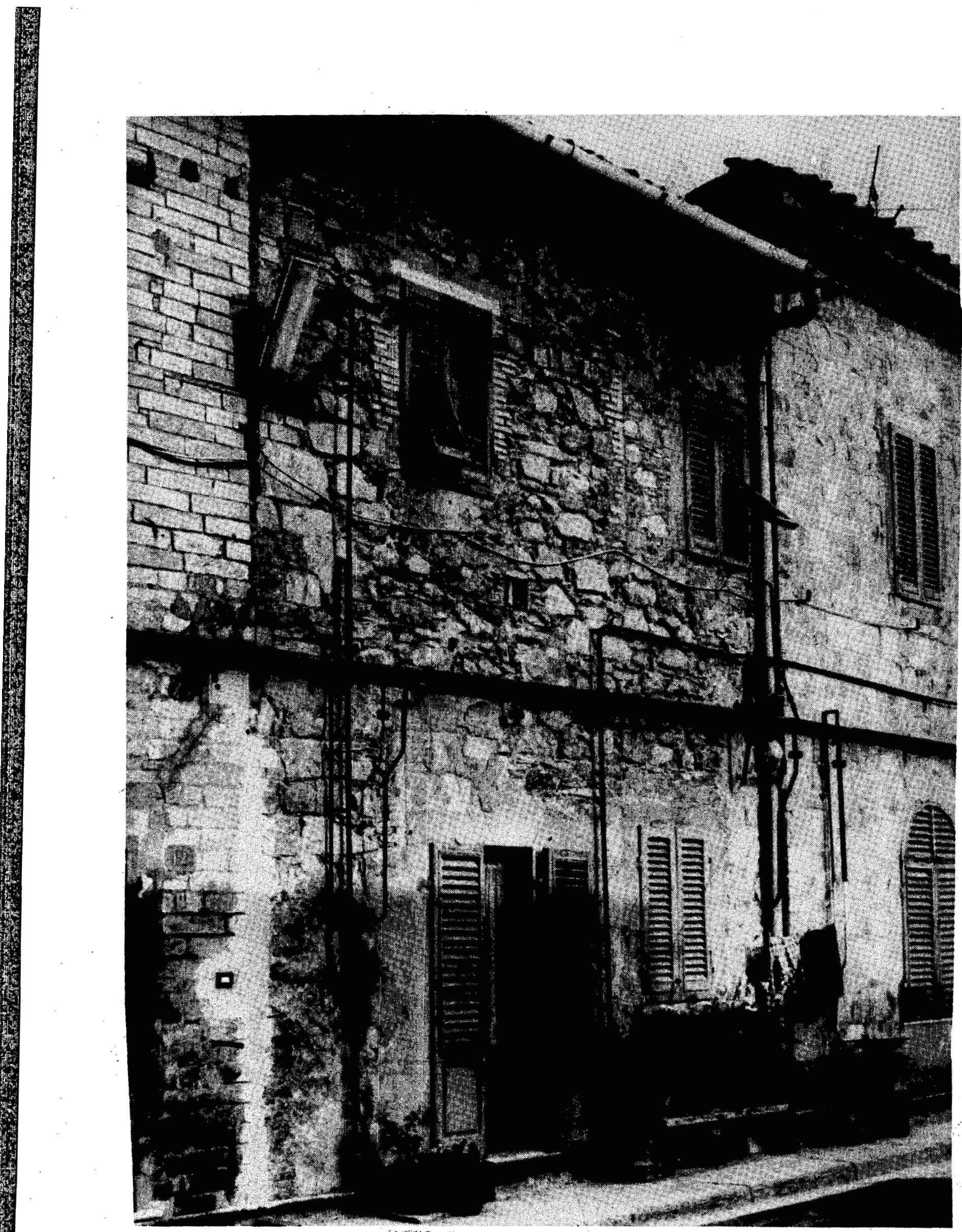

Fig. B-8. Italy - Lardere11o (Tuscany): old domestic heating system using geothermal steam. 
are also offices, workshops; storehouses $\left(27,000 \mathrm{~m}^{3}\right)$ which are all heated at $50 \%$ with direct steam and $50 \%$ using heat exchangers.

Discharge: The fluid utilized is discharged Into drains without any previous processing.

Costs: The costs of heating arise only from maintenance of the heat exchangers and pipes, as the steam used comes either from the wells no longer utilized in electricity generation : or is a small fraction of that used in the power stations.

Ownership: Property of ENEL, National Electric Energy Agency.

\section{OTHER APPLICATIONS}

This is only a partial list. In Italy there are several other places where there are hot springs utilized in spas and then for domestic heating in the same buildings. 


\section{Appendix C: Developments in Turkey}

GREENHOUSE HEATING IN KILZILDERE GEOTHERMAL FIELD, TURKEY

Geographic location: Kizildere geothermal field, Saraykoy-Denizli, Turkey.

Type of application: Greenhouse heating.

Mode of bringing resource on stream:

Government agency (Mineral Research and Exploration Institute of Turkey).

Method of disposal of spent brine:

To flow the disposal water into

Meander river.

Government regulations of application: Because of the boron content; amount of disposal water into Meander river is limited to 1000 tons per hour.

Installation costs: Installation cost of $1000 \mathrm{~m}^{2}$ pilot green house is about 80000 TL (5700 US dollars) including construction of greenhouse itself, heating system, irrigating water system and barracks for workers.

Maintenance requirements: Maintenance requirements are labor, electric power generator, fertilizer and irrigating water supply. Cost of these items is about 45000 TL (3200 US dollars) per year.

\footnotetext{
* by Ethem Tan
}

Discussion of "Engineering details" of application: Kizildere geothermal fluid has about 28 ppm boron content and so it is dangerous to let it flow into the greenhouse because any. small amount of leakage may be harmful for the plants there. To prevent this possibility a heating system is applied as shown in Fig. C-1. In this application geothermal fluid does not enter directly into the greenhouse but is used to heat the air by a heat exchanger (radiator) and this hot air is used to heat the greenhouse. The heat exchanger is placed outside of the greenhouse and the geothermal fluid passing through this heat exchanger is disposed into the river. There is a fan, driven by an electric motor, at the back of the heat exchanger and the hot air, heated by the heat exchanger is pushed by the fan into the hot air pipe in the greenhouse.

The greenhouse itself is a pilot one. It has dimensions of $20 \times 50 \mathrm{~m}$. Construction is iron and covered with plastics. Main hot air pipe in the greenhouse is made of aluminum and has a diameter of $60 \mathrm{~cm}$. This pipe has one hole for every plant row and plastic hoses are connected to these holes. Plastic hoses are along the plant rows and have many small 


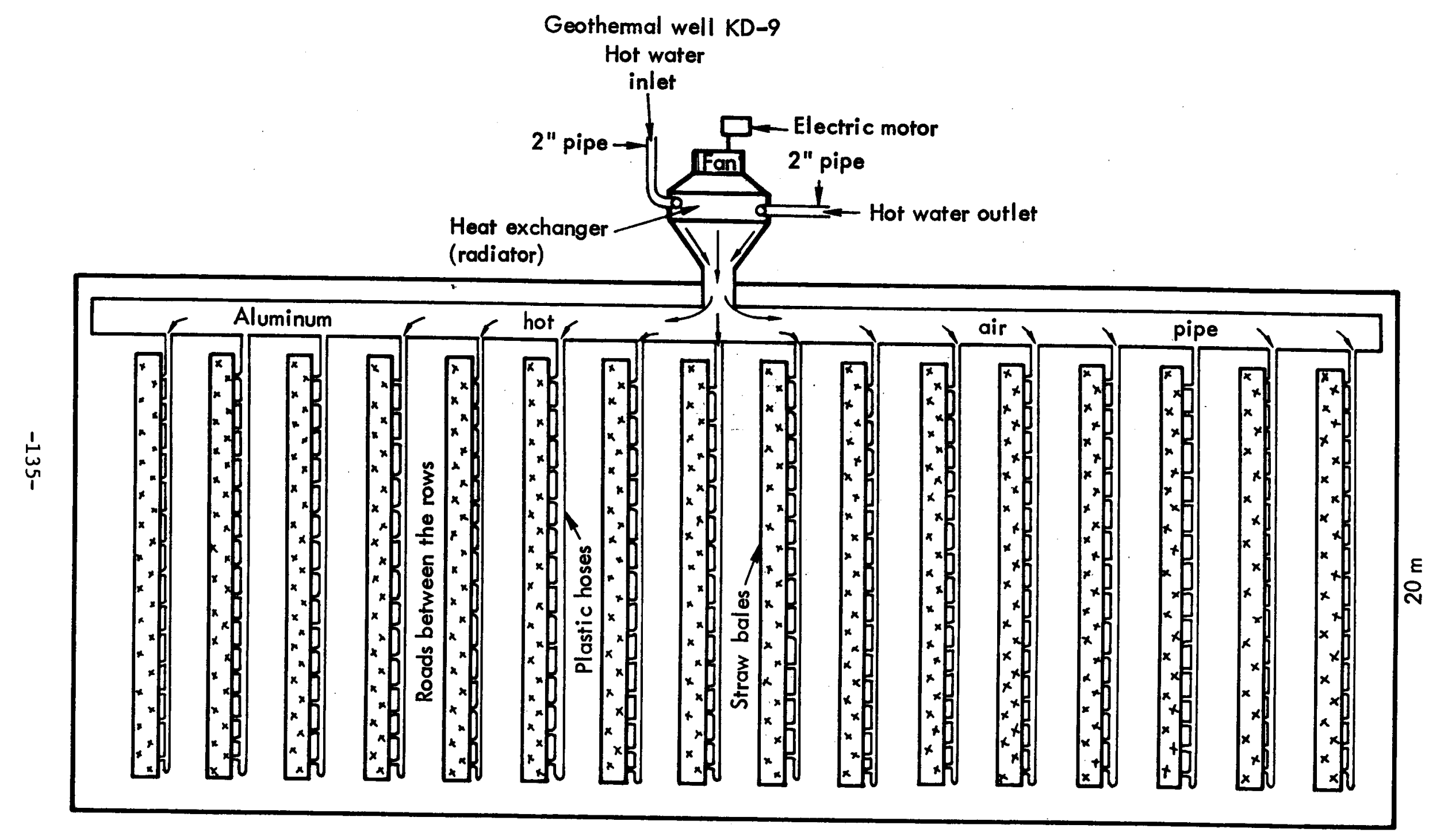

Fig. C-1. Sketch of Kizildere Geothermal Greenhouse. 
openings for the hot air to come out into the greenhouse. During the heating process pressurized hot air by the fan comes into the main hot air pipe, passes into the plastic hoses, comes out of the small openings on the hoses and heats the whole greenhouse equally. Native soil of the greenhouse is very poor and so straw bale rows are used as soll to grow plants on.

\section{Total energy capability associated} with entire application: This $1000 \mathrm{~m}^{2}$ pilot greenhouse heating system uses $8,8 \times 10^{8} \mathrm{kcal}$ of energy for a six months heating period.
Brief Description of Resource being tapped: Kizildere Geothermal field has two reservoirs on top of each other and possibly a third one beneath them. The top reservoir is Miocene limestone. The second reservoir, which is the well used for greenhouse heating ( $\mathrm{KD}-9)$ is drilled in Paleozoic volicanic.

In the center of the reservoir maximum temperature is $207^{\circ} \mathrm{C}$, but temperature reduces away from the center. $\mathrm{KD}-9$ is hot in the center so we1l bottom temperature is $160^{\circ} \mathrm{C}$. At 5.5: atm, well head pressure maximum flow rate is 154 tons of hot water per hour. The matn dissolved solid is $\mathrm{CaCo}_{3}$, like all the other wells of the field. 


\section{Appendix D: Developments in New Zealand ${ }^{\star}$}

GENERAL

Some of us in Taupo this weekend had power cuts while some of the more fortunate ones at this Hotel were enjoying some comfort from geothermal heating. No wonder we eye the 400 tons/hr of hot water from the Wairakei field with a certain longing, wondering whether we will ever see it piped a mere 5 miles to Taupo.

It is of interest to note that neither the N.Z.E.D. Village of 140 houses or the M.W.D./D.S.I.R. Offices are heated by Geothermal Energy and this is an Indication of the lack of real progress in home heating throughout the thermal belt of New Zealand.

Possibly the two maln reasons

are: (a) the doubts re mineral deposition in pipelines and (b) the absence of a suitable Authority or Corporation to develop and encourage the use of such an energy source.

Fortunately; solutions are being developed in respect of mineral deposition and there are encouraging signs in the New Zealand energy field as a result of: (a) the oil crisis and (b) the setting up of the Minis- $\ldots$; try of Energy Resources and the expansion of the Ministry of Works to include the most important role

* By W. B. St11we11 of the development of our natural resources.

In our field, this has now meant that geothermal energy is to be no longer mainly developed for the generation of electrical energy, but is to be used in the best interests of New Zealand's economy. The Ministry of Works \& Development (MWD) is thus able to take the initiative in developing geothermal in the nonelectrical fields while still keeping major power development needs in mind.

I will now cover in more detail non-electrical uses under study or trial. From these examples, it can be seen that in the wet fields of New Zealand developments are unlikely to be along solely non-electrical lines, but more in combination with electrical development or purely as a by product. One of the drawbacks to the development of geothermal for industrial applications in the thermal belt is the comparative lack of suitable materials with the notable exception of the nearby forests. Pumice there is aplenty but this has already been through the processing cycle and is of limited value.

\section{TAUHARA}

Tauhara has been shown to be a remote part of the Wairakei field and 
T.C.

MADEN TETKIK VE ARAMA ENSTITÜSÜ GENEL DIREKTÖRLỨc̈Ü
Bentley:

CODES : Wistern Union S Letter Ea Rudoll Mome-Code-Supl.

Tel : AIETTis - Aukare Pusta Kuturu : 116

\author{
REF No. $-10-262 y \quad 17955$
}

Mr.J. H. Howard

P. 0. Box 808 (L-47)

Livermore, California, 94550

U. S. A.

Dear Sir,

In the First NATO geothermal Energy meeting, which took place in New-Zeland between 29-th April of 1974 and 3-th May of 1974, for informations about Geothermal Energy, it was decided to pub. lish a book about former applications of Geothermal Energy except for electrical purposes in the world.

A report about applications in Kizildére geothermal field, for growing plants in a Greenhouse, prepared by $M r . F . \operatorname{Tan}^{x}$ ) who attended the meeting as the representative of our Institute is submitted to your information in the following pages.

Yours very truly,

Dr. Sadrettin ALPAN

General Director.

x) Ethem Tan, Petroleum Eng.

MS. METU

$/ \mathrm{mb}$ 
is virtually at the back door of Taupo. ROTOKAWA

In this field is sited a major timber and hardboard plant for which there are major expansion plans afoot for 1975 requiring large quantities of process heat.

It is proposed to build a plywood plant which will use approximately 70 kilopounds per hour ( $\mathrm{kph}$ ) of saturated steam at 150 psig as well as using lower grade heat for $10 g$ preheating .

A timber drying and preservation plant is also envisaged and this would require $65 \mathrm{kph}$ of steam at $150 \mathrm{psig.}$ Ultimate requirements could require up to $200 \mathrm{kph}$ of steam.

Heat exchangers will be designed to take both steam and water and there is some flexibility in the temperature of supply, the process requiring total equivalent heat useage.

The MWD in its developmental role is anxious to test a binary cycle pilot plant because of its possible inclusion in future geothermal power development plans. This plant of approximately $10 \mathrm{MW}$ capacity could well supply local power needs for some time.

The situation thus appears ideal for dual development and a feasibility study is due to get under way shortly.

This geothermal field is approximately 5 miles N.E. of Wairakei. Trials have been conducted over recent years aimed at the removal of sub-surface sulphur deposits using the Frasch process. The flow from a nearby geothermal well after mixing with river water is injected into the ground to liquify the sulphur which is then raised to the surface by an air flow.

A flow of $25 \mathrm{kph}$ at $320^{\circ} \mathrm{F}$ is expected to flow $1 \frac{1}{2}$ tons sulphur per hour and the North Islands sulphur requirements, which are at present imported, of 150,000 tons per year could be met if the process is shown to be economic and practical.

As this field could have a total output approaching that of Wairakei it would seem logical to develop this as a power source, with the sulphur recovery as a secondary industry, using heat from the reject end of the scale.

\section{BROADLANDS}

With the removal of a largely proven field from the National Power plan in 1972 (which fact probably continues to surprise many of you present) efforts were directed into investigating the output of Broadlands and other localities as process heat for industries. 
In view of the lack of any large scale N.Z. interests (Timber, Pump and Paper processing already being handled elsewhere) enquiries were made abroad and as a result, Japanese interests are now carrying out a feasibility study into the manufacture of heavy water using Broadlands geothermal energy as a heat source, and an enriched HDO content of the nearby Waikato River.

Should this project go ahead, I believe that it would operate on less than half of the predicted output of this field and again we could have the opportunity of developing it as a joint power and industrial use project. A further interesting development at Broadlands lies in a drying and pelletising plant for lucerne (alfalfa) which is due for commissioning later this year.

Initial requirements are for $14 \mathrm{kph}$ of steam at $150 \mathrm{psi}$ to feed a heat exchanger and supply 50,000 $\mathrm{cmm}$ of air at $350^{\circ} \mathrm{F}$ to process the yield from 650 acres. This could rise to $70 \mathrm{kph}$ with the yield from 3000 acres though more efficient use with full bore discharge could reduce this quantity.

\section{KAWERAU}

Reference has been made at various geothermal conference's to the use of geothermal steam to provide clean steam through heat exchangers in a pulp and paper mill. Claimed to be "the largest industrial user of Geothermal steam in the world, this system has been in operation since 1960 and maximum useage has been $400 \mathrm{kph}$ at $100 \mathrm{psig}$ and $200 \mathrm{psig}$. Mineral deposition in the casings has been somewhat of a problem, but outputs have invariably returned to previous values after reaming out with a light rig.

To provide for additional mill expansion, there is a present further need for $145 \mathrm{kph}$ of geothermal steam which could be increased further in the future.

\section{OTHER USES}

I have made no reference to the use of geothermal energy for air conditioning through absorption cooling which may be seen in a plant at the Rotorua International Hotel. Nor have $I$ made any reference to the considerable amount of research carried out by D.S.I.R. and no doubt you will hear more of this in this session. In conclusion, $I$ believe that although we have all no doubt received a rude shock at the sudden emergency of the energy crisis, it 
can only make us more conscious of the need to use energy more efficiently and will act as a spur to greater interest and effort in developing our geothermal resources for best possible use.

\section{Appendix E: Developments in the Philippines*}

NON-ELECTRICAL APPLICATION OF GEOTHERMAL RESOURCES IN THE PHILIPPINES

\section{Application lists and Geographic site.}

A. Salt-Making at Tiwi, Albay.

Status: Semi-commercial scale.

B. Palay and Grain Drying at Tiwi, Albay.

Status: Experimental model under test.

C. Fish Canning at Tiwi, Albay. Status: Under research stage.

D. Refrigeration at Tiwi, Albay. Status: Under research stage. of 641 feet. Steam is being discharged at a rate of $17,0001 \mathrm{bs} / \mathrm{hr}$ at a well head operating pressure of 75 psig. The steam contains an average of $3.4 \%$ by weight of noncondensible gas composed primarily of $\mathrm{CO}_{2}$. It also contains some 34 parts per million of solids, mostly silica. The well presently supplies steam to a 2.5 kilowatt turbine generator set, the salt-making plant units and the experimental palay dryer. The remaining or unused steam is discharged to the atmosphere Description of Resources being exploited. through a vertical twin cyclone The steam discharge from one of

silencer. the Commission on Volcanology's geothermal exploration holes is being utilized for the above-mentioned research ventures of non-electrical application of geothermal resources. The well, drilled in 1968 , is cased with a 6" diameter pipe to a depth of 450 feet and continues down with an 8" diameter open hole to a total depth

*by Arturo Alcarez

\section{Description of Application.}

A. Salt-Making. The salt plant utilizes a triple effect evaporator. The first effect evaporator is heated by geothermal steam, while the other two make use of the generated steam from the first and second effect evaporators, respectively.

Briefly, the prototype plant involves the following steps in the process of salt production: 
Step 1. Pumping of sea

water. Sea water from a 3-km source at Barrio Putsan, Tiwi, is pumped to a 16,000 gallon concrete storage tank.

Step 2. Filtering and preheating of sea water feed. "From the storage tank, sea water is transferred by gravity to a feed and filter tank utilizing several layers of sand and gravel to remove insoluble materials and other sea water impurities. Then the clear sea water is pumped to a sheli and tube preheater where the feed is preheated to about $160-170^{\circ} \mathrm{F}$ before entering the evaporator.

\section{Step 3. Concentrating sea}

water. Preheated sea water enters the evaporator in a spray pattern and is heated to vigorous boiling by steam from the geothermal drill well until the brine reaches a density of about 20 to 23 degrees Baumé.

Step 4. Removal of calcium sulphate and other impurities. The brine is then drained into settling pans and concentrated further until it reaches 25 degrees Baume and most of the calcium sulphate is precipitated together with other impurities.

Step 5. Crystallization of Grade I Salt (97-98\% NaC1). The clear brine is next led to an open type crystallizer pan, called a "grainer". As in the previous pans, the concentrated brine is further heated by means of submerged tubes through which steam passes through. "From 25 to 29.5 degrees Baume, sodium chloride ( $\mathrm{NaCl}$ ), usually called table salt, crystallizes rapidly on the surface and the grains are collected by means of rakes as they settle at the bottom of the "grainer". The liquor at 30 degrees Baume is drained into another crystallizer to recover Grade II salt (91-95\% NaC1); or collected as "bitterns" which may be used in refrigeration systems, fish preservation; or further processed for recovery of magnesium $(\mathrm{Mg})$ and other salts.

Step 6. Washing and Drying. The NaCl salts raked from the crystallizing pans are washed, drained and then led to a screw type dryer heated by: steam.

\section{B. Palay (Grain) Drying Unit.}

The rotary kiln-type palay drying model consists essentialiy of a stationary closed-end 6" dia. horizontal pipe, $10 \mathrm{ft}$. long, and an inside rotating pipe of 1 "dia. through 'which steam passes. The annual space between the 2 pipes serves as the heating chamber.

The rotating steam-ine is fitted with paddles, spiral feed conductor, and kicker. When the grains are fed into the chamber at one end of the unit, they are picked up by the spiral feed conductor which initiates the 
movement of the grains towards the discharge outlet at the opposite end. The paddles ensure thorough mixing of the palay so that each grain can get in contact with the hot surface of the steam line. As the grains reached the other end, they are caught by the kicker and are discharged.

The inside steam-pipe, which is fitted with universal joints so that it can move independently from the whole set-up, is driven by 1-HP motor. The unit is insulated with asbestos magnesia pipes and cement to avoid unnecessary heat losses. It rests on a concrete foundation to minimize vibration and steam leakage. Likewise, a wooden feed hopper is provided to facilitate handling of palay into the chamber.

With natural steam, the drying rate of palay grains was reduced to about 10 minutes as compared to the rate of 4-8 hours, depending on atmos- pheric condition, in the conventional method using heat of the sun. The unit has a drying capability of 48 cavans of palay in a day's operation.

Methods of Disposal of Steam Fluids. The spent hydrothermal fluid is being disposed through an irrigation cana1. The condensed steam may open new resources of fresh water for irrigation or other purposes in the area.

\section{Cost of Exploitation.}

Expenses being incurred at this stage are being charged under research cost.

Any Regulation of Exploitation. None, since they are purely

research work.

Financing arrangement. Research projects are primarily financed by the National Science Development Board (NSDB). 


\section{Appendix F: Agricultural Applications of Geothermal Energy*}

RATIONALE FOR AGRICULTURAL APPLICATIONS

Agricultural applications of geothermal energy offer an opportunity for efficient use of such energy while at the same time contributing to the solution of other pressing problems of mankind such as the ability to supply an adequate diet to all inhabitants of the earth at reasonable cost and reasonable environmental impact. Alternatives to present day agricultural methods must be considered before conventional energy resources and land resources have become limited in supply and before.costs of production have increased dramatically.

Such changes can only be brought about by new concepts and radical departures from existing methods, not by gradual improvements in established techniques. One of these concepts is the use of geothermal energy in agricultural applications. These should have as their goal the production of food by methods reducing both energy requirements and land requirements.

\section{INTEGRATED SYSTEMS}

An integrated system for geothermal energy use is an assembly of

\footnotetext{
* By: L. Boersma
}

components each chosen for its contribution to efficiency of energy use and food production. Such an assemb1y could include (i) greenhouses, (ii) facilities for converting organic waste from livestock operation into protein, (iii) pure-culture single cell protein production units, (iv) facilities for extracting protein from plant leaves, (v) aquacultural operations to produce livestock feed, (vi) waste water treatment facilities, and (vii) food processing plants (Fig. F-1). Interaction and feedback between components should be considered and the whole system should be designed and operated to maximize operational parameters. Similar integrated systems have been proposed for the use of reject energy from power generating stations (Boersma, 1970; Bea11, 1973). Boersma et a1. (1974) present an analysis of the engineering and economic potential of these systems.

The concept of integrated systems is based on the observation that energy problems, pollution problems, and food-production problems must be solved in concert rather than individually. In such a system, the energy-use efficiency could be greatly increased by arranging energy consuming processes in an orderly cascade of decreasing input-output 
Tx2. Nos.

3-29-77-Goneral Managor

3-29-76-Aeaistont Goneral Managor

3-82-28-Proparty Othicer

3-54-11-Private Branch Exchange

Connecting All Dopartmenti

VIA AIR MAIl
Katpublic of the obilippines

Zational $\$$ Power Corporation

161 Bonifacio Mribe, Fort Area

fHanila
Camez Addaess

"NAPOCOA" MAMLA

P. O. Box 2123

August 5,1974

\author{
Dr. J. H. Howard \\ P. O. Box 808 (I-47) \\ Ifrerwore, California 94550 \\ D. S. A. \\ Dear John:
}

Enclosed please find the draft of our national report on "Non-Electrical Application of Geothermal Resources in the Philippines". I hope it is satisfactory. However, please feel free to edit it in the way you think best and to agree with the format of the final report.

Our study tour was indeed interesting and fruitful. It was most enjoyable being with the members of the tour and meeting colleagies involved in the utilization of 10w and high-energy geotherwal resources.

Do try to include the Philippines if you should travel to this part of the world.

Best wishes and esteem.

\author{
Sincerely yours, \\ Ceivice. \\ ARTURO ALCARAZ \\ Chief, Geotherwal Division
}

Bncl.: No 
temperatures. These systems would also allow recycling of raw materials for more efficient use of agricultural products. In present methods of operation, food is harvested, processed, packaged, delivered, consumed, and eventually excreted. The energy required to go through this cycle is of ten greater than the energy derived from the food itself. The waste of garbage, sewage, packaging, and the energy of disposal are unproductive expenses. This open-ended system of management must be changed into $a$ " closed cycle of food regeneration going from solar heat to human energy without the great losses that now occur. The integrated system for geothermal energy use should not only involve industrial needs. The utility components of the local communtity should be considered as well. For example, a waste-water management system should be a part of the total project. Geothermal energy could be used to speed up the renovation of organic waste and allow the use of the nutrients dissolved in the water for single cell protein production (Fig. F-1).

\section{GEOTHERMAL ENERGY USE PLAN}

Several components which could become part of an integrated food production and processing complex are assembled in Fig. F-1. Note that the

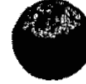
diagram is not produced to show the most desirable arrangement or mix of components. That can only be established upon completion of a detailed engineering and economic analysis. Rather, the diagram is to be used for a discussion of the many opportunities for efficient use of geothermal energy, product recycling, and pollution abatement.

Geothermal energy should be used to satisfy existing and future energy needs in a specific region. The conceptual design phase should therefore start with an inventory of the geothermal resource in terms of magnitude and depletion rate. Since part of the energy needs can best be satisfied by electricity, an assessment should be made of the potential for generation of electric power.

The region where the geothermal energy is to be used for agricultural purposes must be characterized in terms of the questions surrounding its ultimate development potential: what is the climate, (ii) how suitable is the climate for various agricultural enterprises, (iii) what is the potential for industrial development, (iv) where would people live, (v) what are the recreational opportunities, (vi) what markets could be served by the region, (vii) should agriculture be emphasized, (viii) should industry 


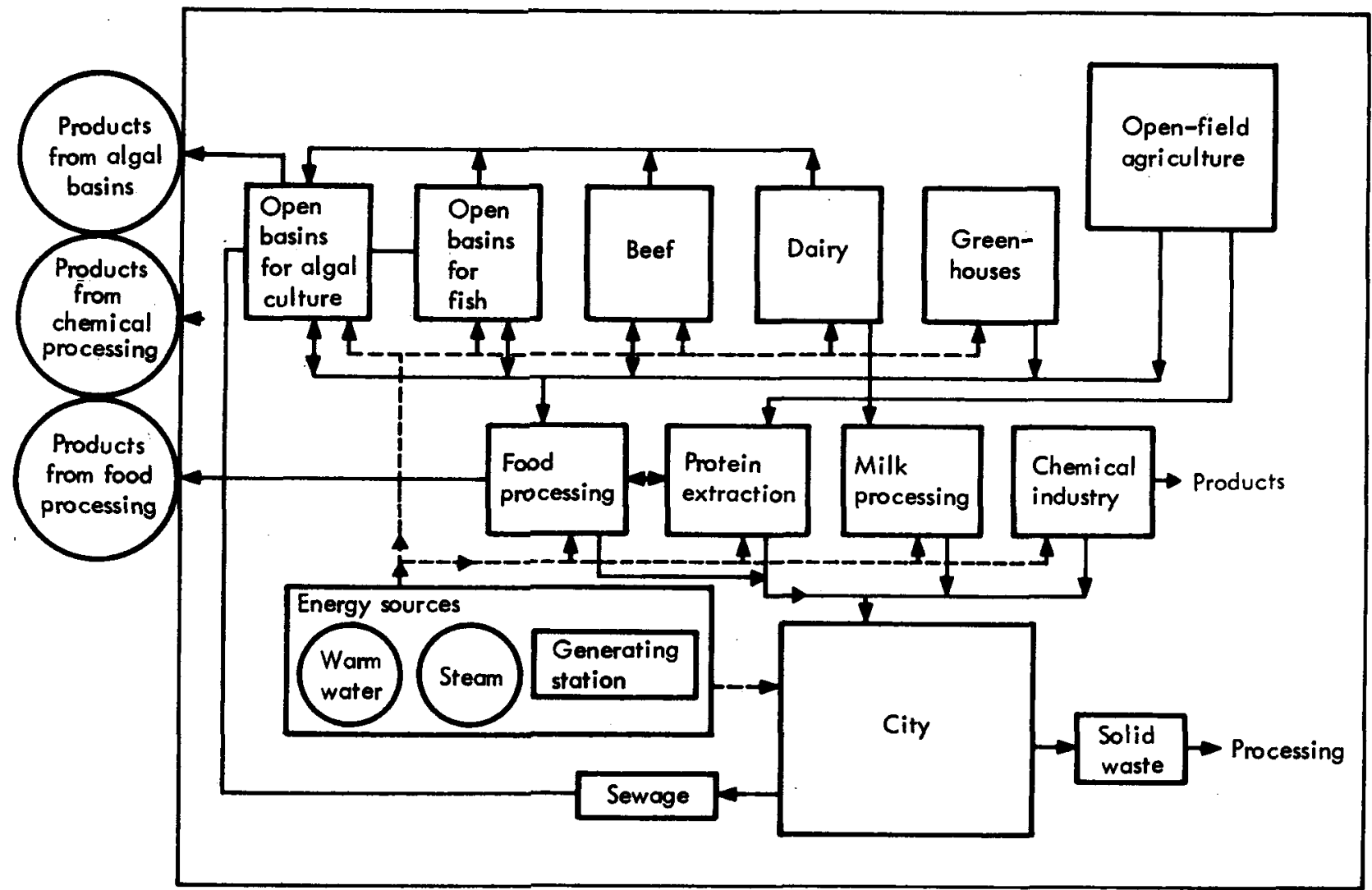

Fig. F-1. Schematic diagram of components of an integrated system for the production of food and fiber, which could derive energy from geothermal sources.

be emphasized. The accumulation of this information would provide guidelines for development.

Each specific application of geothermal energy must be carefully described in terms of the questions of energy requirements and production rates: (i) what temperatures are required for the growth of certain crops, (ii) how are these temperatures best maintained, (iii) what type of Geat exchanger should be used, (iv) what are the energy requirements for the specific climatic conditions encountered.

The next step in the development of a geothermal-energy use plan would be to determine the best assembly of components for the region being considered. Using the Klamath Falls region in Oregon as an example, it might well be decided that this region should emphasize agricultural applications to supply large population centers in California and Washington. This development should include 
chemical-extraction industries as

we11. The mix and size of components should be based on potential market demands and estimates of geotherma1energy resource size. This task should include a detailed analysis of product flows and energy flows within the region and across regional boundaries.

Finally, specific engineering designs must be prepared. These would form the basis for cost estimates and economic analyses. The proposed.systems have not been conceptually developed for any specific region.

\section{SCHEDULE OF TASKS}

Several tasks need to be accomplished to develop the geothermalenergy use plan and bring it to reality. The accomplishment of these tasks should progress from a conceptual design to the construction and operation of a pilot plant.

1. Conceptual design

1.1 Size of geothermal resource

1.2 Climate

1.3 Demographic possibilities

1.4 Possible population size

1.5 Markets

1.6 Possible market developments

2. Description of individual components

2.1 Energy requirements
2.2 Products

\subsection{Production rates}

3. Selection of component mix

3.1 Determine energy needs

3.2 Determine energy flows

3.3 Determine product flows

3.4 Size of individual components

4. Engineering design

4.1 Complete a final engineering design based on the information accumulated.

5. Economic analys is

5.1. The economic analysis must indicate the economic feasibility of the proposed system. Comparisons with other methods of production must be made.

6. Pilot plant

6.1 Design, construct, and operate a pilot plant.

SPECIFIC APPLICATIONS

\section{Single-Cell Protein}

Micro-organisms such as algae provide a vitamin-rich food having high quality protein. The material is referred to as single-cell protein to describe its derivation from organisms each consisting of a single ce11. The name avoids possible unpleasant connotations relative to 
food which might be associated with such terms as "bacterial" or "microbial". Advantages of these organisms are their high protein content, the possibility of growing them during the entire year, and the potential for technological management in a continuous-flow industrial production stream (Soeder and Pabst, 1970). Algae can obtain their nutrients from animal manure or domestic sewage. The use of algae in combination with bacteria is an ideal biological method of reclaiming waste water and recovering potable water. When used in combination with conventional agriculture in totally integrated systems, algae can be used to recycle minerals and thus greatly contribute to the efficient use of energy and capital.

The advantages of algae have been recognized for a long time (Tamiya, 1957; Oswald and Golueke, 1968; Stengel, 1970). Experimental work with these organisms has indicated their production potential. Commercial adaptation of algal culture for protein production has been limited. by the need to maintain the culture medium at about $30^{\circ} \mathrm{C}$ and by the energy requirements for harvesting the organisms. The algal cells are very small, making centrifugation (which is energy intensive) the most efficient harvesting technique. The temperature of the water in which the algal cells grow is one of the most important determinants of production rate and biological stability (Sorokin and Krauss, 1958). Low temperatures prevent algal cells from using available light energy in an efficient manner. Maintaining the basin temperature constant has the additional advantage that it allows the desired species to compete well with less desirable organisms. Recent experiments have shown that very high protein production rates can be obtained with algae using swine manure as a substrate (Boersma et al., 1975). Temperature control of algal basins. could be achieved by pumping high-temperature geothermal water through pipes immersed in the basins used for algal culture. Desirable basin temperatures range from 25 to $35^{\circ} \mathrm{C}$. The spacing and size of the submerged pipes required to supply the necessary energy to the basins depends on climatic conditions and temperature of the heat source.

Production information necessary for an economic analysis of algal agriculture is not available at this time. Until recently, algae were only grown in the laboratory for experimental purposes. They are gradually gaining consideration for mass culture (Soeder and Pabst, 1970). The economic feasibility of growing algae in mass culture is rapidly improving. Protein production appears 
to be economically feasible in heated basins but not in basins without temperature control.

\section{Leaf-Protein Extraction}

The presence of protein in leaves has been recognized since Berzelius first coined the name "protein" and defined the chemical category (Hartley, 1951). Little attention has been paid to ways to extract it for human consumption. It is potentially the most abundant new protein source. It could be particularly useful when processed, for example, as TVP (1.e., "Textured Végetable Protein"). These products are now derived from soybean oil and used as "extenders" in many meat products. The protein is spun into fibers which can be arranged to simulate many products produced by nature.

Many advantages are to be expected from leaf protein extraction. It would provide a more efficient pathway for human protein use than animal agriculture as currently practiced. Land and water resources could be more efficiently used if the objective of farming were to produce leaf proteins rather than grain for animal feed.

Processing plant material for protein extraction involves many steps Including mechanical disintegration of the plant cells, pressing the slurry to séparate juice from fiber, processing cooked the juice which contains the soluble protein and suspended chloroplasts. The juice may be concentrated and dried or it may be fractionated by treatment with heat and solvents. All these processes are energy intensive. Process temperatures range from 50 to $80^{\circ} \mathrm{C}$. Geothermal energy would be a suitable energy source for protein extraction from plants.

It is generally accepted that a growing demand for different forms of protein is to be expected. Leaf protein could satisfy part of this demänd. Geothermal energy is an Ideal energy source for industrialscale leaf-protein extraction. The Industry should be an essential component of an integrated food and fiber producing complex.

\section{Food Processing}

Food processing requires large amounts of energy for cooking, drying, and condensing and large quantities of fresh water for cleaning, processing, and sanitation. Temperature requirements, however, rarely exceed the boiling temperature of water., An industry review identified the following operations in food processing for which geothermal energy might be used:

(1) Preheating of fluids to be (2) Preheating for blancing waters 
(3) Preheating cans for sterilization

(4) Sealing of cans and bottles at 40 to $50^{\circ} \mathrm{C}$

(5) Preheating food and cans in hot filling operations

(6) Preheating of substances in evaporation and condensing

(7) Tower drying

(8) Low-temperature grain drying

(9) Preheating for milk sterilization

(10) Freeze-drying processes Many high temperature operations in food processing require process steam. The steam can of ten be derived from geothermal sources. Food processing would be an essential part of an integrated crop production and processing system.

\section{Aquacu1ture}

Aquaculture is the growing of fish under controlled conditions. Aquaculture has been practiced for centuries but its commercial value has only recently been recognized. The most highly developed aquacultural operations are in Japan.

Many fish species of commercial value have a limited optimumtemperature range. The benefit of temperature control with respect to production capacity is great. Shrimp grow 80 percent faster in water at $27^{\circ} \mathrm{C}$ than in water at $20^{\circ} \mathrm{C}$. The energy required to heat open-air water basins for fish culture would be very large. The cost of energy would be prohibitive if it had to be produced locally for the specific purpose of heating the basins.

However, geothermal water might be advantageously used for this purpose. The basins would be heated by pumping the warm water through submerged pipes. The temperature of this water should be about 35 to $40^{\circ} \mathrm{C}$. Size and spacing of the pipes is determined by climatic conditions and temperature of the warm water.

The greatest potential for the development of aquaculture lies in the use of the fish product for cattle feed. Fish meal has long been an important component of animal feed. Its value became dramatically apparent only a few years ago when the anchovy harvest off the coast of Peru rapidly declined. The ensuing search for substitute protein resulted in a rapid rise in the price of soybeans. Aquaculture would be an important component of an integrated agricultural production scheme.

\section{Greenhouses}

Air temperature, relative humidity, and air circulation are carefully controlled in modern greenhouses. Because of rapidly alternating heating and cooling 
requirements, greenhouses are difficult structures to heat. With current techniques, heating is usually accomplished with radiators heated with steam or hot water. The energy for heating is usually derived from coal, gas, oil, or electricity. Cooling requirements are met by ventilation or ventilation in combination with evaporative cooling pads. Ventilating air is drawn through a watersoaked curtain or pad with the air being cooled by providing energy to evaporate water from the pads.

Geothermal energy can convenient1y be used to provide the energy required for heating greenhouses. The design of the heating system would depend on the temperature of the available geothermal energy resource. If the temperature is sufficiently high, conventional finned-tube heat-exchangers can be used. This temperature should at least be higher than about $50^{\circ} \mathrm{C}$. At lower temperatures the size of the finned-tube-heat-exchanger rapidly increases and a more expensive installation results.

Warming the greenhouse soil can also be accomplished by circulating warm water through a network of underground pipes (Boersma and Rykbost, 1975). The soil is maintained at a desirable temperature and the heat escaping through the soil would be available for warming the greenhouse air. Theoretical considerations and experimental measurements indicate that the heating capacity would not be sufficient to keep the greenhouse air temperature more than a few degrees above the outside air temperature during the night and auxiliary heating would be required. This application has the advantage that it allows a rapid warming of the soil in structures which are not in use during part of the winter. Increasing the soil temperature by this method has been demonstrated to increase production.

\section{Open-Field Soil Warming}

Soil temperature and air temperature are important climatic factors affecting plant growth. The optimum soil temperature varies with plant species and variety. Control of temperature in agricultural activities has been limited primarily to greenhouse horticulture. Several approaches to increasing the soil temperature in the open field have been considered. Geothermal energy offers the potential for open field soil warming by pumping warm water through a network of underground pipes. The resulting temperature distribution depends on the source temperature, air temperature, and depth and spacing of the heat sources. 
The effect of increased soil temperature on crop production has been evaluated in recent experiments (Rykbost, et al., 1974). Several crops have been grown on plots heated with parallel subsurface line-heat sources. The economic feasibility of this production technique was analyzed by comparing production costs directly attributable to soil warming with the value of the increased yield. Several crops were identified which could be profitably produced with soil warming. These were high value crops such as tomatoes or strawberries or crops which could be double cropped as a result of soil warming. Low value crops generally could not be grown economically using this technique. The economic potential of soil warming in the open field could be enhanced by decreasing the capital cost through the use of wider heat source spacings, by selecting crop varieties more responsive to soil warming, or by decreasing the cost of the energy source.

The effect of soil warming on air temperature is very small. The average daily alr temperature cannot be expected to be increased more than about one degree using this technique.

\section{ENERGY REQUIREMENTS IN AGRICULTURE}

The magnitude of energy consumption in agricultural production, although a small percentage of total energy consumption in the United States is significant when compared with other industrial categories. See Table F-1. The impact of energy

Table F-1. Energy inputs for several uses in percent of total U.S. consumption (Heichel, 1974).

\begin{tabular}{lc}
\hline & $\begin{array}{c}\text { Percent of total } \\
\text { Category }\end{array}$ \\
\hline & 25 \\
Transportation & 18 \\
Space heating & 5.7 \\
Iron and steel & 4.8 \\
Petroleum refining & 3.5 \\
Agriculture & 2.2 \\
Paper & 2.1 \\
Petrochemical feedstock & 1.2 \\
Aluminum & 0.8 \\
Ammonia & 0.3 \\
Glass & \\
\hline
\end{tabular}


shortages on food production occurs not only because of limited availability but also as a result of increased cost (Pimentel et al., 1974).

The potential impact of the use of geothermal energy for agricultural applications may be deduced from studies in which the energy flows in agriculture were quantified. Table F-2 shows the total annual per capita energy consumption for food-related activities in the United States. The data apply to the year 1963. The energy required on the farm was only a small part of total agricultural energy needs. Forty-seven percent of the total energy requirement was used. for processing while an additional thirty-one percent was used for food processing in the home. A similar analysis for Australia showed similar results (Anonymous, 1974).

Agricultural applications of geothermal energy may provide one of the tools needed to increase agricultural production above current levels. A recent study (Resources and Man, 1969) promulgated a "rule of 2 " for food-increase goals in the world: a twofold increase by bringing new lands into cultivation, a twofold increase by increasing productivity, and a twofold increase by innovation. The combined effect multiplies these efforts and would result in an eightfold increase in production.

Agricultural application of geothermal energy would contribute to each of these categories. It would allow bringing into cultivation lands not

Table F-2. Total annual per-capita energy consumption for food related activities in the United States during 1963 (Hirst, 1974).

\begin{tabular}{|c|c|c|c|}
\hline \multirow[b]{2}{*}{ Category } & \multirow{2}{*}{$\begin{array}{c}\text { Annual } \\
\text { Consumption } \\
\left(10^{6} \text { Kcal } / \text { person }\right)\end{array}$} & \multicolumn{2}{|c|}{ Percent of total } \\
\hline & & $\begin{array}{l}\text { Food related } \\
\text { energy uses }\end{array}$ & $\begin{array}{c}\text { A11 energy } \\
\text { uses }\end{array}$ \\
\hline $\begin{array}{l}\text { Farm production } \\
\text { Processing }\end{array}$ & 0.30 & 4 & 0.9 \\
\hline $\begin{array}{l}\text { Transportation } \\
\text { In plant }\end{array}$ & $\begin{array}{l}1.16 \\
2.67\end{array}$ & $\begin{array}{l}14 \\
33\end{array}$ & $\begin{array}{l}3.1 \\
7.3\end{array}$ \\
\hline Distribution & & & \\
\hline $\begin{array}{l}\text { Transportation } \\
\text { Trade } \\
\text { Home preparation }\end{array}$ & $\begin{array}{l}0.23 \\
1.31 \\
2.49\end{array}$ & $\begin{array}{r}3 \\
16 \\
31\end{array}$ & $\begin{array}{l}0.7 \\
3.5 \\
6.8\end{array}$ \\
\hline Total & 8.16 & 100 & 22.3 \\
\hline
\end{tabular}


now being used. It would contribute to increasing the productivity of land currently used at a low level of productivity. And it would contribute to increasing productivity by innovation. It is particularly in the last category that geothermal energy offers its greatest potential.

\section{References to Appendix F}

Anonymous. "Energy down on the farm," Rural Research 85 (1974) pp. 4-14.

S. E. Bea11, "Conceptual design of a food complex using waste warm water for heating," J. Env. Qual. 2 (1973) pp. 207-216.

Boersma, L., "Warm water utilization," S. P. Mathur and R. Stewart (eds.), Proc. Conf. on Beneficial Uses of Thermal Discharges. (New York State Dept. of Environmental Conservation, Albany, N.Y. 1970) pp. 74-107.

Boersma, L., L. R. Davis, G. M. Reistad, J. C. Ringle, and W. E. Schmisseur, A Systems Analysis of the Economic Utilization of Warm Water Discharge from Power Generating Stations. (Bulletin No. 48. Engineering Experiment Station, Oregon State University, Corvallis, Oregon, 1974).

Boersma, L. and K. A. Rykbost, "Soil warming with power plant waste heat in greenhouses." Hort. Science, 10 (1975) pp. 28-30.

Boersma, L., E. W. R. Barlow, J. R. Miner, H. K. Phinney, and J. E. Oldfield, "Protein production rates by algae using swine manure as a substrate," in Proc. Cornel1 Conf. Energy, Agriculture, and Waste Management, April 16-19, 1975. Syracuse, New York, 1975 (in press).

Hartley, H., "Origin of the word 'protein'." Nature, (London) 168 (1951) p. 244 .

Heiche1, G. H., "Energy needs and food yields," Technology Review 76 (1974) PP. 2-9.

Hirst, Eric, "Food related energy requirements," Science 184 (1974) pp 134-138.

Meadows, D. H., D. L. Meadows, J. Randers, and W. W. Behrens, The Limits of Growth. (Potamac Associates, Washington, D.C., 1972)

Oswald, W. J. and C. G. Golueke, "Large-scale Production of Algae," in R. I. Mateles and S. R. Tannenbaum (eds.), Single Cel1 Protein. (Massachusetts Institute of Technology Press, Cambridge, Mass., 1968) pp. 271-301.

Pimental, D., L. E. Hurd, A. C. Bellotti, M. J. Forster, I. N. Oka, 0. D. Sholes, and R. J. Whitman, "Food production and the energy crisis," Science 182 (1974) pp. 443-449. 
Resources and Man, Committee on Resources and Man, National Academy of Science and National Research Council, (San Francisco, W. H. Freeman and Company, 1969).

Rylkbost, K. A., I. Boersma, H. J. Mack, and W. E. Schmisseur, Crop Response to Warming Solls above their Natural Temperatures, Agricultural Experiment Station, Oregon State University, Corvallis, Special Report 385 (1974).

Soeder, C. J. and W. Pabst, "Gesichtspunkte fur die Verwendung von Mikroalgen in der Ernahrung von Mensch, und Tier," Ber. Dtsch. Bot. Ges. 83 (1970) pp. 607-625.

Sorokin, C. and R. W. Krauss, "The effects of light intensity on the growth rates of green algae," Plant Physiol. 33 (1958) pp. 109-113.

Stenge1, E., "Anlagen und Verfahren, der Technischen Algenmassen Produktion." Ber. Dtsch. Bot. Ges. 83 (1970) pp. 589-606.

Tamiya, H., "Mass culture of algae," Ann. Rev. Plant Physiol. 8 (1957) pp. 309-334. 


\section{Appendix G: Index of Contributors to This Report and Other Workers in the Field of Geothermal Energy}

\author{
PRINCIPAL CONTRIBUTORS TO THIS REPORT \\ The following list contains the \\ names and addresses of the principal \\ contributors to this report:
}

\author{
A. Alcarez, Chief \\ Geothermal Division \\ National Power Corporation \\ Manila, Philippines \\ Assoc. Prof. Dr. Sadrettin Alpan \\ General Director of the Mineral \\ Research and Exploration \\ Institute of Turkey \\ Maden Tetkik ve Arama Enstitusu \\ Ankara, Turkey \\ Dr. Enrico Barbier \\ Internationa1 Institute for \\ Geothermal Research \\ Lugarno Pacinotti 55 \\ 56100 Pisa, Italy \\ Christopher C. Barton \\ 359 Prospect Street \\ Norwood, Massachusetts 02062 \\ Prof. Gunnar Bodvarsson \\ 1377 N.W. Alta Vista Drive \\ Corvallis, Oregon 97330 \\ Prof. L. Boersma \\ Dept. of Soll Sclence \\ Oregon State University \\ Corvallis, Oregon 97331 \\ G. E. Brandvold \#5710 \\ Sandia Laboratories \\ Sandia Corporation \\ Albuquerque, New Mexico 87115
}

Dr. James C. Bresee

Div. of Geothermal Research

U.S. Energy Research and

Development Administration

20 Massachusetts Ave, N.W.

Washington, D.C. 20545

\section{J. J. Cohen}

University of California

Lawrence Livermore Laboratory

P. 0. Box 808

I.ivermore, California 94550

N. B. Crow

University of California

Lawrence Livermore Laboratory

P. O. Box $808 \quad \mathrm{~L}-20$

Livermore, California 94550

Dr. Mario Fanel1i

International Institute for Geothermal Research

Lugarno Pacinotti 55

56100 Pisa, Italy

Jorge Guiza

Head Geothermal Resources Dept.

Comision Federal de Electricidad

Rodano 14, 9th Floor

Mexico 5, D.F. Mexico

Dr. J. H. Howard

University of California

Lawrence Livermore Laboratory

P. 0. Box 808 L-505

Livermore, California 94550

Alan M. Jessop, Director

Geothermal Studies Section

Seismology Division

Department of Energy, Mines and Research

1 Observatory Circle, Ottawa, Canada 
Dr. Oskar Kappelmeyer

Geological Survey Germany,

3 Hannover 23

P. 0. Box 230153

West Germany

Dr. Jay F. Kunze, Manager

Reactor Technology Branch and Geothermal Projects

Aerojet Nuclear, Nat1. Testing Station

Idaho Fal1s, Idaho 83401

Dr. B. C. Marshal1

Sandia Laboratories

Sandia Corporation

Albuquerque, New Mexico 87115

Dr. William E. Ogle

3801 West 44th Avenue

Anchorage, Alaska 99503

Kar1 Ragnars

National Energy Authority

Laugavegor 116

Reykjavik, Iceland

Dr. Gordon M. Reistad

Asst. Professor

Dept. of Mechanical Engineering

Oregon State University

Corvallis, Oregon 97331

\author{
M. Paul Sangnier \\ DGRST \\ Ministry. for Industrial and \\ Scientific Development \\ 35 Rue Saint-Dominique \\ 75007 Paris, France \\ W. Basil Stilwell \\ Geotherma1 Engineer \\ New Zealand Ministry of Works \\ Wairakei \\ Private Bag Taupo \\ New Zealand \\ Frank Studt, Head \\ Science and Industry Division \\ Dept. of Scientific and Industrial \\ Research \\ Private Bag, Wellington \\ New Zealand
}

Ethem Tan

Petroleum Engineer

Minera1 Research \& Exploration

Institute of Turkey

Ankara, Turkey

Sverrir Thorhallson

National - Energy Authority

Reykjavik, Iceland

Prof. Ezio Tongiorg1, Director

International. Institute for

Geothermal Research

56100 Pisa, Lungarno Pacinotti, 55

Italy

Ms. K. B. Tonnesson

University of North Carolina

229 Wilson Hall

Chapel Hill, NC 27514

Dr.D. F. Towse

University of California

Lawrence Livermore Laboratory

P. 0. Box 808

Livermore, California 94550

Dr. Louis B. Werner

Geothermal Project Manager

U.S.E.R.D.A.

20 Massachusetts Ave, N.W.

Washington, D.C. 20545

OTHER WORKERS IN THE FIELD OF GEOTHERMAL ENERGY

The following list includes

persons who have shown a continuing

interest in nonelectrical applications

of geothermal resources.

Ismet Akil, Head

Geothermal Division

Petamina Jakarta, Indonesia

David N. Andersón

State of California

Division of $0 i 1$ and Gas

14169 th Street

Sacramento, California 95814 
Prof. R. C. Axtmann

Princeton University

Department of Chemical Engineering

Princeton, New Jersey 08540

Kenzo Baba

Chief of Exploration Section

Geophysics Department

Geological Survey of Japan

135 Hisamoto

Kawaski-Shi

Takatsu-Ku, Japan

Dr. J. Barnea

Resources and Transport Division

United Nations, New York 10017

Mr. Laurence 0 . Beaulaurier

Program Supervisor, Advanced Power

Cycles, Advanced Conversion Systems

Scientific Development

Bechtel Corporation

P. 0. Box 3965

San Francisco, California 94119

C. H. Bloomster

Geothermal Program

Battelle - Pacific Northwest Laboratory

P. O. Box 999

Richland, Washington 99352

Pietro Ceron, Manager

ENEL Geothermal Research Center

56400 Pisa

Viole Giov. Sisario 56

Italy

Mr. Allen L. Clark, Chief

Office of Resource Analysis

U.S. Geological Survey

National Center - Mail Stop 920

12201 Sunrise Valley Drive

Reston, Virginia 22092

Dr. James B. Combs

Asst. Professor Geophysics

Department of Earth Sciences

University of California, Riverside

Riverside, California 92502
Richie B. Corye11, Program Manager Advance Energy Research \& Technology National Science Foundation 1800 G Street, N.W.

Washington, D. C. 20550

C. G. Culver

Oregon Institute Technology

Klamath Falls, Oregon 97601

Dr. Georg Delisle

Scientific Staff Member

Federal Institute for Soil Research

Hannover, Federal Republic of Germany

H. Djajadi

Director of Vulcanology

Geological Survey of Indonesia

Bernardo Dominquez

Comision Federal de Electricidad

Lusto Serra y Herreros 2098

Mexicali B.C. Mexico

Albert J. Ellis, Director

Chemistry Division, DSIR

Petone, New Zealand

W. J. Elzinga

Directorate of NATO Affairs

Ministry of Foreign Affairs

The Hague

Netherlands

Giancarlo Facca

Phillips Petroleum Co.

1023 Timothy Lane

Lafayette, California 94549

M. Kenneth Fulcher

Regional Planning officer

U.S. Bureau of Reclamation

P. 0. Box 427

Boulder City, Nevada

S. A. Gitterman

Senior Advisor - Technology

Central Mortgage \& Housing Corporation

Head Office

Ottawa, Ont., Canada 
Panayiotis E. Gournaris

Director for Geothermal Energy

Pub1ic Power Corporation

Athens, Greece

Dr. Ralph Haenel

Niedersachsisches Landesamt

3 Hannover - Buchholz

Stilleweg 2

West Germany

F. Allen Harris

Special Assistant to the Administrator Environmenta1, Protection Agency

Room 1025A East Tower A-100

401 M Street, S.W.

Washington, D.C. 20460

F. S. M. Hodsol1

Special Asst. to the U.S.

Representative to CCMS

The White House

722 Jackson Place, NW

Washington, D. C. 2006

C. D. Hornburg

DSS Engineers, Inc.

7483 Northwest

4 th Street

Ft. Lauderdale, Florida 33317

Dana E. Kilgore

U.S. Energy Research Development Administration

1333 Broadway

Oakland, California 94612

Robin Kingston

Senior Partner

Kingston, Reynolds, Thom and Allardice

44 Wakefield Street

P. O. Bóx 5348

Auckland, New Zealand

Dr. George A. Kolstad

Senior Physicist

Division of Physical Research

UU.S.E.R.D.A.

Washington, D. C. 20545
Emile Krieps

Secretary of sitate

Ministry of Interior

Luxembourg, Belgium

Stanley S. Larsen

Engineer

Bureau of Reclamation

Dept. of Interior Bidg., Room 7451

Washington, D. C.

Jacques $L$. Lavigne

Chief, Service Geothermic

Bureau de Recherches Geologies et Ninieres

вP $60009-45018$ Orleans

Cedex, France

Dr. G. W. Leonard, Head

Propulsión Devélopment Dept.

Naval Weapons Center, Code 45

China Lake, California 93555

Fred Longyear

CSL Assoclates

555 Capitol Mal1, Suite 445

Sacramento, California 95814

J. : W. Lund

Oregon Institute Technology

Klamath Falls, Oregon 97601

Dr.: Richard N. Lyon

Technical Director of Reactor Div. Oak Ridge National Laboratory

P. 0. Box Y

Oak Ridge, Tennessee 37830

W. A. J. Mahon

Dept. of Scientific and Industrial

Research, Chemistry Division

c/o Ministry of Works

Private Bag, Taupo

New Zealand

Alfredo Simoes Mendes

Director of Geophysical Services

National Meteorological Service

R. Saraiva Carvalho 2

Llsbon, Portugal 
Sergio Mercado

Geothermal Chemistry Head office

Comision Federal de Electricidad

Box 51990

Mexico 5, D.F.

Prof. Frank G. Miller, Chairman

Dept. of Petroleum Engineering

Stanford University

Stanford, California

Yoshikazu Minohara, Manager

Agri-electrification Dept.

1646 Abiko

Abiko City

Chiba, Tapan

Kenneth F. Mirk

Project Engineer

Lawrence Berkeley Laboratory

Berkeley, California

R. D. Mitchel1

Planning Director

County of Imperial

940 Main Street

E1 Centro, California 92243

Dr. L. J. Patrick Muffler

Coordinator

Geotherma1 Research Program

U.S. Geological Survey

345 Middlefield Road

Menlo Park, CA 94025

Jean Pierre Munier-Jolain

Operations Manager

EURAFREP

64 Rue du Ranelagh

Paris, France

Dr. Manuel Nathenson

U.S. Geological Survey

345 Middlefield Road

Menlo Park, California 94025

Dr. C. Otte

Union Oil Company of California

Union Oil Center

Los Angeles, California 90017
D. H. Quinsey

Advisor, Environment \&

International Affairs

Dept. of Energy, Mines \& Resources

588 Booth Street

Ottawa, Ont., Canada

K. F. Seal

Project Manager

Colombo Plan Bilateral \& Geothermal

Project

Geothermal Energy New Zealand Ltd.

P. 0. Box 5271

Auckland, New Zealand

Dr. Andre C. Simonpietri

Counselor for Scientific Affairs

and U.S.E.R.D.A. Scientific

Representative

American Embassy, Mexico City

Mexico

c/o Dept. of State

Washington, D. C. 20521

Mr. Morris Skalka

Div. of Geothermal Research

U.S. Energy Research and Development 1800 G Street

Washington, D. C. 20545

Morton C. Smith

Group Leader, Q-22 Division

Los Alamos Scientific Laboratory

University of California

P. 0. Box 1663

Los Alamos, New Mexico 87544

J. G. Souther

Research Geologist

Geological Survey of Canada

$100 \mathrm{~W}$. Pender Street

Vancouver, B. C. Canada

Dr. Emilo Steffanel1i

Computation Center

University of Pisa

Pisa, Italy

Donald H. Stewart

Mgr. Geothermal Programs

Battelle Northwest

Richland, Washington 99352 
J. Suyama

Geological Survey of Japan

135 . Hisamoto

Kawasaki-shi

Takatsü-ku, Japan

L. S. Svanevik

Oregon Institute Technology

Klamath Falls, Oregon 9.7601

A. Trisulo

Director of Exploration and Production

Pertamina

Indonesia

Hon. Al U11man, Chairman

House of Ways $\&$ :Means Committee U.S. House of Representatives 2410 Rayburn House office B1dg. Washington, D. C. 20515

Professor Gary Underhill Dept. of Mechanical Engineering University of Texas at Austin Austin, Texas $\mathbf{7 8 7 1 2}$

Mr. Giuseppe Valentini

Directorate for Research and

Development Policy

Directorate Genera1 XII

The Commission of the European

Communities

Rue De La Loi 200

1040 Brusse1s.
Benjamin S. Valiente

Director Ejecutivo

Comision Ejecutivo Hydroelectrica Deil Rio Lempa

9A. C. Pte 950

E1 Salvador

J. Wautrequin

Charge de Recherches

Ministere de la Politique Scientifique

8 Rue de la Sclence

1040 Bruxelles

Mr. Ed Wehlage

10707 E. Orange Drive

Whittier, California 90606

Prof. Paul A. Witherspoon

Professor of Geological Engineering

University of California

Lawrence Berkeley Laboratory

Berkeley, California. 94720

Ing. Samue1 Paredes Zarate

Superintendente, General Planta

Geotermoelectrica

Cerro Prieto

Comision. Federal de Electrididad

Avenida Cairo \#317 Frac

Villa Fontana

Mexicali, Baja, California 